\title{
The Kingdom of Württemberg and the Making of Germany, 1815-1871.
}

\author{
Bodie Alexander Ashton \\ School of History and Politics \\ Discipline of History \\ The University of Adelaide
}

Submitted for the postgraduate qualification of Doctor of Philosophy (History) May 2014 

For

Kevin and Ric;

and for

June, Malcolm and Kristian. 



\section{Contents}

Abstract vii

$\begin{array}{ll}\text { Acknowledgements } & \text { ix }\end{array}$

List of Abbreviations $\quad$ xi

Notes $\quad$ xiii

$\begin{array}{ll}\text { Introduction } & 15\end{array}$

Chapter 1

States and Nation in the Late Eighteenth and Early Nineteenth Century

Chapter 2

Stuttgart and Vienna before 1848

Chapter 3

The Kingdom of Württemberg and Early Kleindeutschland

Chapter 4

Independence and South German Particularism, 1815-1848

The Years of Prophecy and Change, 1848-1849

Counterrevolution, Reaction and Reappraisals, 1850-1859

Chapter 7

Six Years of Autumn: 1860-1866

The Unification of Germany, 1866-1871

Bibliography 



\begin{abstract}
THE TRADITIONAL DISCOURSE of the German unification maintains that it was the German great powers - Austria and Prussia - that controlled German destiny, yet for much of this period Germany was divided into some thirty-eight states, each of which possessed their own institutions and traditions. In explaining the formation of Germany, the orthodox view holds that these so-called Mittel-and Kleinstaaten existed largely at the whim of either Vienna or Berlin, and their policies, in turn, were dictated or shaped by these two power centres. According to this reading of German history, a bipolar sociopolitical structure existed, whereby the Mittelstaaten would declare their allegiances to either the Habsburg or Hohenzollern crowns.

The present work rejects this model of German history, through the use of the case study of the southwestern Kingdom of Württemberg. It demonstrates that Württemberg's state government was dynamic and fully in control of its own policy-making throughout most of the nineteenth century. While it did often align itself with Vienna, it did so for pragmatic reasons of self interest; sometimes, it would forsake that alignment in favour of ties with Prussia, or its neighbouring Mittelstaaten, or even France, if it felt that such ties were in the state's best interests. Keenly involved in the national question, successive governments and monarchs in Stuttgart manoeuvred the country so as to gain the greatest advantage. These manoeuvres included decades-long attempts by Stuttgart, in conjunction with state ministers in Munich, Karlsruhe, Darmstadt, and sometimes Dresden, Kassel, and Hanover, to unite the smaller German states to form a southern 'bloc' (the so-called 'Third Germany') against the aspirations of Austrian or Prussian hegemony in the German hinterland.

This thesis demonstrates that the shape of German unification was not inevitable, and was in fact to a great extent driven by the particularist desires of the Mittelstaaten, rather than the great powers. The eventual Reichsgründung of January 1871 was merely the final step in a long series of negotiations, diplomatic manoeuvres, and subterfuge, with Württemberg playing a vital, regional role.
\end{abstract}





\section{ACKNOWLEDGEMENTS}

THIS THESIS WAS undertaken at the University of Adelaide, and I wish to acknowledge the assistance of the staff and academics in the School of History and Politics of that institution. I would like to single out the late Associate Professor Fredric S. Zuckermann, who was my principal supervisor when I began, and was always the source of greatest academic inspiration, throughout my undergraduate as well as my postgraduate years. Ric is deeply missed by all of us. I cannot express enough thanks for the support of my complete supervisory panel of Professor Robin Prior and Doctor Gareth Pritchard; sitting in an ancient chair, drinking coffee and chatting with Robin about any manner of subjects (both related to the thesis and otherwise) has been one of the most memorable experiences of this candidature, and any student would be lucky to have either of these excellent historians as a supervisor. The support of a succession of postgraduate coordinators and heads of discipline (including, but not limited to, Tom Buchanan, Lisa Mansfield, Claire Walker, Rob Foster, and Vesna Drapac), not to mention the School manager, Greta Larsen, is also greatly appreciated. I would also like to thank the staff at the Barr Smith Library, particularly Margaret Hosking, Maria Albanese and Margaret Galbraith, for their almost superhuman efforts to supply me with hard-to-find books and resources, and for somehow keeping me out of trouble with my overdue loans.

The archival research would have been heavily curtailed if it wasn't for the financial assistance that came from two grants: one, supplied by the Bupa Group in conjunction with the University of Adelaide's Development and Alumni department, and another, which was awarded by the (surprisingly unisex) Australian Federation of University Women (South Australia). Once in Germany, research was conducted at several archives. The assistance provided by many of the archival staff was prodigious. In particular, I would like to give my greatest thanks to the following: Dr. Gerhard Keiper of the Politisches Archiv des Auswärtigen Amts, Dr. Ulrich Kober of the Geheime Staatsarchiv Preußischer Kulturbesitz, Franz Göttlicher from the Bundesarchiv (all in Berlin); Dr. Thomas Fritz, Judith Bolsinger, Anja Stefanidis, Johannes Renz, Irene Kremser, and Archivdirektorin Dr. Nicole Bickhoff, all from the Hauptstaatsarchiv Stuttgart; Dr. Klaus-Dieter Rack of the Hessisches Staatsarchiv Darmstadt; and Karla Rommel of the Stadtarchiv Esslingen.

I can only express my profoundest gratitude to all my family, particularly my parents, who have given an enormous amount of time, effort and support. This work would never have been possible without them, and I owe them a debt I can never repay. In Germany, I was accompanied by my wonderful travelling companions, Kristian Ashton, Courtney Jameson and Ralph Edele. I have also benefitted from some truly extraordinary friends and colleagues who have willingly become a veritable army of proofreaders. In particularly, I'd like to single out the efforts of Kylie Galbraith, Daniel Ashdown, Hilary Jane Locke, Thomas A. Mackay, William Prescott, Justin Madden, Matilda Handsley-Davis and Kyrie Fuss. Each of these is a fine historian in his or her own right, and I dearly hope I have the opportunity to return the favour one day. Needless to say, any errors in this document are produced in spite of their best efforts. As any Ph.D. student knows, writing can be a fairly itinerant process, and I would like to offer my thanks in particular to Daniel Freer and Ian Callahan, who always provided a great and comfortable writing environment away from my office (whether they realised that that's what they were doing or not!)

Finally, I would like to acknowledge the assistance of Tosca, Miranda, Phoebe, Tomsk and Holunderle, all of whom decided at various points during the thesis-writing process that I'd far prefer to tickle their tummies than type another few thousand words. 



\title{
LIST OF ABBREVIATIONS
}

\author{
BArch. Bundesarchiv Berlin-Lichterfelde, Berlin \\ fl. \\ Gulden or Florin; Württemberg unit of currency \\ FO \\ Foreign Office, London \\ GStAPK. Geheimes Staatsarchiv Preußischer Kulturbesitz, Berlin \\ GlaB. Generallandesarchiv Baden, Karlsruhe \\ Hes.StAD. Hessisches Staatsarchiv Darmstadt, Darmstadt \\ PAdAA. Politisches Archiv des Auswärtigen Amts, Berlin \\ StadtAE. Stadtarchiv Esslingen, Esslingen \\ WVLG. Württembergische Vierteljahrshefte für Landesgeschichte \\ (en. Württemberg Quarterly Journal of State History) \\ ZWLG. Zeitschrift für Württembergische Landesgeschichte \\ (en. Journal of Württemberg State History)
}

\section{DECLARATION}

I CERTIFY THAT this work contains no material which has been accepted for the award of any other degree or diploma in any university or other tertiary institution in my name and, to the best of my knowledge and belief, contains no material previously published or written by another person, except where due reference has been made in the text. In addition, I certify that no part of this work will, in the future, be used in a submission in my name, for any other degree or diploma in any university or other tertiary institution without the prior approval of the University of Adelaide and where applicable, any partner institution responsible for the joint-award of this degree.

I give consent to this copy of my thesis, when deposited in the University Library, being made available for loan and photocopying, subject to the provisions of the Copyright Act 1968.

I also give permission for the digital version of my thesis to be made available on the web, via the University's digital research repository, the Library catalogue and also through web search engines, unless permission has been granted by the University to restrict access for a period of time. 



\section{NOTES}

GERMAN IS A logical and relatively easy language to learn, speak, and write. It is, however, not as easy to integrate it into an English-language thesis. Adjectives change their suffixes depending on what grammatical case the sentence takes. For example, the newspaper Schwäbischer Merkur could, in fact, be written as Schwäbischen Merkur or Schwäbischem Merkur, depending on whether it appears as the subject, direct object, or indirect object in a sentence. If preceded by its definite article (der), it would also be written as der Schwäbische Merkur. This, naturally, can become confusing, since the bulk of this text is written in English. For the ease of reading, this thesis will display such titles, regardless of what position they appear in a sentence or whether they are preceded by a definite article, as though they are in nominative case without article. Hence, Schwäbischer Merkur, Württembergisches Heer, or Schwäbische Kronik.

Where possible, footnote references and index entries include the noble rank held by many of the prominent figures in the story of the German unification. So, for example, Karl von Varnbüler will be referred to as a baron (Freiherr). In a very few cases, however, some ranks change over the course of the years studied. Otto von Bismarck, for instance, was at various points a count (Graf), a duke (Herzog), and a non-hereditary prince (Fürst). For ease of reference, instead of constantly altering Bismarck's title, he is referred to throughout this work as a count, as this is the rank he held throughout the majority of his time in power that is pertinent to this work (1865-1871). Similarly, while his surname was technically "BismarckSchönhausen", the Prussian chancellor is almost universally known as "Bismarck"; this is also reflected in footnotes. Kings, regents, princes, and dukes are listed under dynastic surnames. Hence, Grand Duke Leopold of Baden is listed under "Zähringen", while the Prussian kings appear under the name "Hohenzollern."

This work also uses a number of contemporary newspaper sources. In many cases, presumably depending on the copy editor or journalists working on a given day, title formats and other details often altered on an issue-by-issue basis. Thus, the Württemberg newspaper whose title translates as "State Gazette" appears within the same year, month or week, as Staats-Anzeiger für Württemberg, Staatsanzeiger für Württemberg, or, simply, Staats-Anzeiger or Staatsanzeiger. Sometimes, the issue number is listed along with the date. Other times, it is not. For the purposes of clarity, this work will commonly refer to this particular paper as the Staats-Anzeiger für Württemberg, regardless of the titular flourish of that particular issue. Otherwise, details will be provided when they are available. Therefore, if the masthead included an issue number, that will be listed in the footnotes. If the issue number was absent, it will similarly be absent from the footnotes. Otherwise, spellings appear as they do in the original source. Hence, the German word 'defence' (Verteidigung in modern German spelling) may be rendered in the archaic Vertheidigung, just as Rat (advice, or council) may appear as Rath. 



\section{INTRODUCTION}

IN THE SOUTHWEST of what is now Germany lies a federal state called BadenWürttemberg. Centred around the state capital, Stuttgart, Baden-Württemberg is a great financial and industrial centre of the Federal Republic of Germany. The emergence of its influence is, however, a relatively new development. Indeed, its territory is a modern amalgam of two separate states - Baden, and Württemberg - haphazardly mashed together by the occupying powers in the immediate aftermath of the Second World War. Before this, both had been separate under the federal umbrella of the National Socialist state and, earlier, had maintained a measure of autonomy under both the Weimar system of democratic federalism, and the imperial oversight of the German Empire. Prior even to this, both were independent states with their own royal houses, laws, currencies, foreign policies, and domestic taxes. Of the two, the largest and more geopolitically important was Württemberg, and its experiences during the process that would lead to the creation of the German Empire are the subject of the present work.

Württemberg had begun the century with lofty ambitions that were invariably tempered with stark reality. It had been a backwater duchy under an unpopular royal scion, Duke Friedrich II, until 1806, when Friedrich's diplomatic machinations with the emperor of the French, Napoleon Bonaparte, had won him expanded territories and an elevation to kingship. The relationship was not without cost; Friedrich remained unpopular among his subjects, largely due to the extensive concessions made to the French, and the newly-minted kingdom became merely another client state to in Napoleon's German buffer zone. ${ }^{1}$ With the defeat of France and the reallocation of German territories in the aftermath of the abortive Hundred Days campaign, Württemberg's position as a medium-sized monarchy

\footnotetext{
${ }^{1}$ Adam Zamoyski, Rites of Peace: The Fall of Napoleon and the Congress of Vienna (New York: HarperCollins, 2007), 21; a good account of the changing fortunes of the small states (including Württemberg) can also be found in Enno E. Kraehe, Metternich's German Policy, Vol.1: The Contest with Napoleon, 1799-1814 (Princeton: Princeton University Press, 1963), passim.
} 
and a southern power of some influence was reaffirmed, with its foreign and domestic policy no longer subject to foreign oversight. Just five and a half decades later, Württemberg surrendered its sovereign rights as an independent kingdom, and became a federated state of the new, Berlin-led German Empire. This act was not, as is often suggested, the result of a hostile takeover by aggressive Prussian manoeuvring. Nor was it the consequence of an inexorable course of universal, romantic German nationalism. Rather, Württemberg's membership in a united German nation-state was the conclusion to a complex series of largely unpredictable social and political circumstances.

The foundation of the Empire in 1871, known as the Reichsgründung, became for Württemberg the most likely outcome, given the events that had come to pass since the Napoleonic Wars. It was by no means the only possible outcome. Nor was it always the most likely outcome. Instead, a succession of Württemberg leaders, some more astute than others, pursued a number of models of codependent and independent existence. Their choice of model at any given time was predicated upon foreign affairs, domestic economic stability, and the general mood of the Württemberg public. Despite its role as a "middlestate" (Mittelstaat) without a significant amount of geopolitical, economic, or military power, Württemberg was at all junctures in control of its own destiny, and never subject to the whim of material coercion, in the form of Prussian militarism, or more ethereal forces, such as nationalist romanticism. The decision to unite with Germany was one taken by a sober government after several decades of logical reasoning and negotiation.

The present work deals fundamentally with the question of identity. In order to understand the role of Württemberg in the German unification (and the role of the German Question in Württemberg politics and society), we must examine a number of intertwining conceptions of self. What did being a Württemberger mean to Württembergers, or other Germans? What did being German mean to the same? 


\section{Nationalism, State-Building, and Germany.}

"The nation is a concept of unity", writes Michael Hughes in his influential overview of German nationalism. ${ }^{2}$ For all the simplicity of this statement, it is probably this discussion's most useful starting point. Germany's quest for nationhood dominated much of the nineteenth century, and is a central theme of this work. Conversely, what a nation is, and what it means, remains the subject of significant scholarly debate. In his review of Johannes Willms' Nationalismus obne Nation, the social historian Hans-Ulrich Wehler dismisses the central conceit of the book as self-explanatory: "naturally there was in the German states a [form of] nationalism since the eighteenth century", Wehler claims in somewhat poor temper. ${ }^{3}$ If this is a "natural" conclusion, however, it is one that eludes many scholars. Michael Hughes warns that "nationalism theory has become something of a quagmire, deep and muddy, frequently not worth the struggle." ${ }^{4}$ Wehler himself, in the same review of Willms' work, offered his own, somewhat confusing caveat. The nationalism of the eighteenth century, he writes, is obvious "if one understands the great emancipation and integration ideology of post-revolutionary modernity as such."5 Whether one should understand emancipation and integration to be a kind of nationalism, however, is not entirely clear, nor what Wehler means by these terms. Conversely, what is obvious is that there is little consensus as to the form that nationalism takes - its characteristics, its origins, its consequences. In no other country's history is the preoccupation with these

\footnotetext{
${ }^{2}$ Michael Hughes, Nationalism and Society: Germany 1800-1945 (London: Edward Arnold, 1991), 8.

${ }^{3}$ Hans-Ulrich Wehler, "Nationalismus ohne Nation? Ein anspruchsvoller, aber mißglückter Versuch", Die Zeit, 9 December 1983. All English translations of German passages in the present work are the author's own unless otherwise stated.

${ }^{4}$ Michael Hughes, Nationalism and Society, 8.

5 Hans-Ulrich Wehler, "Nationalismus ohne Nation?" Die Zeit, 9 December 1983.
} 
questions clearer than in Germany's. ${ }^{6}$ This work is not intended to be a forum within which to criticise theories of nationalism and nationhood, but rather the contemporaneous conception of the nation within the nineteenth century German and Württemberg context.

In part, the emphasis of German history on nationalism can be explained by the central role played by the German concept of nationhood in the twentieth century, and particularly during the years of the National Socialist Third Reich. Yet nationalism played a vital role in the very earliest of histories of unified Germany, before National Socialism (or, indeed, Hitler) had been conceived. The first efforts - those of the Prussian-born German historians Heinrich von Treitschke and Heinrich von Sybel - emphasised the romanticised liberal-nationalist origins of the German state.7 The Kingdom of Prussia was a guiding, protective power, which was able to focus the desire of the disparate Germans to become one. There was as much political impetus for this body of work as there was historical. Germany was young, its people for the first time united. It was therefore urgent that the recorded history of Germany should reflect the liberal-nationalism of the great

\footnotetext{
${ }^{6}$ Though nationalism theorists often disagree on the nature of the nation as an organic or an artificial construct - that is, a structure of authority and organisation that human social psychology tends towards, or one which is imposed by an authority to overcome individual identity and agency for the (presumed) benefit of a "greater good" - the characteristics listed here are (generally) agreed to be those by which a "nation" is defined. This will be explored in greater depth in Chapter 1. See also, for general discussions on nationalist theory (that do not necessarily refer specifically to Germany), Anthony D. Smith, The Ethnic Origins of Nations (Oxford: Basil Blackwell, 1988); Ethnicity, eds. John Hutchinson and Anthony D. Smith (Oxford: Oxford University Press, 1996); Benedict Anderson, Imagined Communities: Reflections on the Origin and Spread of Nationalism (London: Verso, 2006). For theoretical texts with specific reference to the German case, see also Nation-Building in Central Europe, ed. Hagen Schulze (Leamington Spa: Berg, 1987); John Breuilly, Nationalism and the State (Manchester: Manchester University Press, 1982), in particular pp.65-89; Hans Kohn, The Mind of Germany: The Education of a Nation (New York: Scribner, 1960); Louis L. Snyder, German Nationalism. The Tragedy of a People: Extremism contra Liberalism in Modern German History (Harrisburg: Stackpole, 1952); A.J. Hoover, The Gospel of Nationalism: German Patriotic Preaching from Napoleon to Versailles, 1806-1918 (Stuttgart: Franz Steiner, 1986); James J. Sheehan, German Liberalism in the Nineteenth Century (Chicago: University of Chicago Press, 1978). An excellent discussion of the origins and problems of German nationalism before the creation of Germany can be found in Joachim Whaley, Germany and the Holy Roman Empire, Vol.1: Maximilian I to the Peace of Westphalia 1493-1648 (Oxford: Oxford University Press, 2013).

${ }^{7}$ Of particular note here are Heinrich von Treitschke, Deutsche Geschichte im 19. Jabrhundert, 2 Vols. (Leipzig: A Kröner, 1934), and Heinrich von Sybel, The Founding of the German Empire by William I, Based Chiefly Upon Prussian State Documents, 5 Vols. (New York: Thomas Y. Crowell \& Co., 1890-1898). See also Heinrich von Treitschke, Historische und Politische Aufsätze, 3 Vols. (Leipzig: S. Hirzel, 1886-1897).
} 
early German nationalists, such as Ernst Moritz Arndt and Ludwig Jahn, and emphasise that the German people were united in culture, language, patrimony, blood and history.

Treitschke and Sybel, of course, are not the only historians who have focused on the popular and cultural will of the German Volk as the defining characteristic of the German unification, with Prussia as the standard-bearer. Certainly, this romanticised view did not go unchallenged. S.H. Steinberg's A Short History of Germany, appearing in Britain and the United States just as the Second World War drew towards its inexorable conclusion, dismissed Germany as being a popular expression of nationality. Germany, he claimed, "henceforth was [the term] used for the centralistic power-state of Greater Prussia padded out with those remainders of the old system which were allowed to vegetate on Prussian sufferance." Germany was emphatically not united, according to Steinberg, but subjugated under Prussian domination. Thus, the unification was not so much thirty-seven German states banding together, but thirty-six German states bowing to one — Prussia — as their overlord $9^{9}$

Steinberg, however, was overshadowed by his English contemporary, A.J.P. Taylor, whose Course of German History, first published in 1944, would become one of the most influential and one of the most controversial texts produced on German history. The truth, according to Taylor, is somewhere in the middle; yes, Prussia was the dominant German power, but the other German states acted essentially as "Little Prussias", and their unification under Prussian dominion was the uniting of a people similarly and peculiarly barbarous and militant as the Prussians themselves. ${ }^{10}$ That Taylor and, later, the similarly controversial Hamburg historian Fritz Fischer trace an unbroken line of German continuity

\footnotetext{
8 S.H. Steinberg, A Short History of Germany (Cambridge: Cambridge University Press, 1945), 220.

9 In fact, the German Confederation contained thirty-eight German states. The missing state in the national unification, of course, was Austria. Wolfgang Renzsch, "German Federalism in Historical Perspective: Federalism as a Substitute for a National State”, Publius 19, 4 (Autumn 1989), 18.

10 A.J.P. Taylor, The Course of German History: A Survey of the Development of German History since 1815 (London: Routledge, 2008).
} 
well into the past demonstrates their belief that the German tradition is uninterrupted and common. Germany is Prussia, so they say, as much as Hitler is a direct successor to Otto von Bismarck. ${ }^{11}$ Steinberg and Taylor did not write in a political vacuum, and the years of 1944 and 1945 were not conducive years for fair and balanced discussions of Germany, which had spent the last half-decade rampaging through Europe and doing its best to destroy the fabric of civilised European society.

Since Taylor, a wealth of work on the formation of Germany has appeared, and in the seventy years since its publication, The Course of German History has become woefully outdated, its conclusions a product of the time in which it was first written. For all this, it is eminently readable, and its polemic nature, while arousing suspicion amongst the pantheon of the German historians, makes it extremely accessible to the interested reading public and the student of history alike. Certainly, its near-constant reissuing (the latest edition having been published by no less distinguished publisher than Routledge, as recently as 2008) speaks volumes of the popularity and an influence in shaping popular understanding of German history that most other monographs on the subject can scarcely claim.

\section{The Small State in German Historiography.}

This is not to say that the other states of Germany have been entirely neglected, although the studies of these are not as numerous as those centring on Prussia, and they are mostly limited to academic monographs. As a result, they generally lack the ability to situate themselves in the public consciousness in a fashion similar to Taylor and his work.

One of the most important works to question the nature of the German unification is David Blackbourn's The Long Nineteenth Century. To Blackbourn, German unification as an idea was inevitable, but what was not clear was the model it would follow. The

\footnotetext{
11 Taylor attempts to draw the line of German continuity back as far as Charlemagne. This is an especially long bow to draw, given that the French claim Charlemagne as their precursor as much as the Germans do.
} 
centralised, Berlin-based bureaucracy was merely one outcome, albeit the most likely. ${ }^{12}$ Where Blackbourn has been cautious, others have tried to plunge headfirst into the murky waters of pre-unification Germany, with varying degrees of success. James J. Sheehan's seminal German History 1770-1866 remains arguably the gold standard for Englishlanguage studies of pre-unification Germany, and its focus sits very firmly on the German region as a whole, not simply one or two more important countries. More recently, Oxford University's Abigail Green has fought to bring the "lesser" German states to our attention. Green's Fatherlands: State-Building and Nationhood in Nineteenth Century Germany focuses on the institutions and traditions of the kingdoms of Saxony, Hanover and Württemberg. ${ }^{13}$ Green's work has been complemented by those of other scholars, emphasising the particularist roots of many of the Kleinstaaten (small states) or Mittelstaaten. In particular, and perhaps unsurprisingly, these works have tended to focus on the larger, more 'important' Mittelstaaten, such as Bavaria or Saxony. ${ }^{14}$ As a result, they tend to fall into the trap of removing Prussia from the German Question, but finding a proxy replacement. This, of course, is hardly something that Bavaria or Saxony can fulfil.

Of more general works, the late Thomas Nipperdey's expansive Deutsche Geschichte series is a masterful achievement of quantitative and qualitative analysis of German society as a whole throughout the nineteenth century, and as such it does not fall within the norms

\footnotetext{
12 David Blackbourn, The Long Nineteenth Century: A History of Germany, 1780-1918 (New York: Oxford University Press, 1998), passim.

13 James J. Sheehan, German History 1770-1866 (Oxford: Clarendon Press, 1989); Abigail Green, Fatherlands: State-building and Nationhood in Nineteenth-Century Germany (Cambridge: Cambridge University Press, 2001).

14 Such works are far too numerous to list with any degree of comprehensiveness. However, special note must be made of Lothar Gall's Der Liberalismus als regierende Partei (Wiesbaden: F. Steiner, 1968), which comprehensively details the internal liberal political development of the Grand Duchy of Baden; Nicholas Martin Hope's contentious but ambitious The Alternative to German Unification: The Anti-Prussian Party: Frankfurt, Nassau, and the Two Hessen, 1859-1867 (Wiesbaden: F. Steiner, 1973), which (unconvincingly) paints the aforementioned states as bastions of particularist, as well as German, "freedom" from Prussia through Greater German sentiments; and Theodore S. Hamerow, though focusing on social class structure, rather than state apparatus, as the medium of unification, admirably approaches the issue in The Social Foundations of German Unification, 1858-1871, Vol.I: Ideas and Institutions, and Vol.II: Struggles and Accomplishments (Princeton: Princeton University Press, 1969-1972).
} 
of the old "Borussian school" of German history, which focuses largely on Prussia. ${ }^{15}$ Dieter Langewiesche, meanwhile, has investigated the democratic traditions of Württemberg. ${ }^{16}$ In reference to specific events, the smaller states are also well-represented; Hans-Werner Hahn's work on the formation of the German Customs Union, or Zollverein, bases its argument on the experiences of the states of Hesse-Kassel and Hesse-Darmstadt, for example, and Manfred Hanisch's Für Fürst und Vaterland, dealing with Bavaria, is a particularly impressive academic work on that state's political development during the formative years that led to unification. ${ }^{17}$ Most recently, Brendan Simms' ambitious survey of German history, Europe: The Struggle for Supremacy, contains a masterful overview of the role of the smaller states as a whole throughout a period of five centuries. The expansive nature of the book, however, precludes a more in-depth analysis of the role of each of these states in the context of specific examples and events. ${ }^{18}$

These works are important, not just because they investigate states and parties that are otherwise drowned out of the German historical discourse, but because they implicitly acknowledge that there is far more to German history than the meek cowing of the smaller states, or the (perhaps) forced conformity to Prussia, would convey. At the same time, however, they perpetuate their own problems. Historians, by and large, are diplomatic, and with some exceptions are no longer prone to the same bombastic judgements as evidenced in the works of bygone historians like A.J.P. Taylor. These nuanced and conscientious

\footnotetext{
15 Thomas Nipperdey, Deutsche Geschichte 1800-1866, 1.Bd.: Bürgerwelt und starker Staat (Munich: C.H. Beck, 1998); Thomas Nipperdey, Deutsche Geschichte 1866-1918, 1.Bd.: Arbeitswelt und Bürgergeist, and 2.Bd.: Machtstaat vor der Demokratie (Munich: C.H. Beck, 1998).

16 Dieter Langewiesche, Liberalismus und Demokratie in Württemberg zwischen Revolution und Reichsgründung (Düsseldorf: Droste-Verlag, 1974).

17 Hans-Werner Hahn, Wirtschaftliche Integration im 19. Jabrhundert: Die hessischen Staaten und der Deutsche Zollverein (Göttingen: Vandenhoeck \& Ruprecht, 1982); Manfred Hanisch, Für Fürst und Vaterland. Legitimätsstiftung in Bayern zwischen Revolution 1848 und deutscher Einheit (Munich: Oldenbourg, 1991).

18 Brendan Simms, Europe: The Struggle for Supremacy 1453 to the Present (London: Allen Lane, 2013). Similar themes were explored in the same author's earlier work, The Struggle for Mastery in Germany, 1779-1850 (London: Palgrave Macmillan, 1998).
} 
works, regardless of their exceptional scholarship or discursive elegance, may achieve academic acclaim but do not fire the passions of the interested reading public in the same way that Taylor's oversimplified fire-and-brimstone approach continues to do. While the Taylorite Borussian model is nowadays in decline, derided by historians of Germany Abigail Green having recently remarked that the time of the Borussian school is long passed $^{19}$ - it is telling that most of these works somewhat self-consciously place themselves in direct opposition to Taylor and his Prussocentric views. Perhaps the Borussian school is dead and buried, but its spectre haunts academic studies of Germany like a malevolent Poltergeist, and the best efforts of the new acolytes of German history have yet to exorcise it.

\section{Württemberg and the Methodology of Unification Studies.}

Why, then, when the historiographical body continues to struggle against Prussia’s ghost, should we focus on Württemberg? After all, Württemberg may have been larger than Baden, but it was neither geographically bigger nor politically, economically, or militarily on a par with other Mittelstaaten such as Bavaria and Saxony (of which there are already several studies), let alone Austria or Prussia (of which there are more.) Arguably, though, it is this which makes Württemberg a logical case study for the German experience during the unification process. The state's role as a Mittelstaat makes it more representative of the 'typical' German state experience, inasmuch as there can be a typical experience of so many disparate states. Austria and Prussia, with their enormous populations and expansive territories, wielded far greater economic and political power than their counterparts.

\footnotetext{
${ }^{19}$ Abigail Green, “The Federal Alternative? A New View of Modern German History”, The Historical Journal, 46, 1 (March 2003), 187.
} 
On the other hand, Württemberg's size made it similar to Hanover, Saxony, the two Hessian states, ${ }^{20}$ Baden, and numerous other middle-states. Its economy, not superior by any means, worked in close conjunction with those around it. In times of war, Württemberg could wield military power that was comparable to that of the other Mittelstaaten. Like Baden, it had a strong tradition of liberal political engagement in civil society; like Bavaria, it tempered this liberalism with occasional forays into monarchical absolutism. Like all of the Mittelstaaten, Württemberg's economy was driven by agriculture and, though it was slower than some other states to adopt a statewide economic policy that favoured industry, it began to industrialise with modern machinery supplanting traditional manufacturing methods in a similar timeframe as its counterparts. Moreover, while some of the Mittelstaaten were exclusively aligned with Austria or Prussia during this period, Württemberg's geographical position, not to mention its dynastic ties, meant that it would, at various points, foster favourable relations with both of the German great powers, as well as foreign powers, such as France and Russia. In a sense, then, while the experience of Württemberg and Württembergers during this period cannot be a comprehensively accurate representation of the experience of all Germans (or even, all non-Austrian, nonPrussian Germans) between 1815 and 1871, it can be considered similar to a line of best fit. Thus, a study of Württemberg's role during these years of change, and what effect those years had on the state itself, approximate the role of other comparable Mittelstaaten during the same era.

Finally, Württemberg is an important subject for a case study for the simple reason that it is so fascinating. While historians writing many years later have dismissed the importance of the Mittelstaaten in German politics, Württemberg's political masters and

20 These two provinces, the Grand Duchy of Hesse (Großherzogtum Hessen) and the Electorate of Hesse (Kurfürstentum Hessen, often shortened to Kurhessen), follow the curve of the Rhine to the north of Baden. In order to avoid confusion, they are most commonly referred to in this text by their colloquial names: HesseDarmstadt for the grand duchy, and Hesse-Kassel for the electorate. Darmstadt and Kassel were the capitals of their respective states. 
press men certainly did not feel likewise at the time. On more than one occasion, the kingdom attempted to take control of regional national efforts. In other cases, Stuttgart took part in elaborate plans of subversion and deceit. In yet more cases, the state cooperated with the great powers. In each instance, however, Stuttgart and the powers-that-be in the Neues $S c h l o \beta$ worked in accordance with their own conception of Württemberg's greater good. The state's development may have been roughly representative of that of the Mittelstaaten, but it was also unique. Regardless of the hue and cry of German nationalists, the various German states were not homogenous, and Württemberg demonstrated, time and again, curious divergences from what we may have considered the 'norm.' Therefore, in its own right, Württemberg deserves reappraisal.

Württemberg has a long history. Though its status as a kingdom was only conferred in 1806 , it had already existed for centuries as a reasonably self-sufficient duchy. Politically and economically, it had been largely stable, if unspectacular. Accounts from the period paint a picture of a pleasant, placid, rural province, untroubled and untouched by modern politics and society. In 1854, the French author Jacques Boucher de Perthes, touring the southern German states, remarked of Württemberg that the picturesque towns and villages dotting lush dales and hillsides seemed to engender a oneness with the natural beauty of the land. The only impact of man upon this scenery, according to the Frenchman, were scattered plantations. ${ }^{21}$

The rolling countryside, spotted here and there with crops, livestock, and small villages, would eventually give way to the cities and towns of the kingdom, none of which would really change Boucher de Perthes' mind about the quaint and idyllic countryside charm of Württemberg. The prolific English travel novelist, Frances Trollope (better known by the diminutive nickname "Fanny"), saw even the largest of Württemberg's towns,

\footnotetext{
${ }^{21}$ Jacques Boucher de Perthes, Voyage en Danemarck, en Suede, en Norvege, par la Belgique et la Hollande, retour par les villes anséatiques, le Mecklembourg, la Saxe, la Bavière, le Wurtemberg et le Grand-Duché de Bade, séjour à Bade en 1854 (Paris: 1858), 431.
} 
including the capital of Stuttgart, as "any other [...] ordinary village." Certainly, compared to what Trollope was familiar with in England, Württemberg's towns were little more than sleepy hamlets. When the Imperial City of Reutlingen was absorbed into the kingdom in 1806, its population scarcely numbered 10,000, yet it became Württemberg's fifth-largest town. ${ }^{22}$ Nor did the duchy overly impress the infamous Lothario, Giacomo Casanova, whose most complimentary observation was that he enjoyed a "capital supper" in Ludwigsburg. Stuttgart, on the other hand, was a "wretched" place, although this is unsurprising, given the characteristically fantastic misadventures Casanova apparently suffered in the city. ${ }^{23}$ Casanova and his contemporaries seem to have viewed Stuttgart as the aberration of the duchy, however; the journalist Wilhelm Ludwig Wekherlin felt that Stuttgart was "populated by a mass of ugly buildings" and inhabitants whose "manners and way of life are uncivilised", but he, like Boucher de Perthes, found much to praise in the idyllic countryside. $^{24}$

However, physical beauty does not govern a state, and Württemberg could not exist as an autonomous country based solely on its lovely landscape. Politically, the state was remarkably progressive for its time. Charles James Fox's famous suggestion that Württemberg was only one of two constitutional states in all of Europe was correct insofar that Württemberg did indeed have a constitution, and a relatively liberal one at that. The Treaty of Tübingen, enacted in 1514 , had guaranteed a unique power-sharing agreement between the hereditary ruler and the estates, or Stände. The treaty guaranteed personal

\footnotetext{
22 Frances Trollope, Vienna and the Austrians; with Some Account of a Journey through Swabia, Bavaria, the Tyrol and Salzbourg (London: R. Bentley, 1838), 42; Dieter Langewiesche, Liberalismus und Demokratie in Württemberg zwischen Revolution und Reichsgründung (Düsseldorf: Droste-Verlag, 1974), 45; Abigail Green, Fatherlands: State-building and Nationhood in Nineteenth-Century Germany (Cambridge: Cambridge University Press, 2001), 29.

23 Indeed, according to Casanova, he was drugged by three officers, and lost his fortune while gambling. Regardless, before he had arrived in the Württemberg capital, he expected he would enjoy a "pleasant stay", indicating that, at this time, Stuttgart was at least reasonably well thought of - not to mention, important enough for Casanova's short tour of Germany. Giacomo Casanova, The Memoirs of Jacques Casanova de Seingalt, Vol.III: The Eternal Quest (New York: G.P. Putnam's Sons, 1961), 369-384.
}

${ }^{24}$ Wilhelm Ludwig Wekherlin, Anselmus Rabiosus Reise durch Oberdeutschland (Salzburg: 1778), 56. 
liberties, a recourse to a centralised legal authority, and, most crucially, legislated that the Württemberg crown could not unilaterally determine domestic or foreign policy objectives. Instead, it required the approval of a collection of representatives of the Stände, in a parliament known as the Landtag. ${ }^{25}$ In this way, the duke (or, later, the king) of Württemberg did not rule as an absolutist. His power was checked by the balance of the Landtag, which acted as a representative assembly for a limited, masculine suffrage.

This arrangement was peculiar enough — indeed, as Fox noted, the only other state with something similar was Great Britain — but the Stände of Württemberg were also unique. Unlike the Prussian Junkers or similar classes in the rest of Germany, the Stände were by and large not composed of or dominated by the nobility, but rather by the "Geistlichkeit und die Bürgerschaft", or clergy and leading civil figures. More often than not, these representatives of the citizenry were those who owned arable lands and, though this was not always the case, this meant that the Stände often had vested interests in matters of agricultural policy. ${ }^{26}$ The Württemberg estates, therefore, had been granted far more power over the politics of the country than in neighbouring states, and while this garnered high praise among many liberal personalities, the meddling of the Landtag did not necessarily lend itself to efficient policy-making. ${ }^{27}$

Württemberg's institutions were, therefore, quite unique. It is thus surprising, especially given the importance and centrality of Württemberg (and its successor in the Federal Republic of Germany, the state of Baden-Württemberg) to Germany's academic

\footnotetext{
25 Duke Ulrich von Württemberg, "Tübinger Vertrag zwischen dem Herzog Ulrich von Württemberg als Landesherrn und den Prälaten und der Landschaft von Württemberg als Vetreter der Landstände”, Tübingen, 8 July 1514 .

${ }^{26}$ Karl Weidner, Die Anfänge einer staatlichen Wirtschaftspolitik in Württemberg (Stuttgart: Kohlhammer, 1931), 112.

27 Even the harsher critics of Württemberg conceded that the theory of its dualist rule was remarkably fair. Casanova, though no fan of the duke of Württemberg, admitted that the court of Stuttgart was "the most brilliant in Europe"; Wekherlin, on the other hand, claimed that the crown was "the most philosophical" of all the German courts. Giacomo Casanova, The Memoirs of Jacques Casanova, Vol.III, 369; Wilhelm Ludwig Wekherlin, Anselmus Rabiosus Reise durch Oberdeutschland, 54.
} 
heritage, that the role of the state in the unification of Germany is all but neglected in historical studies. ${ }^{28}$ Indeed, Württemberg has distinguished itself scholastically over the decades and centuries. The capital city, Stuttgart, hosts no fewer than three academic publishing houses of some repute. ${ }^{29}$ The city of Tübingen, roughly thirty kilometres south of Stuttgart, is home to the famous Eberhard Karls Universität, a distinguished university that is one of the oldest and most celebrated in Europe..$^{30}$ The same institution has also produced, either as alumni or as academic staff, a plethora of excellent historians, including the Nazi Germany specialist, Hans Mommsen, and the former federal German chancellor, Kurt Georg Kiesinger. Tübingen has not neglected state history, however, and to that end has fostered the careers of, in particular, Dieter Langewiesche, whose 1974 work Liberalismus und Demokratie in Württemberg zwischen Revolution und Reichsgründung constitutes an impressive and formidable analysis of the origins of Württemberg liberalism before 1871, and Paul Sauer, whose three-volume set of Württemberg monarchical biographies is an important contribution to the field. ${ }^{31}$ Moreover, the homegrown Commission for Historical Regional Studies in Baden-Württemberg and the Württemberg Historical and Antiquities Association (Kommission für geschichtliche Landeskunde in Baden-Württemberg und Württembergischer Geschichts- und Altertumsverein) publishes a

\footnotetext{
28 While there have certainly been relevant studies, none uses the nineteenth century as a whole as the context of unification. As a result, while they are useful, these works all too often ignore vital contextualisation. See, for instance, Adolf Rapp, Die Württemberger und die nationale Frage 1863-1871 (Stuttgart: W. Kohlhammer, 1910); Gerlinde Runge, Die Volkspartei in Württemberg von 1864 bis 1871. Die Erben der 48er Revolution im Kampf gegen die preussischkleindeutsche Lösung der nationalen Frage (Stuttgart: W. Kohlhammer, 1970); Peter Hoffmann, Die diplomatische Beziehungen zwischen Württemberg und Bayern im Krimkrieg und bis zum Beginn der italienischen Krise 1853-1858 (Stuttgart: W. Kohlhammer, 1963).

29 These are, in turn, the great publishing houses of Wilhelm Kohlhammer (1866), Ernst Klett (1897) and, more recently, Konrad Theiss (1956).

30 Unsurprisingly, the university city is also home of one of the oldest bookstores in Europe (Osiander'sche Buchhandlung, first opened in 1596.) Walter Jens, Eine deutsche Universität. 500 Jahre Tübinger Gelehrtenrepublik (Munich: Kindler, 1993), passim.

31 Paul Sauer, Der schwäbische Zar: Friedrich, Württembergs erster König (Stuttgart: Deutsche Verlags-Anstalt, 1984); Paul Sauer, Reformer auf dem Königsthron: Wilhelm I. von Württemberg (Stuttgart: Deutsche VerlagsAnstalt, 1997); Paul Sauer, Regent mit mildem Zepter: König Karl von Württemberg (Stuttgart: Deutsche VerlagsAnstalt, 1999).
} 
well-respected yearly journal devoted solely to Württemberg history (Zeitschrift für Württembergische Landesgeschichte.) However, while the Reichsgründung may be mentioned in passing in many of these works, little effort has been devoted to the German Question's role in Württemberg public affairs, be they political or social. It would seem that the unification is still regarded as a Prussian-driven affair of either aggression or romanticism. To suggest this, however, is to suggest that thirty-five German states, including Württemberg, had no agency whatsoever in their own futures and fates. These are questions, apparently, to be left to the purview of great Prussian iconoclasts, such as King Wilhelm I and and Otto von Bismarck, but not to King Ludwig or Grand Duke Wilhelm or Count Ferdinand von Beust or the rest of Germany. This denies precisely what Sheehan, Langewiesche, Green, Nipperdey and others have been at such great pains to demonstrate.

If this is the case, then, Württemberg is a natural choice as a case study of the centrality of the Mittelstaaten. This is true for a number of reasons. Firstly, Württemberg is practically convenient. The aforementioned academic traditions of the state have allowed a large number of regional studies to be published which, while not expressly addressing the Reichsgründung, provide important context. In no small part, this is supported by the excellent collection of primary source documents held at the Hauptstaatsarchiv in Stuttgart. In spite of the devastation suffered by Stuttgart through extensive area bombing during the Second World War, nineteenth-century state, diplomatic, and press records have survived largely intact; this is not the case in many other states and cities, such as Bavaria or Frankfurt am Main, where the bulk of archival material was incinerated by incendiaries and high explosives. The Hauptstaatsarchiv also houses many collections of personal papers of leading social and political figures of the eighteenth and nineteenth centuries. This work makes use of these archival holdings, in particular the variety of diplomatic dispatches to and from Württemberg consulates, embassies, and missions in the other German states, as 
well as France, Russia, and Britain. Policy documents, memoranda, and journals of leading political figures are also to be found at this archive, and are used extensively.

Württemberg's heritage of political awareness also inspired a dynamic popular press. In particular, the Württemberg population had access to three extremely important newspapers: the official Staatsanzeiger für Württemberg (State Gazette for Württemberg), the vehemently particularist and anti-Prussian newspaper Der Beobachter (The Observer), and the populist and mildly left-leaning Schwäbischer Merkur (Swabian Mercury) and its weekend edition, the Schwäbische Kronik (Swabian Chronicle.) The print runs of these press organs have remained largely intact and accessible through the Hauptstaatsarchiv, allowing an insight into the news services that shaped and, in turn, were shaped by public opinion.

In addition, a number of smaller town archives survived the Second World War unscathed. Esslingen, for instance, was far enough away from the capital (and from the industrial works along the Neckar) that it was never subjected to Allied bombardment; its Stadtarchiv holds a large collection of, among other things, regional electoral records dating back at least as far as the first elections after the Napoleonic Wars. Furthermore, though Württemberg may have been been a smaller state compared to Prussia or Austria, it was large enough to have a diplomatic presence within its neighbours. As a result, records relating to Württemberg exist in a number of archives throughout Germany; in the case where sources have been lost in Stuttgart or elsewhere in Württemberg, for the most part they can be reproduced through complementary research in Berlin, Darmstadt, or other cities. Of special note are the three main archives in Berlin — the Geheimes Staatsarchiv Preußischer Kulturbesitz (Confidential State Archive of the Prussian Cultural Heritage Foundation), the Bundesarchiv (Federal Archive), and the Politisches Archiv des Auswärtigen Amts (Political Archive of the Foreign Ministry); each of these archives houses an impressive array of diplomatic documents from Prussian functionaries, as well as a variety of proceedings from the Assembly of the German Confederation. 
Finally, the German Question was not only of interest to those states that would potentially become part of a united Germany. Indeed, neighbouring powers observed, and in some cases were preoccupied by, the development of the German national consciousness. In particular, British observers were particularly interested, as a a shift in the German power structure would likely shift the balance of power in continental Europe, which British foreign policy was, as a rule, at great pains to preserve. A succession of British envoys to Stuttgart enjoyed close relations with the Württemberg king throughout most of this period, Wilhelm (1817-1863), and these envoys often provided extensive and detailed reports on the political, diplomatic, and social conditions within Württemberg. These reports are held at the National Archives in Kew, but a selection is also available in published form thanks to the excellent Camden Series of envoy reports. ${ }^{32}$ These edited collections are not only instructive in their own right, but they also provide extensive biographical notes on the dramatis personae - an addition that is absolutely vital in order to keep track of the revolving roster of British emissaries and other key diplomats during the era.

\section{Intentions.}

The end result of the use of these sources, as well as a large amount of secondary literature, is to present a comprehensive picture of Württemberg during its most tumultuous period of existence. By using internal memoranda, telegrams between consular offices, the observations of foreign diplomats, and the reportage of the three most important Württemberg newspapers (as well as others from foreign states), this work will show Württemberg's official, semi-official, and public attitudes and responses to the question of

\footnotetext{
32 British Envoys to Germany, 1816-1866, Vol.1: 1816-1829, eds. Sabine Freitag and Peter Wende (Cambridge: Cambridge University Press, 2000); British Envoys to Germany, 1816-1866, Vol.2: 1830-1847, eds. Markus Mösslang, Sabine Freitag and Peter Wende (Cambridge: Cambridge University Press, 2002); British Envoys to Germany, 1816-1866, Vol.3: 1848-1850, eds. Markus Mösslang, Torsten Riotte and Hagen Schulze (Cambridge: Cambridge University Press, 2006); British Envoys to Germany, 1816-1866, Vol.4: 1851-1866, eds. Markus Mösslang, Chris Manias and Torsten Riotte (Cambridge: Cambridge University Press, 2010).
} 
unification, and the role that this debate played within the Württemberg bodies politic, social, and economic.

In Chapter 1, the reader will be presented with a "prehistory" of Württemberg in the mirror of German nationalism. In particular, this will focus on the era of the Napoleonic Wars, in which German nationalism, which had previously been only of minor significance, blossomed under the pressure of foreign aggression. During this time, Württemberg and many of its neighbouring states grew in influence and power, and this engendered in the political class a particularism that often clashed with the pan-German identity beginning to develop elsewhere. Moreover, the influence of Napoleon on Germany, not to mention the privations inflicted upon the people of the German states, would shape much of Germany's development in subsequent years. In particular, the German sphere was left with two major powers - Austria and Prussia - and it was largely expected that, if the German states were to unify, the impetus and leadership for this unification would come from either of these two countries.

The relationship of Württemberg to the possibility of an Austrian-led Germany (and vice-versa) is the subject of Chapter 2, while Chapter 3 focuses on a similar possible development, but through the aegis of the Hohenzollern Kingdom of Prussia instead of the Habsburg Austrian Empire. Chapter 4 traces Stuttgart's attempts to remain independent, and asks whether this was actually a realistic goal in post-Napoleonic Germany. Another model of German unification - the often-overlooked but paradoxically influential 'Third Germany', being a conglomeration of smaller, usually southern, German states - is also examined in this chapter. These early unification efforts, in the first half of the nineteenth century, were interrupted by the outbreak of liberal and nationalist revolutions throughout all of Europe and Germany, including Württemberg, in 1848. In Chapter 5 and 6, it is contended that 1848 is actually the starting point in eleven years of development of a nationalist consciousness in Württemberg, in which the Third German concept became the 
most popular and, apparently, most likely model of national unification, both among the press and public as well as within the halls of power themselves. These efforts were defeated by a concentration of hostile circumstances at the end of the 1850 s, although the Third German concept did not, by any means, die. In fact, as Chapter 7 shows, between the years of 1860 and 1866, as diplomatic relations between Austria and Prussia deteriorated, the southern Mittelstaaten continued to influence the situation in an attempt to forge their own destiny in a German unification whose existence now appeared all but inevitable. Finally, as war broke out between Austria and Prussia in 1866, the Mittelstaaten found themselves caught in the middle of an impossible scenario. The resultant post-war German developments gradually swung circumstances in favour of Prussian-led German unification but, as Chapter 8 demonstrates, at no point was this road to the ultimate 1871 founding of the German Empire an unreasonable or irresistible path. On the contrary, when the decision was finally made to follow Prussia's lead, it was done so willingly and consciously by states who were not coerced into subjugation, but who recognised the overwhelming logical benefits of this initiative. In short, there was nothing about this unification that could be characterised as being the product of overwhelming force, nor of fanciful concepts of nationality. This was, in fact, a development that was actively initiated by rational states, who until the very last had control and agency over their own affairs. This was indeed a truly popular unification, not a conquest of arms or ideas.

The history of Germany and its gradual march towards unity is one that requires revision. As this work will demonstrate, destiny was certainly influenced to a great extent by the larger powers, but the smaller states also had important roles to play. None of the motives for doing so are inscrutable, and the behaviours that determined the manner in which these roles were performed were neither common nor predetermined. Ralf Dahrendorf, in his influential 1968 work Society and Democracy in Germany, noted that the historical discourse is permeated with the idea that the German experience was a common 
one, and that any German should think and behave like any other German, "much as 'the man', 'the secondary school teacher', 'the fellow clubman' [should]."33 Much as Dahrendorf did, the following pages will demonstrate that this common experience is a myth. Unlike Dahrendorf's work, they will also prove that, somewhat paradoxically, these unique political, economic, social and cultural experiences contributed to the foundation of the unified German nation. Our exemplar for this is the Kingdom of Württemberg.

${ }^{33}$ Ralf Dahrendorf, Society and Democracy in Germany (London: Weidenfeld \& Nicolson, 1968), 26. 


\section{CHAPTER 1 \\ STATES AND NATION IN THE LATE EIGHTEENTH AND EARLY NiNETEENTH CENTURY}

BEFORE DISCUSSING THE agency, role, and influence of the Kingdom of Württemberg in the nineteenth century, it is useful to examine and account for the state of the German region as a whole at the end of the eighteenth century. By 1789 , some 360 states, many of their territories making up the modern nation-state of Germany, were part of the Holy Roman Empire. This was a loose collection of principalities, each of which enjoyed a significant degree of autonomy. Indeed, even to define what the Holy Roman Empire was is a difficult undertaking. There was no capital, no united imperial army, no consolidated foreign or domestic policy, and its members were free to forge their own alliances, treaties and agreements with other states.

Nevertheless, despite the autonomy which the Holy Roman Empire offered, it was much derided, due to its institutional weaknesses. This weakness influenced, and in turn was influenced by, a rising sense of nationalism and German regional particularism, though this nationalism was embryonic, the purview of ambitious princes and the fertile imaginations of philosophical literarians. These expressions of nationalism — such as it may be called - nonetheless tapped into a nascent regional German concept of self, which was to begin a rapid crash course of troubled and convoluted development only after the Empire had fallen.

It is no coincidence that many of the most popular theatrical presentations of the era contain open criticism of the Holy Roman Empire. In Faust, Goethe's Auerbach Tavern rings with the cries of the student revellers lamenting: "The Holy Roman Empire. Oh, poor thing! How does it hold together?" Later, when Napoleon's victories wreaked havoc throughout central Europe in 1806, Goethe remarked that the ordinary squabbles of coachmen was more interesting than the end of the Empire. Karl von Moor, Schiller's protagonist in Die Räuber, similarly despaired of the Empire's irrelevance. Reflecting many 
of the views of his literary creator, Moor preferred to see Germany united as a republic, than under the ineffectual imperial diet. "Set me at the head of an army of fellows like myself", he declares as he sits in a tavern in Saxony, "and we will make Germany a republic compared to which Rome and Sparta will be but nunneries!"' Both Goethe and Schiller were early examples of German nationalists. They desired the creation of a united German nation-state, and their criticism of the Empire was not so much that it existed, but that it did not seem to signify anything.

\section{The Intricacies of the Holy Roman Empire.}

The Holy Roman Empire exists as one of the greatest enigmas of the early modern and modern periods of European history. That it existed is unquestionable, and that it was important, equally so. But what it actually was is difficult to define, and its lasting significance is obscured by the disdain heaped upon it and the events that overtook it. It was, as Voltaire once famously quipped, neither holy, nor Roman, nor much of an empire; centred largely on the states of central Europe rather than the domain of the Roman Empire of antiquity, it offered a loose, overarching political framework, some form of directed foreign policy, variable forms of taxation, and a centrally-mandated federal legal system that was (sometimes) adhered to by the constituent states. It did not operate as a nation-state in its own right, in spite of its appellation as an empire "of the German Nation.” Instead, the Empire was divided into 'districts' (Kreise), a ponderous regional system in which various neighbouring autonomous provinces were banded under a local administration, which was then answerable to the Empire as a whole. In its form, it was instead an early modern analogue of the European Union, holding much theoretical oversight over its member nations, while in a practical sense having little direct power of

\footnotetext{
${ }^{1}$ Johann Wolfgang von Goethe, Faust: A Tragedy, Part I, in Johann Wolfgang von Goethe, Selected Works (New York: Alfred A. Knopf, 2000), 797; Hagen Schulze, "The Revolution of the European Order and the Rise of German Nationalism", in Nation-Building in Central Europe, 5; Friedrich Schiller, Die Räuber. Ein Schauspiel von fünf Akten, Act I Scene II (Frankfurt am Main: 1787), 32.
} 
influence over the individual governments; indeed, inclusion in the Empire did not preclude member states from diplomatic or even military conflict amongst themselves.

Even in times of peace, the Empire offered few benefits. Taxation within the imperial borders was defined at a local level, as were matters of law. The German region was divided into over 1,800 tariff zones, each with its own regulations and tolls. On the relatively short 600 kilometre stretch of the Rhine between the city of Strasbourg and the Dutch frontier town of Nijmegen, for example, a trader might pass through over thirty distinct German customs zones, and each time he would be required to pay a locally-determined number of tariffs at a locally-determined rate. ${ }^{2}$ The existence of independent, imperially-mandated enclaves within sovereign states also complicated matters. In the case of Württemberg, the thirty kilometre journey between the state capital, Stuttgart, and the nearby town of Vaihingen an der Enz was subject to taxation of goods, because Vaihingen, which is today close enough to the centre of Stuttgart to be a suburb of the city, was an imperial city, and travellers between the two towns were therefore seen to be traveling between separate countries. Similar customs duties were introduced for travel to the imperial enclaves of Brackenheim, Göppingen, and Ulm. The exception was the imperial city of Heilbronn, some fifty kilometres north of Stuttgart. The Württemberg treasury had decided in 1342 that commercial traffic along the Neckar River between Württemberg towns and Heilbronn would not be taxed - a curious deviation from an already overly convoluted revenue system. ${ }^{3}$

The fact that the Holy Roman Empire was politically decentralised led to an era of dualism inside the German region. In the south, Austria - the seat of the Habsburg monarchy that presided over the Empire - was the most powerful geopolitical entity. Increasingly, a succession of Habsburg rulers had turned their attentions away from their

\footnotetext{
2 W.O. Henderson, The Zollverein (London: Frank Cass, 1984), 21-22.

${ }^{3}$ Karl Weidner, Die Anfänge einer staatlichen Wirtschaftspolitik in Württemberg (Stuttgart: Kohlhammer, 1931), 16.
} 
position at the head of the Empire, and more as the presider over their hereditary Austrian holdings. ${ }^{4}$ As early as 1684 , the Austrian civil servant Philip Wilhelm von Hörnigk had suggested that if the Habsburgs constrained themselves to Austria, then Austria would become the preeminent European great power, "if she only wills it." 5 By the 1740s, the dynasty itself had begun to mirror Hörnigk's earlier ideas. In direct contrast to the Holy Roman Empire's distinct lack of centralised bureaucracy, Austria had begun to develop a strong and dynamic state apparatus that stood independent from the Holy Roman throne. This was largely the result of the rule of Archduchess Maria Theresa (1740-1780), who, unable by virtue of her sex to preside over the Empire, nonetheless built up a strong political power base. Theoretically expected to hand control of Bohemia to her husband Franz, and later to her son Joseph II, both Holy Roman Emperors, Maria Theresa was able to resist doing so through both the tacit approval of her spouse and progeny, and also her extraordinary capacity for organisation and administration. Joseph was crowned Holy Roman Emperor in 1765, and endured the unique and presumably uncomfortable position of holding sway over the Empire with little direct power concentrated in his hands, while having little or no influence over his own ancestral lands, which remained true to the leadership of his mother. The lesson of these years was stark: the power behind the Holy Roman Empire was Austria, and while Austria could exist without the Empire the Empire could not exist without Austria. Joseph seems to have taken this to heart; in 1784, four years after Maria Theresa's death, he even considered abdicating the Holy Roman throne, so as to bolster his more concrete political and dynastic aspirations at home. ${ }^{6}$

\footnotetext{
${ }^{4}$ Robert A. Kann, A History of the Habsburg Empire 1526-1918 (Berkeley: University of California Press, 1974), 54.

5 Philip Wilhelm von Hörnigk, Oesterreich über Alles, wenn es nur will (Nürnberg: 1684), passim.

6 James J. Sheehan, German History 1770-1866, 16; Joachim Whaley, Germany and the Holy Roman Empire, Vol.II: The Peace of Westphalia to the Dissolution of the Reich 1648-1806 (Oxford: Oxford University Press, 2013), 417.
} 
This was not simply a question of dynastic politics. Increasingly, the Austrian Habsburgs were alarmed by the shortcomings of the Holy Roman Empire as a military union. Prussia's invasion of Silesia in 1740 stripped Austria of a prosperous region and, try as she might to reclaim it, Maria Theresa simply could not bring enough force to bear against the Prussians. In times of war, therefore, the Austrians could not rely on the Empire to furnish them with an adequate military force. ${ }^{7}$ Worse, Austria's own reserves were often bled dry in efforts to maintain imperial security on the fringes of the Empire, and even if the Empire chose to stand for Austrian interests, the fact that an Austrian stood at the head of the Empire by no means guaranteed the absolute and unconditional support of the member states. When Prussia invaded and occupied Saxony in 1756, for example, Maria Theresa saw this as a casus bellum to justify a war that could reclaim Silesia for Austria, and reduce or destroy Prussia's power in the north. This war, the Seven Years' War, did break out, but its results were not as Maria Theresa intended. While she had the support of Austria's partner states in the Empire, this support was conditional; the Empire's representative political body, the Reichstag, had only agreed to prosecute war against the Prussians so as to liberate Saxony, which had been invaded and occupied by Prussian troops at the beginning of hostilities. Once this was achieved, the Reichstag would be pleased to declare the Empire neutral, and so maintain a policy of coexistence. In the face of this imperial malaise, and the paltry number of troops supplied for the purpose by the other imperial states - the imperial army never numbered greater than 32,000 men - Austria could not hope to succeed in the manner its archduchess expected. ${ }^{8}$ After all, how could Austria continue a war, and wield overwhelming force, when the empire to which it

\footnotetext{
7 Karl Otmar von Aretin, Das alte Reich, 3.Bd.: Das Reich und der österreichisch-preussische Dualismus (1745-1806) (Stuttgart: Klett Cotta, 1997), 539. Aretin argues that it is these tactical concerns that bring about the decline of the Holy Roman Empire from the top down; that is, the Empire begins to fail as its imperial dynasty loses faith in its ability to defend itself (or, increasingly, to defend Austria.)

${ }^{8}$ Joachim Whaley, Germany and the Holy Roman Empire, Vol.II, 362.
} 
belonged had already shown itself to be relatively unwilling and, once Saxony had been evacuated by the Prussians, utterly disinterested in Austria's further objectives?

Austria's experience during the Silesian emergencies, and the Seven Years' War, undoubtedly soured the attitude of the Habsburg dynasty towards the imperial crown that it possessed. A renewed focus on the Austrian heartland, on the other hand, would also allow the Habsburgs to focus on the most economically prosperous regions of the Empire, precisely at a time when European markets were becoming increasingly intertwined and important. Austrian provinces, Bohemia and Galicia in particular, were home to a promising agricultural sector. Sweeping reforms of transport and trade infrastructures, including the building of new roads and impressive port facilities at Trieste, elevated Austria to the status of a dependable (if not preponderant) financial power. Vienna, the capital, expanded significantly, and would quickly become the cradle of a nascent industrial and mercantile system easily more successful and lucrative than any other in the Empire. ${ }^{9}$ Under Maria Theresa and, after her death in 1780, her son Joseph II, Austria began a series of extensive reforms, and while these reforms influenced a number of different policy areas, their overall aim was to streamline Austrian commerce and economics, in order to strengthen Austria's economy and, therefore, the state. ${ }^{10}$ Thus, the source of any power the Holy Roman Empire could yield resided firmly within the borders of Austria, and it was

${ }^{9}$ Robert A. Kann, A History of the Habsburg Empire, 181-183.

10 Of some note was Maria Theresa's attempt to reform the education system in 1775 , so as to introduce compulsory elementary schooling, with a specific emphasis on combating illiteracy. In the same year, Vienna introduced a common customs policy encompassing all of Austria (with the exception of Tyrol), a good halfcentury before a similar thing was attempted in Prussia. From 1753, Austrian authorities also began taking censuses in order to make tax collection more efficient. Whaley suggests that one of the few successes of these reforms was that house numbers, which were introduced for the purpose of the census, remained permanently, thus initiating a modern domestic address system in the Habsburg Austrian territories. However, while none of the major reforms achieved total success, we can hardly expect the imposition of modern reforms upon a state heretofore languishing in this sense to be completely successful. The fact remains that the Austrian taxation system became more efficient, education levels were boosted, trade increased, and government expenditure led to the creation of modern infrastructure, often matching or well in advance of Austria's western neighbours. Joachim Whaley, Germany and the Holy Roman Empire, Vol.II, 544-545. For a succinct discussion of Maria Theresa and Joseph II's reforms and their relation to other contemporaneous reform movements, see also H.M. Scott, "Reform in the Habsburg Monarchy 1740-1790", in Enlightened Absolutism: Reform and Reformers in Later Eighteenth-Century Europe, ed. H.M. Scott (Houndsmill: Macmillan, 1990), 145-187. 
Austria in particular - not the Empire as a whole - that would become the more important instrument of Germany's future.

Austria's great rival in extending this influence was a former vassal state of the Empire, the Kingdom of Prussia. Brandenburg, Prussia's heartland in the east, contained little fertile farming ground, suffering as it did from sandy and salty topsoils that precluded crops from growing. Even as late as 1870 , the capital, Berlin, was surrounded by putrid bogs and impenetrable pine forests, and its inhabitants were widely seen to be as primitive as the countryside from whence they hailed. ${ }^{11}$ Voltaire, writing as Europe once again plunged into war in the middle of the eighteenth century, referred to Prussia as "the sandy country of Brandenburg." In spite of this less than auspicious characterisation, Prussia was already wielding power well beyond what its humble origins would have suggested, and Voltaire was left to ponder how. ${ }^{12}$

The source of Prussia's power was not its resources, nor its geography. Instead, its rise to regional power was accomplished through the extraordinary drive of the Hohenzollern dynasty. The royal family seems to have had near limitless ambition, as well as an obsession with guarding the meagre resources at the state's disposal. Having begun as somewhat minor provincial lords, the Hohenzollerns had cultivated a favourable position within the Holy Roman Empire, rising to the rank of imperial electors, before Friedrich I has crowned himself 'king in Prussia' (as opposed to 'king of Prussia', which the Holy Roman Emperor would not countenance) in $1701 .^{13}$

By 1740, Prussia had grown in military, if not geopolitical, power. Its new king, Friedrich II, was a dynamic and genuinely enlightened monarch, a polymath who excelled

11 Geoffrey Wawro, The Franco-Prussian War: The German Conquest of France in 1870-1871 (Cambridge: Cambridge University Press, 2008), 1.

12 Voltaire to Nicolas Claude Theriot, Chêne-Bourg, 26 October 1757, in Voltaire's Correspondence, ed. Theodor Bestermann, Vol.XXXII (Geneva: Institut et Musée Voltaire, 1958), 135.

13 C.A. Macartney, The Habsburg and Hohenzollern Dynasties in the Seventeenth and Eighteenth Centuries (New York: Harper \& Row, 1970), 211-212. 
in musical composition, philosophy and, most importantly for the era, making war. His inspired leadership, which saw Prussia double in size, defeat Austria in the Seven Years' War, and elevate his kingdom to a (contentious) position of a European great power, resulted in his being afforded the title of 'Friedrich the Great.'14 Most significantly, Prussia's annexation of Silesia created for the first time a political counterpoint to Austria within the German sphere and, as we have seen, undermined Austrian confidence in the institutions and efficacy of the Holy Roman Empire.

Through its extraordinary rise through the centuries, Prussia had embraced a position of economic, geopolitical and military strength that, while not necessarily matching that of Austria, at least rivalled it. To contemporaries, it was clear that the immediate future of Germany would be dominated by the question of whether Germany's existence was led by a Habsburg or a Hohenzollern, and Prussia placed itself in direct competition with Austria in that regard. Even approaching the end of his life, Friedrich was able to sway many of the German princes. When, in 1785, Joseph II attempted to trade the sovereignty of Bavaria, the largest of the smaller German states, Friedrich convened the so-called "League of Princes", or Fürstenbund, a consultative body of the leaders of Germany designed to bilk the desire of the Holy Roman Emperor to expand his own territory and power at the expense of others. ${ }^{15}$ While the Fürstenbund was short-lived, its significance should not be ignored. It was, indeed, a coalition of states that followed a cohesive and common policy for defending and safeguarding the sovereign interests of those states. It therefore acted as a rather more effective defensive bloc than the Holy Roman Empire ever had, and while it was not intended to replace the Empire, it served to underscore the apparent split between Austria and its fellow member states. Austrian dynastic interests, it was perceived, had been

14 His subjects in Prussia often fondly referred to him as Alter Fritz - "Old Fritz." King Friedrich II. von Hohenzollern, "Idées sur les projets politiques à former au sujet de la mort de l'empereur", in Politische Correspondenzen Friedrichs des Großen, eds. Johann Gustav Droysen, Max W. Duncker and Heinrich von Sybel, 1.Bd. (Berlin: A. Duncker, 1879), 90-91.

15 Christopher Clark, Iron Kingdom, 217. 
defeated by this unique coalition. This would not be the last time that this would be the motive for pan-German unity.

\section{The Nature of the Smaller States.}

Germany, however, was not merely defined by the dual powers of Austria and Prussia. There were more than three hundred states during the period in question that could be considered (and considered themselves) 'German', and they all had their own peculiar quirks and unique characteristics. The Electorate of Bavaria, in the southeast, was predominantly Catholic, and its royal house, the House of Wittelsbach, enjoyed close ties with the Habsburgs of Austria. Others, such as the Bishoprics of Salzburg, Würzburg or Bamberg, were minuscule religious principalities, led by a prince-bishop and numbering usually no more than a few thousand citizens. ${ }^{16}$ Many 'states' were nothing more than towns that had become the sovereign fiefdoms of local dukes or princes. Germany was also peppered with so-called imperial cities: towns that were autonomous within the borders of other, sovereign states, but under the purview of the Holy Roman Empire itself. There were genuine 'free cities' which governed themselves. The forms of leadership ranged from kingdoms, duchies and regents; in the north, the great port city of Hamburg, with an eclectic population of immigrants and refugees enjoying expansive religious and commercial freedoms, and presided over by an elected republican senate rather than noblemen, quickly grew to become the region's third city, after Vienna and Berlin. ${ }^{17}$

These states differed extensively in their approach to governance, but they were united at least in their commitment to their own political autonomy. Many of the petty princes accepted the patronage of the Holy Roman Empire, or else of other, more powerful

\footnotetext{
${ }^{16}$ Marcel Beck and Heinrich Büttner, Die Bistümer Würzburg und Bamberg in ibrer wissenschaftlichen Bedeutung für die Geschichte des deutschen Osten (Berlin: Weidmannsche Verlagsbuchhandlung, 1937), passim.

17 Hajo Holborn, A History of Modern Germany 1648-1840 (New York: Alfred A. Knopf, 1967), 30-31; Richard J. Evans, Death in Hamburg: Society and Politics in the Cholera Years 1830-1910 (Oxford: Clarendon Press, 1987), 1.
} 
royal houses. This was most commonly expressed in the commissions that many of these princes held in the part-time imperial army of the Holy Roman Empire, or in the Austrian or Prussian armies. ${ }^{18}$ But this did not preclude these states from developing, and jealously guarding, their own unique institutions and heritages. The specific circumstances that brought these about differed from state to state. Nevertheless, up to and even immediately following the Napoleonic era, the hundreds of German states developed their own identities, largely based on their dynasties, and invoking individual bureaucracies, cultural idiosyncrasies, financial institutions, traditions, and other pillars of society that, in their own ways, provided peace, justice, and welfare on behalf of the state apparatus. ${ }^{19}$

The subject of this work, Württemberg, was an altogether unremarkable duchy before 1806 , known more for its relatively advanced constitutional parliamentarianism than anything else. ${ }^{20}$ Württemberg was led by a duke but his power was to some degree limited by the existence of a Landtag, a state parliament, comprised of members of the local estates (Stände). The influence of the Stände on state politics was real enough, as when they were able to oppose (and, soon after, depose) the regent Friedrich Karl in 1692. Württemberg had been a key battlefield for the Thirty Years' War and, like most of the southern German states, it had suffered heavily during that conflict, with recovery coming only gradually. ${ }^{21}$ Württemberg was a state of middling power, middling size, and middling

\footnotetext{
18 Württemberg's Duke Friedrich II, who would become King Friedrich, fought in the Prussian Army under Friedrich the Great. Charles Ingrao, "The Smaller German States”, in Enlightened Absolutism, ed. H.M. Scott, 225-226.

${ }^{19}$ Harm-Hinrich Brandt suggests that these individualist tendencies were so strong in the German states that they ultimately precluded the liberal-nationalists of 1848 from coming to an agreement regarding the unification of Germany in a liberal form. As we shall see in Chapter 5, there were many other factors at play to deny the best efforts of the liberal-nationalists during the 1848 revolutions. Harm-Hinrich Brandt, "The Revolution of 1848 and the Problem of Central European Nationalities", in Nation-Building in Central Europe, 108-109.

20 The Berlin Enlightenment author Friedrich Nicolai once remarked, shortly before the outbreak of the French Revolution in 1789, that the defining characteristic of the Württemberger was his pride in the state constitution, which granted electoral rights unheard of in any other part of Germany. Otto Borst, Geschichte BadenWürttembergs: Ein Lesebuch (Stuttgart: Konrad Theiss Verlag, 2004), 137.
}

21 Peter H. Wilson, The Thirty Years War: Europe's Tragedy (Cambridge, Massachusetts: Belknap Press, 2009), 789. 
economic means, and its experience in the years before the French Revolution and the rise of Napoleon was roughly analogous to Germany as a whole.

\section{German Nationalism before German Nationhood.}

In a popular pamphlet of the late eighteenth century, the Württemberg author and politician Friedrich Karl von Moser argued that Germany would benefit from the education of its constituent princes in national behaviours and sympathies. This was all very well and good, but what was Germany to Moser? Presumably, he equated the Holy Roman Empire with the German nation, since he lamented the gradual dilution of the Empire's power at the hands of upstart Prussia, but even to its admirers, the Empire should not, and indeed could not, be conflated with 'Germany'. It was homogenous in neither a societal nor political sense. Instead, it was an anachronism, a "Ptolemaic system [...] kept in orbit by eccentrics and epicycles."22 The Empire was not the convenient stand-in for Germany that Moser had hoped, but how else could Germany be defined, if not by the Empire?

Germany is a land of few physical borders. In the west, the Rhine seems like an obvious delineator, but at various stages in history both banks of the river have belonged either to France or a German state, and for a large proportion of the remainder it has been a contentious issue. In the south, the Alps are similarly an apparently reliable border, but then one would have to exclude the German-speaking peoples of Austria and Switzerland. In the east, no convenient physical obstacle exists, and in the north the Baltic coast is not so much impenetrable as hopelessly porous, given the interdiction of a variety of the Scandinavian countries - Denmark and Sweden, in particular — into the continental north. The states within this region, to contemporary theorists such as Moser, were German, and bound together in their 'Germanness.' However, it is due to the nature of these fluid borders that

\footnotetext{
${ }^{22}$ Friedrich Karl von Moser, Von dem deutschen National-Geist (Munich: Franz Varrentrapp, 1765), passim; James J. Sheehan, German History, 15; Gerald Strauss, "The Holy Roman Empire Revisited", Central European History 11, 3 (September 1978), 292.
} 
geography was only a descriptor rather than an originator of German nationality. That is, the people inside this German region were to be regarded as Germans, but they were not Germans because they existed inside that region.

So, if Germany could not be readily defined by its geography, perhaps the German nation could instead be defined by its people. This, Moser had attempted to do in 1765 . "We are one people", he declared, "characterised by one name and language, gathered under a single rule, under the same constitution, rights, and obligatory laws, bound to a great common interest of freedom." ${ }^{3}$ In part, Moser had created an "imagined community" of common institutions governed by dynasties, and he based his concept of 'Germanness' on these institutions: linguistics, law, and a dedication to the vague principle of 'freedom. ${ }^{24}$ But what compelled Germans to follow these principles that allowed Moser to call them "one people"?

There was a national consciousness within the German region before the Napoleonic Wars; indeed, it predates Moser's exegesis on the "German national spirit" by over a century. Pamphlets, books, and patriotic poems and lyrics, all appealing to 'Germany' and 'the German', appeared before the Thirty Years' War, and the line "Deutschland über alles", known for being the first line of the Deutschlandlied that would become the German national anthem, dates back at least to the seventeenth century.25 Yet this concept of Germany was not simply a question of institutional convenience; Germans were not Germans simply because they happened to live within the Holy Roman Empire of the German Nation. Even Moser, having extolled the virtues of institutional tradition, now

\footnotetext{
23 Friedrich Karl von Moser, Von dem deutschen National-Geist, 5.

${ }^{24}$ Benedict Anderson, Imagined Communities, 19-22.

25 Wolfgang Burgdorf, “'Reichsnationalismus' gegen 'Territorialnationalismus”, in Föderative Nation: Deutschlandkonzepte von der Reformation bis zum Ersten Weltkrieg, eds. Dieter Langewiesche and Georg Schmidt (Munich: R. Oldenbourg Verlag, 2000), 158-159.
} 
turned on the Empire as the embodiment of this tradition. "[F] or centuries we have been a puzzle of political constitutions", he complained,

prey to our neighbours, the object of their ridicule, extraordinary in the history of the world, disunited amongst ourselves, powerless in our divisions, [but] strong enough to harm ourselves, ignorant of the honour of our name, indifferent to the dignity of the law, jealous of our rulers, mistrustful of one another, separated by principles, violent in their expression, a great and at the same time despised people, potentially happy but in practice regretful unto ourselves. ${ }^{26}$

For Moser, the institutions of empire, regardless of the fact that they theoretically united the German states under a constitutional 'umbrella', did little to advance the cause of German nationalism. Germany and being German was separate, then, to the bureaucracies and administrations of governance, whether that governance was in the name of the German nation or not.

Thus, the key to what made a German German lay beyond the convenience and coincidence of the establishment. In other words, a nation could exist without a state or semi-state structure to support it. Eric Hobsbawm identifies three key identifiers for protonationalism: religion, language, and ethnicity. ${ }^{27}$ Yet, again, these are difficult to reconcile with the Germany of the years immediately preceding (or even after) the French Revolution. For one, while Germany was overwhelmingly Christian (such that the Jews, while playing an important role in German society, constituted only a tiny minority), there was still significant discrepancy among the Christian religious sects. Most of northern Germany, for example, was Lutheran Protestant, while it was widely reported that, as late as 1800, only three Protestants lived in the almost exclusively Catholic Bavarian capital city of

\footnotetext{
${ }^{26}$ Friedrich Karl von Moser, Von dem deutschen National-Geist, 6.

27 E.J. Hobsbawm, Nations and Nationalism since 1780: Programme, Myth, Reality (Cambridge: Cambridge University Press, 2004), 50-79.
} 
Munich. ${ }^{28}$ Almost certainly, this was nothing more than an exaggeration, but the historical schism between Protestant and Catholic Germans was real enough. Animosity between the different branches of German Christianity was not so pronounced as in, for example, the mid-sixteenth century, when a series of devastating fires in Protestant territories in the north were hysterically blamed on the Archbishop of Mainz and other Catholic leaders, but deep divisions still existed. In Bavaria, attempts by the government in the first decade of the nineteenth century to foster tolerance and protection of Protestant churches met with spirited popular resistance, while Lutheran mistrust of Catholic intentions was largely due to a widespread belief that the Enlightenment had bypassed the Catholics entirely, and had been a phenomenon only of Protestant Germany and Europe. ${ }^{29}$ This sentiment was not helped by the devotional Catholic fealty to Rome and the pope, which made Catholic loyalty to a national identity questionable. Much later, after the unification, Otto von Bismarck would launch a "culture struggle" (Kulturkampf) aimed at limiting the political influence of the German Catholics, fuelled in part by his skepticism of Catholic dependability. ${ }^{30}$ In Austria, Catholicism was the norm. In Prussia, the Hohenzollerns were, by and large, Calvinists, and the majority of the population Lutheran. In between these two major states, Germany experienced many variations of the same theme. Religion, therefore, was not a unifying factor.

If Christianity did not unite the Germans into one defined group, neither did language. In his famous hymn Des Deutschen Vaterland (Of the German Fatherland), the nationalist author Ernst Moritz Arndt wrote that, to him, Germany should extend "as far as

\footnotetext{
28 A minority of non-Lutheran non-Roman Catholic populations also existed in Germany, including (but not limited to) Franciscans and Calvinists. Hajo Holborn, A History of Modern Germany, 391; Gerhard Menk, Die Hohe Schule Herborn in ibrer Frühzeit, 1584-1660: Ein Beitrag zum Hochschulwesen des deutschen Kalvinismus im Zeitalter der Gegenreformation (Wiesbaden: Historische Kommission für Nassau, 1981), passim; Paul L. Nyhus, "The Franciscans in South Germany, 1400-1530: Reform and Revolution", Transactions of the American Philosophical Society, New Series, 65, 8 (1975), passim.

${ }^{29}$ Hajo Holborn, A History of Modern Germany, 391; James J. Sheehan, German History 1770-1866, $184-186$.

30 John Breuilly, Nationalism and the State, 341; Jonathan Steinberg, Bismarck: A Life (Oxford: Oxford University Press, 2011), 332-335.
} 
the German language rings, as long as God in Heaven sings." 31 Even this, however, was ambiguous. It is true that, certainly during the sixteenth and seventeenth centuries, the German vernacular developed and spread so that it became the basis of a "linguistic society" (Sprachgesellschaft), which differentiated the states in what was loosely termed 'Germany' from those outside it. ${ }^{32}$ This common ground, however, is misleading. Far from uniting people with a common ethnolinguistic background, language is, as Anthony D. Smith notes, "often irrelevant or divisive for the sense of ethnic community." Smith's examples are instructive: Welsh national identity, for instance, is not hindered by the fact that the southern Welsh generally speak English, as opposed to the Welsh that has remained (or recovered to become) the lingua franca of the north. On the other hand, Serbo-Croat "represents a unified language which affords no basis for two nationalisms", though tensions between Serbian and Croatian nationalism is historically significant, and even today defines parts of the Balkans. ${ }^{33}$ Furthermore, regional dialectic variations transformed German almost beyond recognition. Swiss German, for example, is far removed from the harsh, nasal vernacular of East Prussia. German was the common language of Austria, but the Austrian German taught in schools tended to ignore the linguistic modernisations and reforms standardised in northern German lessons in Germanistik. ${ }^{34}$ In any event, while the language the Austrians spoke was undeniably German, there was enough variation to declare it a dialect of its own, unique to Austria and therefore somewhat distinct from 'proper' German. Even then, significant variations persisted throughout Germany. A Hanoverian or a Hamburger, for example, speak in a profoundly different fashion to a Bavarian speaking Oberfränkisch. The Swabian dialect,

\footnotetext{
${ }^{31}$ Ernst Moritz Arndt, Des Teutschen Vaterland (1814).

32 Wilhelm Kühlmann, "Sprachgesellschaften und nationale Utopien", in Föderative Nation, eds. Dieter Langewiesche and Georg Schmidt, 245.

33 Anthony D. Smith, The Ethnic Origins of Nations, 27.

${ }^{34}$ Ingo Reiffenstein, "Deutsch in Österreich vom 18. bis ins 20. Jahrhundert: Das problematische Verhältnis von Sprache und Nation”, in Föderative Nation, 293-305.
} 
common in Württemberg, is so different from standard Hochdeutsch, that it is the subject of one of the comical fairytales of the Brothers Grimm. In the story Die sieben Schwaben (The Seven Swabians), a hapless band of Swabian adventurers trek as far as the Moselle, where they attempt to ask the locals whether the river can be forded. Unfortunately, their accents are so foreign that the locals cannot understand them, and the leader of the group, Schulz, drowns while attempting to cross. Even worse, his comrades succeed him to a watery grave, because the croaking of a frog is so similar to the Swabian manner of expressing the verb 'to wade' (waten) that they believe Schulz is actually commanding them to follow. ${ }^{35}$ In spite of Arndt's somewhat hopeful identification of language as a unifying factor, the sheer breadth of variation in regional German made it, in some places, almost a completely different language.

The last of Hobsbawm's nationalist differentiator is ethnicity, and here, as with religion and language, the concept is difficult to apply to Germany. ${ }^{36}$ Leaving aside the difficulties of defining a particular German ethnicity, early German nationalists also had to contend with the distribution of Germans, and the inclusion of non-Germans inside what would normally have been considered German territory. East Prussia, for example, was heavily populated with Slavic Poles. A vast number of Slavs, Italians, Czechs and others lived inside Austrian borders. And then, there were sizeable German populations living inside Russian Baltic territories, or in what would, presumably, have been called Slavic lands, excised from the German Fatherland. Austria's territorial interests along the Adriatic and into the Balkans also confused matters; if a nation were to be formed, would Austria be forced to renounce its imperial aspirations? Would Austria even be included, given its extensive multiethnic composition? Certainly, the idea that Austria might not be part of

\footnotetext{
35 Jacob Grimm and Wilhelm Grimm, Kinder-und Hausmärchen, 3.Bd. (Göttingen: Dieterische Buchhandlung, 1843), 185-188.

36 The preeminent discussion of the role of ethnicity in nation-building and nationalism remains Anthony D. Smith, The Ethnic Origins of Nations.
} 
Germany was all but unthinkable, given the large ethnic German population and the institutional heritage of the Holy Roman Empire and the Habsburg monarchy. And yet, such problems of ethnicity seemed insurmountable.

\section{The Revolution and Liberation Wars.}

When France fell into revolution in 1789 , the immediate reaction from a number of German states was not one of alarm. In Prussia, the government saw the deposal of the Bourbon dynasty as an opportunity, both because such a development would cause disquiet in Vienna, and because the Bourbon monarchs were seen as capricious, mercurial, vicious and occasionally dangerous. ${ }^{37}$ The most marked reaction to the storming of the Bastille and the removal of Louis XVI, however, came not in political circles but in intellectual. This was, according to many of the leading German minds of the era, a universal, not just a French, phenomenon, a triumph of philosophy and ideals over the rigid mendacity of the ancien régime. "Oh, it wasn't you, my Fatherland, who climbed to the summit of Freedom to serve as an example for the People", wrote the great poet Friedrich Gottlieb Klopstock, expressing excitement and hope that the Revolution might spread east. "It was France!"38 His Württemberg counterpart, the Tübingen recluse Friedrich Hölderlin, penned a similarly exultant hymn, An die Freiheit (On Freedom), in which he equated the rise of the revolutionary ideals to "the Earth approaching holiness."39

In the beginning, at least, Prussia seemed to have little to fear from the Revolution. The revolt had been against a Catholic monarchy, much of the violence directed at the Catholic status quo of a predominantly Catholic state. Arguably, Berlin was the German

\footnotetext{
${ }^{37}$ Christopher Clark, Iron Kingdom, 284-286.

38 Friedrich Gottlieb Klopstock, "Sie, und nicht wir", in Friedrich Gottlieb Klopstock, Oden, 2.Bd. (Leipzig: 1798), 142.

39 Friedrich Hölderlin, "An die Freiheit", in Friedrich Hölderlin, Sämtliche Gedichte, ed. Detlev Lüders, 1.Bd. (Bad Homburg: Athenäum Verlag, 1970), 118.
} 
great power with the least to fear, since Austria was most of these things, and Prussia was none. For the intellectuals, the opportunity to express and put into practice the new and exciting ideas of the rights of man, freedom of speech and of expression created a heady atmosphere of revolutionary fervour. This was not to last. Friedrich Schiller, the great playwright and Württemberg subject, was fêted in Paris as a "freedom poet", and was made an honorary citizen of the French Republic. Nonetheless, Schiller was suspicious of the Revolution, and feared the war that, he felt, would inevitably result from such upheaval. "I tremble at the prospect of war", he wrote to his friend, the Saxon jurist Christian Gottfried Körner, "for we will feel it in every corner of Germany." 40 In predicting the destructive war, rather than a constructive one, that would envelop Germany and Europe, Schiller was rather more perceptive than Klopstock. The latter remained supportive of the French Revolution until 1799, after which the campaigns of General Napoleon Bonaparte could not be considered anything but offensive actions of conquest. The Terror, the excesses of Robespierre and his ilk, had not broken the old poet's passion for what he saw as the founding of an ideal republic, but for the French to march armies through Europe and into Egypt betrayed their rallying calls of liberté, egalité, fraternité. To his protege, Johann Gottfried von Herder, Klopstock complained: "In what a time we are living! Even a great nation [France] has gone so far as to allow a shameful and pretending freedom to make its appearance." 41

Freedom was soon in short supply for the German states. Napoleon's coup d'etat of 9 November 1799, and his increasing desire for conquest, quickly turned much of the favourable weight of opinion in Germany against the French. The successful French campaigns against the German powers, particularly the crushing defeat of the Austrians at

\footnotetext{
${ }^{40}$ Friedrich Schiller to Christian Gottfried Körner, Rudolstadt, 15 April 1790, in Schillers Briefwechsel mit Körner von 1784 bis zum Tode Schillers, 1.Bd. (Leipzig: Verlag von Veit \& Comp., 1859), 184.

${ }^{41}$ Friedrich Gottfried Klopstock to Johann Gottfried von Herder, 20 July 1799, in Briefe von und an Klopstock: Ein Beitrag zur Literaturgeschichte seiner Zeit, ed. J.M. Lappenberg (Braunschweig: 1867), 404.
} 
Austerlitz in 1805 , and a similarly decisive victory against the Prussian army at Jena in 1806, left the French either directly in control of or exerting influence over most of Germany. At a stroke, the much-maligned Holy Roman Empire was dismantled, Prussia and Austria were made to accept humiliating peaces, and Napoleon reshaped Germany in his own image. Gone were the ineffectual and often-ignored cumbersome legal system of the Empire. Instead, the rule of law was now governed by the Code Napoléon. German states that had sided with France were rewarded with territories annexed from the defeated powers. Some of the defeated states disappeared completely, absorbed into Napoleon's allies. ${ }^{42}$ Among the number of French allies was Württemberg.

The duke of Württemberg, Friedrich II, was an ambitious man who coveted a greater role for his state and himself personally in European affairs. He saw the Holy Roman Empire as an anachronistic blight on his own power, and the French advances along the western banks of the Rhine as an irresistible force. When he was briefly elevated to the role of elector in 1803 , he found the position a further irrelevance, a name on paper for an empire that did not really exist and would surely cease to provide even that pretence. By contrast, the prospects of allying with Napoleon offered much to attract him. With the Holy Roman Empire on its knees, its enclaves and free cities would soon become fair game, and given that Württemberg was pockmarked with these imperial territories, it seemed reasonable that Friedrich might benefit from the Empire's collapse. ${ }^{43}$

Perhaps even more important, however, was the fact that Württemberg would likely suffer if it chose to ally with Austria. By April 1805, Britain had formed the so-called Third Coalition, an uneasy partnership of Britain, Austria and Russia, whose sole purpose was to challenge France for European supremacy. Southern Germany was a logical battleground

\footnotetext{
42 Adam Zamoyski, Rites of Peace, 6.

43 Napoleon apparently thought that Friedrich could be rather cheaply bought, declaring "let him be a king, if that is all he wants!" While circumstances were significantly more complex than this, Friedrich quickly fell into step behind the French. David Gates, The Napoleonic Wars 1803-1815 (London: Arnold, 1997), 19.
} 
for such an endeavour. However, the southern German states were hardly seen to be potential partners in the Third Coalition, and in the absence of consultation from the Coalition members, Friedrich was faced with an uncomfortable prospect. It was more than likely that France would come to blows with some or all of the Coalition within or in the general vicinity of Württemberg. Given the dynastic aspirations of both the Austrian Habsburgs and the Russian Romanovs, it was unlikely that Austria or Russia would guarantee Württemberg's sovereignty and security. On the other hand, Napoleon had much to gain from friendly relations with the south German states. Such relations would offer the emperor of the French a much-needed buffer zone between the First Empire's heartland and the enemy armies of Austria and Russia. Friedrich's first inclination was to declare Württemberg neutral, but this neutrality hardly guaranteed the security he required, and nor did it satisfy his French neighbours. By August 1805 the Bavarian government had bowed to the inevitable and signed a treaty with Napoleon; Friedrich was encouraged to do the same. Eventually, though not without reservations, Friedrich added his signature to a Franco-Württemberg alliance on 5 September $1805 .{ }^{44}$

Friedrich's fears of Austria were apparently well-founded. Austrian troops entered Württemberg from the south shortly after the conclusion of the September agreement, and had soon quartered troops in several towns. Worse, the Austrian government immediately demanded that Stuttgart provide supplies and stores for the soldiers now overrunning much of the electorate. The French responded almost immediately, and on 25 September

\footnotetext{
${ }_{44}$ Much has been made of Friedrich's "betrayal" of the Austrians (or indeed the German nation). It should be noted, however, that the elector did not have much choice in the matter. It is known, for instance, that Napoleon and his foreign minister, Talleyrand, had planned contingencies in case Friedrich did not agree to their proposed treaty. Indeed, Napoleon wrote to Talleyrand on 19 August: "In the matter of the Elector of Württemberg, it seems to me that if the father [Friedrich] decides against us, the easiest thing would be to chase him away, and replace him with his son." Negotiations were actually begun between Napoleon and Prince Friedrich Wilhelm, Friedrich's eldest son, and Napoleon resorted to bribery in some cases: if he sided with the French, the young prince could have his own regiment. He was elevated to the ceremonial position of major-general, and he was awarded the Légion d'honneur. Friedrich Wilhelm appears to have rebuffed Napoleon's attempts to groom him as his father's usurper, but the content of their conversations remains unknown. Paul Sauer, Der schwäbische Zar, 214-217.
} 
crossed the Rhine, engaging Austrian troops in Mühlacker, Freudenstadt, Herrenalb, Liebenzell, Leonberg and Heilbronn, just fifty kilometres from Stuttgart. ${ }^{45}$ Under these circumstances, Friedrich could hardly be expected to sit passively while his state was dismembered by both the Austrians and the French. His negotiations with the French thus focused not on whether Württemberg would be bound by its treaty with France, but rather what form that binding would take. Essentially, then, the French 'rescue' of the electorate from Austrian annexation risked what the Bavarian minister Maximilian von Montgelas termed the "préfecture française" — French hegemony in southern Germany. ${ }^{46}$

Napoleon's terms of alliance would seem to confirm Montgelas' worst fears. Württemberg, the French emperor insisted, would quarter French forces, and would supply its own contingent to the Grand Armée. Württemberg would also be compelled to join a new alliance of Napoleon's creation, the Confederation of the Rhine (Rheinbund). This would be a collection of several Francophile German states, bound by economic policies, the Code Napoléon, and their common treaties of friendship with the French Empire, forming a coalition that would serve as a useful buffer for the French. ${ }^{47}$

The danger in this arrangement was readily apparent. The Rhenish states would be France's first line of defence against the Austrians, the Russians and, if they recovered from their own crippling defeats, the Prussians. Moreover, Napoleon's demands on the Württemberg Army (Heer) were extensive. In 1806, the Heer could field roughly 12,000 men; Napoleon insisted that some 5,500 of them be seconded to his own forces. ${ }^{48}$ Furthermore, though Friedrich sought a promise from Paris to respect Württemberg's sovereignty as an independent state, he must surely have realised that, had such an

\footnotetext{
45 Ibid., 218-220.

46 Erwin Hölzle, “Das Napoleonische Staatssystem in Deutschland”, Historische Zeitschrift 148, 2 (1933), 280.

47 Katherine Aaslestad and Karen Hagemann, "1806 and its Aftermath: Revisiting the Period of the Napoleonic Wars in German Central European Historiography”, Central European History 39, 4 (December 2006), 549.

48 Paul Sauer, Der schwäbische Zar, 220.
} 
undertaking been received, it would have been little more than a transparent fiction. Württemberg's sovereignty had been effectively dismantled the moment Napoleon demanded Friedrich's signature to the Franco-Württemberg alliance, and the Confederation of the Rhine was, by design, nothing more than a French puppet. ${ }^{49}$

Nonetheless, there were also several apparent benefits to Napoleon's proposal. In the first instance, the French agreed that no troops would be quartered in Stuttgart, the state capital, or the House of Württemberg's ancestral home in Ludwigsburg. The French government also offered to reimburse Württemberg in cash for any costs accrued by housing and feeding French soldiers, whereas the Austrians had either refused to pay for goods and services they had seized, or else had paid in imperial paper money that was, by this stage, functionally worthless. Most importantly, Württemberg was offered significant territorial compensation for its support of France. In sum, the larger of the Rheinbund powers - Bavaria, Württemberg, Baden, Hesse-Darmstadt, and Nassau - would gain approximately 65,000 square kilometres of territory expropriated from the collapsed imperial territories or abolished smaller principalities. Württemberg's reward would be, among others, the old Duchy of Swabia, and its territory and population would more than double as a result. Consequently, Napoleon would also bestow upon Friedrich the title of king, and Württemberg would become a kingdom, rather more influential and important than his defunct title of Holy Roman elector. ${ }^{50}$ Ultimately, France's mastery of Europe convinced Friedrich that his only option was to side with Napoleon.

\footnotetext{
49 Enno Kraehe claims that Friedrich was "one of Bonaparte's most reliable allies." The implication of this is misleading; while Friedrich was hardly the most scrupulous monarch of his era, by the time his alliance with France had been concluded he had very little choice but to follow Napoleon's lead. Enno E. Kraehe, Metternich's German Policy, Vol.1, 35 .

50 Hans A. Schmitt, "Germany without Prussia: A Closer Look at the Confederation of the Rhine", German Studies Review 6, 1 (February 1983), 20.
} 


\section{Delusions of Württemberg Grandeur under and after Napoleon.}

Württemberg's new status as a kingdom of the Confederation of the Rhine hardly conferred upon it a preponderant position in European affairs. With a population of only slightly more than 1.2 million, it was hardly a major power, and its importance was undermined by its reliance on Napoleon's French Empire. Almost immediately, Napoleon reneged on many of the promises he had made to guarantee Friedrich's partnership. French troops did not enter Ludwigsburg, but a large contingent was soon garrisoned in Stuttgart, contrary to the 1805 negotiations. Some 80,000 soldiers of the Grand Armée were stationed in Württemberg and Stuttgart soon found to its discomfort that the soldiers followed rules set in Paris, rather than those of their host state. On the orders of the French ambassador to Stuttgart, François Charles Luc de Didelot, soldiers placed the envoys from Austria and Russia under house arrest, despite Friedrich's insistence that this breached Württemberg's sovereignty and its duty towards foreign representatives. Moreover, in spite of France's promise to remunerate Württemberg for the kingdom's quartering of French soldiers, it was Württemberg that was soon required to pay France, in the order of some eight million Francs and 2,000 horses, for service in Napoleon's further campaigns in Europe. More requisitions would follow as Napoleon's campaigns became more and more taxing. 51

The greatest privation, however, was arguably in the human cost. Napoleon had insisted on some 5,500 men of the Württemberg Heer being attached to his Grand Armée, though he had indicated that they would only be used in relatively safe occupation duties, rather than on the front line of his campaigns of conquest. His demands soon ballooned even beyond the ability of the army to achieve. At its peak, the Grand Armée comprised some $600,000 \mathrm{men}$. Of these, at least a third were conscripted from the Confederation of the Rhine, and of these, some 40,000 were Württembergers. In fact, Napoleon's levy on

${ }^{51}$ Kurpfalzbaierische Staats-Zeitung von München, No.CCLIX, 2 November 1805. 
Württemberg manpower was such that any male citizen between the ages of sixteen and forty was liable to be conscripted into the French war machine. Nor were these unwilling soldiers in a foreign army limited, as Napoleon had promised, to 'safe' guard duties. Württembergers were especially active during the ill-fated Russian campaign of 1812, as well as during the Battle of Nations at Leipzig in 1813. Of the 40,000 Württembergers in the Grand Armée, almost 27,000, or roughly sixty-eight percent, were killed between 1806 and 1813.52

Given the treatment of Württemberg by the French, it is unsurprising that Friedrich soon attempted to resist them, or else use the relationship between the empire and the new kingdom to his advantage. Crucially, though, Friedrich's motives varied greatly from those of the intellectuals or of the population in general. Schiller, for one, saw resisting the French as a national endeavour, rather than one bound by states. Other early opponents to French hegemony were even more explicit. Ernst Moritz Arndt and Friedrich Jahn, two of the most prominent contemporary German nationalists, defined German consciousness by opposition. That is, the German was defined by the fact that he was not French, and that the traits characterising French nationalism were despicable, and alien to the German. ${ }^{53}$ Arndt's 1814 battle cry, Des Deutschen Vaterland, insists that the German fatherland, the victim to be rescued by what Arndt saw as a nationwide war of liberation, could be found in Prussia, Austria, Swabia nor Bavaria, but in fact encompassed all states and territories in which German was spoken, and "where any Frenchman is called an enemy." Even the German son in Heinrich von Kleist's Katechismus der Deutschen saw Germany as being defined by its opposition to France. When asked by his skeptical father who his enemy is, the son replies: "Napoleon, and as long as he is their emperor, the French." When his father

\footnotetext{
52 John R. Elting, Swords around a Throne: Napoleon's Grand Armée (New York: Da Capo, 1997), 387; HansJoachim Harder, Militärgeschichtliches Handbuch Baden-Württembergs (Stuttgart: Kohlhammer, 1987), 62.

53 Hans Kohn, "Arndt and the Character of German Nationalism", The American Historical Review 54, 4 (July 1949), 789.
} 
presses him — “is there anyone else you hate?" — his son's reply is forceful and direct: "No one, in the whole world." ${ }^{4} 4$ To these authors and thinkers, the German was obligated violently to oppose the Frenchman, who was his nemesis and the antithesis of what it meant to be German. By implication, that resistance to the French would be for the common benefit of all Germans in all of Germany.

In many of the southern states, the arrival of Austrian troops in the latter years of the wars was greeted with significant nationalist fervour. One widow in the former Austrian town of Villingen, integrated into Baden by Napoleon's machinations, declared triumphantly that "we are imperial again", indicating an eagerness to return to the structure of the Holy Roman Empire, or rather, what the Holy Roman Empire nominally represented: the German nation. ${ }^{55}$ Even the Bavarian king, when he himself turned against the French in the dying stages of 1813, regarded the war against the French as the securing of "the independence of the German nation." 56

By contrast, Friedrich conceived of his circumstances, both in partnership with and against Napoleon, purely as a matter of state, rather than national, affairs. Grasping at any opportunity to aggrandise his state, he apparently saw Württemberg as a prospective regional power. When he had first come to power, as duke in 1797 , he had despaired of his capital. Stuttgart was ugly and uncultured, not the centre of politics and society envisaged by the ambitious Friedrich, who initiated a Residenzbauplan, a redevelopment of the capital into a modern but classically-influenced city fit for the residence of the royal dynasty. At the same time, the great palaces of Württemberg (chiefly, Ludwigsburg, Monrepos and Solitude) were heavily renovated; these efforts continued with great élan after the elevation

54 Heinrich von Kleist, "Katechismus der Deutschen", in Werke und Briefe in vier Bänden, ed. Siegfried Seller, 3.Bd. (Berlin: Aufbau, 1978), 391.

55 Maria Agatha Zimmermann, Tagebuch, 17 November 1813, in Ute Planert, "From Collaboration to Resistance: Politics, Experience, and Memory of the Revolutionary and Napoleonic Wars in Southern Germany", Central European History 39, 4 (December 2006), 688.

56 Michael Döberl, Bayern und die deutsche Erhebung wider Napoleon I. (Munich: Verlag der Königlich Bayerischen Akademie der Wissenschaft, 1907), 403. 
of Württemberg to the rank of kingdom in 1806, and it is significant that the financial resources that made the Residenzbau possible came, for the most part, from French coffers. ${ }^{57}$ Given time, Friedrich felt, he could also make Württemberg a military power of some standing. Thus, when Württemberg laid claim to Swabia and other Holy Roman territories, the new king confidently predicted that his tiny Heer could be expanded to over 30,000 soldiers. With that, he could surely protect, or regain, the sovereignty of his kingdom. ${ }^{58}$ In fact, Friedrich would be thwarted by Napoleon's increasing demands on Württemberg to supplement his Grand Armée.

Perhaps the most important act, though, was not what Friedrich did, but what he did not do. The Confederation of the Rhine, in Napoleon's conceptions, would be a federal power under France's 'protection.' In expanding the territories and prestige of his German allies, however, Napoleon had offered them a taste of larger-power sovereignty. Württemberg had always been a minor player in German affairs, but now, having doubled in size, its position was rather more important. The same was true of Baden and Bavaria, Württemberg's two most important neighbours. Having found themselves in possession of larger, more powerful, and more lucrative territories than ever before, the royal houses of these states — the House of Württemberg, Wittelsbach in Bavaria, Zähringen in Baden — were unwilling to dilute this newfound power by unifying as an instrument of French foreign policy. These powers dragged their heels on the establishment of the "fundamental statute" that would formalise the Rheinbund.59 As a result, the Confederation existed in name, but while these middle-states were bound to one another by the will of the French emperor, the constitution that would make this a de jure relationship simply did not exist.

\footnotetext{
57 Jürgen Hagel, Stuttgart im Spiegel alter Karten und Pläne (Stuttgart: Katalog der Ausstellung des Hauptstaatsarchivs Stuttgart, 1984), 43.

58 Paul Sauer, Der schwäbische Zar, 221.

59 Hajo Holborn, A History of Modern Germany 1648-1840, 371-372.
} 
The reluctance of the Mittelstaaten to tie themselves to the Rheinbund may also have reflected a shift in public opinion away from the French themselves. In the main, the French had generally been viewed with cautious respect to begin with. One contemporary history refers to the "high opinion of [the French] character, which he had already established through all of Swabia at the time of the first invasion."60 The Stuttgart publisher Johann Cotta was still impressed with Napoleon almost three years after he had elevated Württemberg to a kingdom, and in letters to Goethe insisted that Württemberg's ties with France would lead to more pronounced political liberalism. ${ }^{61}$ However, much like the retreat of other German intellectuals, such as Klopstock and Schiller, Württembergers and south Germans in general grew more suspicious of the French as the authoritarian brutality of Napoleon's empire became more and more apparent. Consistent, overwhelming demands on Württemberg's resources bankrupted the state, and the economic hardships, not to mention the devastating effect of conscription, caused citizens to riot in protest. ${ }^{62}$ Cotta himself, having finally woken to the nature of the French and the ruin that the alliance would bring, took to shuttling letters in secret between Stuttgart and Vienna, hoping to negotiate a settlement with the resurgent Austrians. ${ }^{63}$

This violent change in public opinion did not go unnoticed by King Friedrich. In 1813, writing to his foreign minister, Count Ferdinand Ludwig von Zeppelin, he lamented: "The return of the officers, more and more of the sick and wounded, cripples, and those unfit for service, [...] daily stokes a great voice [of protest]." He recorded the "distaste" of "everything that is French", and he warned Zeppelin that "one is beginning to hear, from

\footnotetext{
${ }^{60}$ Johann Gottfried Pahl, Denkwürdigkeiten zur Geschichte von Schwaben während der beyden Feldzüge von 1799 und 1800 (Nördlingen: Karl Gottlob Beck, 1802), 139.

${ }^{61}$ Johann Friedrich Cotta to Johann Wolfgang von Goethe, 16 November 1808, in Monika Neugebauer-Wölk, Revolution und Constitution. Die Brüder Cotta: Eine biographische Studie zum Zeitalter der Französischen Revolution und des Vormärz (Berlin: Siedler, 1989), 347.

62 Ute Planert, "From Collaboration to Resistance", 685-686.

${ }^{63}$ Enno E. Kraehe, Metternich's German Policy, Vol.1, 232.
} 
different districts throughout the land, calls to the people, in which one speaks of liberation from the yoke." 64

The enormous losses at the Battle of Nations at Leipzig in October were the last straw. By December, Friedrich had instigated extraordinary tax legislations, not with the aim of providing Napoleon with the means to wage war but in fact as a means to raise his own 'army of liberation' against the French. In this manner, Friedrich was following the lead of the Bavarians, who had only slightly earlier declared their intention to leave the Confederation of the Rhine and fight on the side of the Sixth Coalition. Baden also followed suit. These three southern states were in a fortunate position to be able to do so. The 80,000-strong French garrison who had originally arrived in Württemberg in 1805 had, over the years, been whittled down to 10,000 , and even these paltry few had been poached for duty in Russia and at Leipzig. Thus, when Friedrich raised a liberation army some 12,000 strong, under the command of his son, Crown Prince Friedrich Wilhelm, he was almost totally unopposed. ${ }^{65}$ By contrast, Saxony, Bavaria's neighbour to the north, was home to a large French garrison, and when the Saxon King Friedrich August attempted to evict them, the French responded by deposing and imprisoning him. Thus, when Napoleon was eventually deposed, the Württembergers were partners of the victorious allies, while Saxon diplomats arrived for the postwar peace conference in Vienna in September 1814 as representatives of a defeated enemy power. This, in addition, would differentiate the treatment of Württemberg, Baden and Bavaria from Saxony; while Württemberg consolidated its Napoleonic territorial gains, Saxony suffered territorial losses to Prussia.

It is also notable that the southern states did not act, either during the war or after, in conjunction with one another. Instead, they followed their own independent paths towards peace and negotiations. It was for this reason that Friedrich was confident enough to

\footnotetext{
${ }^{64}$ Paul Sauer, Der schwäbische Zar, 313.

65 Ute Planert, "From Collaboration to Resistance”, 690-691; Paul Sauer, Der schwäbische Zar, 401.
} 
approach the powers at the Congress of Vienna with a proposal that Württemberg should also annex eastern territories belonging to the Grand Duchy of Baden, though it is no surprise that these plans quickly fell through. ${ }^{66}$ Baden and Bavaria, in the meantime, would squabble over territory for the better part of fifty years. Thus, even when a common cause united them, none of the south German states would risk their sovereign independence through closer cooperation, which may have been seen as the beginning of state-sanctioned German nationalism. Friedrich acted not in solidarity with his fellow southern German monarchs, but out of fear of the Austrians, suspicion of the Prussians, and his own deeply particularist interests at heart. He aimed to expand his fiefdom, and his gains would be solely in the interests of his own state, rather than Germany as a whole.

\section{Beginning a New German Era.}

The Germany of the Revolutionary and Napoleonic eras was one fraught with crises of identity. A great many German minds, not to mention the population in general, viewed the ideals of the revolution with significant interest and no small amount of enthusiasm. Why this was so is difficult to explain. For many, the promise of liberalism was equated with profound opportunities for German nationalism. Enthusiastic pan-Germanists, such as Klopstock, Hölderlin and Cotta, embraced the revolution, presuming that the ideal of fraternité, in particular, would foster a liberal, universal German identity, with which a nation might be forged. Others were not so enthusiastic. Goethe rarely expressed his opinions on the Revolution, while his colleague Schiller saw it not as a liberating force, but rather a destabilising element, one that would potentially lead to war and devastation for Germany. Schiller saw Germany's future as being furthered resisting the Revolution rather than embracing it. Similar thoughts were expressed by Kleist, Arndt and Jahn, who saw the intervention of France in German affairs not as a liberating influence, but as that of a

${ }^{66}$ Paul Sauer, Der schwäbische Zar, 415. 
meddlesome nemesis; it was the duty of all Germans, they argued, that this nemesis be violently repulsed. Ultimately, this was a view shared by even the greatest of the early German supporters of French intervention.

By and large, however, these nationalist sentiments were not reflected in the policies of the various German governments, and German nationalism was, certainly throughout the early years of the Revolutionary and Napoleonic Wars, immature and prototypical. Many states, such as Württemberg, acted in their own, narrowly-defined state interest, hungrily grasping at the discarded territories of the failed and defeated German states, and allying themselves with the French when it seemed that such a move might be of material benefit. Nationalist conceptions did not enter the equation in the public policy of Württemberg. Friedrich acted pragmatically, siding with France when such a manoeuvre seemed advantageous, but defecting to the side of the Sixth Coalition once it became clear, firstly, that Württemberg was suffering from its continued relationship with France, and secondly, that France would almost certainly be defeated by the allied powers.

The Napoleonic years set the scene for what would be half a century of German national development. It is, therefore, vital to understand the influence of the Napoleonic Wars on the German states in general and, for the purposes of our study, Württemberg in particular, for it was the circumstances of these years that led to the German states precariously attempting to balance national and state interests. Napoleon's Rheinbund had introduced the concept of the Mittelstaaten, and these states had spent the better part of seven years determining their position in Germany and Europe, and the extent and limits of their powers. The wars and their aftermath consolidated the reality that there were two major powers in Germany, being Austria and Prussia, and their respective influences over Germany would be vital for the future in the region. It also established that cooperation between the Mittelstaaten, while unfulfilled in deed between 1806 and 1813, was certainly possible. This, after all, was the entire raison d'etre of the Mittelstaaten. Finally, in spite of 
the fact that the Mittelstaaten were specifically designed to be incapable of existing independently, the actions of the governments of these states - and in particular, the actions of the government in Stuttgart - demonstrated that they were at least willing to attempt to operate autonomously of any larger state or collection of states. How these four elements the influence of Austria, the influence of Prussia, potential political cooperation between the Mittelstaaten, and the particularist desires of the smaller states - developed in the aftermath of the Napoleonic Wars is the subject of the next three chapters. 



\section{CHAPTER 2 \\ STUTTGART AND VIENNA BEFORE 1848}

IN THE IMMEDIATE postwar years, Austria quickly emerged as the strongest of the German powers. It was Austria that hosted the Congress of Vienna, the peace conference that would determine the shape and direction of Europe now that Napoleon had been defeated. It was also Austria that took the lead in German affairs, guiding the formation of a new conglomeration of states, the German Confederation, and determining its legislative guidelines, in the form of the 1819 Karlsbad Decrees. In a sense, then, Austria was Germany's stepfather. Vienna intended to steward the smaller states into the modern era; they, in turn, should model themselves upon Austrian rules, regulations and conventions. That the member states, the 'children' of the Confederation, should develop individually, albeit under the watchful eye of their guardian, was a given.

Yet Vienna also feared that, like all adolescents, the German children would rebel. The Karlsbad Decrees, which suppressed German nationalist movements and introduced stringent press censorship within the confederal states, are evidence that the German Confederation was conceived as a reactionary, controlling measure, rather than the first step in a national unification. ${ }^{1}$ However, while Austria was often viewed favourably by the smaller states, including Württemberg, it is also true that the intentions of Metternich and his successors did not always converge with those of the power-brokers in Stuttgart, Munich, or Karlsruhe. What resulted, throughout the first half of the post-Napoleonic century, was a political game of brinkmanship, in which the leaders of the Mittelstaaten attempted to eke away at Vienna's control of affairs, without alienating their powerful neighbour. In the case of Württemberg, periods of cooperation were punctuated by brief spurts of covert, and sometimes open, antagonism.

\footnotetext{
${ }^{1}$ Wolfgang Renzsch, “German Federalism in Historical Perspective”, 18-19.
} 


\section{Post-Napoleonic Origins of Austrian Hegemony in Germany.}

Austrian fears of a rebellious movement of smaller, German states, and in particular the more powerful Mittelstaaten, were not entirely unfounded. For centuries, the tiny principalities of central Germany had been weak states that relied on their southern neighbour for protection from external threats. Württemberg had been one of those weak powers; on the eve of the French Revolutionary Wars, the then-duchy had no standing army, crumbling military institutions, and a complete inability to fend for itself in the face of war with its increasingly restless French neighbour. ${ }^{2}$ This theoretically provided Austria with a buffer of friendly but dependent states to its north; in practice, the varying demands on Austria to defend Germany militarily stretched it beyond its ability. Since Maria Theresa's rule, Austria had become suspicious of its obligation to defend the realms of the Holy Roman Empire, especially when the client states of that empire proved to be less than dependable. Such was the case once Napoleon began his march through Germany; when the smaller states found themselves directly under the threat of a foe more powerful than their protector, many of them chose to align themselves with the French. But the change in circumstances in Germany was not limited to Austrian ambivalence towards their onceallies. Time and again, Austria had been challenged and beaten on the battlefield, and it was only thanks to an overwhelming force of arms, allied with Britain, Russia, and Prussia, that Vienna emerged from the wars, battered but victorious, in 1815. By contrast, the system of smaller states that had once been so dependent on Austrian patronage had been streamlined by Napoleon's sweeping territorial reforms. Gone were the hundreds of petty principalities wielding no power to speak of. Instead - certainly for the larger of the Mittelstaaten, such as Bavaria, Saxony, and Württemberg - populations now numbered in the millions, and with this expansion came a greater potential to raise larger, standing

\footnotetext{
2 Paul Sauer, "Die Neuorganisation des württembergischen Heerwesens unter Herzog, Kurfürst und König Friedrich (1797-1816)”, ZWLG 26 (1967), 395.
} 
armies, as well as a larger workforce generating greater income for the state. On the eve of the Napoleonic Wars, Austria had been capable of managing Germany because Germany was comprised of minnows. In the aftermath of the wars, at the very least Austria was to discover that they had teeth.

The increase of geopolitical weight attached to the Mittelstaaten also corresponded with a decline in Austrian prestige. The disastrous defeats at Ulm and Austerlitz (1805) had not just forced Austria to renounce the Holy Roman crown and dissolve the Empire. In material terms, the Austrian Army had been severely weakened, such that it was not able to take to the field in any meaningful capacity for close to a decade. The public image of Austrian militarism also suffered; during the war, some southerners rejoiced at the "imperial" liberation of their home towns, but Napoleon had shown the Austrians to be beatable, and the reluctance of Vienna to commit its forces to battle also acted to its detriment. ${ }^{3}$ It was not, after all, the Austrians who took to Waterloo to defeat Napoleon once and for all. That task had been left to the British and Prussian armies of Wellington and Blücher.

The weakening of Austrian resolve, and the perception of Austria, had one particular significance. Incapable of relying on Austria, an increasing number of people within the German states began to engage with the discourse of German nationalism. As we have seen, this had previously been the purview of philosophers, artists, and princes. But the uncertainty of the times, and the undermining of competing regional identities, acted as a catalyst for the explosion of popular pan-German nationalist sentiment.

The radical redrawing of the boundaries of the German states in 1805 had a profound impact on the concept of state identity. Generally, there was a sense of "territorial patriotism" (Territorialpatriotismus) that existed in most of these states. So, for example, a

\footnotetext{
3 See, for instance, Maria Agatha Zimmermann, Tagebuch, 17 November 1813, in Ute Planert, "From Collaboration to Resistance", 688.
} 
citizen of the Duchy of Swabia often had, to some extent, a loyalty to Swabia, and an intellectual understanding, however undeveloped that might be, of what it meant to be Swabian. Admittedly, other forms of identity, separate from geopolitical distinctions, often took precedence. A Lutheran milliner from Bayreuth who spoke the Upper Franconian dialect, for instance, was likely to define himself by his religion, his trade, his region or town, or his language, more than he would be defined by the state that governed him. The diary of Jakob Walter, a Ludwigsburg Catholic who was part of the Heer contingent suborned to Napoleon's Russian campaign, reflects the typicality of this. Returning wounded from Russia, Walter expressed his relief at entering largely Catholic Saxony, which to him felt "more German." By contrast, Stuttgart, the capital of his home state, offered him little of interest; upon returning to Ludwigsburg, and surrounded by fellow Swabian Catholics, he conversely felt most at home. ${ }^{4}$

Territorialpatriotismus played a relatively minor role compared to the confessional, professional, and regional identifiers, but it was nevertheless a consideration. One anonymous correspondent, writing in the influential journal Allemannia in 1815, expressed his skepticism of pan-German nationalism, declaring that the central social unit was the particular state. One could be German, he argued, but first one would have to be "Prussian,

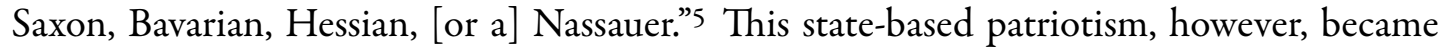
more problematic once more than three hundred states had been dissolved and integrated into the Mittelstaaten. Jakob Walter considered himself a Swabian, but Swabia as a geopolitical entity no longer existed. The same could be said of the citizens of Würzburg, Augsburg, and Bamberg, which had all been ceded to Bavaria, or countless other small states that had become components of Baden, Saxony, or the Hessian states. Thus, many Germans found themselves belonging to states for which they had no sense of

\footnotetext{
${ }^{4}$ Jakob Walter, Diary of a Napoleonic Foot Soldier (New York: Penguin, 1993), 105-111.

5 "Ueber die teutschen Gesellschaften", Allemannia 1, 1 (January 1815), 277.
} 
Territorialpatriotismus; a Swabian who found himself, virtually overnight, to now be a citizen of Württemberg was, after all, unlikely immediately to transfer his loyalty to Württemberg. Nor could he appeal to an identity that no longer existed.

The natural consequence of this vacuum of identity was that the disenfranchised populations of Germany began to resort to a unitary form of identity that had not changed with the redrawing of borders. In the absence of the state to which they owed their first patriotic duty, as Humboldt would have it, these people instead began to identify with the overarching descriptor: if they could not be Swabians or Bambergers or Würzburgers or Imperial Reutlingers, at least they could be - and remained - German. In this fashion, the ideas of Goethe, of Schiller, of Arndt and Kleist and Jahn, began to influence and, in turn, be influenced by a wider, popular engagement. Overt displays of nationalism found their voice in organisations such as the Burschenschaften student unions, which dotted Germany and used the platform of radical student politics to demand political and social reform along national lines. Elsewhere, particularly in Prussia, gymnastic associations also played an extensive sociopolitical role that well outstripped their status as sporting and educational institutions. ${ }^{6}$

Such developments were viewed as dangerous by the Austrian minister-president, the energetic and deeply reactionary Prince Clemens Wenzel Nepomuk Lothar von Metternich. Austria's interests were largely predicated on developments in Germany; as Austria's closest neighbours, the German states were most likely to be the source of future security concerns. Yet here, Metternich faced two conflicting forces that combined to confuse and threaten Austrian German policy. On the one hand, the smaller states were now large enough to have some diplomatic weight of their own, and certainly enough to

\footnotetext{
${ }^{6}$ Rolland Ray Lutz, "'Father' Jahn and his Teacher-Revolutionaries from the German Student Movement", The Journal of Modern History 48, 2 (June 1976), 1-34. Brian Vick also places Jahn, Arndt, and the Burschenschaften within an ethno-nationalist framework, as opposed to a sociopolitical one. Brian Vick, "The Origins of the German Volk: Cultural Purity and National Identity in Nineteenth-Century Germany", German Studies Review 26, 2 (May 2003), 241-256.
} 
mount a defence of their own particular interests if these did not correspond to Austria's. On the other hand, the developing and resurgent German nationalist movement now had a more expansive, popular dimension. There were dangers associated with this popular engagement with nationalism. The concept of a German universal brotherhood sounded disturbingly similar to the rhetoric of Revolutionary France, and many European diplomats feared that the rise of a new German power would fill the vacuum left by the fall of Napoleon's empire. ${ }^{7}$

German nationalism also appeared to be violent, dangerous, and revolutionary in character. In Baden the fragile political system nearly dissolved into armed insurrection or civil war on several occasions in the years between 1815 and 1819.8 Nationalist demonstrations often degenerated into riots, and violence and murder were not uncommon. An infamous example was the assassination of the playwright August von Kotzebue, a vocal opponent of German liberal nationalism, by the student activist Carl Ludwig Sand in 1819. The Kotzebue affair was only the most notorious of the endemic criminal outrages spreading throughout the German hinterland after the Congress of Vienna. That same year, most of the German states were paralysed by a series of riots, ostensibly antisemitic but part of a wider campaign that demonstrated national discontent over years of hardship and a lack of a unified German policy to combat these social ailments that seemed to afflict?

The social and political disorder exemplified by Kotzebue's murder proved to be the breaking point for Vienna. It provided Metternich with a pretence to introduce the reactionary Karlsbad Decrees, aimed at suppressing the liberal movement and outlawing

\footnotetext{
7 Steven Ozment, A Mighty Fortress: A New History of the German People, 100 B.C. to the 21st Century (London: Granta, 2005), 163.

${ }^{8}$ Loyd E. Lee, "Liberal Constitutionalism as Administrative Reform: The Baden Constitution of 1818”, Central European History 8, 2 (June 1975), 92.

9 Richard Tilly, "Popular Disorders in Nineteenth-Century Germany: A Preliminary Survey", Journal of Social History 4, 1 (Autumn 1970), 15.
} 
the Burschenschaften to which radicals such as Sand belonged. ${ }^{10}$ To Metternich and the Austrian crown, nationalism was indelibly linked to violence and unrest, and the murder of the popular author was an example of this danger. At least to some, however, the defeat of Napoleon created an expectation that the Empire would indeed be resurrected. This was a prospect that they, being displaced after the forcible and sudden contortions of the German territories, greeted with the enthusiasm of being part of a greater and familiar whole. In essence, even if the territorial changes could not be revoked, and even if the borders could not be once more redrawn, they would be citizens of an Austrian-led Germany, and not of a Stuttgart-led Württemberg, a Munich-led Bavaria or a Karlsruhe-led Baden. ${ }^{11}$

This popular sentiment, however, did not reflect the desires of the Austrian court at the Hofburg in Vienna. Metternich conceived his conglomerate of German states to be a loosely governed federation. At its heart would be a Federal Diet to meet in Frankfurt. The Diet would have a president, and representatives of each state, but it would not act as an omnipotent, pan-German legislative body. The German Confederation would be therefore merely an advisory body of state representatives, answerable to their own sovereigns rather than to the Diet as a whole. There would be no German emperor, not even in name alone. Not only were the nationalists' hopes for a returned imperial Habsburg rule based on an idealised sense of past unity. They were now nothing but unrealised dreams, and certainly did not satisfy the lust of a large proportion of southern Germans to forge and belong to a widely-encompassing national identity that could define them in a manner in which their new state identities could not. ${ }^{12}$

\footnotetext{
10 F. Gunther Eyck, "The Political Theories and Activities of the German Academic Youth between 1815 and 1819”, The Journal of Modern History 27, 1 (March 1995), 27.

11 Ignaz Speckle, Das Tagebuch von Ignaz Speckle, Abt von St. Peter im Schwarzwald, 23 November 1813, 2.Bd. (Stuttgart: Kohlhammer, 1966), 439.

12 Ute Planert, "From Collaboration to Resistance”, 705.
} 


\section{Stuttgart and Vienna's Strained Relations.}

Against this background of changing politics and relations, the Kingdom of Württemberg found itself in an unenviable position. Stuttgart may have changed sides late in the Napoleonic Wars, but its earlier friendship with Paris had not been forgotten by the other victorious Alliance powers. At the Congress of Vienna, Württemberg was often in danger of being dismembered, as a result of Prussia's harsh postwar demands. In return for turning on the French, Friedrich had been promised territorial expansion by Metternich, but circumstances at the end of the war had denied Württemberg this opportunity. Faced with Prussia's demands, Austria struggled just to maintain Württemberg's current territorial integrity. At the same time, Württemberg had done little to guarantee Austria's favourable patronage during peace negotiations in 1813 and after, and Friedrich had resorted on more than one occasion to appealing directly to Tsar Alexander for Russian support, which raised Vienna's fears that St. Petersburg would gain a toehold in the German heartland. ${ }^{13}$ In particular, Friedrich wished to avoid the dilution of his own power, which had been successfully expanded under Napoleon's influence, and was now in danger of being lost by Württemberg's membership of a confederation of the states - no matter how weak that confederation might be. Friedrich, however, had overplayed his hand; Alexander may have had dynastic ties with Württemberg, but risking protracted diplomatic tensions between himself and the Hofburg was not on his desired agenda. Friedrich delayed in accepting the proposed postwar settlement and the creation of the German Confederation, hoping that the Russians would come to his rescue; when that did not happen, and in spite of calling the Confederation an "absurdity" and "fraudulent", he ultimately had little choice but to accept its existence and his state's membership. ${ }^{14}$ As a result, on 1 September 1815

\footnotetext{
${ }^{13}$ Enno E. Kraehe, Metternich's German Policy, Vol.I, 232-233.

${ }^{14}$ King Friedrich I. von Württemberg to Baron Heinrich Karl Friedrich Levin von Wintzingerode, Ludwigsburg, 10 May 1815, in Albert Pfister, Aus dem Lager der Verbündeten 1814 und 1815 (Stuttgart: Deutsche VerlagsAnstalt, 1897), 340.
} 
Friedrich instructed his envoy to the confederal negotiations, Baron Heinrich von Wintzingerode, to accept the terms of membership and thus end Württemberg's brief period of official particularist irredentism. ${ }^{15}$ So, while Württemberg had expected to share in the glory of victory, it instead faced an uncertain fate, and Austria's support was not without conditions that Stuttgart viewed unfavourably. Württemberg thus had every right to view the German power-brokers with some suspicion.

When Friedrich died in 1817, he was succeeded by his son, Wilhelm. Wilhelm was a significantly different political animal compared to his father. Friedrich had acted in every way to embolden and benefit his own kingdom, even when such actions were dangerous and unpopular. His vacillations in the confederal negotiations of 1815 had done little to make him popular with the far more powerful Metternich, and his previous appeals to the Russian court achieved little except to arouse Austrian suspicions. Wilhelm, however, had led Württemberg's contingent in the (somewhat) united German effort against the French during the post-Leipzig campaigns. He had fought alongside Bavarians, Badenese and Austrians, and he was convinced that cooperation between the German powers was vital. Indeed, the nationalist demonstrations in Stuttgart, Ludwigsburg and other Württemberg towns were left relatively unmolested by Wilhelm's authorities. In other states, the movements were frequently and ruthlessly suppressed. Wilhelm's introduction of a liberal constitution in 1819 similarly offered a degree of political freedoms unheard of in any other German state barring Baden. The crown, while perhaps not actively encouraging a popular German nationalist discourse, certainly permitted it, and this would continue in spite of the Karlsbad Decrees placing strict limitations on the German press.

Partially, of course, this is at the crux of the difficult post-Federician relations between Austria and Württemberg. On the one hand, Friedrich's obstinate delusions of

\footnotetext{
15 It is hard not to feel sorry for Wintzingerode, who enjoyed good relations with Metternich but was subjected to the (it must be said) unreasonable demands of his own sovereign, and was required to present these demands to his Austrian counterpart. Albert Pfister, Aus dem Lager der Verbündeten 1814 und 1815, 344.
} 
grandeur, which had caused Metternich (not to mention Wintzingerode) significant problems, gave way to the pan-German sympathies of his energetic son. The changing of the guard hardly made the state's relationship with the Hofburg any easier. Instead, the nature of the problem had changed. Wilhelm's constitution, introduced on the eve of the Karlsbad Decrees, was designed from the outset to undermine Metternich's reactionary tendencies. Chief among its tenets was that the state constitution would take precedence over any undertaking of the German Confederation. In this way, Wilhelm was able to legally sidestep the more repressive elements of Austrian German policy; indeed, Wilhelm expected the other German states to act in kind. ${ }^{16}$ When it had become clear that the other smaller states would not follow suit, in 1820 Wilhelm attended a conference of the Confederal states, to propose the first steps in a form of closer cooperation between the Mittelstaaten. This was designed as a necessary, preliminary step towards unification. Once more unsuccessful, Wilhelm suffered a further embarrassment; his state was heavily censured by both Austria and Prussia for agitating against the loose status quo, and both powers recalled their consular officials from Stuttgart. To Wilhelm, this determined once and for all that the Austrian crown had set itself against German unity, and since unification had proven itself a popular rallying cry for the German people, the Württemberg king found this attitude both blind and naïve. After all, how could the Habsburg monarchy deny the obvious groundswell of German nationalism that had been demonstrated through the violent actions of the troublesome Burschenschaften?

Metternich had his reasons for suppressing a German national movement. In spite of the fact that he was born in the Rhineland rather than Austria proper, and regardless of his circuitous route to power, the Austrian minister-president was cut from the same cloth as his seventeenth-century counterpart Hörnigk, and his conception of power tallied with the

\footnotetext{
16 Walter Grube, Der Stuttgarter Landtag 1457-1957: Von den Landständen zum demokratischen Parlament (Stuttgart: Ernst Klett Verlag, 1957), 501.
} 
precepts of Maria Theresa and Joseph II. ${ }^{17}$ That is, he saw the integrity of the Austrian heartland as the most vital step in safeguarding Austrian interests in Europe. The way to this goal was twofold: Austria would promote a solution to the difficult issues facing Germany that would secure a general and lasting peace, but Austria would not entangle itself directly in matters of state. In other words, Austria's answer to the German Question was to try to avoid answering altogether. ${ }^{18}$

Metternich saw his opposition to German liberal-nationalist movements and his reactive German Confederation system as a way of maintaining Austrian dynastic integrity while securing peace. Certainly, it met with some approval abroad. In private conversations with the British ambassador to Vienna, Charles W. Stewart, Metternich laid out his plan for the "Germanick Confederation." "His Highness' impression with regard to this Body", Stewart wrote later to his foreign secretary, Viscount Castlereagh, "is to give it as little as possible a political Attitude, that it should be as much as possible confined to its administrative functions." In this fashion, Stewart continued, Metternich hoped to avoid "the same focus for Intrigue [...] as formerly existed in Ratisbon." 19 On this matter, Stewart urged Castlereagh to "open Yourself to the Austrian Ambassador" and thereby clarify Britain's support for Metternich and his program for Germany. ${ }^{20}$ In turn, Castlereagh replied to Stewart a fortnight later; praising the ambassador for the "clear and satisfactory manner in which you had executed my Instructions", he assured Stewart that "upon all great Principles of European Politicks [sic.], the British and Austrian Gov[ernmen]ts are

\footnotetext{
17 An excellent account of Metternich's early years and his rise to power can be found in Enno E, Kraehe, Metternich's German Policy, Vol.1, passim.

18 James R. Sofka, "Metternich's Theory of European Order: A Political Agenda for 'Perpetual Peace”, The Review of Politics 60, 1 (Winter 1998), 115.

19 Ratisbon, or more properly Regensburg, was the seat of the Holy Roman Empire's Imperial Diet, which had become increasingly irrelevant over the course of the Empire's existence. Thus, Metternich's message through Stewart was to suggest that the looser, less political arrangement of the German Confederation would avoid the inefficiencies, contradictions, and pitfalls of the old Empire's political system.

${ }^{20}$ Charles W. Stewart to Robert Stewart, Viscount Castlereagh, No.51, Vienna, 23 June 1816, in British Envoys to Germany, Vol.I, 458-459.
} 
agreed."21 Whitehall, therefore, was happy to see Metternich opt for a system designed to allay the 'risk' of German unification. Its approval of Metternich's German policies continued into 1819, when the decrees banning the Burschenschaften and muzzling the German nationalist presses were signed. "There is no doubt that Prince Metternich has evinced singular judgement and ability upon this late occasion", Stewart declared on 1 October of that year, shortly after Metternich had returned from Karlsbad.22

To many German nationalists, however, Metternich's policies constituted nothing short of a betrayal of the German people, who had turned to Austria seeking unity and political salvation. ${ }^{23}$ Even those who had been cautiously optimistic about the German Confederation were now left disenchanted by the suppressive nature of the Karlsbad Decrees. In Württemberg, as in the other member states, the decrees caused "a considerable sensation"; Sir Brook Taylor, the British minister to Stuttgart in October 1819, observed perhaps with some irony - that this "sensation" would be muted because "the measures which have been adopted [in accordance with the Karlsbad agreement] to check the liberty of the Press will for the present prevent any public manifestation of discontent or complaint." 24

The press may not have been at liberty to criticise the crackdown on liberalnationalist sentiment, but this censorship did not extend to the top of the state political hierarchy. King Wilhelm, as we have seen, was skeptical of the Confederation, and Karlsbad confirmed his belief that Austria was acting for itself and not in the interests of Germany as a whole. Indeed, he did attempt to resist the Confederation's adoption of the decrees, by

\footnotetext{
${ }^{21}$ Robert Stewart, Viscount Castlereagh to Charles W. Stewart, Foreign Office, London, 9 July 1816, in British Envoys to Germany, Vol.I, 460-461.

22 Stewart to Castlereagh, No.1, Vienna, 1 October 1819, in British Envoys to Germany, Vol.I, 490.

23 Roy A. Austensen, “'Einheit oder Einigkeit?' Another Look at Metternich's View of the German Dilemma”, German Studies Review 6, 1 (February 1983), 44; Peter Viereck, "New Views on Metternich", The Review of Politics 13, 2 (April 1951),passim.

${ }^{24}$ Sir Brook Taylor to Castlereagh, No.24, Stuttgart, 25 October 1819, in British Envoys to Germany, Vol.I, 326.
} 
sending an emissary to Baden to try and secure the support of the grand duke. At the same time, much like his father, he expected that the House of Württemberg's opposition to Metternich's policy would oblige the House of Romanov in St. Petersburg to similarly raise an objection. ${ }^{25}$

Neither Badenese nor Russian support eventuated, and the sum total of Württemberg's objections to the decrees was that the long-suffering Wintzingerode, now foreign minister, argued in vain in a private sitting of the Diet. Even so, the brief political scuffle over the Karlsbad laws demonstrated that Metternich's objectives did not necessarily tally with those of the other leaders of Germany. It also showed that Wilhelm was not about to submit meekly to anything he viewed as an injustice forced upon the smaller states by an untrustworthy Austrian statesman. Metternich dreamed of maintaining a balance of power, but Wilhelm only saw this as a dangerous, forced stagnation, at the hands of a "wellgroomed, well-mannered Mephistopheles."26 Much later, in an unguarded conversation with one of Brook Taylor's successors as minister to Württemberg, Sir George Shee, Wilhelm expressed his exasperation with Austria's self-serving German policies, while the possibility of war with France threatened the borders of the southern states:

His Majesty went on to say that though this Country was small they were equally interested in great European questions, that its frontier was within four days march of the french [sic.] frontier and open to the first attack. 'Thanks' He said, 'to Monsr. de Metternich who has so long prevented a fortress being built to defend us. But his influence among us is gone. His policy has always been to forward the interests of Austria at the expence [sic.] of those of the rest of Germany, and he may depend upon it, that let

\footnotetext{
25 Taylor to Castlereagh, No.27, Stuttgart, 21 November 1819, in British Envoys to Germany, Vol.I, 327-328. 26 Peter Viereck, "New Views on Metternich”, 212.
} 
the events turn out as they may, our eyes are open to the mischief he has

done, and it will not be his councils that direct us. ${ }^{27}$

Wilhelm's bitterness towards Austria in general, and Metternich in particular, is understandable, yet somewhat paradoxical. It is clear that Metternich was not interested in extending Austria's direct influence further than he believed practical, while keeping the smaller German states in check; in doing so, he seems to have convinced Wilhelm, at least, that Austria was deliberately forcing the Mittelstaaten into a weakened state, which could only mean that Austria aimed to subjugate Württemberg and its neighbours. Hence, though Metternich acted so as to not stretch Austria too thinly, his actions convinced his south German counterparts that he aimed to "direct" them.

Wilhelm's ambivalent and, at times, hostile attitude towards Metternich and Austria prevailed for much of his reign; as we have seen, by 1840 he was levelling many of the same charges against Metternich that he was in 1819. Even so, and much to Wilhelm's chagrin, Württemberg relied a great deal on Vienna, for while Austria "continue[d] unpopular and [was] looked on with some degree of Suspicion"28 throughout the early decades of the nineteenth century, the Württemberg crown and parliament were also keenly aware that Austria played a vital role in the defence of the country.

For much of Württemberg's existence, it had not enjoyed the support of a regular, standing army, and when Friedrich had come to power in the last decade of the eighteenth century, the defence of Württemberg's borders was entirely the purview of Austria. ${ }^{29}$ When Wilhelm succeeded his father, the Württemberg Army could field 14,000 men. ${ }^{30}$ By 1840 , some 20,094 men were listed in active duty. ${ }^{31}$ This was by no means an insignificant force.

\footnotetext{
${ }^{27}$ George Shee to Viscount Palmerston, No.29, Stuttgart, 9 October 1840. FO 82/36.

${ }^{28}$ Edward Cromwell Disbrowe to Palmerston, No.13, Stuttgart, 24 March 1831. FO 82/25.

29 Paul Sauer, “Die Neuorganisation des württembergischen Heerwesens”, 395.

${ }^{30}$ Heinrich A. Eckert, Das deutsche Bundesheer (Munich: 1835), 16.

${ }^{31}$ Karl Pfaff, Geschichte des Militärwesens in Württemberg (Stuttgart: Schweizenbart, 1842), 135.
} 
Yet it must be remembered that any enemy Württemberg might face would be quite significantly numerically superior. Four years after the French defeat at Waterloo, the Württemberg military attache to Paris had reported that the French army had some 149,012 officers and men at its disposal. ${ }^{32}$ By 1840 , in the same period of time that the Württembergisches Heer had increased in size from 14,000 to 20,000, the French army had also expanded. After his October 1840 meeting with the king, Sir George Shee reported that the Heer, which had recently conducted manoeuvres, had been so impressive that the French observers at these manoeuvres "were surprised at the excellence of [the Württemberg soldiers]." Yet those same French observers belonged to an army some twenty-five times larger. "It was a dangerous thing", Wilhelm reportedly lamented to Shee, that the French had "500,000 Men on foot, and that the caprice of a Minister or the slightest shew $[$ sic. $]$ of popular feeling might convert what was meant only for defence into an engine of Attack."33

Wilhelm, his ministers, and the representatives of the Württemberg Landtag, were keenly aware of the ever-present danger that the French posed. In 1819 the Paris consulate's comprehensive surveys of the state of French military recovery had demonstrated Stuttgart's interest in the strength and resolve of an army that might very possibly desire revenge for Württemberg's defection in $1813 .{ }^{34}$ Throughout the first half of the nineteenth century, the French threat was arguably the defining foreign policy issue facing south

\footnotetext{
32 Württemberg Consulate in Paris to King Wilhelm I. von Württemberg, État complet de l'infanterie de la ligue française/Organisation de l'artillerie du la Garde Royale, No.2, 23 February 1819. HStAS.E70a Bü.537.

33 Shee to Palmerston, No.29, Stuttgart, 9 October 1840. FO 82/36.

34 These surveys were ordered by the Württemberg government via telegram to the Württemberg Consulate in Paris on 4 June 1818. Württemberg Consulate in Paris to King Wilhelm I. von Württemberg, No.2, 23 February 1819. See also, Le Moniteur Universel, No.5a, 21 February 1819; Württemberg Consulate in Paris to King Wilhelm I. von Württemberg, Le Corps du génie ort compore d'un état major general, des trois regiments l'une compagnie d'ouvrier, et l'un escadrille du train du génie and Dernier Tarifpour les Réparations d'armée, 23 February 1819. HStAS.E70a Bü.537.
} 
German governments. ${ }^{35}$ At the same time, Vienna, itself locked in difficult relations with Paris, frequently urged the southern states to fall into line with Metternich's plans for European peace, in the hope that this would present a united Austro-German front against any ill-advised French impetuosity. ${ }^{36}$

Wilhelm and his regional counterparts had little choice in the matter. Briefly, during one such period of Franco-Austrian agitation in 1831, Wilhelm and the Landtag had debated allowing the French free passage through Württemberg territory, in order to attack Austria. The intention was "to declare [the kingdom] in all Cases neutral, [...] to admit the French Troops to pass through this Country to attack Austria; and to defend this measure on the Ground of their Incompetence single handed to resist the Aggression of France." 37 Wilhelm knew that Württemberg had an army far too small to resist a French invasion, but if the French went to war with Austria, the French armies would presumably have to traverse Württemberg to get to Austria. If Württemberg remained diplomatically tied to Vienna, the French manoeuvres would thus become a full-blown invasion. One way to avoid this invasion would be to permit the French to use the state as a staging-post, or at least let the French through unmolested. The idea never developed beyond a curious hypothetical, and in any case it would most likely have ended disastrously for Stuttgart. Firstly, French intentions were always a matter of concern. Of greater concern, however, was how Austria would react to such an unholy alliance. Wilhelm considered his plan an act of neutrality, but it is doubtful that the Austrians would have agreed. Aiding and abetting Austria's potential enemy could only have been seen by the Hofburg as a hostile act by a hostile power. Had the plan been adopted by Stuttgart, even though war did not eventuate,

35 Karl Christian von Berckheim to Grand Duke Leopold von Zähringen, Karlsruhe, 6 March 1831. GlaB 46/7153. See also Peter Burg, Die Deutsche Trias in Idee und Wirklichkeit: vom Alten Reich zum Deutschen Zollverein (Stuttgart: Franz Steiner Verlag, 1989), 243.

36 Prince Clemens Lothar Wenzel von Metternich to Count Kaspar Philipp von Spiegel zum Desenberg, 21 April 1831, in Gesandtschaftsberichte aus München, Abt.II: Die Berichte der österreichischen Gesandten, ed. Anton Chroust, 2.Bd. (Darmstadt: 2001), 316.

${ }^{37}$ Disbrowe to Palmerston, No.13, Stuttgart, 24 March 1831. FO 82/25. 
it is unlikely that Vienna would have turned a blind eye to Wilhelm's 'betrayal.' Fortunately for Württemberg, the king and his diplomats soon thought better of it, and tensions eventually died down.

Wilhelm believed that the Austrians filled their self-proclaimed role of protector of Germany with "insufficiency", and made no secret of this. Even so, the sheer weight of retribution it could potentially level against Württemberg would be overwhelming. ${ }^{38}$ Therefore, while France was viewed with intense suspicion by the Württemberg leadership, so too was Württemberg's powerful patron to the south.

\section{Cultural Depictions of Germany and Austria in Württemberg.}

Stuttgart had ample political reason to distrust Vienna. Similarly, the popular sentiment in Württemberg reflected ambivalence. On the one hand, Württembergers saw Austria as a powerful liberator that had saved the state from French rule. This is to an extent reflected in the population's reception of Württemberg's monarchs. King Friedrich, who owed his throne and title to France, died unlamented by his subjects. Wilhelm, who had been the visible enemy of the French, having led the army in conjunction with the Austrians against the Grand Armée, was conversely a genuinely beloved ruler. This popularity was expressed on numerous occasions. On 28 September 1841, for example, a state pageant was held in the Schloßplatz of Stuttgart, to celebrate the twenty-fifth jubilee of Wilhelm's rule. As part of the celebrations, a 'Victory Column', or Siegessäule, was unveiled in the forecourt of the Neues Schloß, celebrating Wilhelm's victories in the "wars of liberation" (Befreiungskriege) against Napoleon. The Schwäbische Kronik newspaper from the following weekend reported that the pageant attracted thousands of schoolchildren, students, professors, advocates, soldiers, militiamen, and "believers of all denominations, not differentiated, not

\footnotetext{
38 Wilhelm's belief that Austria could not fulfil its obligations to Germany were strong enough for him to unguardedly make such a comment to the British representative in Stuttgart. It is perhaps a measure either of the close relationship that Stuttgart had with London - or else the perpetually strained and difficult relationship of the same with Vienna - that Wilhelm would be so forthcoming with Shee, or his predecessor, Disbrowe. Shee to Palmerston, No.29, Stuttgart, 9 October 1840. FO 82/36.
} 
sorted by rank, but all celebrating in brotherly unity among one another." ${ }^{39}$ In total, some 200,000 people took part in the festivities to celebrate the quarter-century reign of their king, a remarkable testament to Wilhelm's popularity. ${ }^{40}$ Notably, many hundreds of the students taking part wore black velvet shirts and red caps with gold tassels, evoking the black-red-gold colours of the German nationalists. The reports in the Kronik indicate that Wilhelm was apparently flattered of the reminder of his part in a national liberation. ${ }^{41}$

Cooperation between the German states and people was a popular concept approaching the midpoint of the nineteenth century. In many ways, this was demonstrated through the invention and exploitation of a German cultural heritage. The Brothers Grimm provided an early example of this, but nationalist cultural engagement extended beyond folktales and fairy-stories. Between the late 1780 s and 1800, a separate and distinct German musical identity began to flourish in all of the German states, and even the poorest of the states launched concert hall and festival projects to rival those of the great and wealthy provinces. ${ }^{42}$ German opera and orchestral compositions provided the Germans with a common "genealogy of identity" that, through music, separated them from their neighbours. ${ }^{43}$ Yet arguably the most important contributions to nationalist cultural development were provided by the playwrights, and in particular the circle who surrounded Goethe in Weimar. Of these, the most influential was an exiled Württemberger, Friedrich Schiller.

\footnotetext{
${ }^{39}$ Schwäbische Kronik, 3 October 1841.

40 Especially given that the location of the celebrations, the capital city Stuttgart, had a population of approximately 40,000. Thus, the Festzug involved five times the population of Württemberg's most populous city.

${ }^{41}$ Schwäbische Kronik, 3 October 1841.

42 Württemberg was praised for the quality of its state orchestra, and the extent to which the development of a musical culture was encouraged and nurtured by officialdom. David Gramit, Cultivating Music: The Aspirations, Interests, and Limits of German Musical Culture, 1770-1848 (Berkeley: University of California Press, 2002), 152.

${ }^{43}$ Celia Applegate and Pamela Potter, “The Germans as the 'People of Music': Genealogy of an Identity”, in Music and German National Identity, eds. Celia Applegate and Pamela Potter (Chicago: University of Chicago Press, 2002), 1-35. Recently, Barbara Eichner has explored similar themes in her monograph, History in Mighty Sounds: Musical Constructions of German National Identity 1848-1914 (Woodbridge: Boydell Press, 2012), passim.
} 
In many ways, Schiller was the perfect template for an artistic liberal-nationalist. Schiller had been born in Marbach, on the banks of the Neckar, but lived for many years in Ludwigsburg. There, in 1773, he had gained the patronage of Duke Karl Eugen, and studied at the elite Karlsschule military academy in Stuttgart, with the aim of becoming an army doctor like his father. In the interim, though, he had written his first play, Die Räuber; as we have seen, the play — and the role of the protagonist, Karl von Moor — reflects much of Schiller's growing disenchantment with the petty politics of the hundreds of German principalities, and the inability of the Holy Roman Empire to act as a unifying German state. He achieved his goal of becoming a regimental doctor, but serving merely his home state no longer held any appeal to him. When Die Räuber premiered in Mannheim, in neighbouring Baden, Schiller absconded without leave to attend. Arrested for desertion, he managed to flee Württemberg, becoming an exile in the process. After a few years drifting from state to state, and suffering poverty and a handful of disastrous love affairs, he settled in Weimar, made the acquaintance of Goethe, and began his most productive creative phase. ${ }^{44}$

In the postwar years, Schiller became a natural choice to lead the nationalist revival through theatre. He had died in 1805 - before Germany's 'liberation' from Napoleon and thus became the doomed patriot, waxing lyrical about Germany but never able to see his hopes for Germany come to fruition. His short life embodied much of the pan-German experience: born in a province, he had eschewed a career in the army so that he could see his play, with its common German themes, staged in another state. Ultimately he came to live amongst scholars and artists from all over Germany, including the most celebrated of all, Goethe. Moreover, even though he was honoured by the French as a "freedom poet", he was consistently skeptical of the Revolution, unlike Klopstock, or his fellow Württemberger

\footnotetext{
44 Cora Lee Kluge, "Through the Biographical Lens: Schiller and the Ladies", Monatshefte 97, 3 (Fall 2005), 450-451; Andrew Cusack, "'Der schein ist gegen sie': Physiognomy and Honour in Schiller's 'Der Verbrecher aus verlorener Ehre", The Modern Language Review 101, 3 (July 2006), 759.
} 
Hölderlin, and therefore was not tainted with any suggestion of anti-German collaborationism. Indeed, the year before Klopstock praised the French for "climb[ing] the summit of Freedom" in his poem Sie und nicht wir, Schiller had written his mournful lament of the political situation in Germany, and in particular the failure of unity in the face of petty dynastic interests. "Germany? But where is it located? I cannot find the country", he complained, adding that "where the academic [Germany] begins the political [Germany] ends.”`5 Schiller's damnation of petty politics resonated with late-Revolution and early-Napoleonic Germany, when the Klein- and Mittelstaaten scrambled for Bonaparte's favour at the expense of Germany's independence. In the post-Napoleonic years, after the immediate optimism had died away, the words of the late playwright acquired a new significance: now it was the political Germany of Metternich that denied the existence of "academic Germany" - the Germany of concepts and ideas. Schiller had not lived to see the creation of the German Confederation and the attempted neutering of the political nationalist movement, but his works soon cut to the soul of the nationalist cause. Once more, Schiller had become a "freedom poet."

The importance of Schiller to the new liberal-nationalists cannot be overstated, and it was, ironically enough, the state that had exiled him that now began his posthumous revival. In 1825, Stuttgart hosted the first national Schillerfest, a festival celebrating the

\footnotetext{
45 Schiller's lament reflected the earlier pleas of his Weimar colleague, Christoph Martin Wieland, who four years earlier had warned of the dangers of the Revolution. "There are perhaps - or more accurately, there are without any doubt - Brandenburg, Saxon, Bavarian, Württemberg, Hamburg, Nürnberg, Frankfurt patriots, and so on”, he wrote. "But German patriots, who love the whole of the German Empire as their Fatherland, who love it above all else [...] Where are they? Who answers the call? What have they done? And what can we still expect from them?" Decades later, Goethe would similarly complain that no German political focal point existed, though he of course believed in a more "spiritual" identity that bound Germans together. "Paris is France, and all meaningful interests of the great Fatherland concentrate themselves in the capital", he told his friend, Peter Eckermann, in March 1830. "For us in Germany, such a thing is not possible. We have no city, or rather we don't even have a country, of which we can definitively say: here is Germany." For Schiller's views, see Friedrich Schiller, "Das deutsche Reich" (1797), in Johann Wolfgang von Goethe and Friedrich Schiller, Goethe-Schillers Xenien. Aus dem Schillerschen "Musen-Almanach für das Jahr 1797” und dem “Xenien-Manuscript”, ed. Adolf Stern (Leipzig: Philipp Reclam, 1871), 14. For Wieland's, see Christoph Martin Wieland, "Über deutschen Patriotismus. Betrachtungen, Fragen und Zweifel” (1793), in C.M. Wielands sämmtliche Werke, 31.Bd. (Leipzig: Verlag von Georg Joachim Göschen, 1840), 252. For Goethe's conversation with Eckermann, see Johann Peter Eckermann, Gespräche mit Goethe in den letzten Jahren seines Lebens, 3.Bd. (Leipzig: F.A. Brockhaus, 1885), 215.
} 
dramatist's work. Fourteen years later, on 8 May 1839, the city hosted another, which was well attended and proved extremely popular with both Württembergers and nonWürttembergers. The centrepiece of the festival was the production of Wilbelm Tell, which depicts the heroic deeds of the titular Swiss hero. Provoked by the injustices of a foreign oppressor - in this case, the Austrians, in the guise of the villainous lord Gessler - Tell unites the Swiss provinces, throws off the Austrian yoke, and forges the modern state of Switzerland.

Schiller's depiction of the Swiss cantons, finding unity in a time of dire emergency, reflected his own hopes for the divided Germany of his time. By 1839, it had lost none of its dramatic power, nor its political resonance. Writing in the Hallische Jabrbücher für deutsche Wissenschaft und Kunst, the Tübingen jurist and critic Christian Reinhold Köstlin remarked with considerable fervour on the unveiling of a statue of Schiller: "At last there was the means to create a fitting memorial for the spiritual hero, in the very city from which he had once fled as an outlawed prophet, and through this memorial the whole Nation will recognise him as their representative." ${ }^{6}$ It surely did not escape Köstlin's attention, as he wrote of the notable guests in attendance, that no important Austrians had made the journey to Stuttgart. "In this [celebration of humanity]", he wrote, "the Wirtemberg [sic.] Volk were not alone [...] Deputations from Manheim [sic.], Mainz, Weimar and other places, even from Brussels and from Scotland are represented by high and excellent men, in order to honour the poet." ${ }^{7}$ On the other hand, the Schillerfest in general - and the specific choice of Wilhelm Tell, with its anti-Austrian and pro-nationalist themes, as the main attraction of the festival - were thinly-veiled criticisms of Metternich's German policy, aided and abetted by the Württemberg government. Schiller had now taken his place as the favourite literary son of Germany, and Württemberg, by virtue of Wilhelm's

${ }^{46}$ Hallische Jabrbücher für deutsche Wissenschaft und Kunst, No.138, 10 June 1839.

${ }^{47} \mathrm{Ibid}$. 
'wilful disobedience' of the Karlsbad Decrees, had arguably become the only place within Germany liberal enough to give the "outlawed prophet" a voice, and to lend that voice to the nationalist cause.

\section{The Role of Austria in the German Nation.}

Even though German nationalists — including the king of Württemberg — viewed Austrian obstructionism with some hostility, this did not resolve itself into the hatred that often characterised German attitudes towards the French. Such attitudes were often the result of the privations of the Revolutionary and Napoleonic Wars; whether or not Metternich's postwar policies were unpopular, there was no doubt that the Austrians had been vital to the "liberation" of Germany between 1813 and 1815.48 During the Congress of Vienna, Austria earned some degree of goodwill among the German states by acting as their defender against the purported expansionism of Prussia and Russia. ${ }^{49}$ Furthermore, Austria’s importance to Germany could not be denied. It was, after all, enormous; in the 1840s, when the German Confederation contained approximately 70 million people, about 38 million of those were Austrian subjects. ${ }^{50}$ Therefore, even when Austria's relationship with Germany was strained at best, a significant number of German nationalists continued to look to Austria as the guiding light of German unification. This model of Germany was given the name Großdeutschland - "Greater Germany."

\footnotetext{
48 The hatred of the French can be found in some of the most celebrated German works of the early nineteenth century; see Chapter 1.

49 One of Prussia's demands after the war was the ceding of Saxony to Prussia, as a result of Saxony's alliance with Napoleon. While having to eventually give up part of its territory to Prussia, the Saxon crown owed its continued existence almost entirely to Austria, which interceded on its behalf. Furthermore, Austria had guaranteed the sovereignty of the Mittelstaaten as an enticement for them to enter the war against Napoleon; perhaps surprisingly, Metternich chose to view his word as his bond. One should not, though, read altruism as his motive in either case. To give Saxony to Prussia would have been strategically very threatening, and allowing the other Mittelstaaten to be absorbed by any other power than Austria would have also proven militarily untenable. An absorption or a return to the system of the Holy Roman Empire was similarly unattractive, for reasons already discussed. Lawrence J. Flockerzie, "Saxony, Austria, and the German Question after the Congress of Vienna, 1815-1816”, The International History Review 12, 4 (November 1990), 662, 667.

50 Lawrence Sondhaus, "Schwarzenberg, Austria, and the German Question, 1848-1851", The International History Review 13, 1 (February 1991), 2.
} 
It is a misconception, albeit a common one, that Großdeutschland was a single and unique concept of a "federative order", a loose Bund of the German states under the stewardship of a willing Habsburg monarchy. ${ }^{51}$ A.J.P. Taylor noted the broad appeal of this model, when he wrote of it attracting

$$
\begin{aligned}
& \text { [r]adicals who desired a Greater Germany; traditionalists who wished } \\
& \text { to see again the mythical glories of the Holy Roman Empire; the princes } \\
& \text { who feared the tyranny of the King of Prussia but who would accept the } \\
& \text { primacy of the Habsburg Emperor; the Roman Catholics of western } \\
& \text { Germany; all those who hoped for a Germany somehow united by } \\
& \text { peaceful agreement; in fact almost every body of opinion in Germany } \\
& \text { except the Prussian officer corps looked to Vienna for leadership. } 52
\end{aligned}
$$

This argument is eloquent, simple, and false. No doubt there were many German nationalists who hoped for a revival of the Holy Roman Empire, but this, quite simply, was never going to happen. Metternich had made sure of this at the Congress of Vienna, and during the subsequent development of the German Confederation. More importantly, while it is true that the bulk of German nationalists did want Austria's participation in a united Germany, it is equally true, as we have seen, that Austria was not universally viewed or trusted as the benevolent power to steer that united Germany. Metternich wanted no part of such a plan, and though some historians have attempted to distance the will of Metternich from the will of the Hofburg, the fact that Metternich survived as Austrian minister-president until the revolutions of 1848 indicates that these positions were, in fact, indistinguishable from one another. ${ }^{53}$

\footnotetext{
${ }^{51}$ Fritz Hellwag, Varnbüler und die deutsche Frage 1864-1866 (Stuttgart: Kohlhammer, 1934), 2; Anselm Doering-Manteuffel, Die Deutsche Frage und das europäische Staatensystem 1815-1871 (Munich: R. Oldenbourg Verlag, 2001), 68; Ronald J. Ross, "Heinrich Ritter von Srbik and 'Gesamtdeutsch' History”, The Review of Politics 31, 1 (January 1969), 90.

52 A.J.P. Taylor, The Course of German History, 115.

${ }^{53}$ James J. Sheehan, German History 1770-1866, 321-322.
} 
Thus, we should not be too hasty to equate the concept of Greater Germany with that of a model favoured by Austria. Such an idea was anathema to an Austrian leadership that wished merely to influence Germany rather than dominate it. Nor was Großdeutschland clearly defined. Its theoretical composition varied. It could be, for instance, a republic or kingdom, united under either a Federal Assembly (Bundesversammlung) or indeed the Habsburg crown, acting as an absolutist monarchy. In yet more cases, the term Großdeutschland referred to any form of united Germany, as opposed to the continued state of independence and autonomy of the constituent German countries. $^{54}$ The one common factor in every one of these definitions was simply that Austria would play a role in Germany, and while that role could be one of stewardship, it was equally likely to be merely a member of the resulting Germany, whatever composition that might eventually have. .5

\section{Whither Austria?}

There is a misconception among most histories of Germany that the southern German states were linked in very close bonds of friendship with the Austrian administrations. The character of these south German states, it is frequently suggested, was großdeutsch, and that character was engendered in a desire for one specific form of German unification. This interpretation simplifies the course of German unification as a competition of polar opposites. In truth, Großdeutschland was never a clear, set model of unity. Even if this

\footnotetext{
54 See, for instance, the differing opinions of the Badische Landeszeitung and the Allgemeine Zeitung; according to the Karlsruhe paper, Großdeutschland was a concrete German institution, inexorably linked to Austrian leadership. The Allgemeine, on the other hand, saw Greater Germany as meaning essentially a continuation of the loose German Confederation, with each of the states remaining independent or, at the very least, autonomous of a central authority. Austria, of course, would be a constituent of this Germany. Badische Landeszeitung, 6 May 1866, HStAS.E70f Bü.164; Allgemeine Zeitung, Nr.331, 27 November 1859, HStAS.E50/01 Bü.877.

55 It should be noted that Hoffmann von Fallersleben's Deutschlandlied, which would become the anthem of Germany, defines Germany as stretching "from the Meuse to the Memel / From the Adige to the Belt", which would include not just Austria, but a significant proportion of today's Poland and Belgium.
} 
problem of definition can be overcome, there were, especially in the case of Württemberg, significant obstacles to overcome before Austria could be accepted as the guiding light of Germany.

Württemberg's king and government were surprisingly receptive to the question of German unification, and King Wilhelm frequently sought to permit discourse on the subject. This was often at odds with the desires of the Austrian Hofburg. Under Metternich, Austria saw a united Germany as a dangerous hypothetical that could upset the balance of power in Europe, and that could undermine Austria’s position as a European great power. As a result, Metternich's increasingly reactionary policies caused dismay among Württemberg's German nationalists, who saw Austria's fettering away of its defensive obligations to federal Germany and nationwide repression of liberal presses and institutions as a blatant betrayal of Germany. Indeed, Austria's "insufficiency" in providing the smaller German states the means to defend themselves from foreign aggression prompted King Wilhelm to briefly consider allowing France, Württemberg's most dangerous historical enemy, free passage through Württemberg if the threat of war between France and Austria became reality.

Furthermore, Austria's 'questionable' ethnic composition caused difficulties for German national theorists, who baulked at the idea of integrating Magyars, Czechs and Italians into a unified German state. Regardless of these difficulties, it was clear that Austria could not be ignored, and that it had a role to play in Germany, and there was in Württemberg certainly a degree of pro-Habsburg sentiment as a result of Austria’s important position at the forefront of the national liberation from Napoleonic French forces. However, the popular and institutionalised suspicion of Austria's intentions cannot be dismissed. Ultimately, while Austria was an important consideration of the Württemberg government and its subjects, the idea of submitting to any form of Austrian leadership was unwelcome not just to the Stuttgart state institutions, which distrusted 
Metternich and his administration, but also to Vienna, which in any case was reluctant to engage in Germany at all. As a result, if Württemberg hoped for a powerful patron, it would have to look elsewhere. Its most obvious option was Berlin. 


\section{Chapter 3 \\ THE KINGDOM OF WÜRTTEMBERG AND EARLY KLEINDEUTSCHLAND}

WÜRTTEMBERG'S MISTRUST OF Austria, and of Metternich's intentions, soured Stuttgart's attitude towards Vienna throughout the first half of the nineteenth century. Its relationship with the other German great power, Prussia, was no less problematic. Prussia had also played a vital role in driving the French from German soil. Its government, which had been saved from oblivion mostly by the institutional reformers Karl August von Hardenberg, Heinrich Friedrich Karl vom und zum Stein, and Wilhelm von Humboldt, had earned itself a key position as one of the "Big Four" at the Congress of Vienna in 1814. Along with London, St. Petersburg and Vienna, Berlin would have a hand in deciding the future of Europe in general, and Germany in particular. ${ }^{1}$ That hand, as it turned out, seemed instead to be a fist; Prussia's demands at the Congress appeared to be alarmingly expansionist and aggressive. This, coupled with Prussias traditional militaristic traits, have created what many historians see as the duality of German powers in the nineteenth century. William Carr, for instance, saw a clear distinction between the German nationalism promoted by "the martial deeds of Prussia far beyond the frontiers of that kingdom", compared to the romanticised Germany that he felt was best characterised by Austrian influence and leadership. ${ }^{2}$ Prussian efforts to destabilise Napoleon's hold on the German states during the war had troubled Austria because they encouraged local insurrections that could upset any postwar balance. Indeed, while the notion has been challenged in more recent years, the majority of historical scholarship focusing on the

\footnotetext{
${ }^{1}$ Henry A. Kissinger, “The Congress of Vienna: A Reappraisal”, World Politics 8, 2, (January 1956), 268.

2 W. Carr, Schleswig-Holstein 1815-48: A Study in National Conflict (Manchester: Manchester University Press, 1963), 4-9.
} 
German sphere after the end of the Napoleonic Wars posit that the region was dominated by the question of hegemony, contested by Austria in one corner, and Prussia in another. ${ }^{3}$

Given Prussia's apparent warlike tendencies and the emphasis on expansionism, it is largely assumed that the smaller German states viewed Berlin with suspicion and hostility, and gravitated towards Austria. The latter fallacy has already been examined in the previous chapter. It is also true that Württemberg's relationship with Prussia in the first half of the nineteenth century was as difficult as its relationship with Austria, albeit for different reasons. Moreover, while there were proponents of Prussian stewardship of Germany, and some of those supporters of the so-called Kleindeutschland came from Württemberg, the concept itself is, much like that of Großdeutschland, misleading.

\section{Prussia's Position in the German Question.}

There is no greater enigma in German history than the Kingdom of Prussia. It had once been under the thumb of the Holy Roman Empire, but had shrugged off the Austrian shackles in the eighteenth century. Under its Hohenzollern dynasty, the state soon became a centre of philosophy, art, and a great many other virtues. "Even today", the Spiegel journalist and Berlin historian Klaus Wiegrefe wrote in 2008, "there are some typically Prussian qualities, in which the little state excelled: a sense of duty, service to the greater good, humility." Yet, he adds, this "retrospectively good Prussia is countered by the evil Prussia: cold-blooded, aggressive power politics full of blood and iron.” ${ }^{4}$ Sir Winston Churchill, debating the future of Germany in the British House of Commons in 1947, was less conciliatory to the "good Prussia." "The core of Germany", he argued persuasively, "is

\footnotetext{
${ }^{3}$ Heinrich Böhme, Deutschlands Weg zur Großmacht: Studien zum Verhältnis von Wirtschaft und Staat während der Reichsgründungszeit 1848-1881 (Cologne: Kiepenheuer \& Witsch, 1966), 8; Heinrich Ritter von Srbik, Deutsche Einheit: Idee und Wirklichkeit vom Heiligen Reich bis Königgrätz, 2.Bd. (Munich: 1935), 138-139.

${ }^{4}$ Klaus Wiegrefe, “Ein Staat von Blut und Eisen”, in Preußen: Die unbekannte Großmacht, 16-17.
} 
Prussia. This is the source of the recurring pestilence."5 Prussia, it was insisted, was a state that owed its very existence to its militarism. Its society was subordinate to its army, it was defined by "ferocious mechanical discipline", and its position in Europe had been guaranteed not through diplomacy, economics or culture, but through sheer force of arms. ${ }^{6}$ It is little wonder, then, that the existence of Prussia as an entity - social, political or otherwise - was ultimately outlawed by the Allied Control Commission in the aftermath of the Second World War.

Prussia has variously been described as a power synonymous with militarism, conquest and despotism. ${ }^{7}$ Certainly, its actions as a victorious member of the Big Four at Vienna made it appear so. Saxony's King Friedrich August had attempted to defect to the Coalition forces in 1813, much as Württemberg's Friedrich had done, but he had failed because Saxony, unlike Württemberg, was the focal point of French activity in Germany at this time; Leipzig, near which the spectacular Battle of Nations was fought between 16 and 19 October, was after all Saxony's second city. Saxony was consequently occupied by Prussian forces, and Prussia demanded its absorption. Similarly, the delegation of Humboldt and Hardenberg saw promise in the annexations of lands further south. Many of the southern states, such as Baden, Bavaria and Württemberg, had been expanded and aggrandised only through the patronage of Napoleon and, regardless of whether they had changed sides late in the day, they had still benefitted greatly from the French. Since Prussia had dynastic ties in the very south of Germany - the junior lines of the Hohenzollern family still ruled the tiny principalities of Hohenzollern-Sigmaringen and HohenzollernHechingen, nestled within the southern territorial zone of Württemberg - there was

\footnotetext{
5 Winston S. Churchill, The Second World War, Vol.V: Closing the Ring (London: Houghton Mifflin Harcourt, 1985), 141 .

${ }^{6}$ M.S. Anderson, War and Society in Europe of the Old Regime, 1618-1789 (Avon: Leicester University Press, 1988), 168-169.

${ }^{7}$ Christopher Clark, Iron Kingdom, xxii.
} 
certainly cause to suspect that Berlin could succeed in its annexations. ${ }^{8}$ If this expansion was Berlin's goal, then it was only partially successful; Saxony was rescued from complete annexation by Metternich (although it did lose some territory), and the other Mittelstaaten maintained their territorial integrity. Thus, the Prussia emerging from the meeting of nations in Vienna was certainly to be seen as a great power — indeed, its membership in the Big Four guaranteed that - but as an aggressively expansionistic power it had been frustrated at nearly every turn.

So says the orthodox view of the postwar Prussia. Yet much of this narrative is at odds with what we know of the driving forces behind the Prussia of 1815. Certainly, Prussia's king was no hawk. Friedrich Wilhelm III was a modest, docile man, given to fits of moroseness and introspection. ${ }^{9}$ In attitude, he was bourgeois and ordinary, and even at the height of the Napoleonic Wars, he was far more concerned with his family than with affairs of state. In one instance, the king was deeply upset when, upon briefly returning home after marching with Schwarzenberg's army against Napoleon in 1813, he discovered that the royal governess had taught his children to refer to him as "the king", or "his Majesty", rather than "Papa."10 He was quite content to allow reformers such as Stein, Gneisenau, Clausewitz, Humboldt, Scharnhorst and Hardenberg considerable leeway in their approach to reinvigorating and modernising all aspects of the Prussian state apparatus. Queen Luise, his wife, was also an influence for reform. Luise herself must have been extraordinarily impressed with the platform of the reformers, for it is reported that one of her lasts acts was

\footnotetext{
${ }^{8}$ Lawrence J. Flockerzie, "State-Building and Nation-Building in the 'Third Germany': Saxony after the Congress of Vienna”, Central European History 24, 3 (1991), 269-270; James J. Sheehan, German History 1770-1866, 396-397.

9 It is not for nothing that one biographer termed the king "the melancholic on the throne." Thomas StammKuhlmann, König in Preußens große Zeit: Friedrich Wilhelm III., der Melancholiker auf dem Thron (Berlin: Siedler, 1992), passim.

${ }^{10}$ Christopher Clark, Iron Kingdom, 315-316.
} 
to whisper Hardenberg's name to her distraught husband as a deathbed suggestion for the king to follow the guidance of the erstwhile diplomat. ${ }^{11}$

Friedrich Wilhelm was "cautious and pacific", and had insisted before the war that Prussia's position in Germany and Europe was one of neutrality - armed neutrality, to be sure, but neutrality nonetheless. ${ }^{12}$ Circumstances, of course, had changed by 1815 . Prussia had been defeated, crushed, and resurrected throughout almost two decades of war, but the king's own attitudes had changed little in that time. It is inconceivable that pleasant, mildmannered but ineffectual Friedrich Wilhelm III therefore guided his state towards the despotic subjugation of Germany but, given the preeminence of Prussian monarchical absolutism, it is equally inconceivable that such a policy would have been enacted without the king's direction.

The Prussian representatives' bellicose territorial demands in Vienna are also difficult to reconcile with the character of those representatives. Hardenberg and Stein, who had steered Prussia through turbulent times to the bargaining table at Schönbrunn Palace, did not fit into the typical mould of what we might consider Prussian expansionists. Both were Prussians only by naturalisation rather than by birth or heritage; Stein was born in Nassau to a Franconian family, while Hardenberg was a Hanoverian. Stein stood for the liberalisation of the Prussian state, and patterned his bureaucratic reforms on a sympathy for the pan-German sentiment. ${ }^{13}$ Hardenberg, on the other hand, was more steeped in the authoritarian traditions of Prussia than Stein, but neither he nor his old and venerated

\footnotetext{
11 Thomas Stamm-Kuhlmann, König in Preußens große Zeit, 318.

12 Andreas Dorpalen, “The German Struggle against Napoleon: The East German View”, The Journal of Modern History 41, 4 (December 1969), 500; Walter M. Simon, "Prince Hardenberg", The Review of Politics 18, 1 (January 1956), 92.

13 See John R. Seeley, Life and Times of Stein, or, Germany and Prussia in the Napoleonic Age, 3 Vols. (Cambridge: University Press, 1878). In spite of almost a century and a half of newer scholarship, Seeley's work remains probably the most authoritative work on Baron vom Stein's political career and ideologies.
} 
family could be characterised as fundamentally reactionary or "Prussified", though his loyalty to his adopted state cannot be questioned. ${ }^{14}$

Nevertheless, while both Hardenberg and Stein were loyal servants of the Hohenzollern state apparatus, that loyalty had in recent years been strained by Prussia's bureaucratic impotence in the face of French demands. In 1807, Stein had been foreign minister, but he had been dismissed from his post at Napoleon's insistence. The same fate befell Hardenberg in 1809; this time, Napoleon had threatened invasion if Friedrich Wilhelm III did not dismiss his minister-president. The reappearance of both into the European political arena, at the very peace conference convened after the defeat of the enemy who had forced their sacking, was poetic revenge. However, as a result of their years in the political wilderness, both approached the Congress of Vienna to some degree as outsiders, out of step with the state they nominally represented. Indeed, they had spent their years away from the Berlin halls of power focusing on the wider geopolitical picture. Because of this, both had developed ideas that appear to be more in keeping with the rhetoric of the early pan-German nationalists than the particularism of Prussian parochialists. During the wars, for example, Stein's reform party had demanded that Prussia continue to resist France, even though the army had been all but annihilated at the disastrous battles of Jena and Auerstedt. This resistance, Stein believed, would assist in the "liberation" of the rest of Germany when the French were sufficiently weakened.15 In a letter to the Hanoverian representative in London, Count Ernst zu Münster, in 1812, Stein made his position explicit. "I have but one Fatherland", he declared boldly, "which is called Germany, and I am devoted with my whole heart to it alone and to no particular part of

\footnotetext{
${ }^{14}$ From a different branch of the Hardenberg family came, for instance, the philosopher and poet Baron Georg Friedrich Philipp von Hardenberg, better known by his nom de plûme, Novalis. Novalis' reaction to Prussia was curiously schizoid; he despised the bureaucratic Prussia as the construct of automatons, but respected some aspects of its artistic depths. Hans Kohn, "Romanticism and the Rise of German Nationalism", The Review of Politics 12, 4 (October 1950), 447.
}

15 Tim Blanning, The Pursuit of Glory: Europe 1648-1815 (London: Penguin, 2008), 657-658. 
it." ${ }^{16}$ Thus, just as it is unlikely that Friedrich Wilhelm III would have behaved in an overly aggressive manner towards the other German states, it would be equally out of character for Prussia’s key diplomats to act in such a fashion.

\section{Postwar Weaknesses and the Threat of Defeat in Victory.}

As liberal or sympathetic to the pan-German movement as they were, the Prussian diplomats still had to contend with the fact that they were negotiating with a masterful political manipulator with very clear ideas about the future composition and limitations of Germany. Hardenberg was an able reformer and a capable domestic politician, but he was neither as manipulative nor as diplomatically astute as his Austrian counterpart. Moreover, while it was a victorious power, Prussia hardly approached the Viennese negotiations from a position of strength. Prussia had suffered tremendously during the war. Of approximately 290,000 men mobilised as part of the Prussian war effort, some 134,000 of them were killed. Worse for Berlin, its most recent casualties had come during the gruelling battle to defeat Napoleon during his Hundred Days of 1815.17 Indeed, while it was true that the Battle of Waterloo, which resulted in Napoleon's final defeat, had been turned in the Allies' favour by the arrival of Field Marshal Gebhard von Blücher and the 48,000 troops of his Prussian army, this force represented all that was left of the core of the army. Indeed, two days earlier, the army had numbered nearly 85,000 , but its defeat at Ligny had cost Blücher some 20,000 men dead or wounded, and nearly half again had deserted. Thus, the success of Waterloo masked a more uncomfortable truth for a kingdom whose might and power was

\footnotetext{
16 Baron Heinrich Friedrich Karl vom und zum Stein to Count Ernst Friedrich Herbert zu Münster, 1 December 1812, in John R. Seeley, Life and Times of Stein, Vol.3, 17.

17 The number of casualties suffered during the Napoleonic Wars, on any side, is open to some debate. The figure quoted here is conservative, and does not include, as Dumas cautions, "the number of men killed in the minor engagements or dead of disease." Dumas suggests that the number of casualties should perhaps be doubled or trebled, but this seems altogether excessive, as the number of Prussian casualties would therefore approach (in the case of doubling) or tremendously exceed (in the case of trebling) the total number of soldiers the Prussian Heer had under arms throughout the wars. Christopher Clark, Iron Kingdom, 379; Samuel Dumas, Losses of Life Caused by War (Oxford: Clarendon Press, 1923), 32-33.
} 
largely predicated on the strength of its army: by 1815, that army was exhausted to the brink of collapse.

Perhaps this would have been of minor concern if Prussia were surrounded by a collection of friendly states. It was not. The alliance to which Prussia belonged was an eclectic collection of strange bedfellows, thrown together due to the threat posed by a common enemy rather than any affection held for one another. Prussia's relations with Austria were troubled at the best of times. In addition, eastern territories within Prussia's sphere of influence - particularly in Poland - had been captured by Tsar Alexander I during his armies' relentless drive westward, and the tsar had no intention of relinquishing them to Friedrich Wilhelm III. Prussia had returned to the war in 1813 not out of altruism or a duty to Germany, but because it had an imperative to do so; the alliance of Russia and Austria trampling through Germany was a nightmarish threat to Hardenberg, and Friedrich Wilhelm's chief concern was that those territories occupied or even annexed by this alliance would include the Prussian heartland. Berlin therefore entered negotiations in Vienna not as a victorious and vengeful great power, but rather as a militarily exhausted state that had already compromised its eastern borders, and was as weak as the power it had defeated. Lord Castlereagh, the British foreign secretary, claimed that the stability of Europe now relied on the strength of the victors - "Prussia, Austria and Russia ought to be as great and powerful as they ever have been" - but Prussia was, in truth, now at its lowest ebb since before the days of Friedrich the Great. ${ }^{18}$

The Prussian delegates to Vienna could not be expected to permit their state to be dismembered and emasculated by its other allies. Yet they had very few bargaining chips, and very few options for compensation. They certainly could not demand swathes of France, since the reinstatement of the Bourbon dynasty was a key war aim of the Allies, and

\footnotetext{
18 Perhaps more so; presuming that the survivors of the 290,000 mobilised men of the Preußisches Heer were all alive, still in uniform and effectively provisioned after the war, that would leave approximately 156,000 men available to fight in the Prussian army. By 1819, the vanquished French could call 149,000 men to the colours.
} 
one of the provisos of the illusory "lasting peace" was that France would join the European powers in maintaining the balance of power. ${ }^{19}$ There was no recourse for Hardenberg to demand back the territories claimed by the Russians in the east. That left the German heartland.

Prussia's expansion here had already been given the tentative approval of the British government, which saw little alternative. To come to an agreement that would actually shrink Prussia's territorial possessions would tip the balance of power in favour of Austria or Russia. To cannibalise France, the Whig statesman Edmund Burke had predicted as early as 1793, would likely force a Franco-Prussian alliance against Austria.20 As the war had progressed, Russian power had grown, alarming not just the Prussians but also the British. Russian annexations in Poland, according to the Foreign Office, threatened to force a wedge "almost into the heart of Germany", installing Alexander as the arbiter of Europe and severely disrupting London's desired balance of power. ${ }^{21}$ However, it was not just an adventurous St. Petersburg, with power outweighing its fellow victors, that concerned Castlereagh. Indeed, Whitehall expected that a victorious Austria would absorb the smaller southern German states. ${ }^{22}$ In order to maintain the balance, British diplomats concluded that the expansion of Prussia into the German interior was necessary to offset Russian and Austrian acquisitions. The only way this could be achieved, the Foreign Office reasoned, was by forfeiting the sovereignty of the smaller German states; on the other hand, not only had these smaller states mostly fought for Napoleon, but they were also largely inventions of the French emperor, and thus of questionable legitimacy. Therefore, it seemed natural to

\footnotetext{
19 Golo Mann, Deutsche Geschichte des 19. und 20. Jahrbunderts (Frankfurt am Main: Büchergilde Gutenberg, 1958), 114.

20 Stephen R. Graubard, "Castlereagh and the Peace of Europe", The Journal of British Studies 3, 1 (November 1963), 84 .

${ }^{21}$ John Bew, Castlereagh. Enlightenment, War and Tyranny, 1769-1822 (London: Quereus, 2011), 377.

22 Paul W. Schroeder, “An Unnatural 'Natural Alliance': Castlereagh, Metternich, and Aberdeen in 1813”, The International History Review 10, 4 (November 1988), 525.
} 
Hardenberg and to Castlereagh alike that Prussia should annex the territories of Saxony (which had, after all, been an enemy), and that further expansion, in line with dynastic ties, should also be considered. ${ }^{23}$

What Britain had not realised was that Metternich, who was derided by his British counterparts as a "Francophile with an excessive love of negotiations and a hankering for peace at any price", did not want a return to the Holy Roman Empire, and certainly did not want to do anything that he thought might extend the reach of Austria's competence beyond its grasp. ${ }^{24}$ Instead, Metternich was content to keep Austria's borders manageable, constrained and, above all, safe. The proposed expansion of Prussia deep into the German hinterland, southwards of Dresden and perhaps even towards the junior Hohenzollern principalities, would therefore not be an enlargement of Berlin's territories to complement Vienna's, but would instead be an encroachment of a sometimes-hostile power deep within the sphere of Austrian influence. The eventual agreement, which amounted to a limited annexation of two-fifths of Saxon lands to the north, plus some small Rhenish holdings, was therefore the only diplomatically acceptable means of compensating Berlin for territories lost. Thus, the suggestion that the Prussian juggernaut had made its intentions of aggressive expansionism clear in Vienna in 1815 is false. Prussia had few designs on sovereign German territory in 1815. What it did have were justifiable claims for remuneration for territory lost during its actions in the War of Liberation. ${ }^{25}$

\footnotetext{
23 Ibid., 525.

${ }^{24}$ Ibid., 524.

25 This is not to say that all Prussians were so benevolently inclined, or saw Saxony as an end in and of itself, just compensation for lands lost. Sometime in the early 1820s, the great military theorist and Prussian officer Carl von Clausewitz recounted an event that had occurred during the Congress of Vienna, in which Metternich "received a note one day from a Prussian general, who was indignant over this politicking and the obstacles being put in the way of Prussia's expansion. He complained bitterly to Mettternich and warned him that the Prussian Army would not just let the matter drop, should someone wish to deprive the state of its richly deserved reward." Carl von Clausewitz, "Agitation", in Historical and Political Writings, eds. Peter Paret and Daniel Moran (Princeton: Princeton University Press, 1992), 368.
} 


\section{Württemberg Perceptions of Prussian Intentions.}

Even at this early stage, and largely as a result of a series of misunderstandings, the Hohenzollern throne was viewed with some unease by the Mittelstaaten and smaller states. The mitigating circumstances that compelled the Prussians to demand Saxony's occupation did little to mollify their neighbours. The reaction of the Saxon Corps, co-opted into Allied service after the 'liberation' of Saxony in 1814, and quartered in Liège, only heightened south German concerns of Prussian reprisals. When, in March 1815, the Saxon soldiers, spurred on by alarming reports of Saxony's diplomatic annihilation, mutinied against the commanders of the Liège garrison, the rebellion was quickly and ruthlessly quashed. The ringleaders of the mutiny were immediately shot by firing squads, the Saxon General Borstell was removed from his command and imprisoned and, probably the greatest indignity, the colours and flags of the Saxon Corps were publicly burned by the Prussian authorities. ${ }^{26}$ Blücher, who had moved his headquarters to Liège (according to Treitschke, out of respect for the Saxons and in an attempt to assure them of his confidence in them), was by all accounts devastated; in his subsequent letter to the Saxon King Friedrich August, he blamed the latter for the outrage, insisting that "Your Majesty has brought the profoundest disaster upon your subjects, a respected branch of the German nation." But it was not Blücher's impassioned condemnation of Friedrich August, but his threat that he would, "if it should be necessary, [...] have the entire Saxon army shot down", that would have caused the greatest consternation among the Mittelstaaten. ${ }^{27}$ Blücher's perhaps unintended message was clear enough: Saxony, and therefore perhaps all of those German states formerly aligned with France, existed purely at the pleasure of Prussia, and if Berlin so willed it, the Prussian army would not hesitate to destroy them.

\footnotetext{
${ }^{26}$ Heinrich von Treitschke, History of Germany in the 19th Century, Vol.2: The Germanic Federation (London: G. Allen \& Unwin, 1916), 164-166.

27 Field Marshal Gebhard Leberecht von Blücher, Prince of Wahlstatt, to King Friedrich August von Wettin, Liège, 6 May 1815, in Ibid., 702-703.
} 
Whatever Blücher's justification for his threat to have the Saxon soldiers shot, it sent a far more enduring message of authoritarianism than Stein and Hardenberg's moderation in Berlin, or the Prussian delegation at the Congress of Vienna, had been able to accomplish. ${ }^{28}$ Worse, the Prussian attitude towards the representatives of the Mittelstaaten, particularly Württemberg, was frosty. Stein could not stand Friedrich; "the Württemberg tyrant or sultan" was, to the Prussian reformer, an absolutist relic of an era now gone. ${ }^{29}$ Württemberg's territorial expansion, which Austria had favoured, found an opponent in the Prussian delegation. After all, the Prussians argued, why reward a former enemy? Only after significant wrangling did the Prussians accepted that Württemberg, as well as the other south German states, could consolidate the territories they had gained under Napoleon. Granting them more, however, was out of the question.

There was much at the Congress that was difficult for Prussia to swallow, and plenty to give Berlin pause. When the Russian delegation suggested to Stein that France was a natural ally of the victorious powers, he offered a blistering rebuke: why, then, he asked, had they fought France at all? Why had they occupied French soil, and why were they determining the reparations that the French would pay?30 It was for similar reasons that the Prussians rejected the expansionist plans of the Mittelstaaten. Naturally, this was not well received in Stuttgart. Friedrich returned to the capital with an undiminished desire to expand his state whatever the great powers thought, while Crown Prince Friedrich Wilhelm, just two years from taking the throne, went home disillusioned with both the Prussians, who had been so suspicious of Württemberg, and the Austrians, who had not kept their word to assist in Württemberg's growth. ${ }^{31}$

\footnotetext{
${ }^{28}$ Stein appeared at the Congress of Vienna essentially as an "independent" delegate; after being exiled, he secured the patronage of the Russian tsar, before being named as the administrator of the occupied German territories. His importance in the Prussian negotiations in Vienna, however peripheral, should not be discounted, though.

29 Paul Sauer, Der schwäbische Zar, 455.

${ }^{30}$ Heinrich von Treitschke, History of Germany in the 19th Century, Vol.2, 212.

31 Paul Sauer, Reformer auf dem Königsthron, 91.
} 
Both Prussia and Württemberg had entered the talks in Vienna with high hopes, and had left disappointed. Crucially, the two states were at odds with each other. Prussia saw Friedrich as a Bonapartist, engendering the worst of Napoleon's absolutism, while Württemberg saw Friedrich Wilhelm III as an aggressive turncoat, betraying the interests of his fellow German states and imposing his will by force, as he had with the hapless Saxons. When Friedrich died in 1817 and was replaced by his son, now titled King Wilhelm, affairs did not improve.

\section{Post-Congress Wilhelmine Relations.}

Wilhelm had been disheartened by the Congress of Vienna, and even if he had wanted to revisit relations with Prussia, there were two major obstacles. One was that Prussia, having finally recognised the depths of its exhaustion after the devastating wars, was beginning to turn its attention inwards. Although Prussia had gained comparatively little from the Congress of Vienna, there were still administrative difficulties in incorporating the new Rhenish and Saxon territories awarded them. Before the Congress, the surviving Prussian territories encapsulated some five million people; after the inclusion of northern Saxony and the areas of the Rhineland ceded through the conference, that population had increased to 10.5 million. Furthermore, while prewar Prussia had been overwhelmingly Protestant, the Prussia that emerged from the Congress of Vienna was now home to at least four million Catholics. The sweeping reforms of the Stein and Hardenberg ministries had to be consolidated, there having been little time during the war to apply many of the social or economic innovations that had been developed before 1810. Finally, the territories that had been taken by Napoleon during the campaigns up to 1806 had been so fundamentally changed at an administrative level that the sheer scale of the task of reintegrating them into 
Prussia was staggering. According to Treitschke, "never in recent history has a great power had such difficult administrative problems to solve."32

Further, Prussia’s army had been severely depleted in the war years and, since the army was central to the Prussian state, the security concerns that this engendered were of vital importance to resolve. Austria's promotion of the German Confederation seemed to offer Berlin a solution to its growing military unease. Consequently, in 1818 Prussia lobbied for the creation of a confederal army, made up of divisions from all the members of the Confederation, and with the general staff and upper echelons managed by the Prussian officer corps. This would not only blunt any possible threat to Prussia from another German state (presumably Austria), but it would also allow Prussia to use a pan-German army as a de facto substitute for the Prussian army, thus limiting the hefty expenditure that would be required to return the latter to full strength. In the event, nothing came of these plans, mostly due to the objections of the Austrians. ${ }^{33}$ Suitably frustrated, the Prussians responded by launching an ambitious but costly rearmament and reorganisation programme, beginning in $1824.3^{34}$

The other reason for disengagement came from Stuttgart. Wilhelm's reign as king started disastrously, with the advent of a terrible famine known as the Hungerzeit. No sooner had this crisis been resolved, than the king was then required to devote his attentions to the pressing matter of a new state constitution. ${ }^{35}$ Thus, until the beginning of the 1830 s - albeit with some notable (and occasionally spectacular) exceptions -

\footnotetext{
${ }^{32}$ Heinrich von Treitschke, History of Germany in the 19th Century, Vol.2, 445-446.

${ }^{33}$ Christopher Clark, Iron Kingdom, 394.

${ }^{34}$ Dennis E. Showalter, Railroads and Rifles: Soldiers, Technology and the Unification of Germany (St Petersburg: Hailer, 1975), 78-80.

${ }^{35}$ See Chapter 4.
} 
Wilhelm, his ministers, and the Landtag were preoccupied with matters of the interior, relegating relations with both Austria and Prussia to lesser importance. ${ }^{36}$

This does not, however, mean that Prussia was ignored during this time. What is notable about Württemberg's attention to Prussia, though, is that it was mostly centred on military matters. In 1821, for instance, the Foreign Ministry in Stuttgart received an exhaustive report from its correspondent in Berlin, concerning the latest Prussian army manoeuvres, and providing in exquisite detail the numbers, disposition, and formation of the infantry and cavalry involved. In many ways, this survey of the strength and capabilities of the Prussian army mirrored that of the French army, undertaken by the Württemberg military attaché in Paris around the same time. ${ }^{37}$

Württemberg also paid close attention to the reforms that were intended to modernise the Prussian arsenal. Throughout the 1820s, King Wilhelm personally followed the new arms developments in Prussia with great curiosity. Of particular interest was the so-called "needle-gun", invented by Johann Nikolaus von Dreyse. This was an entirely new weapon, a revolutionary departure from the muzzle-loading smoothbore muskets that had dominated the battlefield for centuries. Its rifled barrel allowed for greater accuracy at range, and it was loaded through the breech, which permitted the soldier to fire from a prone position, presenting a far less vulnerable target to enemy counter-attack. The needlegun was very efficient, with a prodigious rate of fire that at least doubled the effective number of bullets that could be fired in any given period of time. ${ }^{38}$

Wilhelm's interest, and that of his War Ministry, was not merely academic. Like the Prussian army, the Württembergisches Heer also required modernisation and rearmament, and the Dreyse was an option to replace the standard firepower of the infantry. Moreover,

\footnotetext{
36 Paul Sauer, Reformer auf dem Königsthron, 315.

37 Württemberg Consulate in Berlin, Disposition zur Manöver den 14. September 1821, Berlin, 14 September 1821. HStAS.E14 Bü.824.

38 Sigurd Rabe, Das Zündnadelgewehr greift ein (Leipzig: Lühe, 1938), 18.
} 
and probably more to the point, the War Ministry wished to study the efficacy of a weapon which might soon be arming a power with which Württemberg had ambivalent relations.

The situation that Württemberg found itself in with relation to Prussia in the mid-1820s was therefore not a rosy one. Diplomatic relations were virtually non-existent, since both countries were focused by necessity on domestic affairs. When Prussia did figure in official discourse, the tone was invariably one of concern. The reality of the military situation was that Prussia was in no position to act on what the Württemberg authorities presumed were aggressive intentions. Gradually, the army was rebuilt, but its rearmament was neither rapid nor effective. After the successful trial of a perfected needle-gun at the proving-grounds of Spandau in 1839, for example, the Prussian War Ministry placed an order with Dreyse's works at Sömmerda for some 60,000 rifles. This was soon increased to 300,000 . This, the ministry calculated, was the minimum number of rifles required to equip an army the size of Prussias, with enough weapons in reserve. However, the entirely new manufacturing techniques required to build the needle-gun were time-consuming and expensive, and towards the end of the following decade, the Sömmerda works could only produce 10,000 guns annually. 39

Before the order of needle-guns, the military had focused on extensive training and rebuilding its shattered infrastructure. Thus, by the estimates of Prussia's own War Ministry, between 1815 and 1839 the army was structurally in no fit shape to go to war, while its rearmament process, beginning in 1839 , was projected to take almost three decades to complete satisfactorily. Thus, even if Prussia had designs on Germany, as so many in Württemberg and the other southern states feared, Berlin would not be able to act until well into the 1860s and, while Prussia did ultimately go to war three times in this period, it would be cynical to suggest that the Danish War, the Austro-Prussian War, or the Franco-

\footnotetext{
39 Dennis E. Showalter, Railroads and Rifles, 79-80.
} 
Prussian War were the result merely of Berlin stockpiling enough rifles. ${ }^{40}$ Finally, the key focus of early nineteenth-century Prussian policy being on a return to internal normality, there were no Prussian designs on the other German states - and certainly not any plans that survived fifty years of gestation.

It is also, perhaps, taking too strong a position to claim that Württemberg was indeed fearful of Prussian intentions. Certainly, the studies of the Foreign Ministry, and the attention given to Prussia's rearmament campaign, indicate a more than passing interest in Prussia's military capabilities, but Stuttgart was neither paralysed with fear of Berlin, nor frantic in its attempts to stave off any perceived expansionist aspirations. King Wilhelm, as we have seen, never appealed to Austria for protection, and in fact was critical of Austria's continued role in the defence of Germany. That Wilhelm was disdainful and dismissive of this potential ally is telling.

Moreover, public opinion of Prussia in Württemberg was generally ambivalent. The British envoy, Edward Cromwell Disbrowe, noted with some interest that Prussia was "considered to be a purely German power", and therefore was looked upon somewhat favourably by the Swabian population, a view that would be shared by Treitschke several decades later. ${ }^{41}$ The generally positive attitude towards Prussia was not shared by Württemberg's king, though his was an attitude more of distaste than anything else. Indeed, in 1846, the British diplomat Sir Alexander Malet, who would later become the minister plenipotentiary to the German Confederation, wrote that Wilhelm "expresse[d] more dislike than fear of Prussia." ${ }^{2}$ Wilhelm apparently enjoyed a healthy and plain-spoken relationship with the various representatives of Whitehall who were assigned to Stuttgart

\footnotetext{
40 Ibid., 99; Sigurd Rabe, Das Zündnadelgewehr greift ein, 18; Friedrich Meinecke, Das Leben des Generalfeldmarchalls Hermann von Boyen, 2.Bd. (Stuttgart: J.G. Cotta, 1899), 527-528.

41 Disbrowe to Palmerston, No.13, Stuttgart, 24 March 1831. FO 82/25; Heinrich von Treitschke, History of Germany in the 19th Century, Vol.2, 445.

42 Sir Alexander Malet to Palmerston, Stuttgart, 16 October 1846. FO 82/49.
} 
during his reign, and his middling dislike for Prussia thus makes his comments to Malet, not to mention his anti-Metternich reminiscences to George Shee, all the more remarkable.

Wilhelm was also not cowed by the overwhelming menace that so many historians attribute to Prussia. In 1843, for example, Stuttgart risked a minor diplomatic crisis over the treatment of one of its citizens. A former soldier of the Württembergisches Heer by the name of Herwegh had travelled to Berlin, and somehow managed an audience with King Friedrich Wilhelm IV. Unfortunately, Herwegh's “obnoxious” republican views had caused offence to the Prussian monarch, who had ordered him deported under guard. This earned an official complaint from the Neues Schloß. After all, the Württemberg government pointed out, the state had "taken every opportunity of shewing $[s i c].[\ldots]$ respect and partiality for the King of Prussia." For a Württemberg citizen, whatever his political persuasion, to be treated in such a fashion was therefore unconscionable, a view Wilhelm was quite willing to express to his Prussian counterpart in plain language. ${ }^{43}$

Thus, for all the fear that we may have expected from Wilhelm in particular and Württemberg in general when dealing with Prussia, what is remarkable is its near-total absence. In its place, we find some measure of willingness for cooperation with the states, and a degree of mild antipathy between Stuttgart and Berlin. In general, however, both viewed one another with something more approximating apathy.

\section{First Steps: The Zollverein.}

On the face of it, then, while Württemberg's relations with Austria were problematic, its position regarding Prussia was one marked with caution but not hostility. Austria's German policy was generally a constant, guided by Metternich. Though Wilhelm, his ministers, and the public could not shake their ingrained suspicion of Austrian intentions, by and large Vienna's actions were reasonably predictable, following a set pattern of behaviour. On the

\footnotetext{
${ }^{43}$ Henry Wellesley to Earl of Aberdeen, No.3, Stuttgart, 5 January 1843. FO 82/42.
} 
other hand, Stuttgart could not get a handle on Berlin. Here was a power led by men who proclaimed liberty and reform, but who seemed to desire conquest. Prussia's treatment of Saxony and its threats to massacre the Saxon Corps in the closing stages of the Napoleonic Wars had been brutal, but after the Congress of Vienna Berlin feigned indifference to the German situation. Only rarely between 1815 and 1848 did Prussia directly meddle in the affairs of the smaller German states, and none of those occasions appeared to follow any clear, overarching German policy. Württemberg could not help but be confused by Prussia’s intentions, and the reactions of the citizenry and those in power reflected this confusion. The pendulum of popular opinion swung wildly between favour, dislike, fear, and ambivalence; the most favourable opinions often coincided with the more strained periods of Württemberg-Austrian relations, and vice-versa. ${ }^{44}$

If Württemberg citizens found it difficult to discern Prussia's German policy, that was because Prussia had no policy to speak of in the first half of the post-Napoleonic nineteenth century. As we have seen, Berlin was desperate to consolidate and recover after its Pyrrhic victory in 1815, and its occasional manipulations of Germany between 1815 and 1848 were for the most part efforts to stabilise the geopolitical climate in the region. The suggested formation of a federal army in 1818 is one example of this. Such an army would have benefitted Prussia, but it would also have tied all German states not just into treaties, but into a unified force, which might have precluded any impetuous antagonism between the smaller states, Mittelstaaten or, indeed, the two great powers themselves. Prussia, therefore, appears to have waded into German affairs only infrequently, its objective to safeguard the region's stability.

\footnotetext{
44 Sybel suggests that the difficulties between Stuttgart and Berlin began when King Wilhelm gave Prussia "abundant cause for anxiety and annoyance by his liberal notions", which may have stirred up revolutionary sentiment. Here, he refers to Wilhelm's appearance at the 1820 Confederal conference in Vienna, detailed in more depth in Chapter 4. As we have seen, the relationship between the two states was strained since at least the Congress of Vienna, though Wilhelm's political adventurism in 1820 hardly did his standing with Berlin any favours. Heinrich von Sybel, The Founding of the German Empire by William I, Vol.I (New York: Thomas Y. Crowell \& Co., 1890), 76.
} 
However, just as Württemberg did not entirely ignore Prussia, nor did Prussia entirely ignore Germany. Politically, Berlin was largely silent on the issue of unity, but economically it could not afford to be. The German Customs Union, or Zollverein, is the clearest of the unified economic initiatives. Born as a local Prussian arrangement with the tiny Principality of Schwarzburg-Sondershausen in 1819, the Zollverein promised the opportunity to rid Germany of the "fantastic insanity" of its many hundreds of customs zones and tariffs. ${ }^{45}$ Instead of local exceptions, the union would permit the universalisation of duties, thus vastly streamlining the trading process throughout Germany, and allowing a greater mobility of goods throughout the states. Such an initiative to simplify matters was long overdue. In fact, the Zollverein was not the first body of its kind. One of the few successes of Wilhelm's regionalist agitation in the 1820 s had been the formation of a southern German customs league, designed to do much the same thing on a local level. This attempt had failed by 1833 , but it provided Prussia with a precedent upon which to pattern its own project. ${ }^{46}$

The Zollverein has rightly taken on key significance in the discourse of German history. As an economic league, it had a central impact on the industrial and trade development of Germany. By abolishing internal tariffs and simplifying pan-German customs, the Zollverein made commercial enterprise between the states a far more realistic proposition. That economic development was not necessarily to the benefit of the individual states, but in taking Germany as a single, unified financial body, its impact cannot be overstated. Its political significance, however, is not as clear. W.O. Henderson's key work, The Zollverein, presents the orthodox position: the Zollverein was conceived by Prussia as a means of excluding Austria from German affairs, and of economically strong-

\footnotetext{
45 Wilhelm Roscher, Zur Gründungsgeschichte des Zollvereins (Berlin: Stilke \& van Muyden, 1870), 5. 46 See Chapter 4.
} 
arming the smaller German states into what would ultimately become a political union. ${ }^{47}$ This interpretation is largely reflective of the impressions of Metternich, who viewed the formation of the Zollverein as a conspiracy to undermine and destabilise Austria's position in Germany. Writing to the diplomat Joseph von Trauttmansdorff, Metternich described Prussia's course of customs reform as "the agitation of a faction known only too well to me." 38

If this was the intention of the union, it was not apparent to Metternich's counterparts in the other German states. Instead, the Zollverein was soon seen by many as a logical and benevolent organisation that served a wider purpose of cooperation rather than division. ${ }^{49}$ Indeed, the union enjoyed broad-based support among the smaller German governments. In the south, it gained a passionate and influential, but unexpected admirer.

Württemberg politics in the first half of the nineteenth century was dominated by the figure of Baron Karl August von Wangenheim. Wangenheim's background perhaps gave an indicator as to his later political leanings. Born in Gotha, he was the son of a general in the service of the Duchy of Saxe-Gotha-Altenburg. Schooled in Gotha, he then studied Law at Jena, in Prussia, as well as at the Friedrich-Alexanders-Universität in Erlangen, Bavaria. After completing these studies, he entered government service in the Duchy of Saxe-Coburg-Saalfeld. However, in 1806, he left the small state, moved to Stuttgart and, on the recommendation of Duchess Charlotte of Saxe-Hildburghausen, entered into the first

\footnotetext{
47 W.O. Henderson, The Zollverein, 336-337.

48 Metternich to Joseph von Trauttmansdorff, 18 March 1828, in Lawrence J. Baack, Christian Bernstorff and Prussia: Diplomacy and Reform Conservatism, 1818-1832 (New Brunswick: Rutgers University Press, 1980), 126.

49 This is also largely the argument of Hans-Werner Hahn in his history of the development of the Zollverein. In his introduction, Hahn notes that "the political process of unifying the customs [system] was, from the very beginning, never just an economic action." Instead, though the member states joined for their own, particularist reasons, "the Zollverein influenced from the start the great political questions of the time, above all the struggle for national unity and constitutional rights." As we shall see, many of the southern proponents of the Zollverein saw it in a similar light. Hans-Werner Hahn, Geschichte des Deutschen Zollverein (Göttingen: Vandenhoeck \& Ruprecht, 1984), 5 and passim.
} 
cabinet of King Friedrich of Württemberg, as the president of the Chamber of Finance. ${ }^{50}$ Wangenheim was ambitious and energetic, and from all accounts he found no difficulty in forging genuine friendships as well as political relationships with those in power. His ability can be seen in his rapid accession to the role of vice-president of the Saxe-Coburg-Saalfeld government, so soon after graduating from university. His studies and career had taken him away from the provincial hamlet of his birth, exposing him to scholastic and court life in both the north and south of Germany. The breadth of his worldview would only be expanded when, in 1811, Friedrich appointed him as the curator of the university at Tübingen, an institution that attracted students from the aristocracy and wealthy classes throughout the region.

Wangenheim soon became one of the most polarising figures of southern politics. His appointments to the Chamber of Finance, the state judiciary, the Universität Tübingen and, in 1816, to the education portfolio, confirmed his complex but central role in the Württemberg state bureaucracy. His rise to power was not without controversy, however. His tenure at Tübingen was marked by an increasing involvement with the theories and philosophies of governance, largely influenced by his association with the radical humanist philosopher Karl August von Eschenmayer, who at the time was one of Wangenheim's professors. Largely as a result of this, in 1815 Wangenheim published a treatise on the relationship between the crown and the estates; the concepts he espoused fell broadly into the same pattern as those of the various German liberals. In particular, Wangenheim advocated a return to Württemberg's constitutional traditions. This commentary was interspersed with his meditations on the role of the citizen in a modern state ("If Man is to love the state more than he loves himself — and this he must do, for this is to him a matter of culture — then he must himself help to build the state"), and the obligations of the state to its citizens ("[The state] must be recognised as a spiritual organism, in which freedom

${ }^{50}$ British Envoys to Germany, Vol.I, 348. 
wins over the necessity of excessive force.") ${ }^{51}$ However, outrage derived not from this though Wangenheim published at a time of fierce debate regarding the potential return to constitutionalism - but from his insistence that it had been Württemberg, not any of the other German states (and certainly not Prussia or Austria) that had saved Germany from the excesses of Napoleon. "History will not forget to remark on the manliness shown by Friedrich, the first king of W[ürttemberg], in those times of fear, danger, and the most oppressive despotism", Wangenheim declared provocatively. This "manliness", he insisted, had been expressed "in order to save from overall disaster so much of the nation's independence for him and his people. In this regard he stands apart from the other German princes. No Wirtemberger [sic.] obeyed the laws of France; none bled in Spain; none grovelled before French ministers, and none felt the influence of the French secret police!"52 Wangenheim's arguments seem to have pleased Friedrich, who thereafter appointed him as Württemberg's minister at the Confederal Diet. His new role seems not to have pleased many of the other members of the National Assembly, and in 1817 Brook Taylor felt compelled to report disapprovingly to Castlereagh that Wangenheim had "rendered himself so conspicuous in the last discussions with the States"; the appointment of the mercurial and somewhat unpredictable Wangenheim took the British envoy quite by surprise. 53

Events in Frankfurt and elsewhere seemed to confirm Taylor's doubts. As the Confederation developed, Wangenheim seemed to become more and more disillusioned with the whole process. Perhaps he viewed it as little more than a farcical attempt by Vienna to keep Germany in check — an astute observation if so. Regardless, he became increasingly obstructionist. In sessions of the Diet, Wangenheim habitually voted against

\footnotetext{
51 Karl August von Wangenheim, Die Idee der Staatsvefassung in ihrer Anwendung auf Wirtembergs alte Landesverfassung und den Entwurf zu deren Erneuerung (Frankfurt a.M.: Bernard Körner, 1815), vii.

52 Ibid., 4.

53 Taylor to Castlereagh, No.42, Stuttgart, 22 November 1817, in British Envoys to Germany, Vol.I, 316.
} 
measures introduced by either Austria or Prussia, with or without instructions from Stuttgart to that effect. He had opposed the Karlsbad Decrees, in accordance with Wilhelm's wishes, but had continued his opposition well beyond their adoption; in May 1822, he even managed through fierce campaigning to push through legislation demanding that the Central Investigating Commission be dissolved, essentially stripping Metternich of the confederal authority to investigate and pursue illegal nationalist organisations. ${ }^{54}$ This was the last straw for the German great powers. Not only did Austria want to limit the audience of the liberal-nationalists; Prussia's German policy rested on projects in which Berlin had the initiative. The proposed confederal army, for example, was mooted with a Prussian high command in mind. The Zollverein, which by this stage was still a fairly limited organisation, was predicated upon Prussia guiding the economic policies of Germany. The Burschenschaften, however, offered no satisfaction of Prussia's desire for order and stability; instead, the ideas of democratic liberal-nationalism largely espoused by the most prominent Burschenschaftler gave Prussia significant pause. ${ }^{55}$ Thus, when Wangenheim engineered the downfall of the commission tasked with enacting the Confederation-wide suppression of the Burschenschaften, Prussia was more than happy to support Metternich's insistence that Wangenheim be removed from the Diet. While they were not immediately successful, another opportunity came about towards the end of the same year. In December, representatives from Austria, Prussia and Russia signed the Verona

\footnotetext{
${ }^{54}$ British Envoys to Germany, Vol.I, 349.

55 This suspicion, which verged on hysteria, stemmed from the fact that Sand, Kotzebue's assassin, was a Burschenschaftler from the Prussian university city of Jena. Press reports of the time suspected that Sand was merely one of a number of plotting, would-be assassins who had infiltrated themselves into Prussian society. Various reports from British diplomats posted to Berlin suggest that this suspicion was shared by the authorities. It is also possible that Wangenheim himself suffered the suspicions of the Prussian delegation, owing to the unfortunate fact that one student arrested in Berlin in 1819, on suspicion of plotting a public outrage, was himself named Karl Heinrich von Wangenheim. While the student was of no relation to the Württemberg diplomat, the uncommon name could very well have drawn the attention of the Prussians, especially owing to Wangenheim's frequent statements in support of the Burschenschaften. For a representative insight into the Prussian state's concerns about the Burschenschaften and the threat of revolution, see the various reports by Sir George H. Rose to the Foreign Office, contained in British Envoys to Germany, Vol.I, 88-116. Rose's telegrams to Castlereagh throughout the second half of 1819 were particularly devoted to reporting Hardenberg's methods to quell potential revolution.
} 
Circular, a statement of intent that denounced European revolutionary movements and reaffirmed the powers' commitment to respond to radicals with reactionary force. ${ }^{56}$ Nominally, the Circular was directed at the political unrest threatening to destabilise Spain at the time. Nevertheless, its relevance in the context of the continuing disagreements surrounding Karlsbad and the Burschenschaften was obvious and, when Wangenheim refused to add his support to the statement, he undermined his own credibility, and that of his state, in the confederal Diet. This time, the protests emanating from Berlin and Vienna resulted in both severing their diplomatic ties with Württemberg. Worse, their complaints were joined by one from St. Petersburg, which the House of Württemberg had often relied upon as a friendly but powerful backer. Faced with the unprecedented anger of three of the most powerful European courts, King Wilhelm had little alternative but to recall his diplomat, and Wangenheim returned to Stuttgart in official disgrace in July $1823 .{ }^{57}$

Wangenheim's political career in Wilhelm's diplomatic service may have been over in 1823, but his notorious outspokenness and demonstrated opposition to power being concentrated in the hands of the Prussian and Austrian leaders made him a prominent and leading light of south German regionalism. His defence of what he saw as Württemberg's interests in the face of high-handed Austro-Prussian chauvinism, as well as his spirited opposition to anti-liberal reforms within the confederal diet, bolstered his popularity among pan-Germanists. Wangenheim's credentials were only bolstered by his early support

\footnotetext{
56 Friedrich Wilhelm Schubert, Handbuch der allgemeinen Staatskunden von Europa, 1.Bd. 3.Teil: Die Reiche Spanien und Portugal (Königsberg: Gebrüder Bornträger, 1836), 127.

57 Though Wangenheim generally followed a diplomatic line in keeping with Wilhelm's German policy, his outspoken bluntness and open animosity towards the great powers caused no small number of headaches for the government and monarch he represented. Thus, when the British minister plenipotentiary to Stuttgart, Henry Wynn, reported the dismissal of Wangenheim to the Foreign Office, he remarked that "in the present instance His Majesty [King Wilhelm] has been highly displeased at M. de Wangenheim's acting in such direct opposition to the spirit of his Instructions, to refrain from all language which could give the least subject of remark to the Ministers of the other Powers." Indeed, Wynn suggested, it was the method by which Wangenheim delivered his rebuke to Prussia and Austria - not the actual rebuke in and of itself - that caused his recall. Henry Watkin Williams Wynn to Sir George Canning, No.4, Stuttgart, 3 June 1823, in British Envoys to Germany, Vol.I, 349; Wynn to Canning, No.6, Stuttgart, 9 June 1823, in British Envoys to Germany, Vol.I, 350; Wynn to Canning, No. 11, Baden, 17 July 1823, in British Envoys to Germany, Vol.I, 351.
} 
for a Bavarian-Württemberg Customs League, which convened in October 1824 as a counterpoint to Prussia's Zollverein. ${ }^{58}$ Effectively, Wangenheim became one of the first and most high-profile proponents of the formation of a regional bloc of states that would act as a counterbalance to the German great powers of Austria and Prussia.

Wangenheim's anti-Prussian views had earned him the attention and scorn of the Prussians. "Baron von Wangenheim [...] seemed quite excellently suited" to representing the "youthful titillation of being liberal", according to the sneering reminiscences of the Prussian consular secretary in Frankfurt, Heinrich Christian Gustaf von Kombst.59 Thus, it is all the more remarkable that, as the 1820 s progressed, Wangenheim began to change his mind about Prussia. In particular, having seen the disappointing results of Bavaria and Württemberg's attempt at a customs league, he became deeply interested in the Zollverein as a tool for the formation of a German nation-state. Accordingly, by the 1830s, this intractable enemy of the Prussians now began to advocate for Württemberg seeking membership of the Prussians' flagship commerce union. ${ }^{60}$

For Wangenheim, Württemberg joining the Zollverein was not a capitulation to Prussia, or a Prussian model of a political German state, but an opportunity to close Germany to the "foreign influence" it had been open to since the Peace of Westphalia. Wangenheim did not see the Zollverein itself as a political body, but he did believe that it would encourage closer cooperation between the Mittelstaaten, and thereby help to facilitate the first steps in a unification of these states into one. "These three states [of Baden, Bavaria and Württemberg] will, alongside Darmstadt and probably also Electoral Hesse, join in a relationship with Prussia", he explained to the privy councillor, August von

\footnotetext{
${ }^{58}$ Ludwig Kirsch, Die Zoll- und Reichssteuerverwaltungen im Großherzogthum Baden (Karlsruhe: Braun, 1885), 39. Southern German attempts to create an economic bloc are discussed in greater detail in Chapter 4.

59 Heinrich Christian Gustaf von Kombst, Der deutsche Bundestag gegen Ende des Jahres 1832. Eine politische Skizze (Strasbourg: G.L. Schuler, 1836), 22.

${ }^{60}$ Peter Burg, Die Deutsche Trias in Idee und Wirklichkeit, 349.
} 
Hartmann, in 1831. "[This] will require the other German states to follow suit. Once unity for Germany has been forged in terms of tolls and customs, the unity of politics will have the power to exert itself." 61 Wangenheim expected the Zollverein to provide some form of economic unity within Germany, and he expected that all German states, including Austria, would ultimately join. When, in 1833, a member of the Stuttgart Landtag, Wilhelm Zais, put forward a motion for Württemberg to forsake membership of the Zollverein in favour of attempting to restart the abortive Bavarian-Württemberg Customs League, Wangenheim responded with typical opprobrium, though this time it was directed at someone who, nominally at least, held the same political ideology as he did. The Zollverein, Wangenheim explained, was a fait accompli, and Zais' opposition to it was completely illogical. ${ }^{62}$ To his friend August von Hartmann, a leading member of the king's Chamber of Commerce, he explained further. The Zollverein would level the economic playing field in a region that had been dogged by thousands of distinct toll and tariff zones. Then, with a degree of economic parity, German political nationalism could pursue its course - whatever that course may be.63

Wangenheim's belief in the Zollverein's universality in Germany should not, therefore, be taken as an indicator that he had shifted allegiances to a Prussian-led Germany. Instead, he saw the Zollverein in terms of economics, first and foremost. Its secondary importance was that it could act as an enabler or facilitator of the conditions that could lead to the rise of the nation. Wangenheim may have been right, had his assumption that Austria would join the Zollverein proved correct. However, since Metternich viewed the Zollverein with intense suspicion, it did not serve the purpose

\footnotetext{
${ }^{61}$ Baron Karl August von Wangenheim to Johann Georg August von Hartmann, Coburg, 23 June 1831, in Karl Viktor von Riecke, "Zur Vorgeschichte des Deutschen Zollvereins. Auszüge aus Briefen des Freiherrn K.A. v. Wangenheim”, WVLG2 (1879), 110.

62 Peter Burg, Die deutsche Trias in Idee und Wirklichkeit, 349

63 Wangenheim to Hartmann, Coburg, 30 August 1833, in Karl Viktor von Riecke, "Zur Vorgeschichte des Deutschen Zollvereins", 111.
} 
Wangenheim had expected. Instead of providing a national economic environment, the customs union merely redefined the area of contention in Germany. Between 1815 and 1833, the two main powers were Prussia and Austria, competing over the unaligned states between them. After 1833, the two main powers were still Prussia and Austria, only now the unaligned states between them could also be called members of the Zollverein.

\section{Zollverein, National Politics, and Prussia’s Place in Württemberg.}

As much as the creation of the Zollverein was a progressive move towards economic unity, its importance should not be overstated. Prussia's central role in this organisation is significant. However, it is important to note that its first customs reforms outside its own borders were trifling affairs with tiny, insignificant states, such as SchwarzburgSondershausen. The impetus to unify Germany's complicated system of tariffs only began in earnest after the southern and central states had attempted to do so, with little success. Had these attempts succeeded, the ability of the southern states to trade between one another with far fewer duty barriers would have provided them with a significant competitive trade advantage, both within Germany and in business with other nations. Given Prussia's importance as a commercial power, it stood to reason that it would also try to fashion its own mercantile league in response, yet if we can count the formation of the Zollverein as a component of Prussia's German policy, then this policy was reactive rather than proactive. Prussia saw the other German states forming their own economic blocs and responded with one of its own. At no point did Berlin set out to economically dominate the entirety of Germany on its own initiative.

Similarly, Württemberg's eventual membership of the Zollverein can be seen in a similar light. The Bavarian-Württemberg Customs League was only the last in a string of unsuccessful attempts to create a southern customs union, and most of these were spearheaded by Württemberg regionalists like Wangenheim. As Prussia's Zollverein grew, 
accepting into the fold the Hessian states among others, Württemberg's position became more difficult. Potentially, the new Prussian-led union could unite more than just a small smattering of states for customs purposes, as Bavaria and Württemberg had attempted. The economic might of Prussia, with its rapid development of modern mechanised industry, gave the Zollverein far more clout than the southern alternative, which was chaired by two largely agrarian states. The benefits of Zollverein membership soon became apparent. Wangenheim predicted that every German state would eventually join; under the circumstances, and especially after its own project had sputtered and died, Württemberg could not afford to ignore the opportunity. To do so would be crippling, as it would damage trade and severely restrict import and export potential. The Zollverein was therefore almost a form of unity by accident and happenstance rather than by design, and the incentives to member states were financial, rather than political.

Prussia was something of a mystery to Württemberg, and its role in Germany — and in Württemberg German discourse - was confused at best. On the one hand, Württembergers found it difficult to forget the near-dismemberment of Saxony in the aftermath of the Napoleonic Wars. Moreover, the Prussian government routinely followed the Austrian line in the German Confederation, further confounding liberal-nationalists who saw Metternich as a heavy-handed despot; Prussia's willingness to cooperate with Metternich soured Wangenheim's appreciation of it, and he (and others like him) began to see Prussia as another selfish actor, working against the greater good of the German people.

On the other hand, southern pan-Germanists like Wangenheim, disappointed by the abortive failures of unity projects among the Mittelstaaten - chiefly, the creation of a customs union - looked upon the Prussian initiative of the Zollverein with some optimism. This optimism did not take the form of kleindeutsch sentiment; that is, Zollverein proponents did not (necessarily) wish for Prussian hegemony over Germany. Instead, many saw the Zollverein as a template for German unification. 
In any event, the Zollverein certainly helped to soften the image of Prussia and the Hohenzollerns. The Prussian people were most often regarded positively by Württembergers as true Germans — or, at least, as more German than Austrians. Similarly, while the official relationship with the Hohenzollern dynasty was often cool, it is significant that Wilhelm did not ascribe to the Prussian kings (or, for that matter, their minister-presidents) the same hostile, Machiavellian intent of which he suspected the Austrians under Metternich. On the whole, therefore, the Kingdom of Württemberg was not entirely opposed to the Kingdom of Prussia, be it on an official political or a popular social or cultural level. However, but for some isolated instances of unbridled 'Prussophilia' on both sides, the idea of Kleindeutschland as it appears in orthodox historiography had neither gained traction in Württemberg, nor even occurred to the Prussian leadership before 1848. Acknowledging that pre-1848 Württemberg was still a state that was liberally infused with a spirit of pan-German nationalism, it is also readily apparent that neither of the accepted existing models of German unity applied to the aspirations of the Württemberg leadership or public. Perhaps, then, the concept of the German nation as a political entity was a rather more nuanced proposition than these models allowed. 


\section{CHAPTER 4 \\ INDEPENDENCE AND SOUTH GERMAN PARTICULARISM, 1815-1848}

PAN-GERMAN NATIONALIST sentiment was certainly evident in Württemberg before 1848. Württembergers welcomed Austrian troops into their liberated towns and villages during the wars against Napoleon, for instance, because of the fact that Austria had once upon a time embodied the spirit of German unity through the auspices of the Holy Roman Empire, regardless of the failings of that empire. The works of Friedrich Schiller, as we have already seen, were also passionately adopted by postwar Württembergers. The unity of the nation, embodied in works such as Wilhelm Tell, held a special significance for a society that had been engineered by Napoleon and King Friedrich. After Friedrich died and was replaced by his son, Württemberg was also in a unique position, being led by a hereditary monarch who was well disposed towards liberal reform and the spirit of pan-German nationalism. As we have seen, this often placed Württemberg at odds with its neighbours; we should recall that Wangenheim's spirited attacks on Prussia and Austria led to his recall only because of the way in which they were expressed, not because of their subject matter. With a few exceptions, Wilhelm was broadly sympathetic to German liberal-nationalists, and his opposition to the Karlsbad Decrees reflects this.

For most of the first half of the nineteenth century, however, German nationalism largely stagnated from inactivity. The foundation of a German nation-state would constitute nothing short of a revolution in terms of politics, culture and society and, like any revolution, it would require leadership and direction. Yet this is precisely what was missing: both German great powers were mired in a reactionary obsession to safeguard the status quo at all costs, while the relationships between them and the smaller German states was fractious at best. The fact that the nationalist movement existed, and was so vocal, nonetheless convinced Wilhelm that, despite the difficulties, the unification of Germany (in one form or another) would take place. But if Württemberg was not to be a member of 
a united Germany led by a great power, what then? Two further options presented themselves. One was to work in the state's own self-interest, and remain fully independent. The only other recourse available was to become a member of a smaller German amalgam: a “Third Germany", comprised of Mittelstaaten, and positioned directly in between the two “other" Germanies (Austria and Prussia), both politically and geographically.

\section{Economic Considerations and the Role of the Estates.}

Württemberg's unique political circumstances as a constitutional, parliamentary democracy of sorts were lauded by some political theorists of the age, such as the British Whig statesman Charles James Fox. Within this power-sharing arrangement between the monarchy and the Stände, however, lay the foundations of a simmering economic crisis that would ultimately create difficulties for Württemberg's autonomous financial existence. For the most part, the estates were composed of those who owned or managed farmable land and, as a mostly agrarian state, Württemberg relied heavily upon the success of the farming ventures on these lands. The economic viability of the state was therefore inexorably tied to the economic viability of the estates. This occasionally led to political tensions between the Stände and the crown, which often found themselves at odds.

The Württemberg estates, therefore, had been granted far more power over the politics of the country than in neighbouring states. Many contemporaries, such as Fox, found this laudable and progressive. ${ }^{1}$ The feeling was not always mutual; indeed, upon becoming king, one of Friedrich's first acts was to suspend the constitution and dissolve the power of the Landtag. Ostensibly, this was due to the fact that the new territories that had been absorbed as a result of Napoleon's 'gift' to his ally had never been governed by any

\footnotetext{
1 Even the harsher critics of Württemberg conceded that the theory of its dualist rule was remarkably fair. Casanova, though no fan of the duke of Württemberg, admitted that the court of Stuttgart was "the most brilliant in Europe"; Wekherlin, on the other hand, claimed that the crown was "the most philosophical" of all the German courts. Giacomo Casanova, The Memoirs of Jacques Casanova, Vol.III, 369; Wilhelm Ludwig Wekherlin, Anselmus Rabiosus Reise durch Oberdeutschland, 54.
} 
form of constitutionalism. To impose the constitution in Swabia and the old imperial cities, Friedrich claimed, would be a bureaucratic nightmare, and certainly not one to be attempted while Europe was embroiled in war. Thus, for the duration of Friedrich's kingship, the Landtag had been neutered as a political force. This would have disastrous consequences for the state after Friedrich's far more liberally-minded successor, Wilhelm, reinstated the constitution in 1819.

Until the Napoleonic Wars, the Württemberg economy was a strong and evergrowing force, with its main foci on traditional agriculture and, growing gradually in importance, textiles and clothing. The wine industry was of particular importance. Not only was it popular on the home market, but exports of Württemberg wine soon became the mainstay of the economy. Württemberg wines were particularly appreciated in the states along the Danube River, whose own vineyards were particularly poor. By contrast, the wines from the Remstal, Neckar and Voralb regions were of excellent quality, and they were also much less expensive to buy than those from the Rhine or Elsaß regions, further to the north and west. ${ }^{2}$ Moreover, Württemberg export duties from the distribution points Heidenheim for the Remstaler wines, Geislingen for the Neckar wines, and Ulm for the Voralb wines - were significantly lower than those for Rhenish wines, and states such as Bavaria were eager to trade their own commodities for the excellent Württemberg spirits. All this combined to make wine the most profitable trade for the Württemberg vintners and trading-houses. Other small industries, too, were reasonably profitable, including the farming of pigs, cabbages, cherries or snails. ${ }^{3}$

Württemberg was, therefore, a reliable and efficient agricultural state. Through the influence of Napoleon, however, Württemberg's situation soon changed. Württemberg's

\footnotetext{
${ }^{2}$ Karl Weidner, Wirtschaftspolitik in Württemberg, 12; Moriz von Rauch, "Salz- und Weinhandel zwischen Bayern und Württemberg im 18. Jahrhundert”, WVLG 33 (1927), 209.

3 Snails were mostly traded with Bavaria, which is probably accounted for by that kingdom's historically close ties with France. Karl Weidner, Wirtschaftspolitik in Württemberg, 13; David Warren Sabean, Property, Production, and Family in Neckarhausen, 1700-1870 (Cambridge: Cambridge University Press, 1990), 50.
} 
post-1806 expansion strained the existing economic structure of the state. The demands of the wars bled the country of manpower at a crucial juncture, and the kingdom fell into agrarian stagnation just as it doubled its number of mouths to feed. In other words, the economy discovered its weakness at precisely the time it could not afford to. ${ }^{4}$

In an effort to stem the deficit that had accumulated after the long years of war, the Ministry of Finance attempted to stimulate the export market. However, with the agricultural sector struggling after a decade of neglect, Württemberg suffered an unprecedented food shortage, the so-called Hungerzeit of 1816-1817.5 In the space of a year, nearly all Württembergers suffered from malnutrition. Typhus, edema and extreme hunger became killers in a state which previously had no difficulty feeding its people. In Laichingen, approximately thirty kilometres northeast of Ulm, some eighty-six percent of the population went without bread or food supplies in the month of May 1817.6 Similar shortages were experienced in all of Württemberg's major population centres, and the situation only began to improve in the latter months of 1817 .

The Hungerzeit underscored the changing financial circumstances of the state. Shortages of food supply had been exceedingly rare in Württemberg history, and the farmlands had proved efficient enough so as to maintain the state's self-sufficiency, as well as providing a surplus for export. With the much-expanded population, though, it was clear that agriculture could not necessarily support both the domestic and the export markets. As early as 1817, Wilhelm's finance minister Ferdinand Heinrich August von Weckherlin had noted the shift (particularly in Britain) from agrarian-based economics to an increasingly industrialised base, and suggested that Württemberg should focus on the development of heavy industry as a means of supplementing its income. This would then permit

\footnotetext{
${ }^{4}$ Dieter Langewiesche, Liberalismus und Demokratie, 27.

5 Walter Grube, Der Stuttgarter Landtag, 510.

${ }^{6}$ Hans Medick, "The So-Called 'Laichingen Hunger Chronicle”, History Workshop Journal 40 (Autumn 1995), 212.
} 
Württemberg to focus its arable lands on producing food necessary for the state, rather than producing it for the state and the export market. However, progress was slow, largely due to bureaucratic inertia and the reluctance of the Stände. Stuttgart, nominally both the legislative and the financial capital of Württemberg, was devoid of any industry whatsoever beyond "the underclass of small-time artisans and vintners." In comparison to Berlin, where the Oranienburg precinct was a hub of heavy industrial activity, it was not until 1859 that Stuttgart's industrial development truly began in earnest, and even then the process was gradual..$^{8}$

In part, it was the Hungerzeit, and the response to it by the government and Stände, that inexorably tied the economic circumstances of the state to its more adventurous political endeavours. Certainly, 1816 threw into sharp relief the failings of a state that had grown at a breakneck speed without having a chance to consolidate its expansion. More worryingly, the intransigence of the Stände - whether or not the Landtag was in session - demonstrated an inertia born of misguided self-interest. The representative aspect of the political process was largely in the hands of those with a vested interest in agriculture, which meant that, regardless of the attempts of men like Weckherlin to reform, modernise, and diversify the state economically, the bureaucratic inertia at a parliamentary level made such reforms difficult. Yet, even when progress was made, it was limited in scope, and not always because of the opposition of the Stände. By the middle of the century, the Württemberg government had opened seven smelting works, though the vast majority of raw metals had to be imported from the more resource-rich German states. Furthermore, the textiles export industry, centred mainly on community hand-looms, could not compete

\footnotetext{
7 At least some of Weckherlin's reforms were enacted without significant prevarication. His suggested taxation reforms, for example, were signed into law by King Wilhelm in November 1817. King Wilhelm I. von Württemberg, "I. Edikt, mehrfache Änderungen im Abgabenwesen betreffend”, Stuttgart, 18 November 1817. Königlich Württembergische Staats- und Regierungsblatt, 1817; Walter Grube, Der Stuttgarter Landtag, 511.

8 Bernhard Mann, Kleine Geschichte des Königreichs Württemberg 1806-1918 (Leinfelden-Echterdingen: DRWVerlag, 2006), 88; Otto Borst, Stuttgart: Die Geschichte der Stadt (Stuttgart: Konrad Theiss Verlag, 1973), 263-264.
} 
on any significant level with the inexpensive and mass-produced textiles from England. 9 The reason for this was not simply that the estates were too deeply entrenched in an agricultural mentality to appreciate the importance of modern industry. Indeed, one of Württemberg's most intractable problems was that, for all its good farmland and wine country, it lacked many of the raw resources used by other states to kickstart their own industrial revolutions. In an age of steam power, timber or peat remained the principal combustible materials of the state, and coal, which was virtually non-existent in any significant quantities within Württemberg, was an expensive imported commodity. Most of the early factories, in Cannstatt, Esslingen, Heidenheim and Sulz were therefore powered by waterwheels situated on adjacent rivers. ${ }^{10}$ This vastly limited the size and location of industry in the kingdom, and while the banks of the Neckar soon gave rise to more "factories" per head than in other German states, they could not compete with the industrial might of the northern German manufacturing plants, or those in France and England.

It should come as no surprise, given the reluctance of the Württemberg Landtag to consider industrial development and free enterprise laws, and the slow progress of industry in the state, that it was also slow to recognise the importance of arguably the most influential industrial development of the century: the steam locomotive. The railways became ubiquitous throughout Germany in the years between the introduction of the Adler on Germany's first railways (Nürnberg-Fürth in 1835) and the outbreak of the Franco-Prussian War in 1870. However, while Prussia, Saxony and Bavaria hastily laid track, Württemberg hesitated. It was only in 1842, after some thirteen sittings of the Landtag debating the matter, that the building of railways was approved in theory.

\footnotetext{
9 Carl Brinkmann, "The Place of Germany in the Economic History of the Nineteenth Century", The Economic History Review 4, 2 (April 1933), 131.

${ }^{10}$ In Bad Cannstatt, Esslingen and Sulz, this river is the Neckar; in Heidenheim, it is the much smaller Brenz, a tributary of the Danube. Otto Borst, Geschichte Baden-Württembergs, 275.
} 
There were, admittedly, significant reasons to exercise caution. For one, the ability to build the rails and rolling-stock did not yet exist. Still, presuming that Württemberg could build or acquire steam engines, how would they be fuelled? Coal from the Saar and the Ruhr, the best quality imported coal used in Württemberg, was marked up tremendously, costing Stuttgart 156 percent its original cost once it arrived in the kingdom. ${ }^{11}$ Württemberg, in fact, was one of only three German states without any coal deposits whatsoever; the only combustible fuel available in large consignments to the kingdom was timber, but the demands on timber were already high, driving prices upwards. ${ }^{12}$ It was for good reason, then, that some members of the Landtag opposed the building of mechanised railways, on the grounds that the timber used to heat boilers and warm carriages would cause timber prices to skyrocket even further, generating a fuel crisis. ${ }^{13}$

The objection was as much an issue of industry as it was the railways, and it would soon become apparent to even the Landtag that Württemberg's industrialisation process including the adoption of steam railways - could only be accomplished by importing coal, since timber and water power could not make up the shortfall. ${ }^{14}$ Despite the objections of some Landtag members, though, the railway, an entirely state-owned enterprise, had, by October 1845, taken its first tentative steps towards a rail network, laying a four kilometre stretch of track between Cannstatt and Untertürkheim. Ten years later, the CannstattUntertürkheim line had become part of a longer, 300 kilometre main line running between Heilbronn to Friedrichshafen via Ludwigsburg, Stuttgart, Esslingen and Ulm.

While the railways entered the public consciousness, though, confidence in the new mode of transport could not be matched by its effectiveness. The Königlich

\footnotetext{
${ }^{11}$ Ibid., 277.

12 The only two other German states without coal were the tiny Holstein-Lauenburg and Mecklenburg-Strelitz. Klaus Megerle, Württemberg im Industrialisierungsprozeß Deutschlands: Ein Beitrag zur regionalen Differenzierung der Industrialisierung (Stuttgart: Klett-Cotta, 1982), 165-166.

13 Arthur Mülberger, Die Eisenbahnreform in Württemberg (Tübingen: Laupp’schen Buchhandlung, 1896), 3.

${ }^{14}$ Klaus Megerle, Württemberg im Industrialisierungsprozeß Deutschlands, 166.
} 
Württembergischen Staats-Eisenbahnen was commonly known by its abbreviation, K.W.St.E, which was morphed into the unofficial slogan of the railway: "Komm, Weible, steig' ei!", or “Come on, woman, get on!" The Württembergers, proud of their railways, even created a folk song that remains popular in the region today: "Auf der Schwäbschen Eisebabne" ("On the Swabian Railway"). However, while the song extolled the "gschwind" (speed) of the trains, the great number of stations ("gibt's gar viele Haltstatione"), and the fact that "Babe, maid, woman and man: if you can pay and want to travel, you can” (“Bube, Mädle, Weib und Ma, kurzum alls, was zable ka”), Württemberg's rail traffic remained stunted, its network of lines halted by geography, material insufficiency, and the skepticism of the Landtag. Transported goods between Baden and Bavaria soon bypassed Württemberg altogether, a consequence of a trade agreement between Karlsruhe and Munich, and the thick Black Forest and Swabian Alps made lines through the Württemberg interior at best difficult to construct, and in some cases completely impossible. ${ }^{15}$

\section{The Rise of Württemberg Liberalism.}

Economics became something of a preoccupation for both the Württemberg state and its more radical thinkers. In part, this was because the economics of the state were inexorably tied to its survival. The expansion of the state had demonstrated its economic difficulties as an independent country, as well as the shortfalls of the political system. These difficulties encouraged the development of a reformist and broadly liberal political movement. At the heart of this movement was the king himself. At first glance, the marriage of liberalism to a hereditary monarchy seems to be an acrimonious pairing. After all, both the Hohenzollern

\footnotetext{
15 The Swabians may have enjoyed making an acronym out of the abbreviation of their railway name, but so did the neighbouring Badenese; they cheekily insisted that the letters stood for "Kein Württemberger stirbt ehrlich!" "No Württemberger dies an honest man!". Allan Mitchell, The Great Train Race: Railways and the FrancoGerman Rivalry 1815-1914 (New York: Berghahn, 2000), 46; Willi A. Boelcke, "Wege und Probleme des industriellen Wachstums im Königreich Württemberg”, ZWLG 32 (1973), 450.
} 
and Habsburg monarchies responded to liberal developments within Germany and their own states with alarm verging on panic, and the repression of liberal movements became a key priority. But circumstances in Württemberg were far different from those in Prussia or Austria. When Wilhelm inherited the throne upon Friedrich's death, he also inherited a broken political and economic system that could hardly stand the strain placed upon it. The agrarian crisis of the Hungerzeit was only the most visible example of the problems facing Württemberg. Behind the scenes, the state economy limped by. Friedrich's massive expenditure on the army and public works, not to mention the costs involved in billeting the French during their faux-occupation of the state, as well as the expenses involved in the campaigns against the French between 1813 and 1815, had led to a large public debt whose interest alone consumed close to twenty percent of the annual state budget by $1820 .{ }^{16}$ The paucity of domestic natural resources precluded the opportunity to invest in heavy industry in an attempt to generate revenue; even if such a thing were possible, the import duties on raw materials were crippling, and would negate any potential profits. At the same time, Wilhelm faced the problem that Friedrich had created, postponed, but never solved: the integration of the new, mediatised territories into the state. Friedrich's solution had been simply to ignore the problem, but the statutes of the German Confederation (specifically, Article 13) demanded that all states in the Confederation institute a new constitution. Thus, it was under the Wilhelmine crown, not the Federician, that political oversight and the rule of law would have to be extended for the first time over all Württemberg subjects, and not just those who belonged to the old ducal territories. This was hardly a straightforward procedure; in Baden, the grand duke's attempts to extend his power and

\footnotetext{
16 Gert Kollmer-von Oheimb-Loup, Innovation und Zollverein. Die Reaktion württembergischer Textilindustrieller auf den Deutschen Zollverein 1834-1874 (St. Katharinen: Scripta Mercaturae Verlag, 1996), 6-7.
} 
influence over Baden's expanded territories resulted in years of conflict verging on civil war. ${ }^{17}$

These problems - one rooted deeply within the state's particular political identity, the other engaging the wider issue of regional identity and nationality - thus presented Wilhelm with difficult prospects. Württemberg's economic problems were caused by the insularity of the Stände and the inability of the state to trade on equal terms with its neighbours. The problems facing him with regards his new constitution would be both the intractability of the Stände, which would jealously guard their power against the inclusion of the so-called New-Württembergers, and the fact that these New-Württembergers owed little or nothing to their new state, and thus had not developed a sense of Verfassungspatriotismus (constitutional patriotism) that would bind them to Wilhelm's throne. Wilhelm's answer to this was twofold, but intertwined. In the first place, the state's constitution should be as liberal as the bounds of constitutional monarchy would allow. Consequently, on 25 September 1819 he signed into law the Ludwigsburg Constitution. This document was an extraordinary set of guiding principles for a German state of the era Patterned on the old Treaty of Tübingen that had so impressed Charles James Fox, the Ludwigsburg Constitution deviated from the previous, centuries-old constitution, in that Wilhelm vigorously expanded the degree of public participation in the political process. As a result, the Ludwigsburg Constitution was more liberal than any similar document of its time. The Stände would regain their important role in the state's parliamentary system, but now that system would be expanded, and a brake would be placed on the Stände's more reactionary tendencies. The old unicameral Landtag was replaced by a bicameral assembly. The First Chamber, similar to Britain's House of Lords, comprised the leading members of the Stände, while the Second Chamber comprised twenty-three "privileged" members (nobles, the highest officials of the Lutheran and Catholic Churches, and the chancellor of

${ }^{17}$ Loyd E. Lee, "Liberal Constitutionalism as Administrative Reform", 92. 
the University of Tübingen) and seventy "People’s Representatives”, made up of seven from Stuttgart, Tübingen, Ludwigsburg, Ellwangen, Ulm, Heilbronn and Reutlingen, and another sixty-three from the remaining electoral districts. These seventy representatives were elected through direct suffrage. All male taxpayers in the kingdom carried the right to vote, a particularly permissive policy given that even the most even-handed of suffrage rights in other European countries usually only extended to property owners or members of a certain class or social milieu. ${ }^{18}$

These reforms opened the Landtag to influence from more areas of society than previously had been permitted. Where once the parliament had been dominated by landowners and agriculturalists, this was no longer guaranteed. This was especially vital when people like Weckherlin, who saw the agrarian dominance in the Landtag as a retarding factor in the state's economic development, were few and far between in the political process. Thus, while Weckherlin was attempting to introduce policies aimed at diversifying Württemberg's economic output, his king was attempting to open the parliament to those without the traditional agricultural interests.

This was a well-meaning and clever political manoeuvre by Wilhelm. But it also faced an intractable problem. Without modern industry, there were no modern industrialists to enter the Landtag and challenge the pastoralists. He therefore faced the perennial chickenand-egg problem: who would champion industry if there was no industry to champion? The only answer to this was to promote outside investment, to encourage industrialists to come to Württemberg, and thereby kickstart a homegrown industrial sector. Consequently, Wilhelm began to agitate for closer cooperation between the other states of Germany on both an economic and a political level. This, he hoped, would permit him to stabilise his

18 Paul Sauer, Baden-Württemberg: Bundesland mit parlamentarischen Traditionen (Stuttgart: Landtag des Bundeslands Baden-Württemberg, 1982), 23, 54. 
own state, secure its financial future, and provide greater security to both Württemberg and the region as a whole.

For all his energy, Wilhelm was a newly-minted king, and he lacked the diplomatic experience to deal with the other German states. Indeed, during the war years diplomacy had been left almost exclusively in the hands of his father, with dubious results. ThenCrown Prince Friedrich Wilhelm had been left to lead Württemberg's army, which he did successfully; the victory over the French at Fère Champenoise on 25 March 1814, for example, was an impressive (if not overwhelming) achievement that earned him a place at the Congress of Vienna. Once there, however, he found that negotiating with diplomats was far more difficult than leading an army. At one point, the crown prince proposed that the new German Confederation should form its own army, in order to defend the entirety of Germany from any similar threat to that which had been posed by Napoleon. ${ }^{19}$ Perhaps Friedrich Wilhelm was sincere in his motivations, but politicians rarely take anything at face value, and such was the case in Vienna. The Austrians, in particular, believed that he was manoeuvring himself for personal glory — in this case, by positioning himself as the overall commander of any confederal army that might result from an agreement at the Congress. Archduke Johann of Austria, who had led the Austrian campaigns in the Tyrol and northern Italy, recorded the reaction to Friedrich Wilhelm's perceived impertinence: "The crown prince of Württemberg, for all his talents and character, is playing an invidious role here. Ambition gnaws at him." Friedrich Wilhelm might have been brave, he acknowledged, but he could hardly be trusted when his motives were unclear. "What do courage, knowledge or talents matter", Johann grumbled, "when the character is not clear, strong or steadfast?"20

\footnotetext{
${ }^{19}$ These ideas were remarkably similar to the Prussian proposal, which also failed. See Chapter 3.

${ }^{20}$ Jean de Bourgoing, Vom Wiener Kongreß (Vienna: Herald, 1964), 372.
} 
Unsurprisingly, Friedrich Wilhelm's initiative at Vienna failed. By itself, his idea was clever and had obvious merits and benefits, but it was defeated for two reasons. Firstly, it was opposed by the vested interests of a great power (in this case, Austria). Secondly, even if the Austrians could have been persuaded to back the plan, they were deterred by what they saw as Friedrich Wilhelm's brash insolence, and his pretensions to ideas above his station. The diplomatic lesson that the prince might have learned from this failure went unheeded. So, after he ascended to the throne as King Wilhelm, he remained outspoken, unwilling to compromise, and suspicious of the great powers. Württemberg's position, both official and otherwise, reflects this liberal adventurism. The appointment of Wangenheim as Württemberg's representative at the Diet, for instance, was a provocative move, given the baron's well-known political disposition. Once there, Wangenheim actively opposed the great powers in most, if not all, of their confederal initiatives, either on the instructions of or supported by his king. In particular, Wangenheim's vocal opposition to the Karlsbad Decrees was directly as a result of Wilhelm's own opposition to them. In addition, the Ludwigsburg Constitution, liberal and inclusive as it was, caused significant concern among the reactionary courts. On the eve of the constitution's approval, Metternich expressed his worries. "The balance of the Württemberg assembly", he wrote to his emperor, "may perhaps decide the destiny of Germany."21 The Kaiser was evidently moved by Metternich's fears, writing to Wilhelm that he must be wary of the "scourge of revolution" that could be encouraged by a liberal-leaning constitution. Wilhelm responded that the constitution was not, in fact, as revolutionary as Metternich had supposed, and served mostly to show the bond between monarch and people, rather than encourage rebellion.22 Its adoption was confirmed only with the disapproval of Vienna.

\footnotetext{
21 Hartwig Brandt, Parlamentarismus in Württemberg, 1819-1870: Anatomie eines deutschen Landtags (Düsseldorf: Droste, 1987), 31.

22 Paul Sauer, Reformer auf dem Königsthron, 180-182.
} 
This is not to say that Wilhelm had turned Württemberg into a hotbed of revolutionary sentiment. On the contrary, the liberal king was still a king, and he still had his limits. In April 1822, as Wangenheim was busily making a nuisance of himself in Frankfurt, one of his colleagues from Tübingen, Friedrich List, was brought before the courts on charges of inciting rebellion against the crown. List, who had taught Public Law and Commerce at Tübingen while Wangenheim was curator there, had acquired a reputation as something of a radical. According to the British diplomat Hamilton Hamilton, "the Delinquent, Mr. List, had been long celebrated for the democratic Nature of his political tenets", and his professed ideas, which mostly focused on creating a free trade zone within Germany along the lines of what Prussia would ultimately achieve with the Zollverein, were "pregnant with Arguments of the most obnoxious Tendency." 23 List's ideas of "national economy" were hardly out of step with those of Wangenheim or of Wilhelm himself but, as in the case of Wangenheim, it was the method in which List expressed these ideas that earned him his misfortune. Having entered the Landtag as the representative for Reutlingen, List presented to the Chamber his "Reutlinger Petition", a blistering rebuke against state inefficiency and bureaucracy. In particular, List advocated a complete dissolution and reworking of the Ludwigsburg Constitution, the removal of the influence of the Stände, a radical overhaul of the taxation system, and the sale of all state-owned assets to cover the public debt. These sweeping reforms, List insisted, were necessary to stop the state bureaucracy and government from "devouring the marrow of the land, and destroying the freedom of the people."24 List's proposals, coming soon after Wilhelm had already radically reformed the political system of the state, were unreasonable and provocative, and while his complaints regarding the economic stagnation of the state were well-founded, his solutions - including, as Hamilton noted, "censur[ing], abus[ing], and vilif[ying]

\footnotetext{
${ }^{23}$ Hamilton Hamilton to Castlereagh, No.5, Stuttgart, 27 April 1822, in British Envoys to Germany, Vol.I, 335.

${ }^{24}$ Friedrich List, "Reutlinger Petition” (1821), in Friedrich Lists gesammelte Schriften, ed. Ludwig Häusser, 1.Bd. (Stuttgart and Tübingen: J.G. Cotta’sche Verlag, 1850), 75.
} 
unsparingly, every Individual employed in the Service of His Majesty" - were at best offensive, and at worst treasonous. ${ }^{25}$ The judgement against him was essentially a foregone conclusion, made more certain by List's attempt to use the trial as a means to further his political platform rather than defend himself from criminal charges. ${ }^{26}$ Upon being convicted to ten months' hard labour, List absconded - unlamented, if Hamilton's reportage is to be believed. ${ }^{27}$

The tragic example of Friedrich List demonstrates that there were limits to Wilhelm's tolerance, even when, as in this case, the political ideology was broadly in line with his own. To that end, Wilhelm had included monarchical checks and balances in the Ludwigsburg Constitution; legal boundaries permitted Wilhelm to prosecute those who criticised the government too vehemently (as in the case of List), while the king still maintained the power of veto and dissolution over the Landtag, if he felt that the representatives in the parliament were unsuitable or otherwise obstructionist. In the elections of 1831, for instance, the British envoy extraordinary to Württemberg, Edward Cromwell Disbrowe, reported with some misgivings that "the Choice [of representatives in the Landtag] is of a

\footnotetext{
${ }^{25}$ Hamilton to Castlereagh, No.5, Stuttgart, 27 April 1822, in British Envoys to Germany, Vol.I, 335.

26 Manfred Hettling, Reform obne Revolution: Bürgertum, Bürokratie und kommunale Selbstverwaltung in Württemberg von 1800 bis 1850 (Göttingen: Vandenhoeck \& Ruprecht, 1990), 103-104.

27 "Mr. List has but few friends, and, I hope \& believe not more admirers and advocates", Hamilton assured Castlereagh. In fact, List became one of the most important, albeit tragic, prophets of German national unity. $\mathrm{He}$ escaped to Strasbourg, and carried on to England, but returned to Württemberg in 1824 to face his conviction. There, he was pardoned, on condition that he emigrate to the United States. While in America, he began writing his major treatises on economics, arguing for protectionism and opposing the doctrines set out in Adam Smith's The Wealth of Nations. Catching the attention of President Andrew Jackson, in 1830 he was sent to Hamburg to become the US consul there. However, the Senate failed to ratify his appointment, which he discovered only after he arrived. Eventually, he took a diplomatic post in Leipzig, and continued to write, while at the same time lending his considerable support to the Zollverein initiative of the Prussians. Finally, in 1846, wracked by illhealth and financial disasters, he travelled to the picturesque medieval Tyrollean town of Kufstein. There, on the night of 30 November, he knelt in a ditch to the northeast of the town, pressed a pistol to his temple, and took his own life. Curiously, after his death, memorials were erected to him, both in Kufstein and in his native Reutlingen; among those who donated to the fund to build and preserve these monuments were King Ludwig of Bavaria, and King Wilhelm of Württemberg. Hamilton to Castlereagh, No.5, Stuttgart, 27 April 1822, in British Envoys to Germany, Vol.I, 335; J. Shield Nicholson, "Memoir”, in Friedrich List, The National System of Political Economy, ed. Sampson S. Lloyd (London: Longmans, Green and Co., 1909), xxxvii-xxxviii; Rolland Ray Lutz, "The German Revolutionary Student Movement, 1819-1833”, Central European History 4, 3 (September 1971), 231; Louis L. Snyder, Roots of German Nationalism (Bloomington: Indiana University Press, 1978), 7-9.
} 
very mixed Character. Three of the Proprietors of the Hoch Wächter [sic.], an ultra liberal Paper, have been chosen as well as one or two more of the same Class of unprincipled Agitators."28 Disbrowe, evidently alarmed by these elections, reported to his own prime minister that those who "find a Trafic $[$ sic. $]$ in Agitation and Ultra Liberal Doctrines more profitable [...] have been elected in very considerable numbers." In fact, the "factious demagogues" that Disbrowe feared would wrest power from the monarchy — in this case, the Hochwächter editors Tafel and Rödinger, and the author, journalist and philosopher Paul Pfizer - were, if not moderate, reasonably pliant in their roles in liberal opposition to the government. In any case, Disbrowe need not have worried, for King Wilhelm also took a dim view of the "radical-liberal opposition", and personally dissolved the Landtag in March 1833, for new elections in May. ${ }^{29}$

Disbrowe should not have been too concerned about the activities of the Hochwächter, since it was, at best, a fringe publication without a significant readership. The Staats-Anzeiger, the official paper, had far greater circulation figures, as did the semi-official Beobachter. The popular liberal press was mostly represented by the Schwäbische Merkur and its sister paper, the Schwäbischer Kronik, both generally even-handed Swabian-centric dailies. Any concerns of "Ultra Liberal Doctrines" within the pages of these newspapers would have been avoided by a perusal of the Merkur's articles. Like any liberal German paper of the era, the Merkur mildly complained of censorship and gave cautiously enthusiastic support for a national reform at the confederal level, but it also frequently

\footnotetext{
${ }^{28}$ In the same telegram, Disbrowe dismisses Wangenheim's attempted return to politics in the same year as a desperate ploy by a "wild Visionary." Disbrowe to Palmerston, No.1, Stuttgart, 8 January 1832. FO 82/26.

${ }^{29}$ It should be noted here that Wilhelm's objection to the Landtag was not that elements of it were liberal, but rather that he feared that legislative duties would grind to a halt with the complexion of the Landtag being the way it was. Furthermore, unlike many other monarchs vested with this power - a prime example being Tsar Nicholas II with regards his various Dumas between 1906 and 1913 - Wilhelm did not as a general rule dissolve the Landtag whenever it suited him. This was, he felt, an extraordinary circumstance that warranted an extraordinary reaction. Disbrowe to Palmerston, No.8, Stuttgart, 15 February 1832. FO 82/26; Hans-Ulrich Wehler, Deutsche Gesellschaftsgeschichte, 2.Bd.: Von der Reformära bis zur industriellen und politischen "Deutschen Doppelrevolution”, 1815-1845/49 (Munich: Verlag C.H. Beck, 1989), 361-362.
} 
reflected deep-seated Württemberg mistrust, in equal measures, of Prussia, Austria and France. $^{30}$ Despite the alarmist notes flourishing from Ambassador Disbrowe's pen, liberalism in Württemberg, with some notable exceptions, was characterised by its mild nature, mainstream acceptance and, certainly in the case of the views expressed in the Schwäbische Merkur, statist particularism. More to the point, the example of the 1833 dissolution of the Landtag was the exception, not the rule. By and large, Wilhelm was more than content to allow liberal discourse within his state and political system, based in no small part on the fact that he was generally sympathetic to the liberal cause. ${ }^{31}$

With some notable exceptions, Württemberg citizens remained content with the Ludwigsburg Constitution. When revolutions consumed many of the neighbouring German states in 1830, they were conspicuous in their absence in Württemberg. In 1848, when Württemberg could not escape revolution, the uprisings that occurred were comparatively mild, though they did compel Wilhelm to temporarily suspend the constitution. The worst came in 1849 , after the more rebellious elements of the National Assembly, driven from Frankfurt, found shelter in Stuttgart and agitated for revolution. Ironically, even though the 1819 constitution was no longer in effect, it was only Württemberg's principles of political freedom that allowed this Rump Parliament to reconvene there, an occurrence that would have been unthinkable in Berlin, Leipzig, Munich or Vienna. The brief but violent Stuttgart rebellion for greater freedoms, then, was only possible because Stuttgart's citizens already possessed a greater degree of freedom than

\footnotetext{
30 It should also be noted that Paul Pfizer, the author of Briefwechsel zweier Deutschen, and recipient of some of Disbrowe's mistrust, was also a correspondent for the Merkur. Otto Elben, Geschichte des Schwäbischen Merkurs, 1785-1885 (Stuttgart: Schwäbischer Merkur, 1885), 74-75, 99-103.

31 In 1850, the parliamentarian and notable liberal Robert von Mohl complained that the Ludwigsburg Constitution was "a product of its time" that precluded the people of the state from "the right to govern themselves." Mohl, however, was a liberal-nationalist of a particularly radical turn, and he would have been hardpressed to find any constitution in the world that guaranteed the type of freedoms he demanded. Robert von Mohl, "Die Geschichte der württembergischen Verfassung von 1819", Zeitschrift für die gesamte Staatswissenschaft $6,1(1850), 47,51$.
} 
their neighbours in other states. ${ }^{32}$ Whether the irony was apparent to the Rump Parliament or to King Wilhelm is uncertain. What is certain is that, in spite of this unpleasantness, Wilhelm did not shy from constitutional rule, as the constitution was reestablished in 1851. If there was a threat to Württemberg's political situation between 1815 and 1871, it did not come in the shape of revolutionary liberal elements in the interior.

\section{Third Germany in Theory: The Manuskript aus Süd-Deutschland and After.}

The second aspect of Wilhelm's plan, and one that found resonance with many of the other liberal thinkers in Württemberg, was the requirement for the state to cooperate more closely with its neighbours. This, Wilhelm had conceived as a largely economic consideration, since the importing of resources was vital to the modernisation of the state. However, Wilhelm's skepticism of the great powers, helped in no small measure by his treatment at the Congress of Vienna, and his natural reticence regarding the series of reactionary measures being introduced by Vienna and Berlin, convinced him that there was something to be gained from appealing to the nationalist cause as well. The Burschenschaften and other nationalist movements stood as eloquent demonstrations of the power and popularity of pan-German sentiment, while the populations of the southern states, in particular, grew more disillusioned, afraid, or confused by the actions of Austria and Prussia, and their unwillingness to take a stronger, leading role in German affairs. When they did act, these actions seemed to impinge upon the wellbeing of the smaller states. One example was the institution of the Karlsbad Decrees. Another had occurred during the Hungerzeit, when Wilhelm had appealed directly to the Confederation to relax export duties on vital foodstuffs, allowing Württemberg to import food and alleviate the state's famine emergency. The appeal achieved little, due in no small part to Austria and

\footnotetext{
${ }^{32}$ See Chapter 5.
} 
Prussia's reticence at backing the move. ${ }^{33}$ Württemberg thus had many precedents to assume that the great powers would pay no heed to its interests or those of its neighbours. Accordingly, almost simultaneously the Württemberg crown and south German liberalnationalists began to look at the possibility of a regional bloc of states, made up of the Mittel- and Kleinstaaten. This concept was known as 'Third Germany', to differentiate it from the two major German powers, Austria and Prussia.

There was some precedent to this sort of grouping of states. Ironically, it had been Napoleon who had provided the framework, when he had grouped his German allies into the Rheinbund in 1806. Napoleon had intended the Rheinbund to act as a collection of Mittelstaaten bound in trade, foreign policy, and defence, which would also act as a buffer zone for France against its potential eastern enemies, Prussia, Russia, and Austria. That the Bund had never consolidated into a concrete bloc was not necessarily the result of a failure of the idea, but rather due to the uncertain circumstances of the war era. Now, though, there seemed ample reason to consider a form of regional protectionism that would shield the Mittelstaaten from the selfish and unreliable great powers. ${ }^{34}$

Some form of this was, in fact, conveyed in the Confederal Acts themselves. Württemberg and Prussia had both failed to convince their peers — particularly Austria of the need for a single German army under a unified command. However, the Acts did provide for cooperation between the states on military matters. Officially, there would be a 'Confederal Army' (Bundesheer), but this was to be made up of a number of autonomous corps. These corps, in turn, were organised on regional grounds. Bavaria, as the largest of

\footnotetext{
33 Gert Kollmer-von Oheimb-Loup, Innovation und Zollverein, 6-7.

34 Württemberg was also not the first or only Mittelstaat to experiment with a regional bloc as an objective of its German policy. The Bavarian minister-president, Maximilian von Montgelas, saw closer cooperation between the southern states as a vital precondition for the success of the German Confederation, although he believed that the Confederation would be more binding than it actually was, and more in line with the form of a nation-state. This he attempted to encourage until he was dismissed in 1817. One of his most ardent supporters was the Bavarian historian, Johann Christoph von Aretin. Jörg Echternkamp, Der Aufstieg des deutschen Nationalismus (1770-1840) (Frankfurt a.M. and New York: Campus Verlag, 1998), 289.
} 
the southern military powers bar Austria, provided the manpower for VII Corps. The armies of Württemberg, Baden, Hesse-Darmstadt, Liechtenstein and the two southern Hohenzollern principalities, each being considerably smaller than the Bavarian army, were banded together to form VIII Corps, with Württemberg providing the lion's share of the manpower and materiel..$^{35}$ In theory, it was presumed that both VII and VIII Corps would act in unison, forming a larger 'southern' army of some 80,000 men that could present a united, militarised front against potential enemies.

Such a force gave the appearance of being suited to the needs of Württemberg (and, indeed, all of the constituent states), since the two corps were run not by Austrians or Prussians, but by the states that they would presumably defend in times of war. Yet the autonomy of the southern corps was deceptive; in spite of being a regional force, VII and VIII Corps still operated under the umbrella auspices of the German Confederation, which meant that they were still subject to the statutes of the Confederation, and the oversight of the other member states. In practice, this meant that VII and VIII Corps were still beholden to the Austro-Prussian guidance engineered by Metternich at the Congress of Vienna.

Seeking stronger regional cooperation, Wilhelm became more adventurous. In September 1820, a publication, the Manuskript aus Süd-Deutschland, was printed in London and distributed throughout Germany. The book was written by Friedrich Ludwig Lindner, a radical liberal who wrote under the pseudonym "George Erichson." The Manuskript itself was a provocative document, presenting approximately 300 pages of a sprawling history of the German states in recent years, as well as a plan for their future development. Lindner's line throughout the Manuskript was consistent in its praise of the Mittelstaaten at the expense of the great powers. Especially in the aftermath of the wars,

\footnotetext{
35 Ute Frevert, A Nation in Barracks: Modern Germany, Military Conscription and Civil Society (Oxford: Berg, 2004), 117.
} 
Lindner argued, the southern states (particularly Württemberg and Bavaria) had embodied the "spirit of moderation", which was threatened by the authoritarianism practiced by Vienna and Berlin. The evils of censorship and repression, he continued, had only been ameliorated by the tireless work of the Houses of Württemberg and Wittelsbach. ${ }^{36}$ In opposing Austrian and Prussian confederal initiatives, Württemberg "did more for the cause of freedom and independence of the Germans than all of the lovely words at the Congress [of Vienna] did." The southern states, he charged, were reliant on Austria for protection, but Austria's attention was firmly planted on its own security, and Vienna could not be trusted. Referring to the fortress at Ulm, which the Austrians insisted was designed for the protection of southern Germany from French invasion, Lindner noted that the geographical position of the fortress provided no protection for Württemberg or Baden, but only made sense as a "palisade for Austria, not for Germany."37 On the question of Germany, however, Lindner was particularly inflammatory. In the Diet, thirty-eight states were represented, but only thirty-six of these — that is, neither Prussia nor Austria - were "pure German states"; the two great powers, with their territories extending into Poland, Bohemia, Silesia, Galicia and Italy, contained such a mixture of ethnicities that Lindner considered them foreign powers, similar to "England, Denmark, the Netherlands and France", which also threatened to absorb Germany as their own. ${ }^{38}$ Dismissing Prussia and Austria completely, Lindner, while acknowledging the profound differences in culture, politics and traditions between the thirty-six states, declared that "we wish to raise this motley country to a position in which its fractious nature disappears before our very eyes." 39 Lindner's solution was to group the states together according to region — North Germany and South Germany - with both working together in a form of cooperative autonomy,

\footnotetext{
${ }^{36}$ Friedrich Ludwig Lindner, Manuskript aus Süd-Deutschland (London: James Griphi, 1821), 227-228.

${ }^{37}$ Ibid., 215.

38 Ibid., 234-236.

${ }^{39} \mathrm{Ibid} ., 236$.
} 
governed by their own statutory regulations and administrative systems. The end result would be to create an independent German nation-state between the two great powers, that would "relieve [Germany] of the necessity of Austrian or Prussian predominance"; the "core" of this new bloc would be Württemberg and Bavaria, since they had adopted "contemporary constitutions $[\ldots]$ as their fundamental law." 40

Lindner's Manuskript caused a sensation when it appeared. Its southern separatist leanings alarmed the Austrians in particular, who feared that the sentiments could disrupt their attempts to create a friendly (or at least neutral) buffer of states just to their north. Furthermore, while Lindner was, by himself, of little concern, the ideas he espoused were in line with those promoted by King Wilhelm. In spite of Lindner's less than auspicious political pedigree, the indignant Austrian and Prussian governments suspected that his hand had been guided by the Württemberg king.41 These suspicions were given more weight when taken in the context of Wilhelm's near-constant appeals to his Bavarian, Badenese and Hessian counterparts to consider precisely the sort of bloc that Lindner was advocating. In March 1820, at the confederal conference in Vienna, his arrival had been greeted by Wangenheim with the ambitious and ill-advised cry of "Hier fährt er hin, der König der Deutschen!" - "Here he comes, the King of the Germans!"42 This hardly impressed the Austrians (who did not wish for there to be any 'king of the Germans'), nor the Prussians (for whom a king of Germany outside of their influence would have been anathema), nor even Wilhelm's Mittelstaat counterparts, who saw his pretensions to the role as presumptuous as best, coming from a king who was nominally their equal. Suspicions were further raised when another of Lindner's publications appeared, this time under the name of Karl Heinrich Kollmanner (ostensibly a member of the privy council in

\footnotetext{
40 Ibid., 256-257.

41 British Envoys to Germany, Vol.I, 334.

42 Baron Karl Wilhelm Heinrich du Bos du Thil to Foreign Ministry (Hesse-Darmstadt), No.99, Vienna, 27 March 1820. Hes.StAD.G1/147/7.
} 
Saxony.) This time, Lindner stated that the ties that had bound Germany to Austria were those born of "spirit, friendship and fear", but that the time had come to shake off the Austrian influence. Once more, Bavaria and Württemberg were singled out as the guiding lights of Germany, the only states capable of securing the sovereignty of the Klein- and Mittelstaaten against the influences of Austria and Prussia. 43 Again, the author appealed for unity between the smaller states. The hand of Stuttgart officialdom was again suspected, and this time the Austrians responded with some venom. The Austrian politician Friedrich von Gentz, for instance, published his own rebuttal to the new pamphlet, suggesting that it came from the same mind as the earlier Manuskript, and indicating that he believed both works formed part of a wider plot to destabilise Germany for the benefit of none other than King Wilhelm of Württemberg, who fancied himself a "German Bonaparte.”44

The Lindner affairs did nothing to help Württemberg's standing with Austria, nor Prussia. Gentz and others were right to see Wilhelm as the force behind the documents; certainly, there is enough circumstantial evidence to suggest that Wilhelm had commissioned Lindner for the purpose. For a king to cooperate and act in conjunction with an infamous left-wing radical was itself an unprecedented outrage. But even if Wilhelm had not been involved in the printing of the Manuskript and the later pamphlet, the ideas espoused within them were so close to the Württemberg state policy that they only served to make the more reactionary elements in the Diet more acutely aware of the dangerous nature of that policy. Indeed, Wangenheim was so concerned that he might be implicated as the mysterious "Kollmanner", that the Württemberg Landtag was compelled to issue a statement denying his authorship of the documents in question. ${ }^{45}$ Despite the denial, the closeness of Lindner's arguments to those of Wangenheim in the Diet and the

\footnotetext{
43 Friedrich Ludwig Lindner, Ueber die gegenwärtige Lage von Europa (Frankfurt a.M. and Leipzig: Friedrich Ludwig Lindner, 1821), 17-18.

${ }_{44}$ Peter Burg, Die deutsche Trias in Idee und Wirklichkeit, 180-181.

${ }^{45}$ Ibid., 180.
} 
furore surrounding the publication of the documents were contributing factors in the worsening diplomatic relationship between Württemberg, Austria and Prussia, which eventually resulted in the latter two recalling their diplomats from Stuttgart, and demanding Wangenheim's dismissal from his role as state representative to the Confederal Diet.

In spite of the controversy surrounding the Manuskript, not to mention Wilhelm and Wangenheim's clumsy diplomatic manoeuvring, Wilhelm continued with his south German project. Initially, there were some success. Just two months after Wilhelm was prematurely called 'king of the Germans', the representatives of the governments of Bavaria, Württemberg and Baden put their names to the so-called "Viennese Declaration" (Wiener Punktation). ${ }^{46}$ This was a statement of intent to form a "commercial-political triad" within Germany, with Austria and Prussia pursuing their own systems, and the Mittelstaaten becoming an economic (and to an extent political) union. Progress on cementing this bloc, however, was slow and unwieldy. The customs conference stumbled on matters of policy, and ultimately dissolved in the middle of 1823 , fully three years after it was first convened, without coming to any significant agreement. ${ }^{47}$ It would not be until October 1824 that Württemberg and Bavaria took the first steps towards creating a true customs body, forming the Bavarian-Württemberg Customs League. A month later, in Heidelberg, HesseDarmstadt and Baden also agreed to the measure, renaming the league the South German Customs Union, or süddeutsche Zollverein. Representatives of the member states met in Stuttgart the following February, along with a deputation from Nassau, who sought membership status, to forge the fundamental laws and regulations of the new body.

\footnotetext{
46 Despite its name, the Viennese Declaration was actually ratified in Darmstadt, rather than Vienna. The discussions that led to the Darmstadt conference, however, began in late 1819 in Vienna, hence the appellation "Viennese." W.O. Henderson, The Zollverein, 58.

47 Ibid., 59-61.
} 
But these promising steps towards realising Third Germany were overtaken by other events. The members could not decide on matters of customs, and more seriously, Baden and Bavaria were by this time squabbling over territory in the Bavarian Palatinate region to the north of Baden. Baden quickly withdrew from the conference. So too did HesseDarmstadt and Nassau, leaving Bavaria and Württemberg alone to continue the process they had begun just four months earlier. ${ }^{48}$

The difficulties surrounding the customs negotiations demonstrate one of the key problems of the Third German concept. For all the common interests of the region, Third Germany was plagued by diplomatic infighting between states that may have wanted to cooperate with one another, but did not want to do so at the expense of their sovereignty. Karlsruhe's diplomatic disputes with Bavaria over Munich's territorial claims of northern Badenese lands were only the most visible manifestations of a regional disunity that undermined any chance the south German states had of forming a workable customs union. ${ }^{49}$ The Darmstadt conference, which had begun the process, was riven with disagreement and particularist politics, not just between the delegates, but within individual delegations themselves. For example, the Bavarian foreign minister, Aloys von Rechberg und Rothenlöwen, vehemently opposed the formation of any binding south German system, on the grounds that his ministry's competence in the field of foreign affairs would be limited if Bavaria's policy was tied to that of the other Mittelstaaten. Therefore, Rechberg attempted at every opportunity to undermine the work of his own finance minister, Maximilian von Lerchenfeld. This infighting amongst the delegations mired the conference in irrelevancies, such as the tedious and interminable discussions of whether escargot was to be considered a subsistence food or an export delicacy. ${ }^{50}$

\footnotetext{
${ }^{48}$ Ludwig Kirsch, Die Zoll-und Reichssteuerverwaltungen im Großherzogthum Baden, 39.

49 Loyd E. Lee, "Baden between Revolutions: State-Building and Citizenship, 1800-1848", Central European History 24, 3 (1991), 254.

${ }^{50}$ W.O. Henderson, The Zollverein, 60-61.
} 
Amidst this southern indecision and infighting, Prussia, whose own customs experiment with Schwarzburg-Sondershausen had proved a success, proposed to expand its customs union by incorporating the two Hessian states. By 1828, it had successfully amalgamated both Hesse-Kassel and Hesse-Darmstadt into the new Prussian-Hessian Customs Union, which soon attracted more states to the fold. In the south, the original signatories of the Wiener Punktation had been whittled away to just Bavaria and Württemberg, whose Bavarian-Württemberg Customs League, originally conceived as a regional economic power, began to lose traction against the more powerful Prussian-backed body. Stuttgart and Munich soon realised that a bipartite union simply lacked the economic clout necessary to make a dent in Germany. Even those who had previously supported the southern league now recognised its weaknesses, and began to desert it. Friedrich List, having returned to northern Germany, ignored his native state's initiatives in favour of those of the Prussians. The Zollverein, he wrote, would be a profound success of the liberal-nationalist movement, because it was "in the greatest degree dictated by public sentiment." 51 Wangenheim, the driving force behind the Bavarian-Württemberg Customs League, had also come to see its pitfalls. In spite of having publicly criticised HesseDarmstadt's entrance into its customs treaty with the Prussians in 1828 , he soon came to the pragmatic realisation that, with more and more states being attracted to the Prussian model, his own system was unlikely to succeed.52 Consequently, as the League faltered, Wangenheim - by now a private citizen, but still the elder statesman and most notable proponent of Württemberg Third Germanism — sought to reorientate his regionalist, liberal worldview to the new reality. His rebuke of Wilhelm Zais' attempts to drum up

\footnotetext{
51 Friedrich List, Die politisch-ökonomische Nationaleinheit der Deutschen. Aufsätze aus dem Zollvereinsblatt und andere Schriften der Spätzeit, eds. Friedrich Lenz and Erwin Wiskemann (Berlin: R. Hobbing, 1931), 167.

52 Wangenheim's correspondence with the Bavarian Third Germanist, Lerchenfeld, reveals that the Württemberger felt personally aggrieved at Darmstadt's decision. "Carthaginian loyalty and un-Carthaginian politics are the order of the day", he declared grandiosely in a telegram. Peter Burg, Die deutsche Trias in Idee und Wirklichkeit, 317-318.
} 
support for the League shows that, by 1833 , Wangenheim had given up on his regional bloc, but this was not to say that he had given up on Third Germany. Instead, as his correspondence with August von Hartmann demonstrated, Wangenheim still believed that the future of Germany still lay with "these three states", being Württemberg, Bavaria, Baden. In spite of his earlier anger at Hesse-Darmstadt, he still felt that the little state should act as a junior partner in this coalition of southern states. The Zollverein, he felt, was a means of tying the interests of these states together. It was, in essence though not design, a facilitator of southern regionalism.53 In this, his views reflected the justifications offered by the Darmstadt liberals for their support of their state's entry into the Zollverein. The HesseDarmstadt deputy Heinrich von Gagern, later to rise to the highest prominence during the 1848 revolutions and the short-lived Frankfurt Parliament, insisted in 1834 that the founding of the Zollverein had been "one of the greatest and most beneficial events to have occurred in Germany's recent history", demonstrating the "steadfast and tireless" will of the German people to become one. ${ }^{54}$ Wangenheim was not alone in believing that the Zollverein could nurture a type of national unity of which the abortive süddeutsche Zollverein had been incapable.

But Wangenheim's prediction was not entirely accurate. In some ways, the formation of the Zollverein actually impaired Württemberg's economic development, and provided little encouragement for regional engagement. Württemberg's traditional export market mainstays suffered on the imposition of the simplified tariff system. The artisan textile industry, which operated almost entirely by hand-loom, now found itself under threat from the mechanised textile plants now operating in other German states and, most notably, in Manchester; the application of the new customs duties now made it much simpler and

53 Wangenheim to Hartmann, Coburg, 23 June 1831, in Karl Viktor von Riecke, "Zur Vorgeschichte des Deutschen Zollvereins", 110; Wangenheim to Hartmann, Coburg, 30 August 1833, in Karl Viktor von Riecke, "Zur Vorgeschichte des Deutschen Zollvereins", 111.

54 Baron Heinrich von Gagern, Deutscher Liberalismus im Vormärz: Briefe und Reden, 1815-1848, eds. Paul Wentzcke and Wolfgang Klötzer (Göttingen: Musterschmidt, 1959), 137. 
more efficient for the fabric merchants from England to export directly to German consumers. The wine industry, which was already struggling after the difficult environmental conditions that had led to the Hungerzeit, now found itself competing directly with the Rhenish vintners, whose superior vintages had previously been unaffordable in Danubian states because of the convoluted system of local taxes.55 Beer, always an important aspect of German social and economic life, similarly lost headway against the centralisation of the industry in Bavaria. On all fronts, Württemberg found itself outpaced both in quality — for Rhenish wines and Bavarian beers were superior and in the quantity provided by Manchester's modern textile-manufacturing techniques. The pattern repeated itself with other industries as well. Fine bone china, for example, was crafted with magnificent detail and care at the Ludwigsburger Porzellan Manufaktur in Ludwigsburg, but porcelain was a commodity of the upper class, and Ludwigsburg faced competition from, among others, Nymphenburg, Potsdam, Frankenthal, Berlin and, most famous of all, Meissen. ${ }^{56}$ Finally, Württemberg's extremely slow rail development discouraged other states, such as Bavaria or Baden, from exporting raw materials there, since they would have to be transported via traditional, less efficient and less expedient means, thereby increasing costs and diminishing returns.

On the front of industry and goods, the Kingdom of Württemberg had, as of the 1830s, already been consigned to the status of an economic also-ran, while at the same time this development of German customs, duties and central encouragement of business opened neighbouring markets to unprecedented opportunities. Thus, the action that Wangenheim had hoped would encourage regional economic and political unity actually dissuaded it, by further undermining and weakening the financial sector of a state already lurching towards insolvency.

\footnotetext{
55 Carl Frisch, "Vortrag von Oberfinanzrat Fritz im Oberfinanzkollegium über die Selbstadministration von Weinzehnten und Weingefällen bei der Kameralverwaltung”, Stuttgart, 15 May 1820. HStAS.E221 Nr.2626.

56 C.L.K., "German Art of the Eighteenth Century”, Germanic Museum Bulletin 1, 2 (March 1936), 10.
} 


\section{Third Germany Approaching 1848.}

The initial attempts to forge southern and Mittelstaaten unity failed largely because there was no consensus as to the form this unity was to take. They were products of the fertile minds of idealists such as King Wilhelm, Wangenheim, Zais, Lindner, and in Bavaria, Lerchenfeld and to some extent Montgelas and Aretin. There was always something to retard their ambitions, however. Wilhelm had to manage his diplomatic relationships with powers that would be opposed to his plans; Wangenheim could only be effective as long as he had the support of his king; Lerchenfeld found himself undermined by the more politically powerful Rechberg. But while these attempts came to naught, this does not suggest that the entire Third German project had failed. Over the following years, regional cooperation would continue to be the most likely eventuality for some sort of united German body. In 1830, the outbreak of the July Revolution in France caused many of the German leaders to remember the events of 1789; these fears seemed to be confirmed when a number of sympathetic uprisings occurred in cities in the Rhineland, such as Cologne and Elberfeld, as well as in the Bavarian Palatinate and Baden. ${ }^{57}$ Bloody uprisings in Belgium and Russian Poland, and even the entirely peaceful but radical constitutional revolution in Switzerland, did not involve the German powers but did cause some anxiety. In particular, Austria began to mobilise, ready to invade France if revolution once again seemed likely to sweep through central Europe.

This mobilisation, however, concerned the south German states, since they believed that it might draw them into another devastating conflict, one which was not of their making or in their interests. Württemberg briefly toyed with the idea of neutrality and passive assistance to France, lest they be caught in the crossfire. Another option, proposed by the Badenese statesman Karl Christian von Berckheim, was for a "Treaty of Neutrality"

\footnotetext{
57 Jonathan Sperber, “Echoes of the French Revolution in the Rhineland, 1830-1849”, Central European History 22, 2 (June 1989), 202-203.
} 
between Bavaria, Württemberg, Hesse-Darmstadt and Baden, "in conjunction with Switzerland", which, he hoped, would dissuade both the Austrians and the French from any aggression against Baden or the other signatories. ${ }^{58}$ Berckheim's proposal was a development of an idea presented to Leopold by the Badenese consul to Stuttgart, Albert Friedrich. The consul, on the urging of King Wilhelm of Württemberg, supported a closer cooperation between Baden and Württemberg, and suggested that approaches be made to the Bavarian government, a suggestion acted upon by the Badenese leadership between March and April.59

For their part, the Bavarians were perhaps even more radical than the Württembergers and the Badenese with their proposed resistance to Austrian pressures. Shortly after the uprisings began in 1830, the Bavarian foreign minister Joseph Ludwig von Armansperg had requested a dialogue regarding the possibilities of a south German bloc, with Prussian support, to balance the powers of France and Austria. ${ }^{60}$ In Württemberg, Wilhelm also opened negotiations with his south German neighbours, arguing that an armed alliance against the Franco-Austrian threat, with or without Prussian support, would resolve the duties of the southern states to defend themselves from any internal or external threat. ${ }^{61}$ Wilhelm's plan was thwarted by the traditional foe of south German initiatives: the diplomatic squabbles of Baden and Bavaria.

Even after this failure, politicians in the southern capitals schemed to keep their states out of Austria's more adventurous affairs. Armansperg and his king, Ludwig, drafted a

\footnotetext{
58 Karl Christian von Berckheim to Grand Duke Leopold, Karlsruhe, 6 March 1831. GlaB 46/7153. See also Peter Burg, Die Deutsche Trias in Idee und Wirklichkeit, 243.

59 Albert Friedrich to Grand Duke Leopold von Zähringen, Stuttgart, 15 February 1831. GlaB 48/2748. See also Peter Burg, Die Deutsche Trias in Idee und Wirklichkeit, 244. For the reactions of the Badenese, and the counteroffer of Metternich, see Baron Friedrich Landolin Karl von Blittersdorf to the Badenese Foreign Ministry, Frankfurt, 2 April 1831. GlaB 48/1463, and Metternich to Ferdinand August Spiegel zum Desenberg, 21 April 1831, in Gesandtschaftsberichte aus München, Abt.II, 316.

${ }^{60}$ Hartmann to Holz, Stuttgart, 13 August 1830. HStAS.E75 Bü.172.

61 King Wilhelm I. von Württemberg, "Betrachtungen über die politisch-militärische Stellung von Süddeutschland”, November 1830. HStAS.E9 Bü.25.
} 
proposal to be sent to Stuttgart, suggesting that the south German representatives in the Frankfurt Diet block any Austrian attempt to mobilise the German Confederation for its own defence; at the same time, the Prussians sent a response to the southern states, cautiously supporting their plans for an autonomous bloc. However, nearly as quickly as these plans had been tentatively formulated, they were dismissed, both for their impracticality and the fact that the situation throughout Europe had changed significantly since Armansperg, Berckheim, Friedrich and Wilhelm had begun their political machinations. Württemberg, Bavaria and the other Mittelstaaten soon fell back into line behind Metternich's stewardship. ${ }^{62}$

The debacle of the south German "neutral alliance" indicated the difficulties facing the Third German project. Presumably this union would have acted as a binding military league of Mittel- and Kleinstaaten of roughly equal standing. Each state would thus continue to enjoy its own autonomy in a political sense. However, Third Germany could only project enough force as long as its presumptive founding four members Württemberg, Bavaria, Baden and Hesse-Darmstadt - were committed to it, and remained so. The withdrawal of any of these powers from the equation would have the effect of also removing a large proportion of the military strength of Third Germany. The combined strength of VII and VIII Corps of the Bundesheer was approximately 80,000 men, and were Third Germany to succeed, it would presumably have had these 80,000 men at its disposal.63 However, if Baden were to leave the coalition, this number would be reduced by at least 10,000 . If Württemberg were to leave, the strength of the army would be lowered by a quarter, and if Bavaria chose not to commit, the army would be halved. Any of these losses would have been disastrous, and yet the prospective Third German powers had

\footnotetext{
${ }^{62}$ Robert D. Billinger, Jr., "The War Scare of 1831 and Prussian-South German Plans for the End of Austrian Dominance in Germany”, Central European History 9, 3 (September 1976), 214-215.

63 Here we ignore the negligible importance of the Hohenzollern principalities, Nassau or Liechtenstein in providing military manpower.
} 
showed time and again that they could not be relied upon to commit to any long-term agreement. The Darmstadt customs conference had started promisingly, but ended in farce three years later, after the Hesse-Darmstadt representative, Karl Wilhelm Heinrich du Bos $\mathrm{du}$ Thil, lost patience with the glacial progress, and stormed out of the planning stage of the süddeutsche Zollverein. Baden had soon followed suit, owing to the animosity between Karlsruhe and Munich for control of the Bavarian Palatinate. The same issue had crippled Wilhelm's plans for a neutral south German alliance against French or Austrian influence. The only solution that existed to counter the inherent unreliability of the south German courts was for Third Germany to find itself a patron. Armansperg and Wilhelm had tapped Prussia as their potential benefactor, while Berckheim assumed that tying south German fortunes to neutral Switzerland would, in turn, guarantee the integrity of south German neutrality.

Yet these solutions invalidated the very rationale behind Third Germany. The Mittelstaaten would once more exist entirely on the favour of a foreign patron, much as they had under Napoleon in the unsatisfactory days of the Rheinbund. Furthermore, upon what patron could Third Germany rely? The approach to Prussia caused hostile alarm in Vienna, and it is not unreasonable to suggest that Austria would have attempted to impose itself between such a relationship if it had looked like it might bear fruit. The same can be said of a Third German approach to Austria (though this, of course, would have been an impossibility, given that the Third German project was a reaction against Austrian meddling). All of the Mittelstaaten had at one time or another enjoyed good relations with France, but an alliance with France would only have incurred the wrath of, at the very least, Austria. Wilhelm had recognised this in 1831, when Württemberg briefly considered passage for French troops through its territory. For the same reasons, an alliance with Russia would have been politically inconceivable, ${ }^{64}$ and Great Britain, which had done

\footnotetext{
${ }^{64}$ This, nonetheless, was an option open to a state like Württemberg, with its family ties to the Romanov family.
} 
much since the end of the Napoleonic Wars to disavow itself of most of its ties to continental Europe, would almost certainly have been neither willing nor able to provide the protection that Third Germany required.

The problem was essentially intractable. Simply put, there was no reliable or benevolent European protector to be found, and Baden and Bavaria seemed incapable of resolving their differences. In any event, the Third German project began to lose its relevance once the Zollverein stamped its financial authority on the German states, forcing Bavaria and Württemberg to bury their ambitious regional customs plans. It was not the case, as a French observer complained in 1832, that Württemberg had "the evident tendency [...] to obey without hesitation the dictates of Austria \& Prussia." 65 On the contrary, Stuttgart was active and eager to avoid the lead of Vienna and Berlin. Its plan to do so came in the form of its southern Third German bloc. Unfortunately, it simply could not find a way to make this bloc work.

The flaws of the Third German model were masked by some conspicuous but qualified successes. The süddeutsche Zollverein negotiations had shown at least some willingness on the part of the southern states to cooperate with one another, even if that cooperation never eventuated. The neutrality pact considered during the crisis years of 1830 and 1831 had misled observers into believing that the formation of a southern bloc was a realistic goal. Indeed, Third Germany now attracted a number of southern admirers who defended and perpetuated the model with an almost evangelical fervour. The publisher Philipp Jakob Siebenpfeiffer wrote blistering rebukes of "the vicissitudes of the lords in Frankfurt, following the tune of the Viennese and Berlin hurdy-gurdy." Like many of his contemporaries, Siebenpfeiffer saw the German Confederation as a sham, a means by which the great powers could "drown out the hero" of German nationalism. For

\footnotetext{
65 Wellesley to Palmerston, No.58, Stuttgart, 3 September 1834, in British Envoys to Germany, Vol.II, 370.
} 
Siebenpfeiffer, the solution to this was to unify the "constitutional states" of the south. ${ }^{66}$ Other southern publicists, such as the Hesse-Darmstadt activist Wilhelm Schulz and the Bavarian newspaper proprietor Johann Georg August Wirth, similarly saw the "true Germany" as being the "untainted" lands of the south. In order for the nationalist agenda to be furthered, they argued, Third Germany must be brought into existence. ${ }^{67}$

These zealous calls for a southern Bund were only intensified by minor diplomatic successes among the southern states, such as the formation of a Southwest German Police Union by Württemberg, Bavaria and Hesse-Darmstadt, later incorporating Baden and Nassau, in $1832 .{ }^{68}$ Developments like these were ostensibly promising, but in reality they merely diverted attention from the ponderous flaws of the Third German model. On the matter of cooperation between the key members of Third Germany in the event of war or even in the natural course of regional politics - there was no answer. Approaching the tumultuous years that began with the 1848 revolutions, then, the Third Germanists were enthused about a nationalist model for which there was no conceivable future.

In the period between the fall of Napoleon in 1815 and the fall of Metternich in 1848, Württemberg faced an existential crisis. Conceived in its modern form as a bastard state, designed to bolster Napoleon, it had encountered mixed fortunes. On a purely individual state level, the unpopular Württemberg dynasty had managed to reverse its fortunes. The despotic King Friedrich, unloved by his subjects, had given way to a son who understood and adopted principles of enlightened constitutional rule. In 1817 it would have been difficult to find a more despised German king than Friedrich, but barely a decade

\footnotetext{
${ }^{66}$ Die Bote aus Westen, 19 February 1832; Allgemeine Zeitung, 8 November 1831.

67 Wilhelm Friedrich Schulz, Deutschlands Einheit durch Nationalrepräsentation (Stuttgart: Schweizerbart, 1832), passim; Das liberale Deutschland, 3 August 1831.

68 Ironically, this union, which seemed to confirm the possibility of regionalist south German cooperation, was first mooted by Hesse-Darmstadt as a reactionary measure after the "catastrophe" of the nationalist Hambach Festival in the Rhenish Palatinate. Similarly to south Germany's efforts to create a customs union, this organisation would later form the template of a confederal police force whose seat would be Prussia. Wolfram Siemann, "Deutschlands Ruhe, Sicherheit und Ordnung": Die Anfänge der politischen Polizei 1806-1866 (Tübingen: Max Niemeyer Verlag, 1985), 87-115.
} 
later it would have been difficult to find a more admired king than Wilhelm. Through his auspices, the kingdom returned to its liberal, constitutional heritage, and Stuttgart jealously guarded its state rights in the face of what was perceived as unwarranted meddling by the German Confederation - or rather, by Vienna in the guise of the Confederation.

However, popularity does not ensure success. If trade is the lifeblood of a country's economy, Württemberg's entry into the Zollverein, necessary though it was, was ill-fated. It would not be fair to say that Württemberg's economy had been struck down fatally, but it is true that this once self-sufficient state was crippled by the hardships of war, and by rapid modernisation and centralisation with which it simply could not keep up. Militarily, too, the country could best be described as competent but ineffectual. Faced with the reality of looming insolvency and an inability to defend itself in an armed crisis, the kingdom had three options for salvation, all involving membership in a greater whole. One option was to continue as a member of an Austrian-led German Confederation, a choice that was greeted with skepticism by most Württemberg power-brokers, who justifiably mistrusted Austria, and particularly its chancellor, the silver-tongued Metternich. The alternative of being led by Austria's rival, Prussia, was also unattractive, primarily because the Württemberg government knew little of Prussia or its intentions, and Prussia's German policy was characterised by almost random initiatives, punctuated by profound indifference.

The most popular option, therefore, was closer cooperation with Württemberg's Mittelstaaten neighbours, leading to the formation of a Third German power to balance the two great powers. However, Third Germany was poorly defined, based on faulty assumptions and the incorrect belief that the four key southern states - Württemberg, Bavaria, Baden and Hesse-Darmstadt - would consistently act in the best interests of the 'greater good.' Thus, on the eve of the great liberal-nationalist upheaval that vocal panGermanists like Gagern had dreamt of for years, the Kingdom of Württemberg had no genuine conception of its place in Germany, an unclear understanding of what Germany 
was, and a decreasing ability to retain its own independent sovereignty. Such a precarious position would have grave consequences in the period between Gagern's attempts to form Germany in St. Paul's Cathedral in Frankfurt, and Bismarck's success in doing so more than two decades later, in the Hall of Mirrors at Versailles. 


\section{CHAPTER 5 \\ THE YeARS OF PropheCY AND CHANGE: 1848-1849}

NUMEROUS CRISES AND challenges faced Württemberg in the years since the Congress of Vienna. The state had stumbled through famine and numerous threats of war. Its economic system had been rocked by the shifting demography within its borders, and the changing nature of commerce between the German states as well as foreign powers. Wilhelm's ascension to the throne had caused the most sweeping changes to the Württemberg polity since its era of constitutionalism had begun in the sixteenth century. None of this upheaval, however, prepared the government for the emergency it would face in 1848. Caught up in the radical groundswell that spontaneously overwhelmed the other German states, not even the permissive liberalism of the state could help it avoid political chaos.

And yet, for all this, the state proved itself remarkably durable and adaptive. Throughout Württemberg's neighbours, governments crumbled and populations fell into open rebellion. In Württemberg, liberal-nationalists dominated the ministries, and the State Ministry was led by a republican, but these were changes and actions built around the crown's consent rather than its destruction. Wilhelm's early years showed him to be less than astute when dealing with the great powers, but remarkably able in creating an image that encouraged popular loyalty. The latter became more pronounced in this time of crisis; revolutionaries might have become preponderant in the political process, but control still rested in the hands of the king. This led to a number of unique circumstances. When a National Parliament was convened in Frankfurt, many of its leading members were Württembergers. The liberal-national movement also commanded broad support among the Württemberg electorate. Many of the leading members of the National Assembly (Nationalversammlung) that subsequently convened in Frankfurt were Württembergers, and liberal-nationalists commanded significant support among the Württemberg 
electorate. The support - both from the electorate and from Wilhelm - was, however, always conditional, and when the national project faltered in 1849 , the radicals in government were removed and replaced, again avoiding the bloodshed and reactionary repression that beset other states.

Thus, far from enacting profound change, for Württemberg 1848 was the beginning of over a decade constant political bartering and negotiation, both within the state's borders and in its involvement with its fellow German states. Ultimately, these manoeuvres lacked any direction, save the perpetuation of the stability of Württemberg itself. For all their promise of German unity, and for all the grand schemes of republicanism or federalism or mass liberal-nationalist reform, it remained unclear how 'Germany' would be created, what would constitute Germany, and how this would benefit Württemberg. What resulted from this upheaval, however, was an increasing sense of inevitability. German unification would occur, whether under radical or reactionary leadership. It was left to the states themselves to determine what that Germany would look like. This sense of inevitability, in turn, resulted from two remarkable years, in which revolutions and radicalism took the reins throughout Germany.

\section{Württemberg Politics on the Eve of Revolution.}

There was little evidence to suggest, before the revolutions began, that Württemberg's political leadership was in any danger. King Wilhelm was popular among his subjects, and had undone much of the damage caused by the despotic aspirations of his father. In particular, he had proven remarkably adept at building a support base from those who had become Württemberg subjects only as a result of the Federician expansion. While Swabians had previously identified strongly as Swabians, by 1826 they had adopted the proud catchcry: "Noi, i bin ä Wirtaberger" - "no, I am a Württemberger."' This Verfassungspatriotismus

\footnotetext{
${ }^{1}$ Karl Julius Weber, Reise durch das Königreich Württemberg (Stuttgart: J.F. Steinkopf Verlag, 1978), 144.
} 
also extended to a loyalty to the crown and the dynasty. As we have seen, the celebrations for Wilhelm's quarter-century jubilee were impressive and popular, but they were not the only public expressions of love of the royal family. When, in 1846, Crown Prince Karl married Grand Duchess Olga, the second daughter of the Russian Tsar Nicholas I, the Württembergers once more had reason to celebrate. When the couple returned to Stuttgart on 26 September, two months after their wedding, the streets of the capital were lined with uncounted thousands of onlookers and well-wishers. ${ }^{2}$

Part of Wilhelm's success came from his acceptance, and even encouragement, of liberal ideas. Unlike many other German monarchs, Wilhelm very rarely resorted to repression to stamp his authority on his state. In particular, Wilhelm's unwillingness to crack down on the Burschenschaften, though they were officially illegal, caused excitement abroad but general placidity at home. In 1824 , the permissive atmosphere surrounding the University of Tübingen, which had produced or nurtured many of the voices of German liberal-nationalism or Third Germanism - Wangenheim and List being only the most prominent - encouraged Berlin to ban Prussian students from enrolling in the institution. ${ }^{3}$ A decade later, Edward Disbrowe warned the British Foreign Office that the radicalisation of the universities was "the cause of the evil in Germany [that would be] difficult to cure." ${ }^{3}$ Regardless, Stuttgart continued to allow a degree of liberal engagement in the state bodies politic and social that other states would have found radical and dangerous. In the Landtag, liberal politicians began to make headway in matters of state policy as they gained mainstream political acceptance. Wilhelm's dissolution of the 1833 Landtag was an exception to the rule; with the subsequent political engagement of liberal-

\footnotetext{
2 Julius Hartmann, Chronik der Stadt Stuttgart: 600 Jabre nach der ersten denkwürdigen Nennung der Stadt (1286) (Stuttgart: Greiner \& Pfeiffer, 1886), 247.

3 Wynn to Canning, No.22, Stuttgart, 18 June 1824, in British Envoys to Germany, Vol.I, 357.

${ }^{4}$ Disbrowe to Palmerston, No.49, Stuttgart, 30 September 1832, in British Envoys to Germany, Vol.II, 365-366.
} 
nationalists such as Paul Pfizer, the Landtag took on a more progressive character. In some cases, that progressiveness extended even to the bastions of the Stände.

The changing fortunes of the Württemberg political sphere were epitomised by the election to the chamber in 1845 of the newest member of one of the great Württemberg political dynasties. Baron Friedrich Karl Gottlob Varnbüler von und zu Hemmingen was the son of Weckherlin's successor as finance minister, and his forebears had served on the privy council for centuries. Certainly, nothing in the younger Varnbüler's family lines suggested any deviation from the standard conservative particularism that one would expect from a state government minister. However, his studies of Jurisprudence, begun at Tübingen, had also taken him to study at the Friedrich Wilhelm University in Berlin, he had married into a highly influential Bavarian noble family, and he was soon to inherit a mechanised factory in Vienna. 5 Here, in a traditionally provincial and insular state, was a politician with an unusually broad experience of the 'German life.' Varnbüler was supportive of his monarchy, but equally aware of Württemberg's role in a greater German sphere. This political philosophy soon proved popular among both the public and the press. An editorial appearing in the Stuttgart daily Neues Tagblatt in July 1845 was profuse in its praise of the newly-minted representative. "He doesn't speak often in open sessions", the journalist noted:

but when he does his oratory is so gifted, as he himself is, that one gladly listens to him, and he presents his ideas as though they are immutable, yet he also displays a humility and a degree of contemporary learning that one would expect in Washington and Stockholm, in Brussels as in Paris. ${ }^{6}$

Benefitting not just from the progressive liberal influence but also from the modern conservatism favoured by a rising star like Varnbüler, the political outlook was promising.

\footnotetext{
${ }^{5}$ Fritz Hellwag, Varnbüler und die deutsche Frage 1864-1866, 3.

${ }^{6}$ Neues Tagblatt für Stuttgart und Umgegend, No.156, 10 July 1845. HStAS.P10 Bü.849.
} 
In German affairs, too, the government had achieved some measure of success. It had weathered the storms of the early 1830s, and as newsmen such as Siebenpfeiffer, Wirth and Schulz enthused in their broadsheets about the likelihood of a south German entente, there was little doubt that Württemberg would play an important role in whatever regional body eventuated.

Beyond its relatively open and enabling attitude towards political liberalism, the monarchy had done much more to earn the good graces of its subjects. Throughout the 1830 s and 1840 s, for instance, Wilhelm personally involved himself in a string of charitable projects, including a widows' fund, the Augustenpflege children's hospital, and the founding of several public parks. ${ }^{7}$ This was coupled with an improvement in the material wellbeing of Württemberg citizens. Healthcare improved dramatically as a result of government regulations, improved sanitary conditions, and the opening of several state-run hospitals, such as the aforementioned Augustenpflege or the Katharinenhospital. Conditions had so improved that fatal incidences of smallpox, which had peaked at an average of 32,000 per annum in the last decade of the eighteenth century, and 22,000 per annum in the first decade of the nineteenth century, averaged just 1,000 per annum during the first fifteen years of Wilhelm's reign. This was an admirable achievement, and certainly one that, to at least some extent, can be attributed to the royal family's patronage of the state health system. ${ }^{8}$

Even the economy appeared to be showing signs of recovery. In spite of the damage that the Zollverein would do to Württemberg's nascent state industries, the universalisation of import and export duties and border tariffs resulted in an immediate surge in trade; in the first year of Württemberg's membership in the Zollverein, the state's income from

\footnotetext{
7 Paul Sauer, "Stuttgart um 1840", in Wïrttemberg um 1840. Beiträge zum 150jährigen Bestehen des Württembergischen Geschichts- und Altertumsvereins, ed. Hans-Martin Maurer (Stuttgart: W. Kohlhammer Verlag, 1994), 108-109.

${ }^{8}$ Richard J. Evans, Death in Hamburg, 220.
} 
customs duties nearly trebled, and the treasury enjoyed steadily increasing profits from customs until 1848.9 Beyond this, the founding of the semi-official Society for the Promotion of Trade in 1830 indicates that the authorities were proactive enough to introduce measures designed to bolster Württemberg's economic performance. ${ }^{10}$

\section{Danger Signs of Radicalism.}

In spite of this liberalisation and modernisation of the political and economic climate, there were still many radicals who wished the reforms to go further. The electoral rights of the Württemberg Volk were relatively broad for their time, but there were still limitations. The Ludwigsburg Constitution allowed for tax-paying men over twenty-five years old to vote for their local representatives. Not only did this mean that the suffrage was restricted to directly electing just seventy of the ninety-three members of the Second Chamber (and none from the First), the suffrage itself was deceptively limited. Such restrictions permitted only thirteen to fourteen percent of the total Württemberg population to vote. When the constitution was adopted, this equalled approximately 200,000 people out of a population of roughly 1.5 million. This was significantly fewer than the working population of the state, which in 1835 stood at over 520,000.11 Moreover, anyone eligible to vote was also eligible to stand for election. This often led to lopsided electoral statistics. In the first elections of 1819, the village of Ehingen, in the district of Esslingen, had almost exactly the number of people vote as stood for the office they were voting for. In the contentious 1831 elections that brought Pfizer and the Hochwächter editors into the Landtag, the textileproducing town of Heidenheim an der Brenz, with a population of around 1,500, returned

\footnotetext{
${ }_{9}^{9}$ Dieter Langewiesche, Liberalismus und Demokratie, 34.

${ }^{10}$ Ibid., 36.

11 Hartwig Brandt, Parlamentarismus in Württemberg 1819-1870, 52; Gustav Schmoller, "Die Resultate der pro 3. Dezember 1861 aufgenommenen Gewerbestatistik”, in Württembergische Jabrbücher für vaterländische Geschichte, Geographie, Statistik und Topographie (Stuttgart: Verlag von Karl Aue, 1862), 283.
} 
a total of 204 ballots. Of these 204 voters, 197 were standing for the position of Heidenheim's local representative to the Landtag. ${ }^{12}$ This meant that a candidate could be elected with a 'majority', having accrued just three votes.

In spite of the liberalism of the state, Württemberg liberals soon faced a crisis of confidence, both from others and of themselves. The dissolution of the Landtag in 1833 was perceived as an attack on liberal politics by the monarchy. Rather than generating public sympathy for the liberals, however, this state of affairs presaged a devastating retreat. In 1838, when the Landtag elections again took place, the "very considerable" liberals whom Disbrowe had feared in the 1831 elections, and whom James J. Sheehan describes as "a substantial liberal minority", had all but disappeared. ${ }^{13}$ The essayist and Braunschweig newspaper editor Gustav Bacherer remarked that "it seems as though all political energy has dissipated, with the retreat of these men from the public eye." However, the sudden selfdestruction and "moral crisis" of the liberals by the end of the 1830s left the way clear for a far less divisive Landtag than had been formed in 1831, and this seemed to be viewed positively by the public. ${ }^{14}$ The Ministry of the Interior's political police retrospectively reported that, before 1848 , the state enjoyed an "enviable standing in public relations." "There was no talk of a republican movement", the reports concluded, "and the people were totally loyal to their royal house and in particular their regent, who expressed his love [of his people] in the highest order through just and well-meaning governance."15

\footnotetext{
12 “Die Wahl zur Ständeversammlung im Jahr 1819 (Oberamt Esslingen)”, StadtAE. I/2 Bü.3; Hartwig Brandt, Parlamentarismus in Württemberg 1819-1870, 59.

13 Disbrowe to Palmerston, No.8, Stuttgart, 15 February 1832. FO 82/26; James J. Sheehan, German History 1770-1866, 608 .

14 Gustav Bacherer, Süddeutsche Rufe aus Nord-Deutschland. Alle deutsche Ständeversammlungen und dem deutschen Volke. Nebst einer Antwort für den Fürsten Ludwig von Solms-Lich (Leipzig: Fest, 1839), 12; Brandt, Parlamentarismus in Württemberg 1819-1870, 602.

15 Württemberg Ministry of the Interior, "Wochenbericht”, Stuttgart, 24 November 1851, in Der Polizeiverein deutscher Staaten: Eine Dokumentation zur Überwachung der Öffentlichkeit nach der Revolution von 1848/49, ed. Wolfram Siemann (Tübingen: Max Niemeyer Verlag, 1983), 210.
} 
Wilhelm may have demonstrated "just and well-meaning governance", but dissent still manifested itself in frustration, rather than the overt actions against the government. Moreover, while republican activism may have been absent, this did not mean that there were not people who desired the dissolution of the monarchy. The most notable of these was the Landtag representative Friedrich Römer, who argued that Württemberg had become a "third-class power" under Wilhelm, lagging far behind Prussia and Austria. ${ }^{16}$ In 1845, Robert von Mohl's vocal campaign on a liberal-socialist ticket, campaigning largely for electoral and social justice reform, earned the wrath of the government. He was ignominiously stripped of his prestigious position as professor of Political Science at Tübingen, and demoted to administration at the less illustrious University of Ulm. ${ }^{17}$

Württemberg liberals, having endured their brief hiatus, were clearly returning to prominence by the mid-1840s. At least in the case of Mohl, this resurgence concerned the authorities enough to have him shunted to a less public role. Still, this was not enough to entirely quell the rising but gradual surge of popular discontent. Between 1846 and 1847 , Württemberg experienced an unexpectedly poor financial year, coupled with lower than average crop yields. Once again, the state was beset with food shortages, albeit far less severe than the Hungerzeit of 1816 and 1817. This, of course, was something that should have been alleviated by Württemberg's membership of the Zollverein, but in this case the customs union did not provide salvation. In spite of attempts by the authorities to maintain order, riots erupted in Ulm and Stuttgart. Unusually for Württemberg, these riots devolved into violence. In Stuttgart, Wilhelm himself appeared among the crowds in an effort to calm them, but he was met by a hail of rocks and insults, and was lucky to escape injury. ${ }^{18}$ In Ulm, two people were killed, while the soldiers who were called to the streets to disperse

\footnotetext{
${ }^{16}$ Jutta Köhler, Friedrich Römer als Politiker (Stuttgart: W. Kohlhammer, 1929), 15.

17 Donald G. Rohr, The Origins of Social Liberalism in Germany (Chicago: University of Chicago Press, 1963), 121.

${ }^{18}$ Lord Augustus Loftus to Palmerston, No.6, Stuttgart, 5 May 1847, in British Envoys to Germany, Vol.II, 403.
} 
the crowds "suffered severe contusions from Stones, the only Weapon which the Mob could command." The events caused Augustus Loftus, the temporary charge d'affaires at the British consulate in Stuttgart, to remark with wonder and concern at the fact that the people had responded with "anger and discontent" against "that Sovereign who had always been regarded with adoration by His People."19 The demonstrations were short-lived and, by the standards of the endemic protests in other states, they had been very mild in character. Nevertheless, they demonstrated that Württemberg was approaching some moment of rupture, between what the relatively permissive monarchy could accomplish, and what the increasingly restless opposition wanted it to accomplish. ${ }^{20}$

\section{The Stirring of Popular Unrest, 1847-1848.}

Wilhelm perceived the unrest in Württemberg to be the beginning of an outpouring of public frustrations. He also recognised that these frustrations were not a phenomenon unique to Württemberg. Writing to the Austrian general, Count Joseph Radetzky von Radetz, in November 1847, Wilhelm cautioned that Germany was experiencing “persistently restless sentiments." He also offered Radetzky a solution: “[N]onetheless, I believe that there is no reason for significant concern, providing the [German] governments remain united."21 The trouble with this, of course, was that Germany was not united at all. This was a sentiment he had previously expressed to Malet, noting that maintaining the health and wellbeing of the German states would be impossible so long as they were divided "into 38 morsels."22 Now, having experienced riots of his own, as well as having witnessed those occurring elsewhere, Wilhelm sought to remedy the situation. He urgently contacted

\footnotetext{
${ }^{19}$ Ibid., 403.

${ }^{20}$ James J. Sheehan, German History 1770-1866, 633.

21 Theodor Mästle, "Württemberg und die Großmächte vom Wiener Kongreß bis zum Tode König Wilhelms I. (1815-1864)” (Tübingen: Ph.D diss., 1951), 100.

22 Malet to Palmerston, Stuttgart, 16 October 1846, in British Envoys to Germany, Vol.II, 398-399.
} 
a succession of Prussian diplomats, suggesting in the strongest terms that Berlin should approach Vienna, with the aim of binding the two great powers into a treaty of defence and unity with the other Zollverein states. ${ }^{23}$ This was a bold move, given that Württemberg had negotiated with Prussia in 1831 to exclude Austria from German affairs. In 1847, however, Wilhelm saw his state's stability as being tied to the destiny of Germany itself.

Wilhelm had much to fear from a revolt, and he did not have to look far afield to see the dangers. In Baden, which was ethnically and geographically Württemberg's closest neighbour, chaos had been a rule rather than an exception. In 1819, the Jewish populations of Heidelberg, Mannheim, Karlsruhe, Bühl and Rastatt had been the target of popular violence. Residents of Tauberbischofsheim rioted in 1832. Those of the picturesque and distinguished university city of Heidelberg did so in 1838, and the jewellers of Pforzheim followed suit in 1839 , in protest against new state regulations governing working hours. ${ }^{24}$

Baden was the exemplar of what could happen when the population was inclined to dissent. Yet the region's cultural and political ties with France also made it susceptible to pressures from the west. The French propensity for protest and revolt acted as encouragement for disaffected Germans; such was the case when the citizens of Paris began rioting in February 1848. Though these uprisings occurred out of local frustrations and bourgeois animosity directed against the Orléans monarchy, their social roots - food shortages, politics not reflecting the popular will, and unfavourable financial conditions reflected the discontentment felt in Württemberg and elsewhere. ${ }^{25}$ Consequently, the French rebellion readily found an audience in Württemberg, in a manner in which the 1830 discord did not. Spontaneous Volksversammlungen (People’s Assemblies) convened in

\footnotetext{
${ }^{23}$ Heinrich Ritter von Srbik, Deutsche Einheit, Vol.I, 308.

${ }^{24}$ Otto Borst, Geschichte Baden-Württemberg, 200-201.

25 Geoffrey Ellis, “The Revolution of 1848-1849 in France”, in The Revolutions in Europe 1848-1849: From Reform to Reaction, eds. R.J.W. Evans and Hartmut Pogge von Strandmann (Oxford: Oxford University Press, 2002), 32-33; Mike Rapport, 1848: Year of Revolution (London: Little, Brown, 2008), 193.
} 
order to formulate demands for extended political freedoms from the Württemberg government. On 2 March 1848, a rally in Tübingen obtained over 1,000 signatures in a petition to the Stände. ${ }^{26}$ On the same day, a separate rally, convened in Stuttgart, delivered an ultimatum to King Wilhelm himself, urging the monarch to form a "Citizens' Council", presumably to permit a more direct political engagement than the limited suffrage. ${ }^{27} \mathrm{~A}$ fortnight after the beginning of these demonstrations began, the Schwäbische Kronik reported daily on the increase in demonstrations, assemblies, petitions and addresses, in all major Württemberg cities, towns and regions. These demonstrations, stretching from Stuttgart to the university city of Tübingen, the old imperial cities of Ulm, Rottweil and Reutlingen, and the financial centres of Heidenheim and Calw, demonstrate the widespread nature of the disorder. This was especially alarming, since such broad-based dissent had never been experienced in the kingdom's short history. ${ }^{28}$

These particular demonstrations were sudden and spontaneous, but Wilhelm had recognised the seeds of discontent long before they had sprouted. Consequently, he had had plenty of time to prepare a response. This response was rooted in compromise, and reflected Wilhelm's guiding principles of liberalism, order and the wellbeing of the state. On 9 March, he appointed Friedrich Römer to the office of minister of justice. Under the circumstances, this position was effectively that of the chief minister of the government. As a result, Römer, the arch-liberal republican, found himself forming government with a cadre of liberal-democrat politicians. A month later, upon the formation of the National Assembly at St. Paul's Cathedral in Frankfurt, Römer called statewide elections for representatives to the national parliament.

\footnotetext{
26 Bernhard Mann, Die Württemberger und die deutsche Nationalversammlung 1848/49 (Düsseldorf: Droste Verlag, 1975), 17.

27 Again, these measures manifested in the dissolution of the more liberal Landtag of 1831, but also in Wilhelm's response to the Hambach Festival of 1832, which was to illegalise political organisations. It should be noted that this was a common reaction throughout Germany; similar bans took place in Austria, Bavaria, Hesse-Darmstadt and Hanover. Schwäbische Kronik, No.62, 3 March 1848.

${ }_{28}$ Schwäbische Kronik, No.62-78, 3-19 March 1848.
} 


\section{The March Ministry and the National Assembly.}

It is tempting to assume that the rise of Römer and the liberal-democrats was due to the population growing tired of conservative monarchical powers. Römer, after all, was popular but radical, and was the most visible and recognisable exponent of the republicanism that the Ministry of the Interior believed did not exist. In the elections to the National Assembly, Römer won his Göppingen seat with some 96.3 percent of the vote; in Stuttgart, the journalist Paul Pfizer, one of the "ultra-radical" liberals of 1831, was elected to the assembly at St. Paul's with 96.1 percent. ${ }^{29}$ Römer was persuasive and charismatic, and his politics placed him in stark opposition to Wilhelm.

On the other hand, Römer did not rise to power on his own initiative, nor on a wave of public anti-monarchical opprobrium. On the contrary, it was Wilhelm who dissolved the previous government of Paul Friedrich von Maucler, and it was Wilhelm who placed Römer in power. His aim was to nip potential unrest in the bud, and had already proven himself remarkably proactive in this regard. Having failed in his attempts to forge a united German front against potential revolutionary violence, Wilhelm was justifiably concerned by the news of the Parisian revolts. Word arrived in Stuttgart of the Parisian uprisings on 27 February. By 1 March, even before any form of demonstration in Stuttgart or Tübingen, Wilhelm had issued a decree lifting censorship restrictions on the press. On $6 \mathrm{March}$, with popular unrest having barely gathered momentum, he sacked Maucler and his cabinet. ${ }^{30}$

\footnotetext{
29 It appears as though the election to the National Assembly caused some confusion within the electorate. In Römer's Göppingen district, for instance, some twenty-six voters, presumably mistaking the election to a national parliament with a referendum on the issue of Württemberg's leadership, cast their votes for King Wilhelm, whose name they had scribbled on the ballot. Bernhard Mann, Die Württemberger und die deutsche Nationalversammlung, 399-409.

30 There were some exceptions to this. Maucler was no longer in charge of state policy but he remained president of the privy council. Wilhelm also retained the services of Count Joseph Ignaz von Beroldingen, who had been foreign minister since 1823, and General Count Johann Georg Sontheim, the minister of war, who was also the bastard son of Duke Karl Eugen (and thus Wilhelm's first cousin once removed.) In spite of their survival in the new government, none of them would retain these positions by the end of the year. Malet to Palmerston, No.16, Stuttgart, 10 March 1848, in British Envoys to Germany, Vol.III, 311.
} 
Three days later, he had appointed the arch-liberal Römer as head of the so-called Märzministerium ('March Ministry'), to lead the country.31

Perhaps these should be seen as acts of desperation by a king deeply fearful of his position. However, Wilhelm proved time and again that he was a perceptive monarch, keenly aware of political realities, and unlikely to react with panic. In fact, he had preempted the violence that uncontrolled revolutionary fervour would invariably visit upon his state. Certainly, Württemberg's democratic traditions were no guarantee of peace and order. Baden's constitution, for example, was in word (if not deed) even more liberal and permissive than that of Württemberg, and its leader, Grand Duke Leopold, was universally hailed as an even-handed and mild ruler, but as we have seen, Baden was often crippled by riots. Perhaps Wilhelm felt that, by opening the floodgates while the river was still a trickle, he could avoid (or at least ride out) a torrent of rebellion that seemed inevitable, given the chaotic scenes in France. He was not the only one to believe that this course of action would avoid disaster. From the British consulate, Malet reported to Palmerston that

$$
\begin{aligned}
& \text { the promised concessions of the Crown will be legally carried out under the } \\
& \text { guarantee of a responsible Ministry, and the readiness which The King has } \\
& \text { shewn [sic.] in granting the popular demands [...] will not fail to create the } \\
& \text { best impressions both of His Majesty's good intentions and of His } \\
& \text { continuing to maintain the high character for circumspection and prudence } \\
& \text { which His Majesty has hitherto so richly deserved. }{ }^{32}
\end{aligned}
$$

If this is the case, Wilhelm was successful. Poor, hapless Baden dissolved into fullblown insurrection, greeted with perverse ecstasy by the more radical liberals who struggled to grasp power. Karl Mathy, a prominent liberal member of the Badenese Landtag who had

\footnotetext{
31 Brandt, Parlamentarismus in Württemberg 1819-1870, 617.

32 Malet to Palmerston, No.16, Stuttgart, 10 March 1848, in British Envoys to Germany, Vol.III, 311.
} 
previously been dismissed and exiled for his activist radicalism, saw the violence and propagation of armed liberal groups throughout Germany with profound joy. "I live [...] not among men, but among angels", he wrote ecstatically, "and I sleep in a fairy temple."33 The events in Baden were of such great concern to the rest of Germany that, by early April, it was planned to hastily assemble a collection of confederal armies, to enter Baden and restore order. Elsewhere in Germany, the scenes were no less violent. In Vienna, Metternich was unceremoniously deposed after just two days of revolt. When the news reached faraway Prussia, Berliners responded with ferocious riots of their own, demanding further liberalisation of the state bureaucracy and a relaxation of repressive laws against liberalnationalist movements. ${ }^{34}$ By April, the radical Mannheim liberal Gustav von Struve, assembling a force of several thousand rebels, declared his intent to topple the government in Karlsruhe as the opening gambit of a plan to bring about a national republic "following the example of the North American free states", which would constitute the "final victory of Christianity." ${ }^{35}$ Struve's moves were denounced in the Württemberg Landtag by David Friedrich Strauß, himself a Tübingen liberal and theologian; Strauß argued that a constitutional monarchy (albeit with federal reform) was the best possible outcome for the nation, and that Struve's actions endangered the order and wellbeing of Baden and the German national movement as a whole. ${ }^{36}$

Strauß exemplified the curious nature of the Märzministerium in Stuttgart. Römer was a more radical politician than Strauß, and as a republican-leaning liberal was at least mildly sympathetic to Struve's cause, but his ministry seemed content to pursue reform,

\footnotetext{
${ }^{33}$ Mathy was dismissed in 1834, and lived in Switzerland (the perpetual refuge for German liberal exiles) until 1840. Upon returning to Baden, he was elected to the Second Chamber, and took a leading role in Badenese activities at the National Assembly. This seems to have rehabilitated his political career, and he played leading roles in successive Badenese governments over the next two decades. Gustav Freytag, Karl Mathy: Geschichte seines Lebens, (Leipzig: S. Hirzel, 1870), 263; British Envoys to Germany, Vol.III, 482.

${ }^{34}$ Christopher Clark, Iron Kingdom, 471-475.

${ }^{35}$ Der Beobachter, No.39, 10 April 1848.

36 Schwäbische Kronik, No.109, 19 April 1848.
} 
rather than revolution. In spite of his pre-revolutionary rhetoric, Römer tempered his desire to dissolve the monarchy and nobility with an understanding that this desire may not be possible to achieve in reality. ${ }^{37}$ Consequently, the apparently radical government change in Württemberg had actually led to a circumspect state apparatus with a broad representation of the many different guises of liberalism. The violence and open rebellion that the liberals engendered in Baden were absent from its neighbour, and Württemberg liberals looked upon the more radical of their Badenese brethren with some distaste and even alarm. Regardless of the sudden rise of the liberals - some of them professing antimonarchical tenets - the state was considered such an oasis of calm that, when other states proposed a military occupation of Baden so as to avoid the brewing crisis between Struve and the Badenese army, it was Württemberg that was named as the staging point for the myriad German armies due to take part. ${ }^{38}$

What, then, did Römer and his colleagues of the Märzministerium hope to achieve? Beneath the placidity with which the state went about its business, there was significant underlying tension. Largely, this derived from two key problems. In the first place, Römer's administration was beset by conflicting ideas as to what the role of the state was. Reform at a state level was a laudable goal, but what measure that reform would take differed. Römer and Pfizer, the two most visible leading figures of the Württemberg government and its

\footnotetext{
37 In the event, Struve's 3,000 rebels were halted by troops dispatched from Frankfurt. Otto von Bismarck to Ludwig von Wildenbruch, Berlin, 25 September 1848, in C.E. Barrett-Lennard, Bismarck's Pen: The Life of Heinrich Abeken (London: George Allen \& Company, 1911), 118-119.

38 The operation itself is a somewhat complicated one. By 6 April, it had become apparent to the Badenese that troops were poised to invade; the Oberrheinische Zeitung of the next day claimed that the Württemberg troops already had crossed the border. This appears to have caused consternation in Württemberg, as their representative to Karlsruhe, Karl August von Wächter, reported, given that operations had not yet begun. Ralph C. Canevali claims that the confederal forces abandoned their plans as they were "baffled by the reaction of the people whom they had been charged to protect." In fact, as late as July, there were still negotiations between Württemberg and Bavaria at the very least, with the Bavarian War Ministry assuring their counterparts in Stuttgart that Bavaria could supply over 35,000 men for a peace-keeping operation into Baden, of whom approximately 11,000 would be immediately available. Oberrheinische Zeitung, No.98, 7 April 1848. HStAS.E50/01 Bü.765; Baron Karl August von Wächter to Karl Ludwig Friedrich Roser, Karlsruhe, 8 April 1848. HStAS.E50/01 Bü.765; Ralph C. Canevali, “The 'False French Alarm': Revolutionary Panic in Baden, 1848”, Central European History 18, 2 (June 1985), 139; Baron August von Rüpplin to Karl Ludwig Friedrich Roser, Stuttgart, 24 July 1848. HStAS.E50/01 Bü.765.
} 
representation at the National Assembly, broadly agreed that the Ludwigsburg Constitution should be overhauled to allow for a wider popular electoral suffrage, and both also saw the need for a relaxation of media censorship and other regulatory laws. Römer, however, saw this as being accomplished through the institution of republicanism and the abolition of the monarchy, while Pfizer believed that the same goals could be accomplished with the House of Württemberg still in place. These disagreements also extended to the national sphere. Both were liberal-nationalists who saw their role in state government and in the National Assembly as a means of bringing about the formation of a unitary nationstate. Once more, though, Römer favoured a federative republic not dissimilar to that favoured by Struve and his Badenese rebels. True to form, Pfizer argued for a German monarchy, led by the Prussian king and governed by constitutionalism. Other members of the Märzministerium, encouraged by the fall of Metternich, advocated a constitutionallybound, liberal reincarnation of the Holy Roman Empire, with Austria leading the way. ${ }^{39}$ This, then, was the fatal weakness of both Römer's Märzministerium and, indeed, of the National Assembly. In spite of the rise to power of the liberal factions of the various states, there was no common cause beyond the creation of a relatively liberal, relatively democratic Germany. Beyond this, consensus was elusive and fleeting. ${ }^{40}$

Both the Märzministerium and the National Assembly were 'revolutionary' bodies in their own right. The Märzministerium was the first true parliamentary government in Württemberg, with the government having previously been composed of the 'Government Party' (Regierungs-Partei), and the chambers of the Landtag having been largely advisory rather than truly legislative. The Frankfurt Parliament was a nationwide assembly of liberal-

\footnotetext{
39 Bernhard Mann, Die Württemberger und die Nationalversammlung, 85.

40 By November, the Württemberg consul in Frankfurt, Baron Karl von Sternenfels, had identified some nine factions within the Nationalversammlung, all with differing aims and objectives. Württembergers could be found in most of them at the time of Sternenfels' report, though membership was fluid and constantly changing. Karl von Sternenfels, "Die württembergischen Abgeordneten in den Fraktionen der Nationalversammlung (Oktober 1848)”, Frankfurt am Main, 1 November 1848. HStAS.E50/01 Bü.54.
} 
nationalists, the likes of which Germany had never seen. Both the Römer government and the Frankfurt Parliament had the principal aim of fostering a workable, truly national government, while the Württembergers had the secondary goal of reforming the state in an even more liberal fashion. In his secondary task, Römer was relatively successful, pushing a number of relaxed electoral and property laws through the Landtag, which expanded the electoral franchise. But neither Römer nor the leading member of the National Assembly, the Darmstadt liberal Heinrich von Gagern, succeeded in their chief objective. Frankfurt was an arena not of the cooperation towards a national greater good, as Gagern had envisaged, but rather was the scene of political rivalries, disagreements and dissent.

\section{The End of the National Assembly and the March Ministry.}

If the liberal-nationalists had jointly agreed on one conception of Germany, soon after arriving in Frankfurt, they might have been successful. The governments in all of the German states were in periods of upheaval. The disarray following Metternich's deposal was mirrored in Prussia, where the liberal government of Ludolf Camphausen, newly appointed to dissuade the population of the kingdom from descending into yet more violent rioting, set about drafting a constitution that would limit the monarchical power of the Hohenzollerns. Friedrich Wilhelm IV had even bowed to public opinion in many respects, appearing to support the national movement. ${ }^{41}$ If this national movement had been able to manifest itself effectively and quickly, it might thus have achieved a number of concessions. It did not. Favourable nationalist fervour reached its zenith in Prussia in March and April, when the king appeared before his people wearing the national colours of black, red and gold. It would not be until May, however, that the National Assembly even convened. ${ }^{42}$ In October the delegates in Frankfurt, after much debate, finally decided that the best form

\footnotetext{
${ }^{41}$ Christopher Clark, Iron Kingdom, 476-479.

${ }^{42}$ Ibid., 488-489.
} 
for the nation would be an inclusion of all German states, including Austria. Since this would be an application of Greater Germany, the National Assembly offered Vienna the stewardship of a united Germany. But the National Assembly had disastrously misread the situation in the Austrian capital. The revolution had been particularly violent throughout Austrian territory, with revolts in Vienna itself, as well as its provincial capitals. Throughout 1848, Austrian forces in Italy faced insurrections engineered by Piedmont; it was here that Radetzky earned his fearsome reputation. ${ }^{43}$ Further to the north, in June a Czech rebel shot dead Princess Eleonora Windischgrätz, the wife of the Austrian military governor of Prague. ${ }^{44}$ Some of the most violent episodes occurred in or were directly related to Austria's Hungarian territories. In mid-March, Hungarian liberals converged in Pest and Buda to demand political reforms that would give Magyars equal political, social and economic rights; though the initial demonstrations were largely peaceful, in September the new head of the Austrian armies in Hungary, Franz Philipp von Lamberg, was brutally murdered, sparking a bloody series of reprisals and skirmishes that lasted for more than a year. ${ }^{45}$ The initial Viennese uprisings had been directed against the repressive state apparatus, resulting in the deposal of Metternich and the flight of the Kaiser, Ferdinand I, to Innsbruck.

\footnotetext{
43 Italy endured significant violence throughout 1848 and 1849, with a variety of disparate Italian movements mostly fighting for local interests rather than an overall 'national' patriotism against Austrian rule — doing battle with Radetzky and his armies. Indeed, the word quarantotto (meaning 'forty-eight') soon entered the Italian vernacular, as an adjective to describe something chaotic but frivolous. For a good overview of Italy's revolutions, see Denis Mack Smith, "The Revolutions of 1848-1849 in Italy", in The Revolutions in Europe 1848-1849, 55-81, and Christopher Duggan, The Force of Destiny: A History of Italy since 1796 (London: Allen Lane, 2007), 169-180. An excellent case study that focuses on the Venetian patriot Daniele Manin is Paul Ginsborg, Daniele Manin and the Venetian Revolution of 1848-49 (Cambridge: Cambridge University Press, 1979); this work demonstrates the localised nature of even the most influential of the revolutionary movements. For an examination of the Italian 'national' movement led by Giuseppi Garibaldi, see Alfonso Scirocco, Garibaldi: Citizen of the World (Princeton: Princeton University Press, 2007), 138-181.

${ }_{4}$ Arthur Charles Magenis to Palmerston, No.19, Vienna, 15 June 1848, in British Envoys to Germany, Vol.III, 410-411.

45 R.J.W. Evans, "1848-1849 in the Habsburg Monarchy”, in The Revolutions in Europe 1848-1849, 187; Mike Rapport, 1848: Year of Revolution, 66-69, 305. As a Hungarian, Lamberg is referred to in Rapport's account by his Hungarian name, Ferenc, but in Austrian service he went by a 'Germanised' name. For the effect on other Hungarians in Austrian service, see Alan Sked, The Survival of the Habsburg Empire: Radetzky, the Imperial Army and the Class War, 1848 (London: Longman, 1979), 74-80.
} 
Eventually, the emperor returned to Vienna, only to once again flee in October (this time to Olmütz), when the army refused to march against the Hungarians. In the ensuing conflict, the capital was wracked with street-fighting, which only concluded at the end of the month when a reorganised Austrian army advanced on the poorly-provisioned rebels and forced their surrender. ${ }^{46}$

None of these events had anything to do with the National Assembly in Frankfurt; except for the first rumblings in Vienna in March, they had nothing to do with German affairs whatsoever. But the Viennese unrest had been a trigger, an inspiration for various dissenting groups throughout the Austrian Empire. In practice, this meant that Austria's 1848 was a long, drawn-out, bloody affair. It also meant that Austrian officialdom, when it regained the upper hand, was inclined to react decisively, to quell any further possibility of unrest.

The National Assembly's resolution therefore could not have come at a worse time. At the beginning of October, it sent a delegation made up of the activist Robert Blum and the liberal publicist Julius Fröbel. Both arrived in Vienna on 17 October, at the height of the chaos; the proposal was therefore presented to the rump parliament made up of the remaining liberals. ${ }^{47}$ Blum declared his support (and thus the support of the National Assembly) for the radical body. When the army restored imperial order, Blum was arrested on charges of inciting rebellion, and shot by a firing squad on 9 November. ${ }^{48}$ On the matter of the offer of national unity, Metternich's replacement, Felix zu Schwarzenberg, demurred.

\footnotetext{
46 R.J.W. Evans, “1848-1849 in the Habsburg Monarchy”, in The Revolutions in Europe 1848-1849, 194-195.

47 John Ponsonby to Palmerston, No.378, Vienna, 18 October 1848, in British Envoys to Germany, Vol.III, 419-421.

48 Fröbel escaped the same fate, although he, too, was found guilty in a military court. This was because he had previously written a pamphlet defending Austria's sovereignty even in the face of the German Question. As a result, he was pardoned, but exiled. Mike Rapport, 1848: Year of Revolution, 287-288.
} 
To do such a thing, he argued using the same logic Metternich had applied in 1815, would be to dilute Austria's sovereign power. ${ }^{49}$

The National Assembly's first attempt to build Germany and anoint its first leader had resulted in disaster. Not only had the offer been rejected, but the Assembly's representative had been killed, and the reputation of the parliament had been sullied by its association with the violent and rag-tag rebels of Vienna. Desperately, the Assembly turned to Berlin. It found no salvation there either. Friedrich Wilhelm IV refused what he called the "invented crown of dirt and clay." When he was visited by a delegation of deputies on 3 April 1849, he again rejected the offer of Prussian stewardship of Germany, writing later to his sister that he had been offered "something that can [not] be given" by "the man-donkeydog-pig-and-cat delegation." 50

Behind the Frankfurt liberal-nationalist experiment had been some of the finest and most forward-thinking political minds in Germany. But ambition, idealism and cleverness could not generate power from nothing, and when the Hohenzollern dynasty refused to hitch itself to the St. Paul's representatives, it effectively doomed the National Assembly. The most die-hard Frankfurt delegates accepted an invitation from Römer to reconvene in Stuttgart, and the first sitting of this so-called 'Rump Parliament' took place on 6 June 1849. But the retreat of the radicals to Württemberg was clearly the last gasp of the desperate, and even Römer soon became disillusioned with the entire process. The remaining parliamentarians were among the most belligerent, and they quickly issued a call for the creation of an "imperial regency" and a popular imperial army to defend the

\footnotetext{
49 Besides being a reactionary member of the nobility, Schwarzenberg had further reason to be skeptical of any nationalist radical movement - his sister, Eleonore, was the princess killed by Czech patriots in Prague. His brother-in-law, General Alfred zu Windischgrätz, encapsulated the Austrian government's Zeitgeist with his insistence that even moderate nationalists were rebels against the status quo, and "I don't treat with rebels." R.J.W. Evans, "1848-1849 in the Habsburg Monarchy", in The Revolutions in Europe 1848-1849, 196.

50 Walter Bußmann, Zwischen Preußen und Deutschland. Friedrich Wilhelm IV.: eine Biographie (Berlin: Siedler, 1990), 289.
} 
parliament. ${ }^{51}$ Unsurprisingly, these decrees did nothing to endear the Rump Parliament to the resurgent counterrevolutionary governments in other German states. Faced with the growing displeasure of his German compatriots - particularly the Prussian government under the foreign policy of the staunchly reactionary Joseph von Radowitz - not even Römer could permit the continuation of the very assembly he had saved from dissolution. On 17 June, not two weeks after the Rump Parliament first convened in the Halbmondsaal, Römer issued the assembly with an ultimatum. It was, he wrote, his "painful duty" to inform them that "the Württemberg government is in a position [in which] the imperial regency $[. .$.$] can no longer be tolerated." 52$ Thus, with little fanfare, the liberal-nationalist project that began with such promise and public excitement drew its final, ignominious breath.

It was a testament to Württemberg's institutional liberalism that the ultra-radical representatives from the Frankfurt Parliament, whose politics were so rebellious that many were charged in their home states with high treason, were accorded not just refuge, but also the ability to convene a new assembly in Stuttgart. King Wilhelm, furthermore, was keen for democratic reform of the German Confederation and, though he had on occasion used his monarchical prerogative, he could hardly be considered an authoritarian leader in the same absolutist sense as his Prussian or Austrian counterparts. Yet the Rump Parliament had abused his hospitality. Under the circumstances, Wilhelm (and indeed, Römer) could do little else but forcibly break up the assembly.

The end of the National Assembly also spelled the end for Friedrich Römer and his Märzministerium. They had come to power on Wilhelm's perception of a liberal-nationalist surge, and they had tied their fortunes to the Frankfurt Parliament. Now, the Märzministerium was a lame-duck government. In the August Landtag elections, the

\footnotetext{
51 Manfred Görtemaker, Deutschland im 19. Jahrbundert: Entwicklungslinien (Bonn: Leske Verlag + Budrich, 1983), 119.

52 Ibid., 120.
} 
selfsame liberal-democrats who had performed so well in the ballots the year earlier suffered humiliating defeats. As the Württembergische Zeitung reported, the public no longer wanted to see "a republican at the lectern." 33 In October 1849, Römer was replaced as head of government by the more orthodox Tübingen liberal Johannes von Schlayer, who himself was replaced just months later by a close ally of the king, Joseph Franz Peter von Linden.

With the fall of the Märzministerium, the brief, public-driven unification process in Württemberg also came to a close. King Wilhelm had appointed Römer as head of government because he felt Römer could act as a bridge between the state and what the public expected from national and state politics. Public approval of Römer and his liberalnationalist colleagues, such as Pfizer, was initially extremely high, as shown by their nearunanimous elections to the National Assembly. But the fate of the Märzministerium had been indelibly linked to the fate of the Frankfurt national project. When this failed, so too did the government in Stuttgart. Not until December 1870, when the national unification was a fait accompli, would the Württemberg electorate be as actively engaged in the state policy regarding the German Question as it was between 1848 and 1849. However, this does not mean that unification politics were removed from the state agenda. Over the course of the next several years, in fact, the creation of Germany would preoccupy the Neues Schloß. From now on, though, the issue would fall within the confidential purview of the state, rather than the public. Thus, while federation was still a popular option, from the fall of Römer until the Reichsgründung itself, the active process entered into by the Württemberg crown would be kept out of the public eye.

53 Württembergische Zeitung, Nr.30, 12 August 1849. 


\section{CHAPTER 6 \\ COUNTERREVOLUTION, REACTION AND REAPPRAISALS, 1850-1859}

GIVEN THE EXTRAORDINARY upheaval throughout Germany during the 1848 revolutions, it is unsurprising that the years following the defeat of the revolutionary elements were also characterised by confusion and conflict. Liberal nationalism had failed in Frankfurt to unite the German powers in any meaningful way. The demise of the National Assembly, however, did not equal the demise of the unification project. Instead, uniting Germany, which had been the objective of the national liberals, now became the tool of the conservative reactionaries who strove to restore stability and order to the German hinterland.

Prussia's self-imposed German isolation in the period between 1815 and 1848 had been punctuated by occasional flashes of importance. Its Zollverein, for instance, was one of the most groundbreaking economic reforms to be found in any region of the world at that time. The Zollverein was an exception to the rule; in general, a succession of leaders in Berlin saw it as more prudent to keep their heads down in matters of German nationalism. To some extent, 1848 changed this. The state's actions during the revolutions particularly sending the army to Baden to help quell armed rebellion - demonstrated a willingness to extend its influence somewhat further than its own borders. On the other hand, Austria had lost Metternich but not his ideas. Schwarzenberg was just as concerned about the dangers of German nationalism as his predecessor had been, and he saw Berlin's increased engagement in matters of pan-German security as a dangerous development. Schwarzenberg's line, similar to that of Metternich, was that Germany should not amalgamate into anything more binding than the German Confederation.

Somewhat paradoxically, however, the security and stability that both Austria and Prussia desired seemed only to come from concerted cooperation between one (or both) of these great powers, and the other German states. From late 1849, smaller states had begun 
gravitating towards Prussia, on the notion that only Prussia could offer the security needed by the resurgent but still unstable state governments. Prussia had, after all, not only intervened in Baden, but it had also interceded on behalf of the Saxon monarchy during the Dresden Uprising of May 1849. The Hanoverian government had been similarly assisted by Prussian force of arms. All the while, Austria had struggled with its own difficulties, and its influence on the smaller states and the Mittelstaaten had taken a back seat to that of Prussia. ${ }^{1}$ This culminated in Friedrich Wilhelm's "Erfurt Union", a proposed uniting of the German states, sans Austria, in a stronger, more binding relationship than the German Confederation. Ironically, this was precisely what the liberals at St. Paul's had (unevenly) aspired to, and this was the arrangement that the Prussian king had rejected, citing the artificiality of the "invented crown of dirt and clay", and the illegitimacy of the assembly that was offering that crown to Prussia. ${ }^{2}$

By 1850, however, circumstances were different from what they had been in 1848 . The Prussian status quo had recovered from the brief but intense liberal uprisings, it was capable of forming policy on its own terms without the interference of a revolutionary body, and for many of the smaller states that had suffered their own riots and revolutions in the last two years, Prussian oversight offered security and protection. Almost accidentally, then, Prussia took its first clear and realistic step towards becoming master of a federated German state modelled on the concept of Kleindeutschland. ${ }^{3}$ This, of course, Austria could not countenance. Nor, to some degree, could the Mittelstaaten. 1848 had been a spontaneous display of German solidarity and the desire for a German national state. This

\footnotetext{
${ }^{1}$ Heinrich Ritter von Srbik, Deutsche Einheit, 2.Bd., 22-24.

2 The Erfurt Union project had a mixed reaction from other European powers. In Whitehall, Palmerston saw a consolidation under a "liberal" Prussia as being a means of balancing out the powers of France and Russia. On the other hand, the Russians saw pan-German nationalism under any guise as a threat, since it had the potential to spread radical nationalist ideals from France into annexed Russian territories such as Poland. As a result, the tsar favoured the recreation of the German Confederation in its 1815 (or rather, 1819) form. Brendan Simms, Europe: The Struggle for Supremacy, 1453 to the Present, 217.

3 Geoffrey Wawro, The Austro-Prussian War: Austria's War with Prussia and Italy in 1866 (Cambridge: Cambridge University Press, 2007), 37-38.
} 
had allowed Third Germany to once more enter the national discourse. However, Third Germany would require specific circumstances to allow its formation, presuming that the fundamental difficulties of the concept could be overcome. While some opportunities presented themselves in the coming years, the outlook remained gloomy.

\section{The Hesse-Kassel Emergency.}

The difficult complexities of the national situation, coupled with the changing engagement of the powers in the German Question, were clearly illustrated by the Hesse-Kassel emergency of Autumn 1850. The affair involved the brief deposal of the elector, Friedrich Wilhelm I, by liberal-democrat deputies seeking to create and enforce a democratic constitution. By rights, this should have been an event of only minor importance. HesseKassel was one of the smaller Mittelstaaten, with fewer than one million subjects, and no economic or geopolitical importance to speak of. Nor should the liberals of the Kassel chambers have caused much concern. By this stage, the liberal-nationalist agenda throughout most of the German states was dead and buried with the failure of the National Assembly. Reactionary policies had by now taken hold in Prussia and Austria, as well as the majority of the Mittelstaaten, including Bavaria and Württemberg.

Perhaps surprisingly, Berlin welcomed the democratic surge in Kassel. This was not out of any residual Prussian liberal radicalism; rather, the deputies in the Hesse-Kassel Landtag were not averse to Prussian influence. Moreover, the elector had been an unpopular figure at home and abroad. To Prussia, then, the replacement of the elector by a liberal and constitutional parliament was not a threat but an opportunity, as it would not only stabilise state politics but also install a friendly government. The geographical position of Hesse-Kassel was also vital to Prussian interests. Two Prussian army thoroughfares ran through the small state, and the territory divided Prussia's holdings on the Rhine from its 
eastern heartland. ${ }^{4}$ As a result, Berlin was willing to send troops to Hesse-Kassel in defence of the parliament, since such a move would also protect its own vested interests. This development could hardly be countenanced by Schwarzenberg in Vienna who, having seen Prussia's police actions and the nascent Erfurt Union as a threat, could not very well permit the Prussian Army to occupy a state in what was (tenuously) the geographical south of Germany. Schwarzenberg thus appealed to the two most powerful of the southern Mittelstaaten, Bavaria and Württemberg. In October, King Ludwig of Bavaria, and Wilhelm of Württemberg, travelled to Bregenz to meet with the Kaiser, Franz Joseph. By 14 October it was decided to send a contingent of Bavarian and Württemberg troops into Hesse-Kassel to occupy the state on behalf of the elector and the German Confederation; by inference, the armies would also 'defend' Hesse-Kassel from any Prussian advance. 5

The measure was met with some reluctance. Wilhelm had no desire to come to blows with Prussia. Regardless of Hesse-Kassel's violent riots, the ascendancy of the Hessian liberals was not incompatible with Wilhelm's own political course in Stuttgart. Schwarzenberg's appeal, therefore, was to Wilhelm's mind simply a continuation of Metternich's policies of using the Mittelstaaten as proxies. Furthermore, even though Austria had reconvened the German Confederation, Vienna had no right under the confederal statutes to do so, let alone call for intervention in Hesse-Kassel. When the newly-reconstituted Confederal Diet met in September, no Prussian representatives were invited. This deliberate oversight breached three statutes of the Confederal Acts and thus made the formation of the Confederation unconstitutional. Moreover, the very act of sending an army to Hesse-Kassel, with the implicit aim of repulsing the Prussians, was in

\footnotetext{
4 A.J.P. Taylor curiously implies that Prussia entered Hesse-Kassel on behalf of Elector Friedrich Wilhelm. In reality, the opposite was the case. A.J.P. Taylor, The Course of German History, 100; Ralph Flenley, Modern German History (London: J.M. Dent \& Sons, 1959), 196; H.A.L. Fisher, A History of Europe (London: Edward Arnold \& Co., 1949), 928.

5 The leadership of this army was a joint initiative of Bavaria and Austria. Paul Sauer, Reformer auf dem Königsthron, 508.
} 
breach of Article XI of the constitution, which forbade the confederal members from using force against one another. ${ }^{6}$ Any one of these transgressions made any confederal decree null and void, and Württemberg could not be compelled to comply under the acts and statutes of confederal law.

Yet, for all Wilhelm's reluctance, the reasons for intervening in Hessian affairs outweighed these considerations. For one, Wilhelm was determined not to surrender his state's autonomy to the great powers, and he perceived the greatest immediate threat to be Prussia, not Austria. In spite of Schwarzenberg's Metternichian strong-arm tactics, Austria had been lethargic in its use of force in the preceding years. It was Prussia that still had soldiers in Baden, and it was Prussia now sending troops to Kassel, Marburg and Fulda. Wilhelm had never been entirely trusting of Berlin, and Prussia's newfound desire for German adventurism aroused his suspicions. Moreover, if Stuttgart and Munich were to commit to the Austrian plan to reinstate the elector, then Stuttgart and Munich would have a direct influence on the unfolding events. In other words, while Austria was using the southern states to do its dirty work, in doing so it was not imposing itself unilaterally on the rest of Germany, as Prussia seemed to be. The major actors in the affairs of one of the Mittelstaaten would be fellow Mittelstaaten.

Finally, given the precarious position of many of the southern states, even if Wilhelm had chosen to defend his sovereign prerogative and resist both Prussia and Austria, he lacked the political or military power to succeed without the support of the other Mittelstaaten, which were in no position to lend it. It was therefore inevitable that Wilhelm accepted Franz Joseph's plan, declaring in a toast to the Austrian emperor that "an old soldier does not make many words, but follows the call of the emperor, wherever that may take him." Franz Joseph acknowledged the good faith of his Württemberg ally, remarking

${ }^{6}$ Deutsche Bundesakte, Frankfurt a.M., 8 June 1815. 
that Austria took great pride in "going before the enemy with such brave comrades." fact, the very point of Franz Joseph's plan was that Austria would not have to "go before the enemy" at all; the fighting, if any eventuated, would be conducted by Austria's "brave comrades" but not by Austria itself.

Wilhelm's toast was made up of stirring words, but Württemberg's army took to the field unenthusiastically, and only then because the specific circumstances were favourable. In the event, Wilhelm's gamble was a good one. Friedrich Wilhelm von Brandenburg, Prussia's minister-president, died suddenly on 6 November, and with him died much of the Prussian zeal for the Hessian adventure. Two days later, the Bavarians and Württembergers marched across Hesse-Kassel's southern border and stumbled upon Prussian troops at Bronzell, five kilometres south of the city of Fulda. Both sides briefly traded shots, resulting in one casualty: a horse. ${ }^{8}$ Even this farcical 'battle' was enough for the new Prussian minister-president, Otto von Manteuffel, who had always been in favour of negotiating with the Austrians rather than antagonising them, and Berlin immediately sued for peace. ${ }^{9}$ While the elector was reinstated in Kassel, Vienna turned its attention to Prussia's terms. The resultant Punctation of Olmütz, signed on 29 November 1850, forced Prussia to formally renounce any independent German policy, in favour of deferring to a legitimised, reinstated German Confederation. ${ }^{10}$

\footnotetext{
7 Karl Johannes Grauer, Wilhelm I., König von Württemberg: Ein Bild seines Lebens und seiner Zeit (Stuttgart: Schwabenverlag, 1960), 300ff.

8 Paul Sauer, Reformer auf dem Königsthron, 508; Henry Richard Charles Wellesley, Baron Cowley, to Palmerston, No.395, Frankfurt a.M., 14 November 1850, in British Envoys to Germany, Vol.III, 98.

9 Manteuffel believed that Prussia had been provoked into intervening in Hesse-Kassel, so as to be discredited. This opinion was shared by the British minister at the Confederal Diet, Baron Cowley, who believed that "the Prussian Government fell into the snare, if it is fair to call it that." Cowley to Palmerston, No.395, Frankfurt a.M., 14 November 1850, in British Envoys to Germany, Vol.III, 98.

10 Wolfgang J. Mommsen, Das Ringen um den nationalen Staat: Die Gründung und der innere Ausbau des Deutschen Reiches unter Otto von Bismarck 1850-1890 (Berlin: Propyläen Verlag, 1993), 77.
} 


\section{The Resurgence of Third Germany.}

Wilhelm had little choice but to follow Austria's lead during the brief constitutional crisis in Hesse-Kassel, and certainly Württemberg was put in no great danger by his decision. However, though the German Confederation had nominally triumphed in November 1850, the affair had laid bare the deep divisions in the Confederation itself. Wilhelm had long campaigned for a revision of the Confederation's governing acts and composition. Two weeks before the Confederation reconvened (without Prussia) in September 1850, Wilhelm wrote an editorial for the Staats-Anzeiger, in which he warned that the Confederation was incapable of dealing with the modern political and social realities of Germany. The Confederation, he argued, was viewed by liberals, democrats and nationalists alike with distaste and derision. If the old Confederal Acts from 1815 were to be enforced once more, a new wave of radicalism and revolution would sweep Germany, demanding change and improvement. ${ }^{11}$ But such reforms were not part of Schwarzenberg's German policy. The agreement at Olmütz confirmed the primacy of the 1815 statutes, and Austria did not intend to alter them in any fashion. Thus, to the Württemberg government and crown, the unsatisfactory German Confederation had reasserted itself. Worse, the BavarianWürttemberg expedition into Hesse-Kassel had been nothing short of a declaration of war and an invasion in all but name; the statutes, therefore, appeared meaningless. In imposing what it called the Confederation's will, Austria had flouted innumerable laws governing that Confederation, yet would not be censured for doing so.

The humiliation of Prussia at the negotiating table at Olmütz also set a dangerous precedent. Austria, it seemed, would be given a free hand to pursue its own German policy, under the auspices of the German Confederation. Prussia, the single check and balance to Austrian domination in Germany, had been effectively emasculated. These developments were the inevitable consequence of the course of action that had been taken. Manteuffel,

11 Staats-Anzeiger für Württemberg, 18 August 1850. 
perhaps prudently, had been unwilling to push the Austrians further, lest he risk an all-out war for which Prussia was not ready. The reactionary forces that had propelled Schwarzenberg to power in Vienna could hardly be expected to behave otherwise. The Mittelstaaten had lacked the ability and will to resist. Now, however, the situation made resistance tempting. Metternich's course had led directly to revolution, and Schwarzenberg seemed content to follow the same political path, eschewing a strong Confederation in favour of maintaining Austria’s freedom of movement. ${ }^{12}$

All of these made for a compelling argument for the southern Mittelstaaten to once more evaluate the prospects of creating their own Third German Bund. This time, the Third Germanists returned to the question of what it was to be German. In the 1820s, Lindner's works had referred to the Mittelstaaten as "purely German states", and in the aftermath of 1848 , and again after 1850 , the question of 'purity' became even more prominent. At the heart of the reappraisal of German nationality was Austria. Previously, only certain Austrian territories - the German 'core' of the Empire - had been included in the German Confederation; even then, these lands included Bohemia, Carniola, Trieste and Istria. This meant that, though Austria contributed some 11.2 million people to the total population of the Confederation, barely half of those -5.62 million - were Germans, with another 5.24 million Slavs, and some 350,000 Italians. ${ }^{13}$ One of Schwarzenberg's aims at Olmütz was to have the entirety of the Austrian Empire officially recognised as part of the German Confederation. Manteuffel managed to force Schwarzenberg to withdraw his proposal, fearing that a greater population of Austrians in the Confederation would lead to

\footnotetext{
12 Pflanze indicates that Otto von Bismarck, then a young member of the Prussian Landtag, had mixed feelings about Olmütz. On the one hand, the agreement was an embarrassment for Prussia. On the other hand, it facilitated the avoidance of a costly war with Austria, one that Bismarck (and Manteuffel) felt Prussia could not yet win. Otto Pflanze, Bismarck and the Development of Germany, Vol.I: The Period of Unification, 1815-1871 (Princeton: Princeton University Press, 1990), 71-74.

13 Statistics here are taken from estimates calculated in 1843. Kann suggests, however, that these statistics may have been manipulated so as to give the Germans greater numerical representation in Austria. If this is so, it is possible that the German majority in Austria's confederal territories, however slim, may in fact have been a minority. Robert A. Kann, A History of the Habsburg Empire 1526-1918, 606.
} 
Vienna demanding a greater say in German affairs. Even so, the proposal was worrying to German nationalists. Austria's total population was roughly treble that of its confederal territories; of the approximately twenty million that Schwarzenberg wanted to add, most came from Austria's holdings in Galicia, Bukovina, Dalmatia and Hungary, where Austrian Germans were a clear minority. Therefore, Austria's full inclusion in the German Confederation would introduce an extra ten million Slavs, as well as five million Magyars and one million Rumanians. ${ }^{14}$ Schwarzenberg argued that the inclusion of the entire Austrian Empire would make the German Confederation "great, united [and] powerful", and he termed the resulting body a "Seventy-Million-Empire." But while Manteuffel had rejected the proposal on the grounds that it diluted Prussian representation in the Confederation, in the Mittelstaaten the greatest concern was that the German Confederation would no longer be German. ${ }^{15}$ Even Prussia, which had been at one point considered a "purely German Power", failed the ethnic litmus test. Prussian territories extended east, into Poland, and therefore included large numbers of Poles in East Prussia, Posen and Masuria. Of its seventeen million inhabitants, roughly two million were Slavs or otherwise not German. ${ }^{16}$

The problems of ethnicity were not just rooted in a racialised view of 'pure Germanness', though this certainly played a role in the deliberations of nationalist thinkers. Indeed, recent history had shown that ethnic divisions were dangerous, and tensions could easily turn into revolutionary violence. Austria's experiences in its provinces during 1848 and 1849 demonstrated the problems of far-flung territories encapsulating different ethnic communities. It was against the Czechs, Italians and Hungarians, after all, that the Austrians had the most difficulty maintaining order. Russia had found itself with similar

\footnotetext{
14 Ibid., 606-607.

15 Matthias Schulz, "A Balancing Act: Domestic Pressures and International Systemic Constraints in the Foreign Policies of the Great Powers, 1848-1851", German History 21, 3 (July 2003), 337-338.

16 Wolfgang J. Mommsen, Das Ringen um den nationalen Staat, 55-56.
} 
problems in Poland and, while Prussia's problems in its eastern province of Posen had reached their climax in the 1830s and stayed quiet ever since, there was enough of a precedent for Berlin to fear potentially rising Polish nationalist sentiment. ${ }^{17}$ The Mittlestaaten that made up the hypothetical Third Germany had no such considerations. None of them had expansive pretensions to a continental empire. Bavaria's claim on the Palatinate was the only example of the smaller states expanding beyond their core borders, and even then the Bavarians did not venture far. Here and there, there were small diaspora communities. Germans of Jewish descent, who at various times were considered to be something other than German, made up only a tiny proportion of the population; 60,000 could be found in Bavaria in 1850, thus accounting for less than 1.4 percent of the kingdom's population. ${ }^{18}$ Small émigré populations of French, Swiss, Russians and Italians dotted the other Mittelstaaten, but in no great numbers. ${ }^{19}$ The ethnic homogeny of the Mittelstaaten tallied with their actions in the post-1848 environment, leading to a general belief among the smaller courts that they, and only they, were working towards the general good of Germany. It was the Mittelstaaten that had come to the aid of the Confederation, since it was Bavaria and Württemberg which had sent troops to Bronzell, and it was these soldiers who had come under fire from the Prussian infantry. Furthermore, even though the radical liberals of 1848 were now gone from state government, Wilhelm and his

\footnotetext{
17 After the unification, the authorities in Prussia's Polish territories would find it necessary to deport some 32,000 Poles, on suspicion of stoking nationalist, anti-German sentiment. Christopher Clark, Iron Kingdom, 410-411; Helmut Walser Smith, "Authoritarian State, Dynamic Society, Failed Imperialist Power, 1878-1914", in The Oxford Handbook of Modern German History, ed. Helmut Walser Smith (Oxford: Oxford University Press, $2011), 310$.

18 Ian Kershaw, Popular Opinion and Political Dissent in the Third Reich: Bavaria, 1933-1945 (Oxford: Oxford University Press, 2002), 229.

${ }^{19}$ Saxony had extensive links with Bohemia, Switzerland and Poland as a result of the medieval and early-modern spread of the Saxons across Europe, as well as the personal union with the Duchy of Warsaw during the Napoleonic Wars. Nonetheless, these were issues of culture, not demography. Caitlin E. Murdock, "Tourist Landscapes and Regional Identities in Saxony, 1878-1938”, Central European History 40, 4 (December 2007), 600; D.B. Horn, "Saxony in the War of the Austrian Succession", The English Historical Review 44, 173 (January 1929), 33; Józef Andrzej Gierowski, "Centralisation and Autonomy in the Polish-Saxon Union”, Harvard Ukrainian Studies 3/4 (1979/1980), 271-284.
} 
government were keen to emphasise their democratic and constitutional credentials, while at the same time casting aspersions on the pedigrees of the great powers. Even before the Hesse-Kassel debacle, Württemberg newspapers had been emphasising the unique liberal qualities of the state. The state-run Staats-Anzeiger, for instance, ran a series of articles from 1850 and lasting well into the 1860s, declaring the constitutionalism of the kingdom to be far ahead of its fellow German states. The paper insisted that the "healthy political life" of Württemberg parliamentarianism was the result of Wilhelm's "prudence and wisdom."20 Constitutional heritages, it was implied, were to be found only in Württemberg and the other Mittelstaaten, such as Baden and Hesse-Darmstadt, and not in the great powers of Austria and Prussia, which generally acted only in their own interests.

Wilhelm continued to grow more and more jaded with the great powers. However, this does not mean to say, as one biographer has claimed, that "his mood darkened ever more [and] caution became suspicion and mistrust."21 Far from it: Wilhelm was destined to be frustrated, but this never stopped him from seeking out opportunities to promote his agenda as a liberal and nationally-minded monarch who sought to better his state's position. After 1850, he found a tentative ally in his eastern neighbour, Bavaria.

We have seen that Wilhelm, in his more adventurous youth, often reached further than his grasp in his relations with other German states. His attempts to take the lead in Third German and other regional developments in the late 1810 s and early 1820 s caused considerable bemusement and anger among his neighbours. Here was, after all, a middling power, attempting to act like a great power. Bavaria, on the other hand, was the opposite. Indeed, if any of the Mittelstaaten had a legitimate claim to predominance, it was Bavaria. Four times as large as Württemberg, and five times larger than Saxony or Baden, Bavaria was the largest of all the Mittelstaaten, and certainly the most powerful of the states that

20 Staats-Anzeiger für Württemberg, No.167, 14 July 1850; Staats-Anzeiger für Württemberg, No.40-41, 15-16 February 1850; Staats-Anzeiger für Württemberg, No.296, 14 December 1861.

${ }^{21}$ Peter Hoffmann, Die diplomatische Beziehungen zwischen Württemberg und Bayern, 9. 
would be involved in a Third German project. It is for this reason that it has been referred to as "a state between great powers and Mittelstaaten."22 Yet Bavaria had been reluctant to flex this regional muscle in the first half of the nineteenth century; only on occasion, as in the case of the Bavarian-Württemberg Customs League, did Munich take any measure that could be seen as provocative towards either Austria or Prussia. To some extent, its careful diplomatic positioning was shaken by the events of 1848 , and by the next year the press began to agitate against the great powers and for regional unity. "Not Austria, not Prussia - Germany is the solution!" proclaimed the Neue Münchner Zeitung on 3 January 1849, breaking with its previously ambiguous stand on the German Question. ${ }^{23}$ Revolutions may have convinced the Neue Münchner Zeitung's editors, but officialdom took another year. It was Austria's use of Bavaria as a proxy in Hesse-Kassel, and the subsequent agreement at Olmütz, that seemed to convince Munich that the years of cooperation with Austria were now over. Karl Ludwig von der Pfordten, the Bavarian minister-president, was especially scathing. Olmütz, he declared, had not been an Austrian victory. Instead, it had shown to the rest of Germany that Austria was little more than a petty bully, willing to place the lives of other German subjects in danger. Worse, it had even tried to water down the German Confederation into a polyglot union. "The hegemony of Germany is decided", he claimed boldly, "and Austria has lost." 24 To Pfordten, the initiative was now to be found in the capitals of the Mittelstaaten - and, in particular, in Munich. To his king, Max II, Pfordten wrote that Bavaria's primary mission was "to thwart any evisceration of Germany. Any political organisation that only benefits one of the two great powers endangers the independence of Bavaria."25 Pfordten identified the autonomy of Munich with the good of

\footnotetext{
${ }^{22}$ Manfred Hanisch, Für Fürst und Vaterland, 12, 152.

${ }^{23}$ Neue Münchner Zeitung, Nr.2, 3 January 1849.

${ }^{24}$ Heinrich Ritter von Srbik, Deutsche Einheit, 2.Bd., 89.

${ }^{25}$ Karl Ludwig von der Pfordten to Maximilian II von Wittelsbach, 2 March 1852, cited in Manfred Hanisch, Für Fürst und Vaterland, 152-153.
} 
the nation as he pictured it; this nation would not result from the stewardship of Austria, nor Prussia. In the coming years, Pfordten would become a close ally of Württemberg Third Germanists, though the closer involvement of Bavaria in matters of southern German regionalism - whose discourse had previously been dominated by Württemberg personalities such as Wilhelm and Wangenheim, would have significant consequences.

\section{Repositioning Württemberg in European Geopolitics.}

In many ways, 1850 had begun a new phase in the course of German nationalism. Württemberg, aggrieved by the events in Hesse-Kassel, now adopted a similar logic to that of Pfordten in Bavaria. The state was unwilling to follow any line - political, economic or otherwise - that would favour any of the great powers, since it was felt that this could only damage Württemberg's individual standing. In May 1851, for example, the Great Exhibition opened in London, and the Zollverein was amply represented. The Zollverein, of course, had been a Prussian initiative, and there is no denying the central place that Prussia naturally took. However, the emphasis on Prussia in the Crystal Palace incensed the Württemberg representative, Ferdinand von Steinbeis, who took it upon himself to erect a makeshift banner emblazoned with the word "Wurtemberg" over the Zollverein exhibit. Even more provocatively, both Württemberg and Saxony insisted upon their own, separate displays. It is a measure of the uncertainty in Germany at the time, or perhaps the relative strength of the Mittelstaaten (or the weakness of Prussia after Olmütz) that the Prussian delegation lacked the authority to demand that Steinbeis' banner be removed. On the contrary, the Württemberg government insisted that the success of its display at the Crystal Palace had been precisely because it had differentiated itself from that of the Zollverein. ${ }^{26}$

\footnotetext{
26 The 1851 display evidently caused some embarrassment. The Illustrated London News dismissed the German exhibition as "one muddy political stream", and German newspapers, such as the Augsburger Allgemeine, were less than impressed. The sharp disagreement between the Mittelstaaten and Prussia within the Zollverein therefore left something of a bad taste in the mouths of observers. Abigail Green, "Representing Germany? The Zollverein at the World Exhibitions, 1851-1862", The Journal of Modern History 75, 4 (December 2003), 847-848.
} 
Württemberg's stubbornness in London coincided with vigorous political manoeuvrings at the highest level. King Wilhelm was by no means blind to the realisation that, if Württemberg or, indeed, southern Germany was to stand independent of Austrian or Prussian hegemony, a third power - a foreign benefactor and protector - would be required to guarantee sovereignty and border integrity. The marriage of Crown Prince Karl to Grand Duchess Olga in 1846 had maintained the House of Württemberg's traditional ties to the Romanov dynasty, and in the early years of the 1850s Wilhelm sought to further strengthen those ties. Karl, he recognised with growing concern, was not at all ready to govern if Wilhelm died, and the king expressed constant dismay at Karl's "unemployment" and inability (or rather, unwillingness) to learn the trade of governance. ${ }^{27}$ Nonetheless, he quickly recognised that Karl and his wife were vital as instruments of diplomacy who could be used to maintain Württemberg's favoured position among its more powerful neighbours. In 1853 he presented the couple with the Villa Berg, a palatial stately home furnished in a decadent renaissance style, overlooking the exclusive northeastern quarter of Stuttgart. This home, to be Karl and Olga's royal residence until Karl succeeded his father, soon became a nexus of social activity. It was no coincidence that one of the most fêted early guests was Louis-Napoleon, the prince imperial and heir to France's Emperor Napoleon III. In another effort, after the death of Tsar Nicholas I, Wilhelm invited Empress Alexandra of Russia, the mother of his daughter-in-law, to take advantage of Württemberg's many spa resorts. Ostensibly, this was an act of kindness towards Olga, who suffered from acute homesickness. In reality, Wilhelm was eager to maintain the good

\footnotetext{
27 Hoffmann suggests that the "dark mood" she ascribes to Wilhelm's overall character was due to the fact that, approaching the twilight of his life, he was "unable to brighten the gloomy future through any illusions about the abilities of his successor, Crown Prince Karl." At least in this, the evidence suggests she is correct; in the years following the revolutions, Wilhelm became increasingly preoccupied with the fact that Karl was singularly unprepared to take the throne. Paul Sauer, Reformer auf dem Königsthron, 515; Peter Hoffmann, Die diplomatische Beziehungen zwischen Württemberg und Bayern, 9.
} 
graces of the Russian royal family. The invitation was graciously accepted, and Alexandra visited Wildbad for many weeks on three occasions, in 1856, 1857 and 1860.28

Beyond his efforts to bring his eldest son's marriage to diplomatic fruition, Wilhelm also attempted to cultivate bonds by marriage elsewhere. His youngest daughter, Princess Auguste, married Prince Hermann of Saxe-Weimar in 1851. The groom had close ties to the Dutch nobility, although admittedly Wilhelm had some misgivings about the pairing. In 1851 Wilhelm also took an active role in rescuing the failing marriage of his daughter Sophie to the king of Holland. ${ }^{29}$ In every instance, Wilhelm played an active role in fostering good relations with various European noble houses. The most important of these, though, were France and Russia, as is evidenced by the September 1857 Zweikaisertreffen, a conference of the two emperors of France and Russia, which was convened at the invitation of Wilhelm in Stuttgart. Between the discussions of international relations, Wilhelm acted as a gracious host. Napoleon III and Alexander II were guests of honour at the Cannstatt Folk Festival, and at night were entertained at a function at Karl's Villa Berg. The event indicates the high regard in which both the French and the Russians held Wilhelm, and the importance Wilhelm placed on good relations with the two. ${ }^{30}$

Of note, too, is the emphasis Wilhelm placed on good relations with his Mittelstaaten counterparts. Between 1852 and 1863, he hosted the Hanoverian royal couple; on many other occasions, he was visited by Max II of Bavaria. In return, the Bavarians accorded the Württemberg ambassador to Munich several privileges. In 1851, Ambassador Ferdinand Christoph von Degenfeld-Schomburg was invited to the royal gala and audience with the king on New Year's Day, even though the event was otherwise an exclusively Bavarian affair. ${ }^{31}$ The benefit of such behaviour is impossible to quantify.

\footnotetext{
28 Paul Sauer, Reformer auf dem Königsthron, 515.

${ }^{29}$ Ibid., 516.

${ }^{30}$ Napoleon III personally sent Wilhelm a letter of thanks afterwards, written in his own hand. Ibid., 547-549.

31 Aufwartung am Neujahrs-Tage 1851, Munich. HStAS.E50/05 Bü.162.
} 
However, this line of 'civil diplomacy', which Württemberg followed from 1851 to 1859 , kept Stuttgart's options open as Germany approached a moment of historic rupture.

\section{The Second Italian War of Independence - Third Germany's Best Hope.}

That moment seemed to arrive in April 1859 when Austria, growing increasingly agitated at the provocative military manoeuvres of the Sardinian armed forces in Italy, declared war. To Vienna's surprise, France entered the conflict on Sardinia's behalf. Almost immediately, the other great powers of Europe declared their own neutrality in the ensuing Second Italian War of Independence. ${ }^{32}$ This was the very situation that Third Germanists had dreamt of. The German Confederation rested on a precarious balance that was predicated on both great powers keeping each other in check, without one gaining the upper hand over the other. This system meant that Austria and Prussia maintained a perpetual war of nerves, in which it was in both of their interests to use the smaller states as instruments of their German policies, but also in their interests to act together so as to block any attempt by the Mittelstaaten to grow in power or stature..$^{33}$ Thus, any attempts by Wilhelm or Pfordten to forge a Third German alliance would almost certainly have failed, as long as the attention of Austria and Prussia remained on Germany. War in Italy, however, presented a unique and exciting opportunity. One of the two German great powers was tied up in a war with another major power. Prussia, meanwhile, had declared itself disinterested in the conflict. At least temporarily, the pressure of being caught in between two competing powers had lifted.

While Austria had been apparently taken by surprise by France's intervention, in Württemberg it had been predicted months or even years in advance. More than that, the Württemberg crown had been at the heart of the diplomatic negotiations that paved the

\footnotetext{
32 Stephen van Evera, “Offense, Defense, and the Causes of War”, International Security 22, 4 (Spring 1988), 28.

${ }^{33}$ Manfred Hanisch, Für Fürst und Vaterland, 152.
} 
way for France to go to war. At the 1857 Zweikaisertreffen, which Wilhelm had hosted, it had been decided that France would not support Austria in its adventures in Italy, and to that end Alexander had promised Napoleon a free hand to follow whichever course he saw fit. Thus, the Württemberg king was aware, some two years before war was actually declared, that France and Austria would likely come to blows over Italy, and Württemberg had wilfully played a part in facilitating the environment in which France would be capable of doing so. ${ }^{34}$

1858 was a diplomatically quiet year, but by the start of the next year, whispers of war made their way through Württemberg society. On 12 January 1859, Karl von Varnbüler's youngest daughter Hildegard, an avid diarist, scribbled in her journal that "presently much is being politicised here, for Austria and France threaten to go to war over Sardinia." 35 The rumours were not limited to the rarefied atmosphere of high social circles. In February, the newspaper editor Franz Hopf wrote a series of articles advocating a unified south German policy of armed neutrality, with conditional support for Austria if (and only if) the French resorted to an attack on the Austrian homeland. ${ }^{36}$ Hopf did not speak for the government, nor for parliament. But the nationalist liberal-democratic movement did hold at least some sway in the Landtag, and there was certainly some feeling of renewed pan-German optimism as Austria drifted towards war. The naming of Prince Friedrich of Württemberg as commandant of VIII Corps of the Confederal Army, for example, was hailed by Hildegard von Varnbüler as a positive development, because the prince was "extraordinarily

\footnotetext{
34 Paul Sauer, Reformer auf dem Königsthron, 549-550.

35 Hildegard von Spitzemberg, 12 January 1859, in Das Tagebuch der Baronin Spitzemberg 1859-1914 (Göttingen: Vandenhoeck \& Ruprecht, 1961), 41.

36 Compare this with Ambassador Disbrowe's report almost 30 years earlier, that Württemberg would even allow French troops passage through the Württemberg interior in the event of a Franco-Austrian war. Hopf's position, at least, suggests some confidence that the south German states could, in fact, band together to effect a serviceable defence policy, one that Disbrowe pointed out would have been impossible with Württemberg only acting unilaterally. Der Beobachter, Nr.30-32, 6-9 February 1859.
} 
well-inclined to Germany."37 At around the same time, the Landtag deputy Julius Hölder presented a proposal to "immediately assemble the National State and a representation of the people." Given Austria’s wandering attention, and Prussia’s ambivalence, Hölder's plea for "representation" could only have come from those states immediately in a position to offer such representation - that is, the Mittelstaaten. Naturally, the jurisdiction of the Stuttgart Landtag extended only as far as the Württemberg borders, and the chamber had no authority to impose any sort of will over other regions of Germany. However, the fact that the question was being debated in the chamber is significant, as is the result of the ballot. Though Hölder's resolution was soundly beaten (twenty-four for, sixty-seven against), it still invoked a positive reaction from more than a quarter of the assembled representatives. ${ }^{38}$ As war broke out, Hildegard von Varnbüler triumphantly wrote: "And so there is war! Probably all of Europe will burn now. God give us unity and victory!" In the circumstances, there can be little doubt that the "unity" and "victory" she longed for was that not of France and Sardinia, nor of Austria, but of the regionalist, Third German movement. 39

Regardless of the defeat of Hölder's motion in the Landtag, the Württemberg government might still have decided to press on with a southern federal project regardless. There was, certainly, a degree of Third German optimism within Wilhelm's ministers. Perhaps this was the moment that a south German Bund could break free from Austria's shackles. But such a development required decisiveness and coordinated political action between willing would-be member states. Here, the enthusiasm began to dissipate. Hugo von Spitzemberg, the Württemberg ambassador to Paris, sent his ministry a confirmation of the neutrality of both Great Britain and Prussia, as reported through the medium of the 3

\footnotetext{
${ }^{37}$ Hildegard von Spitzemberg, 14 April 1859, in Tagebuch, 41.

38 Dieter Langewiesche, Liberalismus und Demokratie, 286.

${ }^{39}$ Hildegard von Spitzemberg 29 April 1859, in Tagebuch, 42.
} 
May edition of the Paris daily newspaper, Le Moniteur. This was all well and good, but what had alarmed Spitzemberg enough to underline and annotate one passage was the weak denial of Napoleon III that he had concluded a treaty of alliance with St. Petersburg. "In a time when all of Europe [is embroiled in] military or naval armaments on a large scale", Le Moniteur declared, "the Emperor must provide for contingency measures." 40

To Spitzemberg — and likely, to Wilhelm — the passage was vague and concerning. What contingencies had Napoleon planned? Perhaps the French army intended to march into south Germany and attack Austria from the north, as it had planned back in the 1830s. If that was the case, what would be the best countermeasure? To form Third Germany and declare neutrality? Or to side with Austria and use Vienna as a protective force? Or was Napoleon's "contingency measure", in fact, an alliance with Russia, which had been rumoured for some days? As Hildegard von Varnbüler had noted presciently on 27 April, having heard the rumour herself, "that would be very bad for us!" 41 Indeed it would, for a Franco-Russian alliance would leave Germany surrounded. The results of that would be unpredictable. Perhaps the two powers would decide, having beaten Austria, to invade Germany proper. But under what circumstances would Württemberg answer the call to arms? Both conservatives and democrats couched themselves in a truce of nebulous terms over the issue: Württemberg would act in defence in the case of an "attack of a foreign power upon Germany", but now that too became a difficult point to agree on, given that Germany was still a vague concept. An attack on Württemberg itself would necessitate a call to arms, but how far beyond the border did this responsibility extend? To the Grand Duchy of Baden, nestled between Württemberg's westernmost border and France's easternmost? To Hamburg, far to the north at the mouth of the Elbe? To Prussia or Austria

\footnotetext{
${ }^{40}$ Le Moniteur, 3 May 1859. HStAS.E50/01 Bü.875.

${ }^{41}$ In the same journal entry, the young countess reported that the Royal Navy had put to sea and was heading for the Mediterranean to enter the war, presumably on the French side. This, of course, was nothing more than a spurious rumour. Hildegard von Spitzemberg, 27 April 1859, in Tagebuch, 41.
} 
(or Prussia and Austria)? What would cause such an intervention? As the war progressed, Napoleon III became increasingly certain that the German states could band together and strike towards Paris as a supporting action on Austria's behalf.42 But Hopf, and a number of the deputies in the Landtag, would have countenanced such a move only if France attacked Austria, while others were interested only if the hypothetical French move threatened Württemberg proper.

Austria's frequent adventures in its far-flung territories complicated the matter even further. Hopf insisted that only the Empire's core - being the German Austrian territories - was subject to the southern states' defensive guarantee. And even then, there was the matter of which states would actually take part in this defensive southern federation. HesseDarmstadt was usually counted as a member of the still-hypothetical Third Germany, but Prince Alexander, the third son of the Grand Duke of Hesse, was a serving officer in the Austrian army, which the Württemberg ambassador in Vienna, Baron Adolf von Ow, reported with some disdain. ${ }^{43}$ Finally, though Third Germany had been a mooted option for German unification since the founding of the German Confederation in 1815, as we have seen the proponents of such a system - or, indeed, of any model of united Germany - had yet to formulate a clear, concrete plan of administration. In short, the Second Italian War of Independence offered Third Germany its best opportunity yet, but in spite of that it was not clear whether Third Germany would be permitted to exist by France or Russia, let alone Austria or Prussia, nor what Third Germany would actually comprise.

As always, however, the main challenges facing the Württemberg Third Germanists was a lack of time and a lack of cohesion. None of the aforementioned difficulties were necessarily insurmountable providing that sufficient effort was expended in solving them.

\footnotetext{
42 Arnold Blumberg, "Russian Policy and the Franco-Austrian War of 1859", The Journal of Modern History 26, 2 (June 1954), 150.

43 See, for instance, Baron Adolf von Ow to Baron Karl Eugen von Hügel, Vienna, 12 July 1859. HStAS.E50/01 Bü.875.
} 
But it would take time for a federation to be formed, it would take time for statutes to be agreed upon, and it would take time for a south German federation to negotiate with Paris and St. Petersburg to guarantee their neutrality in the matter. The longer the Second Italian War of Independence continued, the more Austria would have to dedicate to the conflict, and the less inclined Vienna would be to meddle in south German affairs.

If Wilhelm and Linden were devoted to the cause of Third Germany, then they had to act quickly, and they would hope that the war in Italy was a long, arduous affair. But Wilhelm had learned from his early years on the throne that rash actions and words could have unintended, negative consequences. On the other hand, his cautious planning on the eve of the 1848 revolutions had proved a masterstroke. Perhaps taking the lesson too far, Wilhelm's reign throughout the 1850 s was careful to the point of vacillation. His hosting of the Zweikaisertreffen in 1857 was the exception to the rule; in 1858, Pfordten had approached him with a plan to propose confederal reforms that would have at least partially marginalised the power of Austria and Prussia in the Diet. Wilhelm, however argued that it was better for the political situation to stabilise and very gradually alter, than to be thrown into sudden tumult by an ill-advised Bavarian show of political force. ${ }^{44}$

This cautious positioning may have been prudent in 1858 , when a clear opportunity to shake up the organisation of the German Confederation did not exist outside of the hopeful planning of Pfordten and Max II. By April 1859 it was a liability. Gradual change became stagnation. Immediate action was vital, and Stuttgart simply was not willing to undertake it. The one saving grace could be if France perpetuated the war, allowing Wilhelm time to change the political course of his state. But here, too, the erstwhile monarch was frustrated. Austria's armies, supposedly the most impressive in Europe, performed extremely poorly in the Italian theatre. Austrian soldiers proved themselves totally inept with their new Lorenz rifles. They lacked the morale, the training and the

44 Paul Sauer, Reformer auf dem Königsthron, 551. 
leadership to resist concerted French bayonet charges. The instructional tactical manuals distributed among units were far too complex to convert into practice. Since most officers were German while the rank-and-file soldiers were not, order on the battlefield soon dissolved, as Slovenes or Hungarians could not comprehend even the most basic commands issued by their officers because they simply did not understand the language. ${ }^{45}$

Had the Austrians troops faced an effective, modern and well-maintained foe, they would surely have surrendered, or else have been bloodily defeated. The fact that this was not immediately the case speaks volumes for the state of the French army. Napoleon III's troops entered Italy in arguably as poor a condition as their Austrian opponents. From Genoa, at the height of the war, the emperor complained of the error of sending French troops into Italy "before having stocked up any supplies there. This is the opposite of what we should have done." 46 At Solferino and Magenta, the pivotal battles of the campaigns, both sides took heavy casualties. Nominally, both battles were French victories, but they were essentially inconclusive. For all the fervour with which Vienna and Paris declared war on one another, the Second Italian War of Independence degenerated into a quagmire with little of benefit to either. Austria was neither willing nor able to hold on to its rebellious Italian territories indefinitely. Ceding them to the Italian nationalists very quickly proved the lesser of two evils.

For his part, Napoleon was keen to beat the Austrians on the battlefield, but he was not interested in upsetting the balance of power in Europe by driving the Austrians back towards the Danube, especially since he was as uncertain about the German Confederation's obligations to Austria as the Confederation's member states were themselves. Napoleon fought a limited war with limited aims, and Austria was able to retreat from the field with a tremendous blow to prestige but little significant damage to its

\footnotetext{
45 Geoffrey Wawro, The Austro-Prussian War, 11-12.

46 Michael Howard, The Franco-Prussian War: The German Invasion of France, 1870-1871 (London: Routledge, 2008), 17.
} 
political position in Germany. This was clearly not the crushing blow to a German superpower that Third Germany needed in order to exist. By the time the two exhausted powers sued for peace in Villafranca, just three months after the outbreak of the war, the opportunity to alter Germany's destiny had slipped from south Germany’s grasp. Writing an urgent telegram to the Ministry of Foreign Affairs, the diplomat Karl August von Wächter could hardly keep the bitter disappointment out of his terse, curt message. Addressing the telegram to "His Majesty the King", Wächter reported: "La paix est signée" "The peace is signed." 47

\section{The Beginning of the End?}

1859 was the culmination of a turbulent era of socio-political change, begun in 1848 , that affected all of Germany, and particularly the Mittelstaaten. What these years signified, however, is debatable. In some ways, the short answer is 'nothing.' In Frankfurt, the National Assembly was killed off by its own inertia and indecisiveness, and liberal nationalism died a painful, symbiotic death with it. At a state level, Römer's March Ministry promised much by way of state reform, but achieved very little. Römer's inability to divorce himself from the farcical gathering in St. Paul's led to his own downfall. Thereafter, Württemberg returned to the conservative status quo, and Germany once again fractured into its multiplicity of states.

This reading of the situation, however, does not do justice to the complexity of the situation. It is true that Gagern and Römer failed. But 1848 proved beyond a shadow of a doubt that the German identity, whatever that meant to each individual German, was a strong and influential motivator. It is significant that every German state underwent nationalist upheaval. Even Württemberg, with a strong emergent particularist identity and a popular loyalty to the crown, was caught up in the fervour of bargaining away the

\footnotetext{
47 Wächter to Hügel, No.1466, Paris, 12 July 1859. HStAS.E50/01 Bü.875.
} 
sovereignty of that particularism in favour of national unification. Whatever the failings of the National Assembly or the Märzministerium, in the public eye German nationalism was profoundly significant.

The other important lesson to be gained from the 1848 revolutions was that national unification was, by now, all but a certainty. Indeed, the crises of 1848 and 1849 were not only caused by a desire for unity; in many cases, those who combatted the radical upheavals saw unity as the only solution to the crises. Thus, Wilhelm warned Radetzky months before the revolutions began that they could be avoided only through the unification of the German governments. Similarly, states turned to their neighbours for security, as in the case of the Hesse-Kassel emergency, or the abortive Erfurt Union. The most audacious attempts to set German states of a course of unification, however, could be found in the south. In Württemberg a series of initiatives by both government and press established the proud, particularist, constitutional heritage of the state, and by inference defined that heritage as part of a regional national body, based among the Mittelstaaten and distinct from the experiences of the Prussians or Austrians. These efforts corresponded with developments that seemed to disqualify Prussia and Austria as the guiding lights of German unity. In Prussia's case, the humiliation at Olmütz had caused Berlin to reassess its position in Germany. Vienna's leadership, on the other hand, seemed to necessitate subordinating Württemberg's sovereignty to Austria, as was the case during the Hesse-Kassel emergency. As a result, and recognising that unity was increasingly desirable for stability and security, Württemberg chose to strengthen ties between the Mittelstaaten, and between Württemberg and other powerful, non-German states, such as France and Russia. The catalyst for Third Germany seemed to come in 1859 with the outbreak of war between Austria and France. However, without clear direction from a government that appears to have been too cautious, and with little understanding of the practicalities of forming a new German federation, Württemberg's competent willingness to do so soon collapsed. In any 
event, the opportunity that the war presented was merely an illusion. ${ }^{48}$ As the decade ended and brought these tumultuous years to a close, it seemed that, for all intents and purposes, the Third German project had ended before it had even begun.

${ }^{48}$ Dieter Langewiesche, Liberalismus und Demokratie, 288-289. 



\section{CHAPTER 7 \\ SIX YEARS OF AUTUMN: 1860-1866}

THE YEARS OF 1848 to 1859 fundamentally changed the dynamic of Germany and the destinies of the German states. They also tilted the balance of power in the region, although this was not immediately apparent. For all of the revolutionary fervour of 1848 , for all the furious manoeuvres of 1850 , and for all the uncertainties of 1859 , the 1860 s began with the appearance that little had changed. Austria had reimposed its power over the German Confederation and had vociferously challenged the liberal-nationalist movements to the point where they had crumbled. Nothing, however, could have been further from the truth. Austrian power in Germany had begun an inexorable decline. 1848 had shown the popular significance of a German Fatherland and, regardless of whether Heinrich von Gagern and the idealistic liberals of the Frankfurt Parliament had failed in their objectives, the national question had taken centre stage in 1848 and would continue to do so until the ultimate unification in 1871.

If Austria wished to abandon Metternich's course of subverting the nationalist cause, its time to foster a großdeutsch bonhomie among the Mittelstaaten and smaller states was alarmingly short. 1848 had shown that the Hofburg was not immune to revolutionary pressures. The Hessian constitutional crisis of 1850 had proved that Schwarzenberg, like Metternich, was willing to act contrary to the greater good of the public in order to reinstate the status quo, since the elector of Hesse-Kassel and his ministers were hardly on good terms with their subjects. The Hesse-Kassel affair had also underscored potential difficulties between Austria and its south German allies, whom it had previously considered assiduously dependable. Stuttgart and Munich had been reluctant to send their armies to return the elector to power and, while the shooting match with Prussian soldiers was brief, the south German governments found themselves questioning Austria's motivations in tying itself to south Germany. That these south German governments seriously considered a 
final split with Vienna while Austria struggled with France over Italy was more significant than the fact that these efforts came to naught.

Finally, while Austria was beginning to show its failings in the German sphere, its Prussian rival to the north was doing the opposite. Prussia had shown no inclination towards a coherent German policy in the early half of the nineteenth century, but this was slowly changing. The Erfurt Union was a prototypical national body, more binding than the Confederation. Again, its failure is less significant to us than the fact that it was attempted in the first place. Moreover, Prussia's actions in Baden in particular, and later its short-lived defence of the revolutionary Kassel parliament, demonstrated the emerging resolve of Prussia to participate in the affairs of other German states.

\section{Renewed Regionalist Agitations: The Würzburg Conferences, 1859-1861.}

Almost unwittingly, Germany entered the 1860 s on the cusp of extraordinary change. These were hardly auspicious times, particularly for the would-be Third German states. On the one hand, the relations between these states and their regional betters, Austria and Prussia, as well as other European powers, had worsened, particularly during the course of 1859. The confused state of affairs in Italy, and the diplomatic intervention of the British and the Russians in particular, had undermined the south German debates on breaking with Austria before they had adequately begun. This was not, however, immediately fatal to Third German aspirations, in spite of all appearances to the contrary. In November 1859, four months after the Second Italian War of Independence ran its course, Bavaria hosted a conference of the Mittelstaaten in the picturesque, medieval Lower Franconian town of Würzburg. This conference was intended as a means for the Mittelstaaten to form a cohesive policy of approaching confederal reform, along the same lines as that suggested by the Bavarian government to the Württembergers a year earlier. ${ }^{1}$ The conference soon ran into

\footnotetext{
${ }^{1}$ See Paul Sauer, Reformer auf dem Königsthron, 551.
} 
difficulties along the same lines of disagreement that previous Mittelstaat initiatives had; nevertheless, the leaders of these states were not dissuaded from pursuing further reforms through the auspices of a common Mittelstaaten alliance. Consequently, another conference, again to be held in Würzburg, was arranged for July 1860. This conference differed from the first, insofar that the first had attempted to tackle the question of comparative law and jurisprudence, while the second Würzburg Conference was a meeting of the ministers of war of the various Mittelstaaten. This was a provocative move, and this time it was not an initiative of the 'usual suspects' of Third Germany, Bavaria or Württemberg. Instead, it was the Saxon minister-president, Count Ferdinand von Beust, who initially invited the Württemberg government to send its war minister, LieutenantGeneral Moriz von Miller, to a meeting with his Saxon opposite number, Adolf Bernhard von Rabenhorst. Saxony's sudden interest in the German Question, and its potential involvement in a regionalist project that would involve neither Austria nor Prussia, was evidently an opportunity Wilhelm could not afford to pass up. By the next day, Stuttgart was making preparations for Miller's departure. ${ }^{2}$ The Württemberg government clearly saw the benefits of the proposed meeting. So, too, did the other Mittelstaaten governments, who sent their own representatives. ${ }^{3}$

What the ministers in Würzburg proposed was military autonomy of the Mittelstaaten, free from Austrian and Prussian dominance. This had become increasingly pressing in the previous decade. The movement of Württemberg and Bavarian troops into Hesse-Kassel in 1850 had not been popular among Württembergers or Bavarians, but they had been compelled to do so by the Austrians. In June 1859, an editorial appeared in the Wiesbaden daily Rhein-Lahn-Zeitung, which declared that "Germany must not be permitted to allow Austria to stand alone in this current war" - which, after all, was

\footnotetext{
2 Count Ferdinand von Beust to Hügel, Nr.57, Dresden, 19 July 1860. HStAS.E50/01 Bü.877.

3 The one exception to this was Baden, which did not take part.
} 
precisely what was being suggested in Stuttgart at the same time. The correspondent's solution was, perhaps, ridiculous in the circumstances, but embodied much of what the south German states feared. In order to save Austria, the Rhein-Labn-Zeitung insisted, Germany must act as a faithful ally to Vienna, with "the diplomatic and military leadership of the whole, non-Austrian Germany [...] placed in the hands of Prussia." ${ }^{4}$ The journalists in Wiesbaden, it seems, could not see any objection to a continued joint stewardship of Germany, albeit strengthened above the current powers of the German Confederation. In a sense, their calls for German unity were as idealistic as those of Gagern and his compatriots in Frankfurt, and equally as unrealisable. "We don't need a Confederal Council of War", the article continued, "[for] the war protocols of the German Confederation are completely useless for all but a lame, pretend war." Instead, victory, safety and stability could be achieved through a simple appeal to German unity. "How quickly all misconceptions and misunderstandings would disappear, like mists before the dawn", the correspondent wrote, with the typical flourish of the liberal-nationalists, "if only we now sat, North and South together, in one single, German parliament!"s The time for such ideas, however, had long passed. It had become clear in the preceding decade that Austrian and Prussian interests would inevitably clash, and any großdeutsch solution to the national question could only be accomplished if the governments in Berlin and Vienna underwent fundamental change. In short, the single German parliament envisioned in the Rhein-Lahn-Zeitung, under existing conditions, could only take the form of the Confederal Diet - far looser than the proponents of Großdeutschland or the Wiesbaden journalists hoped.

Even presuming that Prussia and Austria could come to some arrangement, there were signs that the southern German states were not amenable to reconciliation with Austria. The Württemberg ambassador to Vienna, Ow, did little to mask his dismay at the peace

\footnotetext{
${ }^{4}$ Rhein-Labn-Zeitung, No.94, 22 June 1859.

${ }^{5}$ Ibid., emphasis in original.
} 
talks being held between Kaiser Franz Joseph and Emperor Napoleon III at Villafranca in July 1859, nor had he been charitable in his view of Prince Alexander of Hesse-Darmstadt, whom, he noted, was attending Villafranca in the service of the Hofburg. ${ }^{6}$ And there had been no mistaking the dejected tone in Wächter's telegram from Paris on the same day, which informed Wilhelm that "the peace is signed." Württemberg's wishes had been to have the conflict between France and Austria prolonged, in order to buy itself time to determine its position in the conflict, and in Germany itself. Villafranca meant that that luxury no longer existed, but Württemberg's hostility (or, at the very least, its desire to differentiate its political course from that of Austria) was palpable.

The second Würzburg Conference began on 30 July and concluded on 6 August. In that time, the Mittelstaaten arguably did more to further the cause of Third Germany than they had in all the decades since the Congress of Vienna. In particular, the attendees representatives from Württemberg, Bavaria, Saxony, Hanover, Baden, Hesse-Darmstadt and Hesse-Kassel - proposed that the Mittelstaaten, bound together by their political and geographic circumstances in between the great powers, as well as their 'pure' German heritage, were naturally united in military affairs. To that end, they voted that the Confederal army should not include any contingent or influence from either Austria or Prussia, but should instead be a body entirely independent and made up only of Mittel-and Kleinstaat contingents, and led by a commander-in-chief to be chosen from amongst the those states. At last, and seemingly by accident, the Mittelstaaten had resolved to reform themselves, and thus enter into a Third German coalition, using the template of the Confederal army corps as a pattern to follow. This consciously placed the Mittelstaaten in opposition to the influence of the great powers. Moreover, if the resolutions of the conference were enacted, the expanded military power of the Mittelstaaten would permit

\footnotetext{
${ }^{6}$ Ow to Hügel, Vienna, 12 July 1859. HStAS.E50/01 Bü.875.

7 Wächter to Hügel, Paris, No.1466, 12 July 1859. HStAS.E50/01 Bü.875.
} 
them to avoid a similar situation to what Bavaria and Württemberg faced in 1850 , when both were forced against their will to intervene in Hesse-Kassel. A Third German military bloc would also create the framework for a political body, which would permit the Mittelstaaten to respond to changing scenarios with greater vigour and rapidity. As such, the hesitance of 1859 could be avoided, if an opportunity similar to the Second Italian War of Independence presented itself again. Simply put, the Würzburg Conferences, while not consciously intended as such, were beginning to lay the groundwork for the formation of a Third German nation-state.

As the plans gained momentum, the representatives proposed to meet again in 1861 . In May they did so, again in Würzburg, although this time Baden was absent. Here, however, the states ran into practical, rather than theoretical problems. Sir John Ralph Milbanke, the British minister plenipotentiary to Munich, summarised the problems facing the Third Germanists. To Milbanke, "the only two likely Candidates for [the command of the Mittelstaaten army] are the King of Wurtemberg [sic.], who is 80 years of age, and Prince Charles of Bavaria, whose health would scarcely, I should think, permit him to risk the fatigues of active service in the field." In spite of the fact that the second Würzburg Conference had been a Saxon initiative, by the time of the third conference Bavaria and Württemberg had reasserted their authority as the leading states of the Third German project, as is demonstrated by their candidacies as leaders of a united army. This, the British minister felt, could inspire "the jeaulousies [sic.] of 1859 [to be] revived", suggesting that Milbanke believed that the preeminence of either or both of these states might act as a source of discord with the other Mittelstaaten; indeed, Baden's lack of involvement in the third conference suggested that Karlsruhe was becoming uneasy at the prospect of its old sparring partner, Munich, once more gaining the ascendency. ${ }^{9}$ Furthermore, though the

\footnotetext{
8 Sir John Ralph Milbanke to Lord John Russell, No.63, Munich, 28 May 1861, in British Envoys to Germany, Vol.IV, 426.

${ }^{9}$ Ibid., 427.
} 
Würzburg Conferences were intended to formulate a Mittelstaaten method of dealing amongst one another, at least some commentators were skeptical of Third Germany's ability to stand on its own. The British consul-general in Leipzig, Sir Joseph Crowe, warned Whitehall that the Würzburg Conference was intended to recreate the Confederation of the Rhine, and place it under French auspices. As evidence for this, he noted that HesseDarmstadt's foreign minister, Baron Reinhard von Dalwigk zu Lichtenfels, had travelled to Paris in April, and had not returned by May. ${ }^{10}$ Meanwhile, Milbanke dismissed the importance of the conference completely. "Nothing [...] worth relating has transpired", he wrote in his telegram to the Foreign Office, "and indications, that [the conference deliberations] are already beginning to lose some of the importance with which they were at first invested, are by no means wanting." 11 Indeed, the 1861 conference stalled on the question of army leadership, and the Mittelstaaten, which had begun negotiations so promisingly, now became mired in detail. Once more, Third Germany had stalled.

\section{Sovereignty and Reality.}

The Kingdom of Württemberg at the start of the 1860s is reminiscent of an underdog boxer, facing off against a heavyweight champion. It struggled valiantly, reeling from blow after blow but somehow keeping its feet, occasionally landing a punch of its own. It would be going too far to claim that the result was never in doubt. However, with each passing round the impression is one of inevitability. Ultimately, the challenger will fall. The question is not if - nor, perhaps, even when - but how. There was plenty to admire of this little, undervalued state. Its small army had been called to action on a handful of occasions, and had conducted itself well. Its king was genuinely loved by a population that enjoyed

\footnotetext{
${ }^{10}$ Dalwigk's visit to Paris was, in fact, personal and not official, but Crowe believed that Dalwigk was there to assure Napoleon III of southern Germany's favourable disposition towards an extended French influence in Germany. George John Robert Gordon to Russell, No.65, Stuttgart, 28 May 1861, in British Envoys to Germany, Vol.IV, 365-369.
}

${ }^{11}$ Milbanke to Russell, No.63, Munich, 28 May 1861, in British Envoys to Germany, Vol.IV, 426. 
and prided itself on its liberalism and enlightened constitutional governance. The crown had defended Württemberg's territorial interests and sovereignty, while leaving open the question of national unification. Its default position had always been to fall back on the kingdom's rights as an independent state, which was occasionally bolstered by its desire to fashion a Third German alliance of equal Mittelstaaten. However, entering the 1860s, independence was becoming increasingly untenable, and the Third German project continued to ensnare itself in problems of composition and leadership.

On other fronts, though, Württemberg began to make rapid progress. In particular, the economy, which had always been a major concern for the crown and state, enjoyed positive reforms. The nineteenth century had brought with it near-miraculous innovations in industry, the most vital of which was, undoubtedly, steam power. Steam engines provided energy for newly mechanised means of production, and steam boilers could propel locomotives, pulling wagons and carriages, much faster than previous transportation methods involving horses or barges on canals. This increase in production efficiency corresponded with the rise of a European consumer culture - a culture of appearances from which Württemberg was by no means immune. The population's newfound desire and need for clothing, dyes and other consumer goods was to be found in Stuttgart just as it was in London or Paris. ${ }^{12}$ Like these markets, Württemberg had its own manufacturing centres. Where England had Manchester to provide its textile needs, Württemberg had Heidenheim, a relatively small town located along the Brenz river. During the 1850s, Heidenheim, as the linchpin of the Württemberg cotton industry, experienced a manufacturing boom. This coincided with the development of inexpensive new looms,

\footnotetext{
12 Hans Medick, Weben und Überleben in Laichingen 1650-1900: Lokalgeschichte als Allgemeine Geschichte (Göttingen: Vandenhoeck \& Ruprecht, 1997), 380.
} 
both mechanised and hand-operated, by Gottlieb Meebold and Daniel Schwarz. ${ }^{13}$ At the beginning of the 1850s Württemberg's textile industry operated approximately 300 mechanised looms, of which forty percent were located in Heidenheim. By 1852, thanks to the inexpensive and mass-produced new looms of Meebold, Württemberg employed some 673 mechanical looms, 220 of which were used by the Heidenheim textile factories alone. ${ }^{14}$ By 1861, in Heidenheim proper and its administrative surrounding areas, some 1,711 people were employed among twenty-seven firms either producing textile goods or directly involved in the industry. 15

Heidenheim was just one example of Württemberg's sudden economic growth. The textile production capacity of the state was boosted by the mechanisation of even the cottage industries, which in turn caused them to grow; gradually, expanded public textile companies replaced small, inefficient hand-weaving and cloth-making artisans. In part, this resulted from government policy stipulating total freedom of commercial competition. This laissez-faire attitude towards Württemberg's key industries meant that the traditional artisan and journeyman workshops (the so-called Einzelmannbetriebe, or 'single-manenterprises') were forced by competition to modernise and expand or else risk economic extinction. ${ }^{16}$ In other industries, too, Württemberg began to benefit from the free-trade policies of the Zollverein. Lower import duties on raw materials meant that metalworks and machine factories were not only possible but thriving. The Esslingen Machine Factory

\footnotetext{
13 Looms were traditionally expensive, with a single-thread loom costing in excess of $120 \mathrm{fl}$. apiece. Schwarz's design, which allowed for two tracks of thread, could be sold for $55 \mathrm{fl}$. When Meebold adapted it for mass production, he was able to reduce the price further, to just $15 \mathrm{fl}$. This, coupled with the almost limitless supply of cotton available to Heidenheim Textilfabriken, led to an enormous boom in output and profits. Reiner Flik, Die Textilindustrie in Calw und Heidenheim 1750-1870 (Stuttgart: Franz Steiner Verlag, 1990), 177-178.

${ }^{14}$ Ibid., 182-183.

15 It is also important to note that, at this time, Heidenheim's population was not more than 4,000. Ibid., 377.

16 Private investment in the textile industry reached its zenith in the 1860 s, as the combination of a resurgent export market and the application of mechanised looms caused a resurgence in Heidenheim and the other Württemberg textile capitals. This is investigated in great detail in Gert Kollmer-von Oheimb-Loup, Innovation und Zollverein, 168-193. See also Gerlinde Runge, Die Volkspartei in Württemberg von 1848 bis 1871, 6.
} 
had been founded in 1846 but struggled to make any initial impact on the Württemberg economy; by 1861 it employed nearly 1,000 Württembergers as workers, and became the most important manufacturer of steam locomotives in southern Germany. ${ }^{17}$ In terms of the number of industrial workers, the factory was only beaten by the state iron works in Wasseralfingen, which employed some $1,200.18$ Steam engines in all industries became almost ubiquitous. By 1868 , the Heidenheim district contained some twenty-nine steam engines generating a maximum of 324 horsepower. This placed Heidenheim third on the list of mechanised districts in the kingdom; Stuttgart already had fifty-three machines generating 521 horsepower available as of 1861, and Heilbronn maintained thirty-one machines for a combined output of 486 horsepower. ${ }^{19}$ In all, by 1868 there were some 494 stationary steam engines generating power in Württemberg factories, and a measure of the expansion of the mechanised factory network can be seen in the fact that 355 of these steam engines were manufactured in Württemberg. ${ }^{20}$ Given the state's previous intractability on matters of industrial power production, the statistics suggest a revolutionary improvement in Württemberg's material and financial prospects.

Yet the figures masked underlying problems. While Heidenheim had grown in importance to the textile industry, this was largely the result of private capital and investment; its position at the centre of Württemberg's economic recovery was not reflected in government policy. Coal remained in short supply, which forced industrialists to look elsewhere for fuel. Heinrich Voelter, a paper magnate and representative of the Heidenheim district in the Landtag, argued during a sitting in 1857 that the Heidenheim industrialists had no need for coal as long as the prices for peat remained low. Voelter's aim

\footnotetext{
${ }^{17}$ In Württemberg itself, there were seventy-nine steam locomotives active on the railways in 1868. Of these, fiftyfive of them were built in Esslingen. Gert Kollmer-von Oheimb-Loup, Innovation und Zollverein, 281.

18 Gerlinde Runge, Die Volkspartei in Württemberg, 7.

${ }^{19}$ Reiner Flik, Die Textilindustrie in Calw und Heidenheim, 39-41.

${ }^{20}$ Gert Kollmer-von Oheimb-Loup, Innovation und Zollverein, 281.
} 
was to force the government into a form of price protectionism, guaranteeing that the price of peat would stay at affordable levels. But Voelter was disappointed by the Landtag's subsequent (but typical) inaction. It was, in fact, left to the factory owners themselves to form a cartel to cooperate to drive prices downwards. ${ }^{21}$ Even so, costs spiralled, and just four years later, the economist and politician Moriz Mohl reported to the Landtag that the yearly coal needs of the Heidenheim factories already exceeded 60,000 kilograms, and due to the increasing timber and peat costs, would balloon to over 100,000 kilograms.22 As a result of these problems of fuel supply, the seemingly impressive improvement in Württemberg's steam power output was, by comparison to other German states, embarrassingly minor. Württemberg factories were generally unimpressive. In Prussia’s main industrial centre, Essen, the Krupp Steel Works alone operated no less than 136 steam engines, generating 3,160 horsepower. This corresponded to well over twice as much power as that generated in Stuttgart, Heilbronn and Heidenheim combined.23

Heidenheim was ambitiously called "the Swabian Manchester" by the citizens of the state, but in actual fact it was quickly falling behind, and there seemed no way to improve the situation. Moriz Mohl's report to the Landtag had recommended that the government absorb the cost of importing the 100,000 kilograms that he expected would be required for the Heidenheim factories; his caveat was that this should only be approved once a rail line to Heidenheim had been constructed. In Prussia, France or Britain, the implications of such a statement would have been unthinkable; nonetheless, the fact remained that at the beginning of the 1860s the most important industrial centre in Württemberg was not

\footnotetext{
21 Albrecht Koberstädt, "Energieprobleme im Oberamt Heidenheim. Ein Beitrag zur Wirtschafts- und Sozialgeschichte der Region Ostalb” (Schwäbisch Hall: Ph.D. diss., 1980), passim; Reiner Flik, Die Textilindustrie in Calw und Heidenheim, 40-41.

22 Uwe Siedentop, Die Brenztalbahn (Heidenheim: Verlag Uwe Siedentop, 1984), 108-115.

23 Preussische Statistik, 8.Bd. (Berlin: Preussisches Königliches Statistisches Landesamt, 1865), 131.
} 
linked to the rail network, and connected to the rest of the state only by unpaved roads and barges along the Brenz.

If the economic situation was deteriorating, Württemberg's ability to stand as a military power in its own right was also crumbling. By 1854, the War Ministry had concluded that the Württembergisches Heer required rearmament and modernisation. The small-arms and artillery pieces that the army had traditionally relied upon were the same smooth-bore muskets and brass cannons that dated back to the Napoleonic Wars. However, in recent years, other states had begun to modernise their arsenals. By 1839, Dreyse's needle-guns had been successfully demonstrated at the Prussian proving grounds at Spandau, where they proved able to fire off fifty rounds in one test period, and achieved a rate of fire some five times faster than comparable weapons. ${ }^{24}$ The impressive development of the needle-gun, and its prodigious abilities, were not immediately apparent outside of Prussia, but elsewhere, rifled firearms were beginning to gain acceptance. Friedrich Engels was dismissive of the "comic opera efforts [...] and drunken carnival spirits" of the Badenese rebels who faced Prussian counterrevolutionary police actions in 1849 , but the "amateur soldiers" were armed with a wide range of rifled weapons, and their marksmanship caused the well-drilled Prussian army considerable headaches. ${ }^{25}$ In France, the new Minié rifles muzzleloaders with rifled barrels - enjoyed their own successful development. The Minié system was based on existing weaponry, while the needle-gun was a radical departure from traditional firearms. As a result, Minié-type weapons were soon adopted by most European countries, and they developed a fearsome reputation. The British version, the Enfield, would become famous in its own right, not least after it managed to account for some 15,000 Russian casualties at Inkerman in 1854, during a battle in which the Russian Army

\footnotetext{
${ }^{4}$ Sigurd Rabe, Das Zündnadelgewehr greift ein, 18.

25 Martin Kitchen, "Friedrich Engels' Theory of War", Military Affairs 41, 3 (October 1977), 120; Dennis E. Showalter, Railroads and Rifles, 165.
} 
had a vast advantage in artillery but only older, smoothbore muskets as infantry weapons. ${ }^{26}$ Inkerman was such a triumph of the modern rifle that it inspired the Prussian staff officer Helmuth von Molke to write a service journal article entitled "On the Influence of Arms on Combat Perfection"; in Moltke's view, the rifled bullets of the Enfields "simply could not miss."27 Moreover, in the hands of an expert sharpshooter, the Minié could outrange a Dreyse by as much as 300 paces. ${ }^{28}$ The Minié found many enthusiastic proponents. The Saxon firearms expert Julius Schön lauded Miniés as being "so-called precision weapons" because of their extraordinary ability to "force [the bullet] to follow its flight path."29 Engels felt that the Minié was superior to its Dreyse counterpart because it was simple to use and maintain; since many soldiers were "ill-trained militia", the complexity of a breechloader would merely underscore the average soldier's incompetence. ${ }^{30}$

It is to the credit of the Württemberg War Ministry that, in 1854, it chose to place a substantial order for rifles to replace its old smoothbores. It is also understandable that the ministry chose the Minié over the Dreyse. The Minié was patterned on familiar weapons, using common parts, and had fewer unfamiliar features. The army had, in fact, had the opportunity to test one of the Prussian needle-guns, and had come to the conclusion that the superior rate of fire of the weapon would just encourage overeager soldiers to fire off all their ammunition while well out of effective firing range, leaving them defenceless and at the mercy of their Minié-armed opponents, who could pick them off at range before

\footnotetext{
26 Geoffrey Wawro, "An 'Army of Pigs': The Technical, Social, and Political Bases of Austrian Shock Tactics, 1859-1866”, The Journal of Military History 59, 3 (July 1995), 411.

27 Karl Folliot-Crenneville, Die österreichische Nordarmee und ihr Führer in Jahre 1866 (Vienna: Wilhelm Braumüller, 1906), 33; Helmuth von Moltke, "De l'influence des armes perfectionées sur le combat", MilitärWochenblatt, 8 July 1865.

28 Dennis E. Showalter, Railroads and Rifles, 94.

29 Julius Schön, Das gezogene Infanterie-Gewehr: Kurze Darstellung der Waffensysteme der Neuzeit und ihrer Anwendung in den Armeen Europas (Dresden: C. Höckner, 1854), 39.

${ }^{30}$ Martin Kitchen, “Friedrich Engels' Theory of War”, 120.
} 
closing in and making short work of them with the bayonet. ${ }^{31}$ The Miniés adaptation to existing weaponry was also attractive since, like the rest of Württemberg's industrial sector, the armaments industry was in its infancy; the small Royal Württemberg Munitions Factory at Oberndorf would be responsible for manufacture, with assistance from the Ludwigsburg Arsenal. It was economically advantageous, therefore, to employ the Minié system..$^{32}$

In artillery, too, the army had already increased its firepower. Between 1817 and 1840 , the 18 guns of the army had increased threefold, divided into three batteries of horsedrawn artillery and four foot artillery batteries of eight guns apiece. ${ }^{33}$ However, none of these new weapons were rifled, and all were muzzleloaders made either from bronze or iron, in contrast with the new breech-loading rifled Krupp guns coming into service in Prussia, which were built from sturdy, lightweight crucible steel, and which had far greater effective range than anything then employed in Europe. ${ }^{34}$

That Württemberg rearmed with the Minié rifle would, in the fullness of time, be exposed as a mistake, but it is difficult to be critical of the decision. It was a modern weapon with a proven track record. The British Enfield carved out a legend at Inkerman by mowing down vast numbers of Russian soldiers, in a position that the British should have found untenable. The Austrian version of the Minié, the Lorenz, was far superior in range compared to other weapons of the time; in the hands of a competent marksman, the

\footnotetext{
31 Albert Pfister, Deutsche Zwietracht, Erinnerungen aus meiner Leutnantszeit (Stuttgart: J.G. Cotta, 1902), 36-37.

32 The French would also take advantage of this well into the $1850 \mathrm{~s}$; most of their infantry in the Crimean War was armed not with new rifles, but old muskets equipped with expanding Minié bullets. Dennis E. Showalter, Railroads and Rifles, 99.

33 In peacetime, one battery of foot artillery was kept in reserve, rather than in active service. Karl Pfaff, Geschichte des Militärwesens in Württemberg, 135.

34 Morton Borden, "Friedrich Engels on Rifled Cannon", Part 1, Military Affairs, 21, 2 (Summer 1957), 75-76; Morton Borden, "Friedrich Engels on Rifled Cannon”, Part 2, Military Affairs, 21, 4 (Winter 1957), 194; Prince Kraft Karl August Eduard Friedrich zu Hohenloe-Ingelfingen, Auszeichnungen aus meinen Leben, 1.Bd. (Berlin: 1897), 120-121.
} 
Lorenz had an effective firing range of some 900 metres. In 1849, when the Dreyse weapons had their first baptism of fire in the police action in Baden, not even the Prussian Army was convinced that Berlin had chosen correctly. At least one general, Karl Wilhelm von Willisen, expressed his feelings that a simpler, muzzle-loading rifle such as the type that would evolve into the Lorenz would be a much more durable, reliable and satisfactory weapon than the comparatively complex, fragile and unconventional needle-gun. ${ }^{35}$ As late as 1866, Austrian commanders were convinced that the Dreyse was a totally inferior weapon to the Lorenz. It is therefore no indictment on Stuttgart that a Minié-type rifle was preferred, even if the Dreyse would prove itself the better weapon by the time it was truly used as intended, in 1864 and 1866.

In any event, the Lorenz-equipped Württemberg infantry at least enjoyed rearmament to a modern standard. The same can neither be said of its artillery corps, nor of its logistics. The number of cannons in the army's arsenal had increased markedly since Friedrich's day, and with some sixty horse-drawn or foot artillery pieces in service, Württemberg's artillery corps was proportionately as large as most contemporary European armies. ${ }^{36}$ However, these guns - which, like their counterparts in the Austrian artillery, qualify for Engels' criticism of being "as clumsy a material as any in Europe" - were obsolete by the 1860 s, and would be no match for more advanced, steel-fashioned, rifled weapons such as Krupp's remarkable field guns. ${ }^{37}$ Even this weakness, however, paled in comparison to the problem of transportation and logistics.

\footnotetext{
35 Dennis E. Showalter, Railroads and Rifles, 94.

36 In 1868, the French Minister of War Adolphe Niel reported to the Chamber of Deputies in Paris that "everywhere else there are three pieces [of artillery] per 1,000 men"; Württemberg's army corresponded to this, and this contrasted favourably with the figures of the French Army, which (Niel claimed) had only two cannons per 1,000 men. Thanks to Wilhelm's reforms, Württemberg's position had become a reality by 1840 . By contrast, under Friedrich the Württembergisches Heer boasted only 1.25 guns per 1,000 soldiers. Le Moniteur Universel, 8 July 1868. HStAS.E50/12 Bü.143.
}

${ }^{37}$ Morton Borden, “Friedrich Engels on Rifled Cannon”, Part 2, 193. 
One contemporary commentator, reflecting on the development of Württemberg's railways, insisted that the railways were not simply vital for Germany's economy and continued competition in the world market, but "in war, as our strategists teach us, [the railway] is the last word." 38 It was Prussia that first saw the use of the railways in a military context. During the September exercises of the army in 1839 , a train carried soldiers of the Prussian Guard between Potsdam and Berlin. ${ }^{39}$ The Saxons and Bavarians soon followed suit. In Württemberg, however, any plans for a military application of a rail network were stymied by the characteristic unwillingness of the Landtag..$^{40}$ By 1850 , eight years after the plans had been drawn up for a north-south line connecting Heilbronn to Friedrichshafen via Stuttgart and Ulm, the line extended only as far as Ulm: merely 250 kilometres of track. By 1855 , just fifty-five kilometres more had been laid, although at last Württemberg's state railway had reached Lake Constance. ${ }^{41}$

In part, the continued glacial development of the railways was due to the fact that the Landtag saw trains purely in economic terms. Railways were tools of industry, and the intransigence of the agriculturally-minded parliament once more conspired to cause difficulties. As an instrument of modern warfare, however, the advantages of the rail system were poorly understood. This contrasted markedly with Baden, in which the government, recognising the defensive advantage of an extensive rail network, instituted a statewide broad gauge track rather than the standard gauge employed by Prussia, Hanover and Austria. In the event of a national emergency, the Badenese had the ability to shuttle their troops rapidly along any point of their network, which ran from Strasbourg, along the

\footnotetext{
38 Arthur Mülberger, Die Eisenbahnreform in Württemberg, 90-91.

39 Dennis E. Showalter, Railroads and Rifles, 27.

40 Allan Mitchell, The Great Train Race, 46.

${ }^{41}$ Kiesewetter cites the 1855 figure at closer to 280 kilometres - an extension of just 30 kilometres. Also, the line to Lake Constance did not end at Friedrichshafen, as the Württemberg government had hoped. Rather, on the insistence of the Bavarian government, the Constance terminus was located at Lindau. Hubert Kiesewetter, Industrialisierung und Landwirtschaft: Sachsens Stellung im regionalen Industrialisierungsprozess Deutschlands im 19. Jahrhundert (Cologne: Böhlau, 1988), 610; Arthur Mülberger, Die Eisenbahnreform in Württemberg, 3-4.
} 
French border, to Karlsruhe, Mannheim, and Basel, on the Swiss border. Any invader would have to disembark at the Badenese border, and either march the rest of the way, or else capture and use Badenese rail transport. 42 The non-standard gauge was briefly considered by the Württemberg War Ministry, but its recommendation for an isolated and unique gauge, linked only with Baden to form a sort of defensive rail network, was overruled by the "businessmen and industrialists who preferred the concrete advantages of standard gauge to security against a possible future invasion." ${ }^{3}$ Thus, the application of the railways as a military venture was blocked by industrialists who wished to use the railways for the development of the industrialised economy. This, in turn, was blocked by the Landtag, which sought to protect and promote its vested interests in agriculture, not industry. If ever the difficulties of Württemberg state politics could be encapsulated in one illustrative example, surely the debacle of the railways is just that.

The stunted growth of the Württemberg rail network meant that its potential as a mode of military transportation was minimal at best. Its neighbours, on the other hand, jumped at the opportunity to incorporate the new technology into their war plans, be they offensive or defensive. In 1844 the Saxon army drew up plans for the deployment of "a brigade of 4,800 men [who] could be transported via rail with the use of just twelve locomotives and 120 carriages." 44 This could be accomplished through the use of the great

\footnotetext{
42 Abigail Green, Fatherlands, 233; Allan Mitchell, The Great Train Race, 47; Dennis E. Showalter, Railroads and Rifles, 33.

43 Captain Karl Eduard Pönitz, the Saxon soldier and military writer, and great proponent of the railways, also suggested eloquently and forcefully in his monograph Die Vertheidiung von Süddeutschland that the states such as Württemberg and Hesse-Darmstadt would in fact benefit from the advantages of collective security that would arise from a standardised German network. In practice, this was not the case, particularly for Württemberg; instead, for many years the Württemberg network was all but isolated from the rest of Germany by dint of Bavaria's desire to circumvent the kingdom's lines for reasons of commerce. Even on the eve of the Reichsgründung in 1871, Württemberg was essentially on its own. Dennis E. Showalter, Railroads and Rifles, 34; Karl Eduard Pönitz, Die Vertheidigung von Süddeutschland gegen die Franzosen, mit Zuziehung der Eisenbahnen, unter Berücksichtigung der verschiedenen Spurweiten (Tübingen: J.G. Cotta, 1844), passim.

${ }_{44}$ Karl Eduard Pönitz, Die Eisenbahnen und ibre Benutzung aus militärische Operazionslinien (Adorf: VerlagsBureau, 1853), 42-48; Klaus-Jürgen Bremm, Von der Chaussee zur Schiene: Militärstrategie und Eisenbahnen in Preussen von 1833 bis zum Feldzug von 1866 (Munich: Oldenbourg Wissenschaftsverlag, 2005), 137.
} 
Dresden to Leipzig main line, which permitted rapid and efficient transportation of such a large amount of men and materiel between Saxony's two largest cities. By comparison, the newest addition to the Württemberg rail network was a paltry four-kilometre stretch of track from Cannstatt to Untertürkheim, a short and militarily useless link that terminated five kilometres outside of Stuttgart. ${ }^{45}$

\section{The Necessity of Germany and the Death Throes of Württemberg Autonomy.}

The defence of Württemberg's particular interests was the "default" position of the government and the crown from the end of the Napoleonic Wars. At no juncture had Stuttgart attempted to barter away its competence over its own territories and people. Rather, it had tried at every turn to avoid being subsumed by the selfish interests of the great powers, while at the same time claiming a leading role in the national projects that it championed. In this way, Wilhelm, like Max II, may have been a German patriot, but he saw his first duty to be to his state. Thus, if the formation of Germany were to place Württemberg at a disadvantage, then Wilhelm and his government would declare themselves for Württemberg, at the expense of Germany. ${ }^{46}$

By the 1860 s, though, independence was no more than an illusion. In spite of the promising statistics, the economy was in tatters. Unable to compete either locally or internationally, it had begun a slow death spiral that could only conceivably be arrested by some sort of federal intervention and assistance. Militarily, though the army had grown, and though it had rearmed, it still could not be expected to offer anything but token resistance to possible threats. Only belatedly did Stuttgart recognise its need to modernise,

\footnotetext{
45 Arthur Mülberger, Die Eisenbahnreform in Württemberg, 3.

46 This view was also expressed by Gordon in a telegram to Russell, in which he claimed that "the thorough and distinctive German local feeling" of particularism would, in his opinion, always trump any pan-German project. "The appearance of some first rate leading mind and talent in Germany might possibly effect the unity of his country", the minister concluded, "but such a man is still a Desideratum in the Fatherland." Gordon to Russell, No.21, Karlsruhe, 16 February 1862, in British Envoys to Germany, Vol.IV, 371-375. See also Manfred Hanisch, Für Fürst und Vaterland, 87-88.
} 
and a new and intense rail-building phase was begun at the start of the decade. However, even this was conducted haphazardly, with little or no attention given to either financial or military expedience. As Arthur Mülberger noted acerbically, "there were those in the Chamber who would have liked nothing more than to have built a track to the moon." But Württemberg's future lay not on the moon but in Germany, and here it continued to lag behind. ${ }^{47}$ The Landtag's rail policies thus continued to be uneven and poorly planned, and once more, the state's individual position in Germany suffered.

By 1860 , the ageing King Wilhelm was beginning to suffer a crisis of resolve. For so long he had defended Württemberg's territorial interests, while leaving open the option of national unification. Württemberg had not supported the proposal of the National Assembly in 1848 to offer Prussia’s Friedrich Wilhelm IV the imperial crown of Germany precisely because Württemberg feared Germany would become the secondary interest. Much like Metternich had used the German Confederation as Austria's plaything, Wilhelm worried that Friedrich Wilhelm would do the same. Austria had not enjoyed any surge in popularity, either, and Third Germany had been mooted seriously, but often found wanting. The default position of Stuttgart had therefore always been to fall back on the kingdom's rights as a sovereign state. Now, the situation had changed again. In his twilight years Wilhelm was perceptive as ever. German unification, he reasoned, was now a fait accompli. Württemberg's independence could not last forever, and the same could be said of many (if not all) of the other Mittelstaaten. What had not yet been decided, though, was the form this unification would take. In the first two months of 1860, two new proposals were put forward by royal houses of the south. One, from Wilhelm himself, nearly caused a mutiny among his ministers. The other, originating in the tiny Principality of Saxe-Meiningen, would prove significantly more popular but nonetheless short-lived.

\footnotetext{
${ }^{47}$ Allan Mitchell, The Great Train Race, 46; Arthur Mülberger, Die Eisenbahnreform in Württemberg, 16.
} 
Approaching eighty years old, King Wilhelm was in 1860 just as pragmatic a ruler as he had been for over forty years. In spite of the precocious beginnings of his reign, he had proven time and again that he had learnt the political and social lessons of his era, and had acted accordingly. Yet he had seen his every attempt to foster a closer cooperation between the Mittelstaaten fail due to petty interstate disputes and the difficulties of creating a workable federation of a handful of generally equal states, each of which aspired to lead Third Germany. He had also seen Prussia emerge from isolation to lead police actions in Baden and to defend the integrity of Hesse-Kassel. Regardless of the legitimacy of any of these actions, it should also be recognised that Prussia, unlike Austria, had not threatened to drag the rest of Germany into war with any other European power between 1815 and 1860.48 On the other hand, Austrian adventurism in the Balkans and eastern Europe antagonised the Russians and the Ottoman Empire, and the nature of its policies in Italy and southwestern Europe had led to conflict, both diplomatic and military, with France on several occasions.

For reasons not entirely clear but most likely related to the war between Napoleon III and Franz Joseph a year earlier, in 1860 Wilhelm came to the conclusion that an attack by France, with the intent of capturing the Rhine, was imminent. ${ }^{49}$ With the spectre of war looming once again, with Austria typically unreliable and with Third Germany a seemingly lost cause, Wilhelm's one option was to turn to Prussia. His rationale, expressed through his state minister, Karl Eugen von Hügel, to Prussia's ambassador in Stuttgart, Gustav von der Schulenburg, was that the VIII Corps of the confederal army could not resist a French invasion without Prussian assistance. Wilhelm was therefore suggesting that his country required the direct military intervention of Prussia. This, in turn, suggested that Wilhelm

\footnotetext{
48 On this note, he butted heads more than once with his Bavarian counterparts, who saw Prussia as the greater of the two evils. Manfred Hanisch, Für Fürst und Vaterland, 153.

49 This belief persisted, in spite of Napoleon's personal assurances to Wilhelm that France had no intention of doing so. Wilhelm had Hügel send his compliments to the emperor, but continued to worry. Paul Sauer, Reformer auf dem Königsthron, 557-558.
} 
was willing to surrender some claim to military sovereignty, and instead fall under the auspices of Berlin, providing this guaranteed the security of Württemberg against any French aggression.

Wilhelm's approach to the Prussians was an unprecedented volte-face. Though his government had negotiated with the Prussians for protection three decades earlier under similar circumstances, at least then Stuttgart had acted in conjunction with its Mittelstaaten neighbours. This was not the case now, and the suddenness of the appeal rankled many in Wilhelm's own government. In particular, Hügel himself, who had extended Wilhelm's suggestion to Schulenburg in the first place, now disavowed any association with it, while Miller, the minister of war, decried what he saw as an unnecessary, unwelcome and unpatriotic dilution of Württemberg's military sovereignty. But it was the response of Württemberg's neighbours that is most telling. The Saxon minister-president, Beust, reacted angrily, insisting that Württemberg had no right to unilaterally change its policy to one so friendly to Prussia. Beust, and his counterpart in Munich, Baron Karl von Schrenck, saw the German policies of the south German states as being collaborative. ${ }^{50}$ It was therefore, to them, unconscionable that the Württemberg crown was willing to act independently of a concerted south German (or Third German) initiative.

Within a month, Third Germany was once more on the cards. Recognising the public fear of a French attack, Duke Bernhard of Saxe-Meiningen presented his proposal for a comprehensive Third German programme. Bernhard's Germany involved the formation of a central authority, made up of Austria, Prussia, and representatives of Bavaria, Saxony, Württemberg and Hanover. This body would regulate Germany's foreign policy and military affairs, while a parliament, based on the existing Diet, would debate policy. Militarily, the various corps of the confederal army would be reorganised, such that Prussia and Austria would maintain their own armies, and those of the Mittelstaaten and smaller

50 Ibid., 558. 
states would be unified into a new Third German army. ${ }^{51}$ Beust greeted Bernhard's proposal with some enthusiasm. Even Wilhelm, perhaps reeling from the criticism of his suggested Prussian rapprochement, initially found the plan appealing; somewhat surprisingly, Vienna did not immediately oppose the suggested reforms..$^{52}$

Once more, however, this new Third German model collapsed under the weight of its own illogic. In spite of Wilhelm's positive response to Bernhard's ideas for reform, it became apparent to him that the driving force behind them was, in fact, Saxony's Beust. It concerned the Württemberg king that Saxony was manoeuvring into a position of preeminence; after all, previous attempts to do so by Bavaria and Württemberg itself had been key to the failures of previous Third German initiatives. This had been one of the greatest problems of the Mittelstaaten-based German nation-state: how could several nominally equal (or roughly equal) states enter into a coalition that would benefit them all and not permit the 'lesser' of them to be suborned to the 'greater'? This, after all, was the objection that the Mittelstaaten raised to Austrian or Prussian leadership, but what was there to stop Bavaria or Saxony, in particular, from acting as the de facto Austria in a smaller confederation? And, if such a problem could be avoided, how would such a coalition be governed? The Bernhard-Beust plan in fact added to the conundrum, with Beust insisting that all German states (except Austria and Prussia) should belong to a Third German bloc in a reconstituted confederal authority. With these smaller, weaker states included, any sense of statist equality was essentially impossible.

Wilhelm's suspicion of Saxony's intentions was probably well founded, but the proposal did little but rehash existing conceptual difficulties. In any case, the immediate stimulus for the renewed interest in Third Germany, being the fear of a new French war, was soon extinguished when, in July, Napoleon III travelled to Baden-Baden to meet with the

\footnotetext{
51 Ibid., 559.

52 Walther Peter Fuchs, Die deutschen Mittelstaaten und die Bundesreform 1853-1860 (Berlin: Ebering, 1934), 177-180.
} 
Prussian king and the other German heads of state. The fear of a French invasion died away, and with it, much of the immediate enthusiasm for Third Germany. ${ }^{53}$

\section{Competing Models: The Nationalverein and Pro-Prussian Sympathies.}

In the years preceding the 1848 revolutions, newsmen and liberal commentators such as Siebenpfeiffer, Wirth and Schulz had all extolled the virtues of Third Germany and the Mittelstaaten bloc. Given the political realities of those times, it is surprising that this was seen as a workable model of unification. By the 1860 s, the Third Germanists should have had no excuses. Their initiatives had always started promisingly, but the myriad irreconcilable difficulties they faced had doomed every attempt. Even the very form of Third Germany was unclear. Lindner's Manuskript aus Süd-Deutschland of 1821 had proposed that every German state barring Austria and Prussia should become members of the new German power. In Siebenpfeiffer's era, the unquestioned members of such a Bund were Bavaria, Württemberg and Baden, with Hesse-Darmstadt a likely partner. Conversely, the plans put forward by Duke Bernhard and championed by Beust mentioned neither Baden nor Hesse-Darmstadt as members of the so-called central authority government. Instead, Saxony and Hanover, neither of which had figured in most of the Third German plans until this point, would supersede them. In none of these models could the proponents answer the most fundamental questions of the existence of a competing third German power between Austria and Prussia. What would be the distribution of power? Would there be a head of state? If so, would the head of state be chosen by election, and if that were the case, what would the electoral franchise constitute? Presumably, the dynasties would remain; the House of Württemberg would still head the Kingdom of Württemberg, just as the Kingdom of Bavaria would keep its House of Wittelsbach. But what role would the king play in governance? Would the constituent states of Third Germany be permitted to

\footnotetext{
${ }^{53}$ Heinrich Ritter von Srbik, Deutsche Einheit, 3.Bd., 314.
} 
forge their own policies according to their individual state interests? Would legislation be controlled by a central power? Or, as Bernhard had suggested, would Third Germany be stripped of foreign and war policy, which would then be administered by negotiation and agreement between Third Germany, Prussia and Austria?

There were, quite simply, too many questions, both unanswered and unable to be answered. Yet even after the failure of the Bernhard-Beust proposition, Third Germany continued to gather supporters. The explanation lies not in Third Germany's merits, but in what it was not: it was not to be dominated by either Austria or Prussia, both ethnically and politically suspect states mistrusted by most (if not all) the Mittelstaaten.

Perhaps as a result of Third Germany's continuing shortfalls, yet recognising as Wilhelm did the inevitability of Germany, Württemberg liberal-nationalists began to return to the dualist model of unification. In particular, and largely following the personal opinions of the king, the sentiments of the politically active were better disposed towards Prussia than Austria. The emergence of the Nationalverein, a party-type organisation devoted to fostering a Prussian-led German solution, stands as eloquent evidence to the fact. The Nationalverein, or "National Union", appeared in the latter 1850s as a genuine Germany-wide movement that supported rapid, liberal unification under Prussian leadership. For all its Prussian sympathies, however, it was not an initiative of the Prussian government or ministries - indeed, the British believed it to be a "Republican Unitarian association for Germany", and republicanism was certainly not on Berlin's official agenda. ${ }^{54}$ Only two of the Nationalverein's leading members were Prussian parliamentarians: Hans Victor von Unruh and Moritz Veit. Neither of them held any official position in the Prussian power structure, and both had been relegated to their state's political wilderness

${ }^{54}$ Gordon to Russell, No.127, Stuttgart, 30 August 1860. FO 82/95. 
after the failures of 1848 and 1849.55 Of the other leaders of the Nationalverein, all were citizens of the Mittel- or Kleinstaaten. Bennigsen, the Hanoverian politician, is perhaps the best known, and roughly half were career politicians: the Bavarian deputy Brater took his place alongside the vice-president of the Weimar Landtag, Fries, along with the Wiesbaden politician Courde, and the prominent Stuttgart liberal, August Reyscher. The other half of the leading members of the Union were, if not 'ordinary' citizens, certainly men more representative of the various electorates of Germany, rather than the elite status quo. There was, for example, the Darmstadt advocate Metz, alongside Riesser, a lawyer from Hamburg, and Müller, a notary from Frankfurt am Main. Franz Hermann Schulze-Delitzsch, the economist and pioneer of credit unionism, was as important to the movement as the Leipzig bookstore proprietor and publisher, Mayer. ${ }^{56}$

To begin with, the Nationalverein struggled to gain political headway in Württemberg. This was mostly due to the fact that its first conferences were held in the northern German states, and therefore left the indelible impression that it represented Prussian or northern interests, at the expense of the south. This was a belief that its leading members soon attempted to remedy. An "Assembly of patriotic men" was organised in Esslingen in February 1861, and some 600 people attended in support of the Nationalverein, though membership grew by just 140 , to a total of 400 . The popularity of the rally was encouraging; the results of the membership drive were not. Following this, Reyscher requested that there be another assembly organised somewhere in the south, to cement the Nationalverein and its national political program in the southern consciousness. If this did not happen, he warned Bennigsen, "our objective [of national unity] will one

\footnotetext{
55 Unruh maintained some ties to the Prussian government through the auspices of the liberal historian and parliamentarian Maximilian Duncker, but the relationship was often strained due to Unruh's republican sentiments. Andreas Biefang, Politisches Bürgertum in Deutschland 1857-1868. Nationale Organisationen und Eliten (Düsseldorf: Droste, 1994), 70.

56 Constitutionelle Zeitung, Nr.165, 14 June 1859. HStAS.E50/01 Bü.877.
} 
again fall asleep here or will take on another form." 57 Bennigsen agreed, and more Nationalverein rallies followed in the southern states in the coming years. Thereafter, support for the Nationalverein increased. By 1864, the Württemberg branch had a membership of 600 people. This made the Nationalverein one of the largest popular political organisations in the state, and the fact that the membership had increased by fifty percent in three years demonstrates the growing appeal of Kleindeutschland in a state that had typically followed its own regionalist path. But the distribution of the membership was uneven. As the host town of many of the southern rallies, the industrial town of Esslingen was home to some 237 of the Verein's members. By comparison, the centre of Württemberg politics, Stuttgart, had only sixty-two members from a population of almost 30,000. In Tübingen, the traditional home of Württemberg liberal radicalism and Third German sentiment, just twenty-three residents had signed up to Bennigsen's program. ${ }^{58}$

What was truly remarkable about the Nationalverein, however, was not its membership base, but the fact that it was a clear breach of the Karlsbad Decrees. Yet it was not forcibly disbanded, as those decrees prescribed. The organisation had been at the centre of discussion at the Fifteenth Confederal Police Conference in Stuttgart, held between 6 and 8 August 1860, but the delegates had decided not to censure Bennigsen and his liberals. This decision was supported most notably by the Prussian delegation, whose government opposed the republican undertones of the orgaisation but had no objection to its amicable policies. This apparently unlawful position was justified with the suggestion that repression of the movement would "martyrise" its leaders. This argument was supported by at least two south German representatives. Both the Badenese police minister Carl Burger and his Württemberg counterpart Emil Majer saw the Nationalverein as no

\footnotetext{
57 Gerlinde Runge, Die Volkspartei in Württemberg, 16.

58 Ibid., 23.
} 
great threat, and argued that its suppression was unnecessary. 59 Though Württemberg was typically lenient when dealing with liberal or nationalist movements, this was a contentious position for Majer to take, given that it constituted a distinct breach of the statutes and legislative power of the German Confederation. However, given Wilhelm's political manoeuvres earlier in the year, perhaps this can be seen as another attempt at closer cooperation between Stuttgart and Berlin. Or, just as likely, perhaps Stuttgart's rejection of confederal law was a reflection of the growing discontent with the inadequacies of the Confederation as a legislative body.

Whatever the true meaning of Majer's support of the Nationalverein at the police conference, it was in keeping with Württemberg's softening attitude towards Prussia and its rank frustration with the German state of affairs. The position was also a challenge to Austria's longstanding hold on German policy, and indeed, Austria (through its faithful proxies in Hanover and Saxony) protested the decision to leave the Nationalverein intact, for how could it not? If successful, the Verein would call for unity of Germany under Prussia, with Austria isolated from Germany. This conflicted with the Austrian policy of maintaining a German status quo, and in particular, maintaining its own guidance over a loose (but not united) Germany.

The Nationalverein was hardly the only national organisation that appeared in Württemberg in the 1860 s. Nor was it even the largest or most influential. In 1862, the Reformverein, which was sympathetic to Austrian stewardship and promoted unitarian

\footnotetext{
59 Burger and Majer were not the only ones to argue that the Nationalverein was an irrelevance. The British also took a dim view of it. Gordon argued that south German governments would resist the Nationalverein if it became a genuine political force, because its platform "would only be a very short and easy step towards a Borussification of Germany and it is most natural therefore, that it should be looked upon with great apprehension [...] by the Sovereigns, Governments, and even by a considerable part, perhaps the majority of the populations of the numerous petty German States, whose independence, nay whose very existence, (I speak of the Dynasties) is thus directly menaced." But this would not eventuate, he assured Russell, because "it is all talk and nothing else; no action of any sort anywhere follows from it." Gordon to Russell, No.17, Stuttgart, 11 February 1862, in British Envoys to Germany, Vol.IV, 369; Gordon to Russell, No.21, Karlsruhe, 16 February 1862, in in British Envoys to Germany, Vol.IV, 371; Wolfram Siemann, "Deutschlands Ruhe, Sicherheit und Ordnung", 300-301.
} 
reform through the existing German Confederation, was founded in Stuttgart by (among others) the former particularist Moritz Mohl and Julius Fröbel, who had barely escaped an Austrian firing squad in 1848. Within a month of its foundation, the Reformverein had some 900 members in Württemberg alone.60 But the Reformverein was a rather different organisation to the Nationalverein. Firstly, its influence only extended to Württemberg and Bavaria, and close to its entire membership came from these two states. Secondly, it did not enjoy any support of the Austrian government. The Nationalverein was not an official project of Berlin, but Prussia was hardly averse to the friendliness of the kleindeutsch union. In any case, Mohl and Fröbel's leadership of the movement was conditional rather than devotional; they were reacting out of the perceived failure of the Third German experiment, not out of a genuine conviction in the goodness of Austrian federal power. ${ }^{61}$ Finally, while the Reformverein was advocating reform within the Confederation, while the Nationalverein sought to dismantle the Confederation. Its radicalism had brought it to the attention of the Confederal Police Conference. The failure of the delegates at that conference to censure or ban the Nationalverein demonstrated that Württemberg had finally, officially and publicly broken with its powerful southern neighbour, where previously it had only been able to entertain such fantasies without implementing them. Suddenly, in the most unlikely of fashions, the kingdom had set itself a new political direction.

\section{The Death of King Wilhelm and the Rise of Baron von Varnbüler.}

Wilhelm of Württemberg was a tireless, assiduous, conscientious king. But he was no longer the energetic young crown prince who had annoyed Johann of Austria, nor the wise but lively middle-aged monarch who celebrated his twenty-fifth jubilee with tens of thousands

${ }^{60}$ Gerlinde Runge, Die Volkspartei in Wirttemberg, 23-24.

${ }^{61}$ Willy Real, Der Deutsche Reformverein. Großdeutsche Stimmen und Kräfte zwischen Villafranca und Königgrätz (Lübeck: Matthiesen, 1966), passim. 
of his subjects in the forecourt of the Neues $S c h l o \beta$. Wilhelm had invested himself in all questions of the state, often to the exasperation of ministers like Miller and Hügel, but to the admiration of his people. By Autumn 1863, however, Wilhelm began to appear more and more lethargic. He sequestered himself away in his palaces, with little contact with his family or the outside world. He received few guests, although he kept himself occupied with matters of state through the attendance of his few aides. Aside from his servants, his two most frequent visitors were his personal physician, and his confidante, the former Munich actress Amalie von Stubenrauch, with whom he had enjoyed a fulfilling platonic relationship of more than forty years. ${ }^{62}$

In spite of his failing health, Wilhelm still attempted to influence and direct policy, though his opinions seem to have become rather more confused. In the Staats-Anzeiger of 24 January 1864, Wilhelm complained of the "embarrassing" state of affairs in Germany, and insisted that Prussia and Austria must come to an agreement to allow for the continuation of the German Confederation. ${ }^{63}$ Less than a month later, he roused himself to attend a two-day conference of Mittelstaaten leaders in Stuttgart, to discuss the response of the German Confederation to the Austro-Prussian invasion of the Danish territories of Schleswig and Holstein, in the far north of Germany. During this conference, Wilhelm insisted that no Württemberg troops would be sent north to assist either side, and the best result would be the integration of the two provinces into Prussia. ${ }^{64}$ Wilhelm's opinion had once more shifted to the idea of greater Prussian involvement in Germany, which seems at odds with his call in January for equality between the German great powers. Whether his wits were failing him is unclear, but it is more likely that he was simply rolling with public sentiment, leaning to whichever side he believed the weight of opinion was favouring, a

\footnotetext{
62 Paul Sauer, Reformer auf dem Königsthron, 570-571.

63 Staats-Anzeiger für Württemberg, 24 January 1864.

64 Paul Sauer, Reformer auf dem Königsthron, 570.
} 
tactic he had followed with great success throughout his reign. His political nous continued to gain him admirers. The Prussian minister-president, Otto von Bismarck, praised him as "the clever old gentleman", while on 1 March 1864, the Silesian town of Lübin, where the Württemberg king had been born in 1781, made him an honorary citizen. But the "clever old gentleman" had reached the end of his life. On 23 June 1864 he visited the stud at Weil, on the banks of the Neckar approximately ten kilometres southeast of Stuttgart. In a melancholy mood, he told his host, Count Taubenheim, that it pained him to know that he would be forced to leave a country so beautiful.65 Two days later, Wilhelm passed away, at the age of eighty-two, at the Rosenstein Palace in Cannstatt. He was interred at the mausoleum he had commissioned as the tomb for his wife Catharina, on the hill known as the Württemberg, after which his family and state had derived their names.

Wilhelm's death robbed Württemberg of arguably the most astute and able monarch in Germany. His successor, Crown Prince Karl, lacked the same moral certainty and political acumen of his father, and he was immediately unwilling (or unable) to assume the dominant south German mantle that Wilhelm had held on and off for almost half a century. Karl was uncomfortable with the pomp and circumstance that came with the role of king. Conversely, he did not convey the discreet and dignified figure that Wilhelm had for so many years. It was openly known that his wife, Grand Duchess Olga of Russia, wanted children, but Karl was apparently unable to oblige her. He had also been sexually indiscreet in his late teens and early twenties, having contracted gonorrhoea at least twice - a fact that was known at least to his cabinet of ministers, as well as his friends, and was likely an open secret among the general population. ${ }^{66}$ Another of Karl's "vices", his

\footnotetext{
65 Hans Gerber, "König Wilhelm I. von Württemberg als Bauherr und Regent - Zum 150. Todestag des Hofbaumeisters Giovanni Salucci”, Schwäbische Heimat 46, 3 (1995), 242.

66 Dr. Berthold von Fetzer, “Geschichte der Krankheit der verewigten Königs Karl Majestät”, 18 October 1884. HStAS.G313 Bü.12.
} 
extroverted homosexuality, or at least bisexuality, was more public, but did not cause him undue public difficulties until after 1871.67

More pertinently, Karl had little experience, and had shown little interest, in state affairs. Wilhelm had often complained about his son's inadequacies, and Olga's lady in waiting, Eveline von Massenbach, wrote scathingly of Karl and Olga's vanity, and the superficial duties of the crown prince and princess. ${ }^{68}$ Given his lack of political substance, it is perhaps to Karl's credit that his first act as king was a decree on 1 July, to increase the powers of his ministers, allowing them to effectively run the country more in the modern constitutional-democratic sense, rather than relying on monarchical direction.

The change in the Württemberg monarchy was not the only significant political change that would affect the state, though it is, perhaps, one of the great enabling moments of that state's history. Wilhelm had been a strong king who allowed his ministers some leeway, and operated within the bounds of the constitution. Karl was weaker, less able, and consequently the vacuum at the head of the state would have to be filled by a more astute state minister than the steady but subordinate Hügel, the ineffectual Linden, or the disastrous Römer. On 21 September 1864, in arguably the most important decision of his regency, Karl appointed the fifty-five year-old Karl von Varnbüler as his foreign minister effectively, the de facto position of head of government.

Varnbüler was a unique figure in Württemberg politics. His pan-German experience was unparalleled among the Landtag deputies. His nationalist credentials were, as a result, equally impressive. While Römer and his liberal colleagues had debated to a standstill with Gagern and his ilk in St. Paul's during the National Assembly of 1848 and 1849, Varnbüler

\footnotetext{
${ }^{67}$ Wilhelm had referred to his son's "terrible vice" as early as 1855 to the popular politician, Varnbüler. Varnbüler did not ask the king to clarify what this "terrible vice" was, and came to the (mistaken) conclusion that Karl indulged in habitual masturbation, which (he noted) could be resolved with a simple medical procedure. Conversation between King Wilhelm I. von Württemberg and Karl von Varnbüler. HStAS.P10 Nr.847.

${ }^{68}$ Eveline von Massenbach, Das Tagebuch der Baronin Eveline von Massenbach, Hofdame der Königin Olga von Württemberg (Stuttgart: Kohlhammer, 1987), 113.
} 
was a sitting member of the Select Committee of the Congress of Representatives of the Agricultural Unions of Germany. As the intellectuals tried and failed to define the high theory of German nationhood, Varnbüler's committee hammered out policies regarding common currency, weights, measures, taxes, patents and immigration - in short, practical considerations should Germany ever unite. ${ }^{69}$ He had spent time in Vienna, running the factory left to him by his father-in-law, and he was not unfriendly to Austria; many contemporaries referred to him as an Ultraösterreichischer — an "Ultra-Austrian."70

However, he had not neglected ties elsewhere. His third daughter Sophie married the Prussian officer Nikolaus von Below in 1862, and his second daughter, Hildegard, married her father's close friend, the Württemberg ambassador to St. Petersburg Baron Karl von Spitzemberg, in 1864. Through Spitzemberg, Varnbüler had been introduced to an up-andcoming junior Prussian Foreign Ministry diplomat, Otto von Bismarck, in 1859, and after Bismarck was elevated to the role of minister-president in 1862, Varnbüler and Hildegard visited him and his wife Johanna at their residence at Wilhelmstraße 76. Hildegard noted that the atmosphere at the Bismarcks' was "natural and refined", and that her father was comfortable enough in the presence of Bismarck to entertain long and "deeply involved" discussions on matters of politics. ${ }^{71}$ It was only natural, it seemed, that when Hildegard married Ambassador Spitzemberg, the couple would buy a house next door to the Bismarcks. ${ }^{72}$

Bismarck's ascent to the apex of the Prussian civil political hierarchy altered much of the course of German nationalism. It is, perhaps, going too far to suggest that, unlike his predecessors, Bismarck had a plan for Germany from the outset. It is true, though, that for

\footnotetext{
69 Geschäftsbericht des engern Ausschusses des Congresses der Abgeordneten landwirthschaftlicher Vereine Deutschlands, Frankfurt am Main, 30 April 1849. HStAS.P10 Bü.722.

${ }^{70}$ Fritz Hellwag, Varnbüler und die deutsche Frage 1864-1866, 4.

${ }^{71}$ Hildegard von Spitzemberg, Tagebuch, 49-50.

72 This, despite the fact that Spitzemberg would not become ambassador to Berlin until 1866.
} 
the first time in several decades, Prussia had a minister-president who had a clear idea of Prussia's position within Germany. Like his southern counterparts, Bismarck was a state particularist first and foremost. The German Question was still open as far as he was concerned, but never in question was his commitment to following a political course that (he believed) would benefit Prussia. A key point of this was a belief that Austria and Prussia could not coexist in the same political body; as competing great powers, one would eventually triumph over the other. Bismarck was determined for that victor to be Prussia, but he was also aware that the moment for this to occur had to be carefully selected and prepared for. In 1850, when Prussia had been brought to the negotiating table at Olmütz, Bismarck - then a junior member in the Prussian Landtag — had defended the resulting agreement. To the parliament he declared that "the honour of Prussia does not in my view consist of playing Don Quixote to every offended parliamentary bigwig in Germany who thinks his constitution is in jeopardy." 73 The basis of this course - Realpolitik - had its origins in the Olmütz speech in 1850 , and had matured over the course of the next several years. ${ }^{74}$ Its fundamental aim was to prepare the groundwork not for a Prussian takeover of Germany, but certainly for the removal of the competing Austrian influence. It was Bismarck's goal to make sure that, when this happened, he would not send his state tilting at windmills, but rather embarking it on a campaign in which victory would, as a result of his political manoeuvring, be all but assured.

\footnotetext{
${ }^{73}$ Jonathan Steinberg, Bismarck: A Life, 108.

74 The term Realpolitik has no satisfactory English equivalent, though at times it has been described as "realism." At the heart of Realpolitik is a sense of rational and ruthless diplomacy, and a means of measuring the potential success of a certain course of action against its risks. Realpolitik was conceived as a method of undertaking politics entirely through logic and reason, rather than having any emotive objectives; it is for this reason that Bismarck rejected the notion that a state with a political system based on and influenced by religion could engage in Realpolitik since, to him, faith and self-interest were incompatible, yet the state must be guided by the latter for its own good. This often meant that Bismarck could pursue foreign policy objectives well beyond the limits thought prudent by other politicians, and his course of action was not always predictable (except in hindsight.) For a good discussion of the origins, meaning and limits of Realpolitik, see Ibid., 130-133, 169-170.
} 
Already, Bismarck had made his position clear by persuading King Wilhelm of Prussia not to attend the Austrian-convened Frankfurt Diet of Princes in August 1863 yet another attempt by Vienna to force the Mittelstaaten to fall into the line of Austrian policy without affecting a national unification. Not even Franz Joseph's telegraphic appeal to his "truest friend" Wilhelm could sway the Prussian course. ${ }^{75}$ Berlin's response, nominally composed by the king, but most likely the work of Bismarck himself, admonished the Habsburg emperor. "I cannot convince myself that [your] chosen path will meet the aim [of peaceful German unity]", answered Wilhelm, "nor that this attempt has any greater or even the same chances of success as previous attempts." 76 Under Bismarck, Prussia began to create some form of cohesive German policy that would invariably put it at odds with Austria. It was this very German policy that led Bismarck to war against Denmark (albeit in conjunction with Austria) over control of the provinces of Schleswig and Holstein, and it was this war and policy that prompted Württemberg's King Wilhelm, in one of the last political acts of his life, to endorse the Prussian annexation of these territories. With Wilhelm dead, and his son an inferior political actor, the man now occupying the top office in Württemberg's political spectrum also happened to be a close personal friend of the Prussian leader.

\section{The Varnbüler Ministry and the Changing Face of Germany.}

Despite their friendship, Varnbüler was not a puppet or lackey of Bismarck. Upon taking office, Varnbüler was not unfriendly towards Austria. He had recently published a pamphlet, reprinted through the popular Schwäbischer Merkur newspaper, which argued

\footnotetext{
75 Kaiser Franz Joseph von Habsburg to King Wilhelm I. von Hohenzollern, Vienna, 6 August 1863, in Dokumente der Deutschen Politik und Geschichte von 1848 bis zur Gegenwart: Ein Quellenwerk für die politische Bildung und staatsbürgerliche Erziehung, ed. Johannes Hohlfeld, 1.Bd. (Amsterdam: Swets \& Zeitlinger, 1973), 131.

76 King Wilhelm I. von Hohenzollern to Kaiser Franz Joseph von Habsburg, Gastein, 7 August 1863, in Dokumente der Deutschen Politik und Geschichte, 132.
} 
eloquently and passionately for the rights of all Germans, including Austrians, to one central, united German homeland. ${ }^{77}$ Varnbüler insisted that the political unification of Germany would manifest itself as the outgrowth of a spiritual, cultural, social and mercantile unification of the peoples of Germany. "The national sense of a people", he wrote, "rests upon the intimate bonds of their bourgeois lives."78 While still only a deputy in the Landtag, Varnbüler was a vocal opponent of what he saw as Prussia's imperious political manoeuvres. In February 1863, for instance, Prussia had proposed a trade agreement between the Zollverein and France, a measure that Varnbüler decried as the "price of peace [through which] Prussia wishes to benefit at the cost of the national honour and national wellbeing of France, and to once and for all crush Austria." Continuing his vitriol, Varnbüler accused Prussia of "perfidy" that "endangers the Zollverein."79 Many years later, Varnbüler insisted that the intention of "the leading men in the Zollverein" (here meaning the Prussians) was to neuter the "progressively growing movement [in south and central Germany] for Austria to join the Customs Union." 80

Once at the reins of government, Varnbüler's criticism of Prussia apparently intensified. On 5 December 1864, Württemberg recommended before the Confederal Diet that the annexation of Holstein by either Prussian or Austrian authorities should be halted. Since Austria is geographically far removed from the Duchy of Holstein, nestled in the German far north, on the border with Denmark, there is little doubt that this resolution was aimed chiefly against Prussian expansionism. ${ }^{81}$ This, however, placed Varnbüler at odds with his exchange of correspondence with Bismarck in August. Over the course of a

\footnotetext{
77 Baron Friedrich Karl Gottlob Varnbüler von und zu Hemmingen, Ueber die Frage eines deutschen Heimathrechtes (Stuttgart: Verlag von Aug. Schaber, 1864), passim. HStAS.E40/16 Bü.66.

78 Ibid., 31.

${ }^{79}$ Karlsruher Anzeiger, No.43, 20 February 1863. HStAS.P10 Bü.849.

80 Baron Friedrich Karl Gottlob Varnbüler von und zu Hemmingen, Address to the 32nd Sitting of the German Reichstag, 28 April 1877. HStAS.P10 Bü.849.

${ }^{81}$ Hartwig Brandt, Parlamentarismus in Württemberg, 1819-1870, 736.
} 
handful of letters, Varnbüler had recommended to Bismarck that Prussia occupy and annex Denmark's overseas colonies - specifically the Faroe Islands - but the Prussian had demurred. 82

What was Varnbüler's game? Certainly, his early German policies seem so haphazard as to have been nearly random. As a deputy he had bitterly opposed what he saw as Prussia’s attempts to isolate Austria from the rest of Germany. Then, he had attempted to convince his friend, Bismarck, to annex Danish territories in the Baltic and North Sea, to no avail. Immediately thereafter, his cabinet issued a rebuke to the Prussians for overstepping their bounds in Holstein.

Yet there was method to Varnbüler's madness. More and more, political discourse, not just in Württemberg but in every state of Germany, focused on the unification of the German people. Varnbüler himself had published his pamphlet, in which he insisted that a united Germany was the inalienable right of the German people. Concluding that a nation should and will exist, however, is different from determining the course of that unity. Varnbüler, as experienced as he was in German affairs, was all too aware of the pervasive fear that, whatever form Germany took, it would benefit only the most powerful member, be that Austria, Prussia, or, in the case of Third Germany, Bavaria. Varnbüler was also aware that Württemberg, the archetypal Mittelstaat, would not be the guiding light of Germany. It could, however, influence the development of Germany according to whichever German model it supported. Varnbüler's policy, therefore, was to play for time, never openly declaring his allegiances, attempting to manoeuvre Württemberg into a favourable position politically, economically and militarily. Therefore, Varnbüler was following a pattern of diplomacy defined by King Wilhelm and August von Wangenheim as early as 1815 . Wangenheim had opposed both Austria and Prussia out of principle. Wilhelm opposed whichever power he felt, in the circumstances, posed the greatest threat to the good of

\footnotetext{
82 Otto von Bismarck to Varnbüler, Gastein, 16 August 1864. HStAS.P10 Bü.731.
} 
Württemberg or Germany as a whole. Varnbüler, however, recognising that Germany was on the road to unification, opposed whichever state he felt was in the ascendency, with the aim of ensuring that no single German power would dominate whichever form of Germany eventuated.

With this in mind, Varnbüler was correct to oppose Prussia's treaty with France because he feared such a move would concentrate too much power in Berlin's hands. On the other hand, his support for Prussian annexations of Danish territories was born from the assessment of the Danish War that it was the Austrians, not the Prussians, who threatened to dominate German affairs. After all, Prussia had fought with difficulty against the supposedly inferior Danes, taking significant casualties and fighting a number of indecisive skirmishes. By contrast, the Austrians had carried the day in many spectacular battles involving death-defying bayonet charges. ${ }^{83}$ Once it became apparent to Stuttgart that Prussia had gained some measure of the initiative, Varnbüler reversed the government's course again, cautioning Berlin against the annexation of the ex-Danish provinces.

Varnbüler's flexibility extended to Third Germany as well. With Austria and Prussia cooperating for once, Varnbüler drifted with the Zeitgeist of nationalist sentiments, hoping that Prussia and Austria could, in fact, coexist and lead Germany in a cooperative fashion. Accordingly, he appeared before the Landtag. "At present, I hold a unification of the smaller German states or of a selection thereof as a counterpoint against one or both of the German great powers as neither necessary nor advisable", he told the parliament. ${ }^{84}$ Given

\footnotetext{
${ }^{83}$ This was, in actual fact, not the case. The Austrians had largely carried battles only by sheer weight of numbers. The Prussians, who had originally fought poorly thanks to the inferior tactics of General Wrangel, soon found their feet. At Sandberg, the Dreyse rifles had inflicted casualties on the Danes numbering 500 percent those suffered by the Prussians. A single Prussian company, surprised on a moor at Lundby by two charging Danish companies, felled some 88 of the attackers for a loss of just three men, a kill-to-loss ratio of nearly thirty to one. Even the notoriously dismissive Austrian army staff were impressed by "this awesome result." Regardless, these successes were largely ignored by all but the Prussians themselves, while Vienna triumphantly fêted its army's achievements in the north. "Die Schiessübungen der k. preussischen Infanterie", Österreichische Militärische Zeitschrift 3 (1865), 19-20; Geoffrey Wawro, "An 'Army of Pigs", 425-428.

${ }^{84}$ Verhandlungen der Württembergischen Kammer der Abgeordneten auf dem Landtag, Ltg. 1862/65, Kammer der Abgeordneten, 83. Sitzung, 5.1.65.
} 
his past pleas for a common German cause including both great powers, Varnbüler was not acting out of character, but the address reflected the optimism of the Chamber that, perhaps, the elusive pan-German state could be created after all. ${ }^{85}$ The same sentiment appeared to spread to even the most vocal of Third Germany's supporters in the Landtag. Ludwig August Österlen, a senior and respected member of the Second Chamber who had consistently advocated a southern national bloc, also addressed the Chamber, telling his (likely incredulous) colleagues that he was "in no way an implacable supporter of the Trias." The idea of a Mittelstaaten conglomerate, Österlen claimed, was only a "sad necessity" in case agreement between the great powers had been impossible. Now, however, that did not seem to be the case. ${ }^{86}$ The early architects of Third Germany had indeed come up with the plan based on the idea that Austria and Prussia could not cooperate, and would always use the Mittel- and Kleinstaaten as proxies in a war of nerves between great powers. But the Danish War, conducted by both great powers in the name of Germany, seemed to confirm Österlen's contention that the "sad necessity" of this contingency was no more.

However, the confidence in a solution to the German question that would satisfy Prussia, Austria and the constituent states of the German Confederation was misplaced, and in spite of his words Varnbüler had not yet turned his back on Third Germany. Characteristically, Varnbüler had ameliorated his own statement to the Landtag, insofar that he explained that he saw no need for Third Germany "at present." This gave him an escape, should circumstances change. As it turned out, circumstances changed very quickly indeed.

\footnotetext{
85 Folkert Nanninga, "Zur 'deutschen' Politik des württembergischen Außenministers von Varnbüler in den Jahren 1864 bis 1870", ZWLG 32 (1973), 114.

${ }^{86}$ Hartwig Brandt, Parlamentarismus in Württemberg, 1819-1870, 737.
} 


\section{Fighting for the Heart of Germany.}

The peace following the Schleswig-Holstein affair and the Danish War was a chimera. Bismarck had taken Prussia to war against Denmark, in a coalition with Austria, because the circumstances of the time suited him to do so, not because it represented a longterm Austro-Prussian policy of detente and rapprochement. The Denmark campaign had allowed Bismarck's army to test their newest weaponry and tactics in a theatre that posed little risk. In spite of one or two failures, the Prussian army had actually performed extremely well. By contrast, it had become clear to the General Staff, and particularly Moltke, that the Austrian army insisted on following outdated, near-suicidal tactics that, if exploited by a better organised and drilled army than that possessed by the Danes, might prove fatal for the Habsburgs. Moreover, the Schleswig-Holstein affair had underscored deep divisions in the Austrian Empire's political structure, with state debt skyrocketing and the Hungarians questioning the role of the Empire in the German Confederation itself. ${ }^{87}$ So, having been suspected to attempting to remove Austrian influence from Germany by way of the FrancoPrussian trade agreement in 1863 , Bismarck had since used his tentative alliance with the Austrians in Denmark in order to test their mettle. As a committed Realpolitiker, he could hardly pass up an opportunity to rid Prussia of its major rival, as Austria had proved to be for decades. Now, this opportunity presented itself.

By Summer 1865, the optimism that had accompanied the successful joint venture in Schleswig and Holstein had evaporated. Bismarck had taken note of Austria's internal political squabbles, and he resolved to exploit them, thereby weakening Austria's position in the Elbe duchies. At the Gastein conference, which was supposed to facilitate an joint Austro-Prussian agreement on administering the two provinces, Bismarck cleverly forced the Austrians into a corner. Austria was given the rights to administer Holstein, but agreed to Prussian administration of Schleswig. Both would be admitted into the Zollverein -

\footnotetext{
${ }^{87}$ Brendan Simms, Europe: The Struggle for Supremacy, 232-233.
} 
which, as we have seen, was effectively a tool of Prussian policy. Vienna guaranteed the creation of a permanent transport corridor connecting Schleswig and Prussia, which by necessity would run through Austrian Holstein. It also sold the rights to the Elbe city of Lauenburg, which acted as a riverside border station between Prussia and Holstein, to Prussia for the sum of 2.5 million Thaler. ${ }^{88}$ While the negotiations were conducted in an apparently cordial fashion, there was no masking the result as anything other than a humiliation for Vienna and a diplomatic victory for Berlin. ${ }^{89}$

Early into 1866, the Prussians and the Austrians would once again be squabbling over the administration of the provinces. As early as 1 January, some southern newspapers were reporting the possibility of a Franco-Austrian alliance to balance Prussia's ascendency, a matter that evidently caused Varnbüler significant concern. ${ }^{90}$ In fact, the rush of information, misinformation, opinion and propaganda was overwhelming for the Württemberg government. It was also not immediately clear what precisely was at stake in the latest round of Austro-Prussian conflict. On 31 March, for example, the Austrian ambassador to Berlin, Count Alajos Károlyi von Nagykárolyi, sent a confidential note (dutifully reported in the various south German papers) to Bismarck, categorically denying

\footnotetext{
${ }^{88}$ Lothar Gall, Bismarck, Vol.1 (London: Allen \& Unwin, 1986), 272-273.

89 Austria had little choice but to accept Prussia demands at Gastein. In a confidential dispatch to London, the British ambassador to Vienna explained that Austria's financial position was by now precarious: “The Army was in its usual good condition, but the Finances required the greatest watching, there were no available funds, the Treasury was empty and all the energies of the Government must be directed to place in order the Revenues and Resources of the Empire." Thus, even though "the Emperor of Austria may feel himself injured by the late proceedings of the Prussian Government", Vienna simply could not afford to "involve the Empire in incalculable expense at a moment too when She finds great difficulty in raising money for any purpose whatever." Because of this, the Austrian foreign minister, Count Alexander von Mensdorff-Pouilly, was obliged to "make every concession to Prussia that was compatible with [Austria's] honour"; in this case, Austria's honour was best served by avoiding war. Lord John Arthur Douglas Bloomfield to Russell, No.163, Vienna, 9 August 1865, in British Envoys to Germany, Vol.IV, 509-510.

90 The response of the sympathetic Karlsruber Zeitung of Baden to this was a favourable but meek editorial, pointing out that "a formal alliance could take the form either of an offensive or a defensive alliance. [...But] Austria does not want to attack another state, nor does it have a reason to expect an attack on its territory in the near future." Varnbüler, having received this report in a diplomatic pouch from his representative in Karlsruhe, liberally underlined the most unlikely of justifications in pencil. Karlsruber Zeitung, 1 January 1866. HStAS.E70f Nr.164.
} 
that Austria would behave with hostility against Prussia. Károlyi insisted that this would be unthinkable because it would constitute "a contradiction of the provisions of Article 11 of the Confederal Act, which forbids members of the [German] Confederation from pursuing a dispute [with another member] through force."91 Károlyi’s note was neither convincing nor reassuring, especially when the press still believed Vienna and Paris to be negotiating with one another. At the same time, the two most important popular Württemberg newspapers, the Schwäbischer Merkur and the Beobachter, both insisted that Varnbüler declare the state's neutrality, having presumably recognised that war, regardless of Károlyi’s denials, was imminent.92

Varnbüler, however, rebuffed the advice of the pressmen. He, too, had decided that war was unavoidable. To George Gordon, he remarked in late March that "the present peaceful aspect of affairs is only temporary and [...] war must and will eventually break out between Austria and Prussia." Correctly reading Bismarck's manoeuvres at Gastein and earlier, Varnbüler warned Gordon that Prussia would ultimately attempt to force Austria out of its northern foothold, and then press southwards, to the line of the River Main. ${ }^{93}$ To Varnbüler, the danger of this in relation to the rest of the German states was clear enough. In typical fashion, he reasoned that it was therefore in the best interests of the Confederation, as well as Württemberg itself, if the Schleswig-Holstein problem was resolved in Austria’s favour, rather than permitting Prussia further gains in the north. As always, there was a caveat. Varnbüler noted that at that moment an agreement with Austria was favourable, but that this could change. ${ }^{94}$ What Varnbüler evidently did not realise was that Gastein had made his hoped-for solution impossible; Austria was in no position,

\footnotetext{
${ }^{91}$ Karlsruher Zeitung, 3 April 1866. HStAS.E70f Nr.164.

92 Schwäbischer Merkur, 1 April 1866; Der Beobachter, Nr.76, 4 April 1866.

${ }_{93}$ Gordon to George Villiers, Earl of Clarendon, No.21, Stuttgart, 28 March 1866, in British Envoys to Germany, Vol.IV, 390.

${ }^{94}$ Folkert Nanninga, “Zur 'deutschen’ Politik”, 120.
} 
financially, militarily or politically, to defend its claim to Holstein, and it certainly could not extend that claim to Prussian-controlled Schleswig. Nonetheless, Varnbüler's constant guiding principle was to see the dominant power as the danger to German wellbeing, and in this case that dominant power was Prussia.

Events soon after only bolstered this position. In early May, he was visited by Alexandre de Geiger, a Bavarian-born deputy in the French Corps législatif, who revealed to him "in the strictest confidence" that Bismarck was planning to annex Hanover and Saxony, "reimburse the Catholic Saxon dynasty with territory on the Rhine, and so create a security buffer between Prussia and France."95 Geiger's implication was that this "buffer" would be carved out at the expense of the other Mittelstaaten. Even more alarmingly, Varnbüler soon learned that the Bavarians had concluded that Bismarck was secretly being backed by the French. On 10 June, with war increasingly likely, Varnbüler wrote to Wächter in Paris. "The point Pfordten makes, albeit cautiously", he reported, "concerns the motivations of Emperor Napoleon. He [Pfordten] is using the same sources as we are, but quizzes them more directly, and he always sees France on the side of Prussia."96

That settled matters. In March, Varnbüler had reassured Gordon that, even if war came, he did not believe the southern states would be threatened by it. But if Prussia were allied with France, as Pfordten was convinced it was, then this introduced a new dimension to the simmering conflict. French involvement would turn what Varnbüler hoped would have been a localised conflict into a major war. Prussian victory would undoubtedly introduce a renewed French encroachment into Germany, and if Geiger's intelligence was correct, then it was entirely possible that Bismarck, governed by his Realpolitik, would bargain away the sovereignty of his friend's state to secure Napoleon III's support. Given

\footnotetext{
95 Heinrich von Poschinger, Fürst Bismarck und die Parlamentarier, 3.Bd. (Breslau: E. Trewendt, 1892), 272. 96 Varnbüler to Wächter, Stuttgart, 10 June 1866, in Die Rheinpolitik Kaiser Napoleons III. von 1863 bis 1870 und der Ursprung des Krieges von 1870/71, ed. Hermann Oncken, 1.Bd.: 1863 bis Juli 1866 (Stuttgart: Deutsche Verlags-Anstalt, 1926), 258.
} 
these circumstances, Varnbüler had little choice. The siding of Württemberg with Austria was not just an option but a necessity. 



\section{Chapter 8 \\ THE UNIFICATION OF GERMANY, 1866-1871}

THE YEARS PRECEDING 1866 were tempestuous for Württemberg and Germany. After decades of unresolved, simmering tensions between conflicting conceptions of the state's role in the region, and the general question of the nation, the sudden stream of seismic events in the political sphere became all but overwhelming. Decades of political continuity, with Wilhelm controlling the levers of state German policy, were over, and his son was hardly a suitable replacement for this astute giant of regional politics. In the State Ministry, the ascension of Karl von Varnbüler at least gave Württemberg a civil leader with a similar worldview as its deceased king, and Varnbüler quickly took the reins in place of the inexperienced King Karl. In this way, the transition from the Wilhelmine era into the Carolingian era proceeded smoother than we might expect. But Varnbüler faced a German situation far more complex than in previous years. Time and again, Third German initiatives had failed but the concept refused to die; Austrian or Prussian initiatives that seemed to promise the cooperative and beneficial unification of Germany raised hopes but invariably disappointed their Mittelstaat exponents.

And then, there was war. The origins in the Austro-Prussian War lay in Bismarck's Realpolitik; Austria's competition with Prussia had often resulted in dangerous and damaging circumstances, and Bismarck was determined to remove the menace posed by the Habsburgs once and for all. This was the rationale for a war with limited objectives; Berlin had no interest in invading and annexing the rest of Germany. Yet Bismarck was not the only Realpolitiker in German affairs. Varnbüler sided Württemberg with Austria for the entirely rational reason of wishing to avoid overwhelming Prussian hegemony. This meant that he did not slavishly follow an Austrian line, but characteristically played his own hand.

Overtaken by circumstances, Württemberg's strategy appears a failure only in hindsight; in fact, Württemberg's diplomatic manoeuvres and those of the other 
Mittelstaaten fashioned the very environment that would lead to the final unification of Germany, and the form that it took, in 1871 . To get to that point, however, Germany would be again embroiled in one final war, this time with its oldest and most implacable enemy.

\section{State and National Decisions for War.}

It is a common assumption that the south German states were naturally aligned with Austria, not Prussia; after all, they had intervened in Hesse-Kassel on Austria's behalf, and as Walter Bußmann argues, "the public opinion, above all in south Germany, positioned itself fervently for Austria and against Prussia."' As we have seen, in Württemberg the attitude toward Austria was ambivalent at the best of times. Nor is it reasonable to equate the action in Hesse-Kassel, which was a mere skirmish, with the disastrous conflagration of 1866. Württemberg's hand was forced in 1850, and its involvement in Hesse-Kassel was at best reluctant. Perhaps, then, Württemberg was fearful of the Prussians invading, taking Germany by force. Yet this seems unreasonable as well. For one, Varnbüler correctly recognised that Prussia would advance only to the Main. ${ }^{2}$ Though Geiger and Pfordten's warnings of Bismarck's designs undoubtedly shook Varnbüler's faith in his own conclusions, he could also find solace in the fact that the Prussians were not expected to do well in a war against Austria. The Austrian army had won impressive victories in the Danish

1 Walter Bußmann, Das Zeitalter Bismarcks (Frankfurt am Main: Akademische Verlagsgesellschaft Athenaion, $1968), 48$.

${ }^{2}$ Gordon to Clarendon, No.21, Stuttgart, 28 March 1866, in British Envoys to Germany, Vol.IV, 390. 
War, while the Prussians had, in some instances, performed lamentably. ${ }^{3}$ The Prussian army ultimately acquitted itself admirably against the Danes, but this truth was not readily apparent to outside observers at the time. The general consensus in 1866 was, in fact, that if Prussia went to war with Austria, even without assistance from the other member states of the Bund, then Prussia would lose.

At the same time that Pfordten told Varnbüler of his suspicions that the French were backing Prussia, he also insisted that a war against Austria would be "hopeless." Nor was he the first (or last) to express this view. At the beginning of the year, Baden's Karlsruber Zeitung pointed out that "for Austria the situation has the peculiar advantage that his back is exposed to Italy, and therefore covered, and thus he maintains a free hand in the event of any bold enterprise of Prussia, which one can only believe is most likely from the side of Count Bismarck." 5 Even after the war began, and Prussia marched successfully through Hanover, Saxony and into Bohemia, the expected outcome was still an Austrian victory. "[T]he odds are against the Prussians", Friedrich Engels wrote in the Manchester Guardian on 30 June. " $[\mathrm{I}] \mathrm{f}$ they refuse to be beaten in the first great battle by the superior leadership, organisation, tactical formation, and morale of the Austrians, and last, not least, by their

\footnotetext{
3 The Prussian forces were led by the senile Field Marshal Count Friedrich Heinrich Ernst von Wrangel, who proved unimaginative and somewhat inept. In a joint action against Danish fortifications at Oeversee on 6 February, for instance, it was the Austrians who made the breakthrough, while the flanking Prussians barely moved. When Wrangel did show initiative, it was misdirected. He decided to advance into Jutland, for instance, when Bismarck had explicitly forbidden him from doing so, and it was only after the minister-president exerted serious effort that the invasion was averted. In action, the Prussian troops initially performed poorly. At Missunde, the Prussians lost more men than the Danes did, and at Düppel in April, the Danish fortress was taken only after the Prussians had taken over 1,000 casualties. It should be remembered, though, that the Prussians also showed real mettle at Sandberg and Lundby; these less complimentary actions were the natural hiccups of a military system beginning a new experiment under Moltke's direction. Christopher Clark, Iron Kingdom, 526-529; Geoffrey Wawro, "An 'Army of Pigs", 424-425; Dennis E. Showalter, "Diplomacy and the Military in France and Prussia, 1870", Central European History 4, 4 (December 1971), 350.

${ }^{4}$ Varnbüler to Wächter, Stuttgart, 10 June 1866, in Die Rheinpolitik Kaiser Napoleons III., 1.Bd., 258.

5 It had presumably never occurred to the Badenese journalists that Italy might take advantage of Austria's moment of weakness; in the event, they did so to dramatic effect. Karlsruber Zeitung, 1 January 1866. HStAS.E70f Bü.164.
} 
own commanders, then they must certainly be of a different mettle from that of which a peace army of 50 years' standing may be expected to be." 6

At the same time, public opinion was more disposed to peace than war. The Beobachter and the Merkur were not at all impressed by the march towards conflict, and their views reflected those of their readers. They were not the only Mittelstaat papers to appeal to a southern neutrality in the coming war. In mid-April, Nassau's position of "armed neutrality" was applauded by Bavaria's Bayerische Zeitung. ${ }^{7}$ The same paper advocated a similar position, both for Saxony and for Bavaria itself, two months later. ${ }^{8}$ In Baden, the 7 May edition of the Karlsruher Zeitung, sent to Varnbüler via his consul in Karlsruhe, Oskar von Soden, contained a prescient and cutting editorial, in which the proprietors urged the southern states not to go to war on behalf of the Confederation; "at the first cannon shot between Austria and Prussia, there is no German Confederation, and no German Confederal Army Corps any longer." ${ }^{\prime}$ The press, reflecting southern public opinion, saw the possibility of war as being disastrous for Württemberg, its neighbours, and all of Germany.

So, if public opinion in Württemberg, and in its compatriot Mittelstaaten, favoured neutrality over belligerence, if there was no impending concern that Austria would lose the war, and if considerations of the German Confederation were effectively irrelevant — given that war would dissolve the Bund - why did Varnbüler take Württemberg to war? There were, in fact, numerous reasons to do so. Firstly, there was the matter of practicality. Württemberg was a Mittelstaat, and in this case the name is fitting. If Austria and Prussia came to blows, Württemberg, Bavaria, Hanover and Saxony would all be directly in the middle of the two warring powers. The Mittelstaaten were the "disputed acre" that both

\footnotetext{
6 "Notes on the War, No.1", Manchester Guardian, 30 June 1866.

${ }^{7}$ Bayerische Zeitung, Nr.103, 14 April 1866.

${ }^{8}$ Bayerische Zeitung, Nr.155, 6 June 1866.

${ }^{9}$ Karlsruber Zeitung, 7 May 1866. HStAS.E70f Bü.164; Baron Oskar von Soden to Varnbüler, Karlsruhe, 7 May 1866. HStAS.E70f Bü.164.
} 
Prussia and Austria had been trying to plough for nearly fifty years. Caught between the "eternal Great" and the "eternal Lesser", as Wangenheim had reflected in 1833, the Mittelstaaten were at "the power of null", without any ability to grow in strength while caught between regional superpowers. ${ }^{10}$ There was no reason to suspect that the Austrians would perform poorly in a war with Prussia. Logic and the evidence of the Danish War dictated that the Prussians, whatever their motivation and drive, however well-drilled their army, were no match for the larger and (supposedly) tried and tested Austrian army. Thus, if Württemberg did not ally with Austria, and the Austrians succeeded in smashing the Prussian army — and that, surely, was a given — what then? Would Austria seek crippling retribution against the 'cowardly' neutral powers? Could Austria, in their manoeuvres to draw the Prussian army into battle, move their corps, regiments and battalions into Swabian territory as a strategic measure? If so, what would neutrality achieve?

Württemberg and Bavaria, in particular, stood to lose the most from the AustroPrussian War, as their territories stretched as an uncomfortable buffer between the two belligerents. As Belgium would find in 1914, neutrality would surely become the first casualty to expediency. This was the same difficulty Württemberg faced in 1830 and 1831, when Wilhelm contemplated allowing French soldiers free passage. Varnbüler had reasonable justification to believe that, even if Stuttgart declared neutrality, Württemberg would soon be overrun by the Austrian troops who could mass along the southern border. The Mittelstaaten were, after all, caught in the middle; therefore, the Mittelstaaten would probably constitute the battleground for this clash of the titans.

Württemberg certainly had something to fear from the south. However, threat also existed in the north and west. Varnbüler had made it clear to Pfordten as early as December 1864 that "I will not agree to any confederal decision whose consequence is a war against

10 Baron Karl August von Wangenheim, Die Wabl des Freiherrn von Wangenheim, K. Würtembergischen Staatsministers ausser Dienst, zum Abgeordneten in die Würtembergische Ständeversammlung (Tübingen: Heinrich Laupp, 1832), II. 
Prussia."11 Now, though, Pfordten was convinced that Bismarck had the shadowy backing of Paris. Varnbüler may have chalked this theory up as a paranoid conspiracy invented in the mind of the Bavarian minister-president, but for the fact that he had also received a similar warning from the French deputy, Geiger. Though Württemberg's diplomatic relations with France were generally positive, the memories of the Napoleonic Wars remained, and with them a suspicion of French intentions. Certainly, Varnbüler could not doubt that Bismarck might have made a deal with Napoleon III; if the Prussian ministerpresident felt that he would gain an advantage from such a relationship, then Realpolitik practically demanded that the deal be made. If Prussia and France were allied, this was reason enough for Varnbüler to feel compelled to resist them.

Yet not even this fully explains Württemberg's siding with Austria. At the end of May, the British ambassador to the German Confederation, Sir Alexander Malet, addressed a letter to the Diet, proposing a solution to the pending crisis. The powers of Europe, he said, were concerned by the hostility between Austria and Prussia. Therefore, a conference was to be convened in Paris. Representatives of Britain, France and Russia would hopefully be joined by plenipotentiaries from all of the German states. Malet added that "the negociations $[s i c$.$] will have all the better prospect of success if they are not disturbed by the$ clash of arms and by the susceptibilities arising out of points of military honour." ${ }^{2}$ Whatever rumours and concerns Varnbüler had heard, be they from French representatives, Bavarian politicians or his own sources, here was a concerted effort by three European great powers (including France) to avert the very war that the Württembergers believed the French to be encouraging. It is significant, then, that opposition in the Diet to Malet's invitation came from Württemberg representative, the former state minister Joseph von

\footnotetext{
11 "Report of 4.2.1865", Stuttgart, 4 February 1865, in Quellen zur deutschen Politik Österreichs 1859-1866, ed. Heinrich Ritter von Srbik, 4.Bd.: März 1864 bis August 1865 (Oldenburg: Stalling, 1937), 548.

${ }^{12}$ Malet to Baron Alois Kübeck von Kübau, President High Diet, Frankfurt am Main, 27 May 1866. HStAS.E65 Bü.106.
} 
Linden. Linden argued that a peace conference of the German and neutral powers in Paris was desirable, but limits had to be placed on its scope and competence. The involvement of any of the German states in affairs outside of Germany, for instance, was fair game, and to that end, the question of the Duchy of Schleswig could be discussed, "insofar Schleswig lies outside the German Confederation.” Italy was a more thorny problem, and Linden foresaw problems in Britain, France and Russia mediating either Austria's involvement in Italy or Prussian contact with Cavour's government, since Italy, according to the diplomat, straddled both European and German interests. On the matter of the Confederation itself, including Schleswig-Holstein, Linden was uncompromising. The conflict between Austria and Prussia was a constitutional matter, and as a result it was a "purely internal affair, which according to Article VI of the Confederal Acts is only to be handled by Germany."13 Linden — and by extension his superior, Varnbüler — could surely not have believed that the Paris peace conference could go ahead given these restrictions, though they at least went through the motions of appearing conciliatory, going so far as to suggest that Pfordten should act as the Confederation's representative in Paris. This, however, was windowdressing, which London, Paris and St. Petersburg soon realised; Malet's reproachful response on 14 June reflected "the disappointment of the expectations which Europe might have entertained of a successful issue of the Conference."14

Württemberg's aggressive reply to the abortive Paris peace initiative suggests a state set on war, not a state desperate to avoid it. Indeed, every apparent attempt of the Mittelstaaten to mediate the brewing conflict came either too late or else was tainted by contrarian movements. Stuttgart's suggestion of Pfordten as emissary to the Paris conference, while denying the conference the oversight to address the immediate and pressing issues, is one such example. Another is the proposal offered by Bavaria, just two

\footnotetext{
13 Baron Joseph Franz Peter von Linden, Address to Bundestag, 1 June 1866. HStAS.E65 Bü.106.

${ }^{14}$ Malet to Kübeck, Frankfurt am Main, 14 June 1866. HStAS.E65 Bü.106.
} 
days before war was declared, to replace both Prussian and Austrian troops at confederal fortresses with a joint Mittelstaat contingent. As Prussia rightly pointed out, such a supposedly peaceful movement could hardly be taken seriously, given that Bavaria and many of the other smaller states had by now begun mobilising. The peacemaking efforts, therefore, were entirely disingenuous. However, this is not to say that the authorities in Stuttgart threw themselves wholeheartedly into the cause of making war. Instead, the Württemberg war effort was ineffectual and lethargic, and this lethargy was not by accident but by design.

\section{Württemberg at War.}

Two days after Malet had expressed his disappointment with the German Confederation's unwillingness to negotiate a peace between Austria and Prussia, the now-inevitable war erupted. Well-drilled Prussian soldiers of the West Army, divided into three contingents under Generals Goeben, Manteuffel and Beyer crossed the borders of Hanover and HesseKassel, while the Elbe Army crossed into northern Saxony, using the dense and orderly modern rail and road networks lining the landscape of the northernmost Mittelstaat. The offensive movement was hardly a surprise, since the threat of war had hung over Germany for at least several months and, as we have seen, neither Varnbüler nor his fellow southern leaders were oblivious to it. ${ }^{15}$ In the opening days and weeks, though, the Württemberg contingent of the VIII Corps — and indeed, most of the corps itself — displayed a singular lack of urgency. Named as commandant of the VIII Corps was Prince Alexander of HesseDarmstadt, the same career soldier who had accompanied the Austrian delegation to Villafranca in 1859. The mistrust of him due to his Austrian service still hung in the air, seven years later. Each state army contingent in the corps was commanded by an officer

\footnotetext{
15 See, for example, Hildegard von Spitzemberg's diary entries from January to June 1866, underscored in almost every instance by the ominous build-up to war. Hildegard von Spitzemberg, Tagebuch, 66-67.
} 
from that state, and these commanders were nominally subordinate to Alexander, yet none of them would follow his orders until he renounced his oath of loyalty to the Austrian throne. ${ }^{16}$ This he delayed until 17 June, the day after Prussia had begun its movements through northern Germany, but even then the Württembergers were reluctant to take any initiative. The Württemberg army, after all, made up the lion's share of the 35,000-strong VIII. Corps - its contingent suborned to Alexander supposedly numbered 14,000 men so its mobilisation and readiness was arguably Alexander's most pressing need.

Some Württembergers, at least, saw the need for immediate action. By midmorning of the first day of the war, a full twenty-four hours before the Württemberg commander, War Minister Lieutenant General Oskar von Hardegg, agreed to submit to Prince Alexander's authority, an army observer sent a telegram to the Ministry of Foreign Affairs in Stuttgart, urgently requesting that an infantry brigade be sent to Frankfurt immediately. ${ }^{17}$ The request was prescient, given that the Prussian West Army was bearing down on the seat of the Confederal Diet with some 30,000 men. In response, the next day one brigade of 5,000 soldiers left Stuttgart bound for Frankfurt. ${ }^{18}$ While this was, perhaps, an impressively rapid response to the sudden emergency, further deployments were glacial. The second contingent of 5,000 men would not be ready to leave their home barracks in Stuttgart for another eleven days, while the remaining infantry brigade only mobilised on 5 July, which was for all intents and purposes far too late to have any bearing on the course of the war. ${ }^{19}$

Outside the infantry, mobilisation was even slower, or else did not happen at all. On 18 June, two days after the urgent request for troops, and a day after Prince Alexander ordered the entirety of VIII Corps to Frankfurt to protect the seat of the Confederation,

\footnotetext{
16 Geoffrey Wawro, The Austro-Prussian War, 74.

${ }^{17}$ Colonel Wagner to Ministry of Foreign Affairs, No.638, 16 June 1866. HStAS.E271c Bü.803.

18 Hildegard von Spitzemberg, Tagebuch, 67.

${ }^{19}$ Geoffrey Wawro, The Austro-Prussian War, 74.
} 
two of the Ludwigsburg garrison's three artillery battalions were still at Ludwigsburg. Just one battalion, comprising 426 men, 324 horses and eight field guns, had been deployed. Even then, it was sent to Schweinfurt, in northern Bavaria, to support VII Corps in case the Prussian army now attacking Saxony pushed into Upper Franconia. Worse, the munitions division, made up of 188 men and their supplies for Württemberg's artillery battalions, had for some reason been sent to Geislingen, approximately 70 kilometres southeast of Ludwigsburg, and nowhere near the most likely battlegrounds. Of Ludwigsburg's six cavalry units, numbering some 340 horses, only one had been deployed: No.4 Regiment, comprising fifty horses, which had also been sent to Schweinfurt. ${ }^{20}$ Ten days later, the disposition of these units was largely the same as it had been on the 18th, with one exception: one artillery foot battery, of 228 men, 169 horses and eight guns, had been redeployed to Bietigheim, a small town just south of Karlsruhe, in Baden. ${ }^{21}$

So, as Prussian forces invaded the German heartland, and the VIII Corps was ordered to Frankfurt to fend off Manteuffel's advance, the bulk of the corps deployed in a dribble rather than a flow. Prince Alexander should have been able to count on 14,000 Württembergers in his planned defence of Frankfurt. Instead, those at his disposal numbered only one-third of that, and it would take two and a half weeks for the the full force to become available. Moreover, the majority of the forces at the largest cavalry and artillery garrison in Württemberg never left their home base. Those that did were placed in deep defensive positions that contributed nothing to VIII Corps' war efforts.

None of this was accidental, nor was it unique. Alexander's chief of staff, the Württemberg General Fidel von Baur, was responsible for the administration of VIII Corps. In this role, he was able to follow Varnbüler's instructions to delay the mobilisation of the Württemberg contingent and, indeed, the entire corps, for as long as possible. Baden

${ }^{20}$ Garnison Ludwigsburg, Dislokation der Truppen am 18. Juni 1866. HStAS.E271c Bü.805.

${ }^{21}$ Garnison Ludwigsburg, Dislokation der Truppen am 28. Juni 1866. HStAS.E271c Bü.805. 
also vacillated and delayed. Yet Württemberg's delay was significantly more damaging, as its forces made up the bulk of the Alexander's corps. The Bavarians, though not attached to VIII Corps, also dithered. Having begun mobilising in April, by May they had just 10,000 men ready to fight. 22

The south German corps, therefore, promised much but delivered little. The beleaguered Hanoverians in the north discovered this to their cost. Hanover had also thrown its lot in with Austria, and had been invaded on the first day of the war by the Prussian Elbe Army. The Hanoverian army was substantial in its own right, with an effective strength of 19,000 men, but it was no match for the 40,000 Prussians swarming over the border. Consequently, the Hanoverians retreated rapidly to the southern university city of Göttingen, expecting that either the Bavarians or the combined south German VIII Corps would march north to join them in a counterattack. ${ }^{23}$ The reinforcements never came. VIII Corps was woefully undermanned and undersupplied, and Prince Alexander was compelled to remain in Frankfurt and wait for the Badenese and Württembergers to arrive, before even contemplating a counteroffensive. As for the Bavarians, they preferred to keep their forces at home, out of harm's way. The hapless Hanoverians continued their orderly but increasingly desperate retreat southwards, hemmed in by the enemy to the north and the hilly, heavily forested terrain to the south. On 26 June, aware that Hanover's army was in danger of total annihilation, the French foreign minister, Éduard Drouyn de Lhuys, called upon the Bavarian ambassador to Paris, August von Wendland. Drouyn was furious; to him, it was "incomprehensible how Bavaria had left the poor Hanoverians so helpless", especially when "the greatest mass of troops of the Bavarian Army stands in Franconia, and

\footnotetext{
22 Geoffrey Wawro calculates the potential strength of the Bavarian Army at 100,000 men. In 1867, Wolfgang Menzel suggested that the figure was closer to 80,000. Menzel also claimed that, by the time the war ended, Bavaria had called up some 65,000 men for service, though whether they had actually reported for duty and been assigned and armed is extremely unlikely. In any event, what is certain is that the vast bulk of the Bavarian Army never saw action. Geoffrey Wawro, The Austro-Prussian War, 74; Wolfgang Menzel, Der Deutsche Krieg im Jahr 1866, in seinen Ursachen, seinem Verlauf und seinen nächsten Folgen, 2.Bd. (Stuttgart: Adolph Krabbe, 1867), 6.

${ }^{23}$ G.B. Malleson, The Refounding of the German Empire, 1848-1871 (London: Seeley \& Co., 1904), 125.
} 
in such cases one must surely take risks." The French saw the likely defeat of the Hanoverians as both a humanitarian and a political disaster. In response, Wendland was sober and clinical. There was no point sending the army north, he said, because "it was much too late."24 The next day, the Hanoverians engaged a smaller Prussian advance force mostly made up of Landwehr reserves, and managed to repulse them. But the victory had come at a cost of some 2,000 Hanoverian soldiers, and consequently the remainder of the army surrendered the very next day. ${ }^{25}$

Hanover had lasted two weeks. Saxony, on the other hand, had lasted just two days before it was occupied, and the Saxon Corps retreated into Bohemia to join the Austrians. Hesse-Kassel and Nassau, meanwhile, did not resist at all. In Kassel, the occupying forces received a generally pleasant reception, while Nassau's Landtag, debating itself into circles about whether the preferred outcome of the war was a Prussian or an Austrian victory, amused itself with patents for "a method for the odourless evacuation of outhouses" as the Prussians approached. ${ }^{26}$ In none of these instances did any Württemberg troops intervene. Nor did they react when the Prussian First Army, briefly held in reserve to defend against an Austrian attack against East Prussia that never came, invaded Bohemia on 19 June. The Württemberg leadership seemed to believe that the Austrians could at least hold their own, and that the confederal corps were not actually required. Even after Hanover, Hesse-Kassel, Nassau and Saxony had fallen, and the First Army began its march towards the Jičín plateau in central Bohemia, Varnbüler, Baur and Hardegg continued their leisurely mobilisation.

The Württemberg army had been the very model of a smaller state army for the previous decades. Outside observers had generally been impressed by the level of training,

\footnotetext{
${ }^{24}$ Baron August von Wendland to Baron Karl Ludwig von der Pfordten, Paris, 1 July 1866, in Die Rheinpolitik Kaiser Napoleons III., 1.Bd., 288.

25 Hans A. Schmitt, "Prussia's Last Fling: The Annexation of Hanover, Hesse, Frankfurt, and Nassau, June 15 October 8, 1866”, Central European History 8, 4 (December 1975), 322-323.

${ }^{26}$ Ibid., 323-327.
} 
professionalism and organisation of the Württemberg troops during their peacetime manoeuvres. For this accomplished military force to be so pathetic in its mobilisation is difficult to fathom. Yet Varnbüler had ordered Baur to slow VIII Corps' deployment as much as possible, and the delay was noticeable enough for Alexander to suspect foul play. He wrote a reproachful letter to King Karl in Stuttgart, asking acidly whether the VIII Corps should be disbanded, or whether Württemberg would decide to take part in the war after all. ${ }^{27}$ Alexander's rebuke had little result.

\section{Revival and Opportunity: Third German Regionalism in 1866.}

In fact, Varnbüler's intention was to keep Württemberg forces clear of any action. A war between Austria and Prussia would be a protracted conflict, he thought, for while it was widely believed that Austria would be victorious, the Prussians were certainly not weak. Traditionally, battles were long, grinding affairs; an army would reach a predetermined point where it would meet its opposing force, stop, gradually build strength, fight, regroup and recover, and finally move on. Austria had the numerical advantage over Prussia, but it was unlikely that any of the engagements (at least, in the early part of the war) would prove so decisive that they would break the back of any one of the armies, and this coupled with the slow nature of nineteenth century warfare would logically preclude a speedy victory and end to the war. Nor was it likely that either power would sue for peace. The tensions between Austria and Prussia had been brewing for decades, and had only become more pronounced since 1848 . The indications were that 1866 would be the ultimate battle between Austria and Prussia for supremacy, that it would last at least for several months, and that both major powers would be preoccupied with each other.

27 The Campaigns of 1866 in Germany (London: Harrison and Sons, 1907), 386; Egon Caesar Conte Corti, The Downfall of Three Dynasties (Freeport: Books for Libraries Press, 1970), 177. 
This, then, was the perfect opportunity for the rise of a southern German federation, and the circumstances had been handed to Third Germanists by the two great powers themselves. The aspirations of the Third Germanists had been killed off in 1859 by several degrees of uncertainty. The southern states, particularly Württemberg, had dithered, and though they had recognised the opportunity afforded them by the war in Italy, the limited French objectives had scotched that opportunity before it could be exploited. The war simply had not lasted long enough, it was too limited in scope, and no one could be sure of the reaction of the other European powers. On the other hand, 1866 was several orders of magnitude more favourable. Moreover, Württemberg's leader in 1859, King Wilhelm, had been astute and clever but also old; his sense of political adventure and his desire for a regional bloc were overruled by an abundance of caution. The state minister in 1866 , Varnbüler, was cut from much the same cloth in terms of his ideas of Germany, but he was significantly youngers, and more willing to take chances. Crucially, Varnbüler's close relationship with Pfordten in particular meant that he was not playing a lone hand. Instead, he was acting in conjunction with his southern neighbours towards the same objective.

The nature of the conflict complicated matters in some ways. The rejection of neutrality as a realisable goal required the Mittelstaaten to ally with one of the great powers, and under the circumstances that could only be Austria. Yet that support could not afford to be strong, because providing this would likely risk direct confrontation with the Prussians. This had to be avoided. The Badenese Karlsruber Zeitung, reflecting the planning in the southern halls of power, editorialised on the dangers a month before the war broke out. As long as an Austro-Prussian conflict was limited to Saxony and Bohemia, the paper claimed, there would be little danger to the other Mittelstaaten. However, "as soon as the first shots are fired in Darmstadt, Mainz or Rhenish Baden, that is a different thing altogether, and the French guards in Chalons would soon find the smell of powder smoke wafting past their noses." On the other hand, if the war did not escalate, Baden would be 
able to "follow the natural development of things" with "a certain calm", even though such a war would almost certainly result in "the destruction of the Confederation." 28 To some degree, Malet had also predicted this response by the south, the month before he had approached the Diet with the offer of mediation. The southern states, he felt, were bound only by "individual fears" to "the destines of the [Austrian] Empire." If war came, he informed the Foreign Office, Austria would go to war backed by "lukewarm friends" who would provide, at best, "half reluctant aid."29 Malet was right about the level of enthusiasm for Austria (or the lack thereof) in the southern states, but incorrect about the guiding principles of those states. As the Karlsruber Zeitung suggested, even though the war would mean the dissolution of the German Confederation, this was not seen as a catastrophic event. Rather, it would be something that would lead to a "natural development" of the Confederation, such that the southern German states would cooperate more closely with one another. ${ }^{30}$ Indeed, the only danger, the journalist felt, was if Prussia was compelled to fight further west than Saxony, which could lead to France entering the war.

The solution was to avoid contact with Prussian forces from West Army, which is precisely what VIII Corps, against Alexander's will, did. Without the bulk of his force, Alexander could not hope to mount a reasonable defence of Frankfurt when the Prussians came, and VIII Corps would surely be forced to retreat without doing battle. There is also no doubt that, as war threatened, the Württemberg diplomatic corps was preoccupied not with bartering peace, but with negotiations for Third Germany. Wächter, in Paris, had discussed the very issue with the French head of the diplomatic mission to Stuttgart, Auguste Denys de Damrémont, as early as April 1866. Damrémont, like Malet for the

\footnotetext{
${ }^{28}$ Interestingly, the author of this editorial seems to believe that Saxony would be an acceptable casualty of the war, once more demonstrating the fluid and inconsistent nature of the Third German membership. Karlsruber Zeitung, 7 May 1866; Soden to Varnbüler, Karlsruhe, 7 May 1866. HStAS.E70f Bü.164.

${ }^{29}$ Malet to Clarendon, No.60, Frankfurt, 5 May 1866, in British Envoys to Germany, 1816-1866, Vol.IV, 85.

${ }^{30}$ Karlsruber Zeitung, 7 May 1866. HStAS.E70f Bü.164.
} 
British, was well-placed to recognise the sometimes clandestine manoeuvres and objectives of the Mittelstaaten. Malet's diplomatic career had by now spanned more than forty years, and beyond his early postings in Russia, France, Portugal, Sardinia and the Netherlands, his German postings had begun in Vienna, before taking him to Stuttgart and Karlsruhe, before he was finally named Britain's representative to the Confederal Diet in 1852. Damrémont, younger than his British counterpart, had three major postings under his belt, but each of them to important Mittelstaaten: Darmstadt between 1853 and 1857, Hanover from 1857 to 1860 , and Stuttgart between 1861 and 1867.31 Also like Malet, Damrémont seems to have built close relationships with the various officials of the states to which he was assigned. Damrémont felt free to discuss sensitive issues with Württemberg diplomats and vice-versa; such was clearly the case when Wächter met with him to discuss the general state of affairs in Germany.

What is striking is that the French diplomat was not only aware of the near-constant Third German negotiations that had taken place for many years, but he was also supportive of them. On 15 April, Wächter reported to Varnbüler that "the idea of the third group of states, to which the minister returned time and again, agreed with him a great deal." Damrémont, however, did sound a note of caution, warning Wächter that Württemberg would have to "count on Bavaria", because only with the support of the largest Mittelstaat would "the united state [...] be afforded the power to hold in check not just Prussia, but Austria as well."32 Damrémont was correct to warn the Württembergers of the folly of going ahead with the Third German project without Bavarian support, as this had handicapped many similar initiatives in the past. For once, though, Bavaria was a dependable ally. At the top of the state hierarchies, Varnbüler and Pfordten respected each

\footnotetext{
31 Tobias C. Bringmann, Handbuch der Diplomatie 1815-1953: Auswärtige Missionschefs in Deutschland und deutsche Missionschefs im Ausland von Metternich bis Adenauer (Munich: K.G. Saur, 2001), 184-189; British Envoys in Germany, 1816-1866, Vol.IV, 538.

32 Wächter to Varnbüler, Paris, 15 April 1866, in Die Rheinpolitik Kaiser Napoleons III., 1.Bd., 136.
} 
other, politically and personally. They discussed German affairs frankly, and Pfordten was more than willing to share his analysis of international relations with his Württemberg offsider. Pfordten had also been a longtime supporter of the Third German initiative. The mutual regard was enough for Württemberg to recommend Pfordten for the role of an authorised representative of the German Confederation in the abortive peace conference in Paris, and when war was ultimately declared, Württemberg defied its obligations to VIII Corps by sending a significant contingent of its own artillery and a detachment of cavalry to Schweinfurt to support its ally. Thus, for the first time, Württemberg, Bavaria and Baden were cooperating on a cohesive German policy. Their role was to avoid provoking Prussia, while nominally supporting Austria, and propagate the war so that it would last long enough for them to take full opportunity of the disorder.

To this end, the War Ministry in Stuttgart followed a series of otherwise bizarre priorities. For instance, it delayed issuing a requisition order for civilian horses until July. In the last days of June, however, the ministry drafted an "Appeal to the Women and Girls", requesting that communities weave and donate to the war effort armbands of black, red and gold, to be circulated to the troops of VIII Corps. Official and unofficial sources trumpeted the use of the nationalist colours for the Confederal troops, but this appeal came at a time when the second contingent of Württemberg infantry was only just deploying from its Stuttgart barracks, neither the artillery nor cavalry were in a position to assist Alexander's slowly assembling forces in Frankfurt, and the supply organisation for the artillery was 
spread across countryside, hundreds of miles from where it was needed. ${ }^{33}$ The Württemberg army was therefore avoiding contact with the enemy, while the Württemberg political leadership waited for the Prussians and the Austrians to wear each other down.

1859 had been a failure for Third Germany because France had been unwilling to push the Austrians further than it felt necessary to its immediate goals. 1866, however, proved another disappointment for the aspirations of the south Germans for another reason entirely. No one had discounted the Prussians, but it was widely believed that they simply could not match the Austrians. On the contrary, the Prussian army had spent the better part of the fifteen years since the humiliation at the negotiating table at Olmütz preparing to return the favour on the battlefield. In Helmuth von Moltke, the Prussians had a brilliant strategist and tactician leading the General Staff. Moltke delayed the push into Bohemia for a couple of days because of the danger that the Austrians might attempt to break into East Prussia and head for Berlin. When that did not happen, Moltke ordered the First and Second Army into Bohemia in an invasion of astonishing and unprecedented speed and efficacy. The Prussians met and defeated smaller units of the Austrian army on each consecutive day between 25 and 28 June. ${ }^{34}$

\footnotetext{
33 Not even the Appeal to the Women and Girls was a success. The Ministry of War first issued the call for armbands on 25 June, and a ministry memorandum indicates that "approximately 20,000" would be required. By 5 July, even though the Neues Tagblatt had since rerun the advertisement twice (at cost of $4 \mathrm{fl} .20 \mathrm{kr}$., but provided free of charge to the Ministry of War), only approximately 3,500 had been promised. Of these, the greatest contributors appear to have been the Countess von Taube of Stuttgart, who organised 880, the town of Isny, which donated some 840, and a Mrs. Böttigheimer of Friedrichstraße, Stuttgart, who offered the ministry 500 armbands at a charge of $7.5 \mathrm{kr}$. apiece. Therefore, in spite of Hildegard von Spitzemberg's enthusiastic claim that "the entire VIII. Army Corps wears the German colours", there were in actual fact not enough armbands even to account for Württemberg's first infantry contingent, which had been sent to Frankfurt on 17 June. Württemberg Ministry of War, "Aufruf an die Frauen und Jungfrauen”, Stuttgart, 25 June 1866; Württemberg Ministry of War to Lieutenant-General Fidel von Baur, Stuttgart, 25 June 1866; F. Böttigheimer to Württemberg Ministry of War, Stuttgart, 30 June 1866; Isny Council to Württemberg Ministry of War, Isny, 4 July 1866; Countess von Taube to Württemberg Ministry of War, Stuttgart, 5 July 1866; Receipt from Neues Tagblatt to Württemberg Ministry of War, 12 July 1866. HStAS.E271c Bü.848. Hildegard von Spitzemberg, Tagebuch, 68.

34 Between these days, the Prussians and the Austrians met at Podol, Náchod, Skalitz and Münchengrätz. The Austrians managed to beat a small Prussian force at Trautenau on 27 June, but lost almost 5,000 men in the process. Geoffrey Wawro, The Austro-Prussian War, 128-180.
} 
Still, there was no inkling among the Mittelstaaten that this would continue. On 28 June, Varnbüler's daughter Hildegard noted in her diary that, according to a telegram from Stuttgart, the Austrians had halted the Prussian advance both at Náchod and Münchengrätz. Here was evidence of Austria's great military prowess: "prisoners, dead and wounded litter the battlefield", and the Austrians had managed to capture 20 guns. The victory was so decisive that the Prussians had apparently "requested a ceasefire, which they did not receive." The newspapers ran the story with ever-increasing dramatic depictions of the thrilling battle. Only two days later would it be realised that the reports were entirely false. ${ }^{35}$ In fact, it was Prussia that had beaten the Austrians convincingly at both Náchod and Münchengrätz. The day before this about-face, the Prussians had also won a major victory at Jičín, inflicting over 5,000 casualties on the Austrians and the Saxon Corps supporting them, and taking Austrian casualties to that point in the war somewhere towards the region of 20,000, with 15,000 prisoners taken. By contrast, the Prussian losses had been negligible. ${ }^{36}$ "The [Austrian] Army of the North has suffered a complete disaster", Mensdorff wrote in confidence to the ambassador to France, Richard von Metternich, ${ }^{37}$ on 2 July. The only hope Mensdorff could muster for the army was that "at least they've had two days of rest."38 Perhaps this rest was necessary; indeed, the Austrian army was exhausted even without engaging in battle. Forced marches from the eastern provinces had left the bulk of the army without sleep, and inadequate supply chains meant that food and drink were chronically lacking. 25,000 troops went unfed on 23 June due to the gridlock along the marching routes; the supply wagons simply could not reach the men. By the next

\footnotetext{
35 Hildegard von Spitzemberg, Tagebuch, 68.

36 Bismarck to Johanna von Bismarck, Jitschin, 2 July 1866, in Fürst Bismarcks Briefe an seine Braut und Gattin, ed. Herbert von Bismarck (Stuttgart: J.G. Cotta'sche Buchhandlung, 1900), 571.

${ }^{37}$ Richard von Metternich was the son of the more prominent Klemens von Metternich.

38 Count Alexander von Mensdorff-Pouilly to Prince Richard von Metternich, Vienna, 2 July 1866 (2.30pm), in Die Rheinpolitik Kaiser Napoleons III., 1.Bd., 297; Mensdorff to Richard von Metternich, Vienna, 2 July 1866 (9.50pm), in Die Rheinpolitik Kaiser Napoleons III., 1.Bd., 298.
} 
day, most of the Army of the North's infantry required repairs to their boots, the leather of which had been worn out from nine days of tireless marching over difficult terrain, yet the army's supplies lacked the spare material necessary to provide the troops adequate footwear. ${ }^{39}$ Nonetheless, the army continued marching, at times engaging the Prussians in piecemeal battles, until finally the bulk of it arrived at the high ground near Königgrätz, in Bohemia. Here, at the advance defensive positions, the Austrian army would make its stand. On 3 July, the Prussian army pounced on the Austrians outside Königgrätz. The Austrian commander-in-chief, Ludwig von Benedek, had made a crucial error in making his stand where he did. The Austrian positions were not at all defensible in an era of modern warfare, especially when the Prussians were equipped with state-of-the-art rifled needleguns, not to mention the latest in Krupp rifled artillery. "Army Command must never have seen this terrain", one Austrian officer complained in an 1867 report on the battle.40 Over the course of the morning, the combined Austro-Saxon forces of some 240,000 men defended their positions against a force numbering only 135,000; even when Prussian reinforcements arrived in the afternoon, they were only 110,000 strong, giving the Prussians a very slight total numerical advantage. But Benedek's entire disposition had been defensive, and he had allowed his army to sit and be bombarded by Moltke's armies. As a result, Benedek’s defence of Königgrätz was a disaster for Austria. The army had lost onetenth of its men $-24,000$ - killed or wounded, while 20,000 were taken prisoner, and some 200 artillery pieces were destroyed or captured. Against this, the Prussians had lost just 9,000 men. Worse, the Austrians had been totally demoralised, and any fighting spirit was gone. ${ }^{41}$ When night fell and called an end to the carnage, there could be no doubt that Austria had lost not just the battle, but also the war.

\footnotetext{
${ }^{39}$ Geoffrey Wawro, The Austro-Prussian War, 124-127.

40 Ibid., 208-210.

${ }^{41}$ Ibid., 274.
} 
In spite of Mensdorff's pessimism on 2 July, and the generally poor condition of the army, Königgrätz still came almost as a complete surprise, both to the Austrians and to Mittelstaat observers. Certainly, Varnbüler and Pfordten never believed that the Austrian war effort would collapse so completely as it did on 3 July. Nor did the Viennese leadership. "The intelligence was so unexpected", Bloomfield wrote to Clarendon after the news of the defeat filtered through to the Austrian centre, "and the defeat so complete, that it has caused general consternation and dismay." The defeat was so crushing, so decisive and so devastating that the rumblings of public uprisings began to ripple through Vienna; though they did not result in revolution, Bloomfield noted that, had they done so, "there are hardly sufficient Troops in their garrison to maintain order." The rest had been sent to the front, only to be destroyed by Moltke's precision manoeuvres and overwhelming force. ${ }^{42}$ Under the circumstances, there was no way that Austria could possibly continue its war effort.

Königgrätz was a watershed moment. From the moment that Prussian troops engaged Benedek's troops, Austria ceased to be the great power it had once been. What was left of its Army of the North limped from the battlefield incapable of taking any further part in hostilities. According to A.J.P. Taylor, "Germany was conquered not united." 43 But was this the case? Officially, the war would drag on until the signing of the ceasefire in Nikolsburg on 26 July, and in time Prussia would fight several more battles. However, these were minor in character and scope. Bismarck's objective was not to absorb or destroy Austria, nor indeed Germany. Prince Alexander of Hesse-Darmstadt, having never quite mustered the full strength of VIII Corps for the defence of Frankfurt, was asked by the Diet on 11 July to remove his soldiers from the city, which was subsequently declared open

\footnotetext{
42 Bloomfield to Clarendon, No.411, Vienna, 5 July 1866, in British Envoys to Germany, 1816-1866, Vol.IV, 513-515.

${ }^{43}$ A.J.P. Taylor, Course of German History, 121.
} 
to the Prussians. ${ }^{44}$ The day before, a small force of Prussians attempted to capture a Bavarian railyard at Bad Kissingen, and was kept at bay by a disciplined garrison of Bavarian soldiers, who were eventually forced to withdraw. Simultaneously, the Bavarians successfully defended the small town of Hammelburg, a short distance southwest of Kissingen. ${ }^{45}$ The Hesse-Darmstadt contingent of VIII Corps valiantly but unsuccessfully engaged the bivouacked Prussian troops at Frohnhoffen on 13 July. The next day, a mixed force from VIII. Corps put up a farcical defence of Aschaffenburg, prompting the Prussian General von Falckenstein to report to his king that "the lands north of the Main [River] lie at the feet of Your Majesty." 46

What is remarkable about these skirmishes is their insignificance. In contrast to the rapid, destructive, irresistible advances of Prussian forces in Bohemia, West Army remained measured in its actions. Kissingen, Hammelburg and Aschaffenburg were objectives only because of their status as railway hubs. Depriving the Bavarians of these hubs limited their ability to shunt their theoretically large army into more dangerous offensive positions. Falckenstein therefore fought a holding action along an east-west line, containing the south German forces rather than destroying them. It was certainly within the powers of the Prussian leadership to sweep their powerful and victorious armies into Stuttgart, Munich and Karlsruhe, especially after the defeat of the Austrian army at Königgrätz had released the Prussian forces there for other duties. Bismarck, however, took no further action against the southern states, but for one or two minor skirmishes to hold their respective armies in place. This lack of action suggests an objective other than conquest.

\footnotetext{
44 Margaret Sterne, “The End of the Free City of Frankfort”, Journal of Modern History 30, 3 (September 1958), 207.

45 Dennis E. Showalter, Railroads and Rifles, 138.

46 Heinrich Friedjung, Der Kampf um die Vorherrschaft in Deutschland, 2.Bd. (Stuttgart: J.G. Cotta'sche Buchhandlung, 1917), 451.
} 
So, too, does Bismarck's involvement in ceasefire negotiations. On 5 July, Bismarck was informed by telegram that France would be willing to act as mediator in peace talks. ${ }^{47}$ The suggestion came to the Prussians via Foreign Minister Drouyn, a champion of the rights of the southern German states who had castigated Wendland for Bavaria not coming to the assistance of the Hanoverians at Langensalza. Drouyn had also spoken with Wendland about the importance to south Germany that Bavaria be represented at the conference. Here, then, was an implicit French endorsement of the southern states in general, and Bavaria in particular. This was not an aberration; as we have seen, a similar suggestion had been made to Wächter months before by Damrémont. This time, it cannot have escaped the notice of either Goltz or Bismarck. ${ }^{48}$ Regardless, the French had not before threatened to intervene in Germany if the sovereignty of the southern states was breached, nor did it imply any threat at this point. The option was still available for the Prussians to ignore Drouyn's olive branch and take the rest of Germany by force. Instead, Bismarck accepted.

\section{The Belated Rise and Fall of Third Germany.}

Varnbüler and Pfordten had planned and fought their 1866 campaigns on the assumption that a long, protracted war would benefit plans for an independent, regional federation. Instead, though the Austro-Prussian War lasted only a matter of weeks, the immediate consequences for southern Germany appeared to be that very federation, thanks to French diplomatic intervention. In a telegram to the Bavarian King Ludwig II, Wendland outlined Drouyn's proposals for lasting German peace. In particular, Drouyn insisted that Prussia guarantee the integrity of Austria (with the exception of Venetia, which was to be ceded to the French, who would then give the region to Italy). On Vienna's part, Austria was to be

\footnotetext{
${ }^{47}$ Robert von der Goltz to Bismarck, Paris, 5 July 1866, in Die Rheinpolitik Kaiser Napoleons III., 1.Bd., 304. 48 Wendland to King Ludwig II. von Wittelsbach, Paris, 9 July 1866, in ibid., 325.
} 
excluded from German affairs. The new political boundaries, however, were more immediately pertinent. According to the French delegation, Prussia, having legitimately occupied many of the northern states by military necessity, could form a union of these states, under Prussian leadership, down to the Main River. Beyond that, however, would be a "union of southern Germany under Bavaria, [with] a completely independent international position to that of the north." ${ }^{49}$ Given the traditional interpretation of the Austro-Prussian War as a Prussian push to dominate all Germany, it would have been inconceivable for Prussia to accept these terms if it indeed wished to incorporate the southern states. Goltz and Bismarck, however, seem to have been amenable to the French proposal. "We must use a certain degree of tact", Goltz wrote,

to avoid the dismemberment of Germany into two completely separate but similar parts, reawakening memories of the Rhenish Confederation. Also, for the time being we must avoid any remark that contains a renunciation of the idea of German unity, for if peace were not to last, we would possibly be forced to appeal to the latter and enact its full implementation. 50

For Goltz the primary concern was to maintain cordial relations between Prussia and south Germany. Unification, however, was not the aim. Rather, it was an option, possibly to be used if Prussia (or Germany as a whole) found itself in danger of war. Thus, even though Napoleon III's government "places significant worth on the right of south Germany, as an independent group of states, to be able to forge its own alliances and fight its own wars, in which north Germany would not be involved", Goltz did not find anything incompatible with Prussia's own aims and aspirations. In fact, Prussia's one objection was not to the creation of this southern federation. Rather, Bismarck and Goltz queried whether or not the agreement would allow for a future unification between Austria and south Germany.

\footnotetext{
49 Wendland to King Ludwig II, Paris, 14 July 1866, in ibid., 350.

50 Goltz to Bismarck, Paris, 14 July 1866, in ibid, 353.
} 
Having been assured by Napoleon III that "the emperor himself does not wish for such a combination", Goltz was happy to accept the Südbund as a fait accompli.51 In any event, the Prussian government's annexations in the north resulted in the convening of a new political union, since the German Confederation was now defunct. As the French had insisted, and Berlin had been happy to agree, this new North German Confederation extended only as far as the Main. However, Bismarck indicated that, if they so wished, any of the autonomous south German states could seek membership in the new union. ${ }^{52}$

Encouraged by Paris, the southern states found themselves, for all intents and purposes, united under Bavarian stewardship. This arrangement was not without its benefits. Varnbüler noted to Pfordten during negotiations with the North German Confederation in Berlin in August that the Prussian leadership was increasingly unlikely to "mistreat Bavaria and consequently repel the south." 53 As the most powerful of the southern Mittelstaaten, Bavaria held a military, political and economic weight that Württemberg or Baden could not match, and that weight, to the relief of a grateful Varnbüler, allowed the southern states to escape severe punishment for their roles in the war. Naturally, there were reparations to pay, but these were relatively mild. Stuttgart was billed for an indemnity of some 8,000,000 fl., and required to withdraw its occupation forces from the junior Hohenzollern principalities to the south, which it had bloodlessly invaded for defensive reasons in the early stages of the war. ${ }^{54}$ Even so, these hardly placed the southern states at any significant disadvantage. Buoyed by the leniency of the peace

\footnotetext{
51 Ibid., 353.

52 Prussia only formally annexed Schleswig, Holstein, Hesse-Kassel, Frankfurt and Hanover. However, twentytwo other states joined the North German Confederation, either of their own free will or through the influence of Berlin. Brendan Simms, Europe: The Struggle for Supremacy, 234.

53 Pfordten to King Ludwig II. von Wittelsbach, Berlin, 13 August 1866, in Die Rheinpolitik Kaiser Napoleons III. von 1863 bis 1870 und der Ursprung des Krieges von 1870/71, ed. Hermann Oncken, 2.Bd.: Juli 1866 bis Juli 1868 (Stuttgart: Deutsche Verlags-Anstalt, 1926), 67.

54 Wolfgang Menzel, Der Deutsche Krieg im Jahr 1866, 69; Robert von Blumenthal to Bismarck, Sigmaringen, 14 August 1866. GStAPK III. HA I, Nr.4439; Blumenthal to Bismarck, Sigmaringen, 29 October 1866. GStAPK III. HA I, Nr.4439.
} 
terms, and encouraged by the French and Prussian acceptance of their regionalist bloc, the governments in Munich, Stuttgart and Karlsruhe moved quickly to formalise the arrangement. In mid-August 1866, a constitution for the new union, tentatively called the Federation of the United States of South Germany, was drafted in Augsburg, indicating that the respective representatives of these governments made some progress towards codifying a set of federative laws. ${ }^{55}$ These laws reflected a developing unitarian south German political identity. The members of this Südbund were not the only ones to acknowledge this changing identity. Indeed, the North German Confederation officially saw south Germany as a single confederation of states, with which it coexisted. The constitution of the North German Confederation explicitly noted that the Confederation would follow a unified and consistent policy with regards "the south German states" — not Württemberg, Bavaria and Baden separately, but as a consolidated political union. ${ }^{56}$

However, the Third Germany that resulted from the 1866 war was also quite different from that envisaged in the 1820 s, or in 1859 . Both Saxony and the northern province of Hesse-Darmstadt, though not officially annexed, were compelled to become part of the North German Confederation. This precluded their involvement in the proposed Federation of United States. Domestically, the Südbund also faced stiff opposition from both the press and the public who, being for the most part unaware of the prewar manoeuvring of the southern governments, were understandably confused and frustrated by the events that followed. Hildegard von Spitzemberg, living in Berlin and therefore not in direct contact with her father at this crucial time, was livid that "peace has been achieved at our expense." Although she acknowledged that Bismarck had dealt with Württemberg fairly, she also believed that Austria, in making the peace at Nikolsburg, had

\footnotetext{
55 Linden to Varnbüler, Augsburg, 11 August 1866. HStAS.E40/72 Bü.443; Verfassung des Bundes der vereinigten Staaten Süddeutschlands. HStAS.E40/72 Bü.443.

56 Großherzoglich Mecklenburg-Strelischer Offizieller Anzeiger für Gesetzgebung und Staatsverwaltung, No.10, 28 June 1867. PAdAA IAAb 88/R641 Nr.11584.
} 
cut the southern states adrift, to fend for themselves at the mercy of the whims and caprices of the victorious Prussians. ${ }^{57}$ Hers was a significantly more moderate reaction than the norm. Elsewhere, the Württemberg population raged at what was seen as a humiliating defeat perpetrated by cowardly and incompetent leaders, who had in turn bartered away Württemberg's sovereignty to Bavaria. Even before the peace was signed, whispers of conspiracy and incompetence had pervaded the public sentiment. Many simply could not understand how the Austrians, with the support of Württemberg and its Mittelstaaten neighbours, had managed to lose to Prussia. "All appears to be confusion, depression, disappointment and especially great and doubtless well grounded dissatisfaction”, George Gordon wrote to London on 18 July. Among the most damaging rumours circulating in Stuttgart, he reported, was that "the inactivity of the 8th Federal Corps and especially the damaging inefficiency of the 7th, or Bavarian Corps" was the result of "treacherous conduct." In this case, the rumours were quite correct; both VII and VIII Corps had remained mostly dormant throughout the war as a deliberate ploy by the south German states to avoid confrontation with the Prussians. Unaware of the Third German rationale behind this "inactivity", though, the Württemberg public reacted with "discontent and discouragement." 58

At the time that Gordon was writing to Whitehall, the Württembergers largely limited their ire to the other southern states, perhaps concluding that their own government could not be party to the suspected perfidy. Therefore, anger was directed towards Prince Alexander, who evidently had not acquitted himself well as VIII Corps commander, as well as Prince Wilhelm, the commander of the Badenese contingent, and Pfordten, whose "doubtful Policy" was seen to be the cause of VII Corp's apparent paralysis. The gravest criticism directed against the Württemberg contingent, by comparison, was

\footnotetext{
${ }^{57}$ Hilegard von Spitzemberg, Tagebuch, 19 August 1866, 72.

58 Gordon to Lord Edward Henry Stanley, No.8, Stuttgart, 18 July 1866. in British Envoys to Germany, 1816-1866, Vol.IV, 391.
} 
that its movements had been shrouded in "inexplicable secrecy." sentiments did not die down. In fact, suspicion now fell on Varnbüler and his ministers. There were calls for an inquiry into the conduct of the Württemberg army, but the resulting report, a handwritten document of 143 pages compiled by the Quartermaster General, contained nothing regarding the political subtext behind Stuttgart's involvement in the 1866 campaigns. Its conclusions were uncomplimentary: Württemberg's mobilisation had been unconscionably slow, its deployment inept, and its contribution to the war effort negligible. ${ }^{60}$ The Beobachter, whose editors held großdeutsch sympathies, was particularly aggrieved that Württemberg had let down the Habsburg monarchy. Lieutenant-General Oskar von Hardegg, the minister of war, was pilloried as "the hero, [...] who lost his head but found an Order of Merit", while Varnbüler was castigated as a "compromised and opportunistic man."61

And where had this opportunism led? Apparently, not to economic prosperity. The spread of the North German Confederation to the Main in fact placed the Südbund at a significant demographic and economic disadvantage. With just the three core states, plus the essentially insignificant southern tip of Hesse-Darmstadt, the Federation would have no more than nine million people, a far cry from the twenty-eight million of the North German Confederation. ${ }^{62}$ The North German Confederation also enjoyed extensive transport opportunities. Northern states had been much faster to connect their cities and industrial centres to sprawling rail networks, an advantage lacking in the south. More to the point, Prussia's occupation of Frankfurt placed in its possession Germany's southernmost

\footnotetext{
59 Ibid., 391.

60 Eduard von Kallee, "Ueber den Anteil des württembergischen Truppenkorps, der 1ten. Division des 8ten. Bundesarmeekorps, von dem Kriege gegen Preußen, besonders die Führung betreffend.” HStAS.E271c Bü.916. For the multiple petitions from the public and press that led to this report, see HStAS.E271c Bü.915.

${ }^{61}$ Der Beobachter, No.66, 20 March 1867. HStAS.E70f Bü.164.

62 Wendland to King Ludwig II von Wittelsbach, Paris, 14 July 1866, in Die Rheinpolitik Kaiser Napoleons III., 1.Bd., 350.
} 
inland port. Coupled with other river ports such as Bremen and Magdeburg, as well as the deep-water harbours of Kiel, Lübeck and particularly Hamburg, the North German Confederation now controlled all of Germany's maritime trade. Rapidly a pronounced economic disparity between north and south manifested, which was evident to all but the most blind observers. As early as August 1866 a deputation in Munich presented a petition to the Landtag, arguing that Bavaria should come to an agreement with Bismarck, so as to enter the North German Confederation. Among other arguments, the petition claimed that the North German Confederation would necessitate a reorganisation of the Zollverein that would benefit the north; since Bavaria could not afford to leave the Zollverein, its best interests would be served in tying itself to the north.63 The petition failed, but its key assumptions were not far wrong. The North German Confederation soon proved to be a robust economic powerhouse. Private enterprise and heavy industry made up the lion's share of the north's prosperity. Throughout 1866, 1867 and 1868 Berlin attempted diplomatically to head off any attempt by Austria and France to create their own "Catholic economic league" that might rival the Zollverein; this was all very well and good politically, but northern industrialists insisted that it should not impinge on their ability to invest and take part in Austria's massive rail reforms that followed in the aftermath of its defeat in the Austro-Prussian War. ${ }^{64}$ This extraordinary confidence of industry was only matched by the ambitions of the political leadership. Trade treaties were established between the North German Confederation and far-flung countries throughout the world: Spain, the Philippines, Cuba, Puerto Rico, Japan, Tonga, Mexico, El Salvador. ${ }^{65}$ It is a measure of the north's economic and political might that its trade aspirations extended so far, when previously German states were largely content to trade amongst one another or their

\footnotetext{
${ }^{63}$ Henry Francis Howard to Edward Henry Stanley, No.65, Munich, 21 August 1866, in British Envoys to Germany, 1816-1866, Vol.IV, 445-446.

${ }^{64}$ Wilhelm Treue, Wirtschafts- und Technikgeschichte Preußens (Berlin: Walter de Gruyter, 1984), 487.

${ }^{65}$ Ibid., 487.
} 
immediate neighbours. Similarly, state debt was all but non-existent; by 1871 , when it was dissolved, the North German Confederation had amassed a debt of 220,000,000 fl., but this was repaid in full by the very next year. ${ }^{66}$

All this amounted to a financial and commercial dominance that the south German states simply could not match. In February 1868, a Prussian memorandum to Bismarck stated that "it must by now be clear to [the south German governments] that every salutary reform undertaken in the areas of the North German Confederation provide for the subjects of the latter an economic superiority over those undertaken for the benefit of the subjects of the South German states."67 The north's advantages — or, rather, the south's disadvantages - could not be ameliorated by reforms or policy changes. By its very nature, the North German Confederation held all the economic cards.

Certainly, the economic backwardness of the south was clear to the southern governments as well as the newspapers, with their ever more critical and, sometimes, hysterical editorials. Julius Fröbel, now the editor and proprietor of a regional south German newspaper, the Süddeutsche Presse, commented that "the formation of a south German federation has not succeeded, and has - so far as a truly federative design is concerned - even less chance of succeeding in the future." ${ }^{68}$ Fröbel's most severe objection to the Federation was not, however, the economic failings, but the political. To Fröbel, the Third German experiment was doomed to fail because Württemberg and Baden had been marginalised by Bavaria, "whose political importance has been increased by the failure of the south German federal plans." ${ }^{69}$ Bavaria was the most powerful of the southern states;

\footnotetext{
${ }^{66}$ This is especially astonishing, given that much of this debt was raised through the fighting of the FrancoPrussian War of 1870 to 1871 . Moreover, even though, by this state, Germany had been united, the North German Confederation's debt was paid without being subsidised by the southern states in any way. Adolph Wagner, "The National Debt of the German Empire", The North American Review 174, 547 (June 1902), 845-846.

${ }^{67}$ Gustav Dietrich and Alexander von Sybel to Bismarck, Berlin, 28 February 1868. BArch.R/1401/1524.

${ }^{68}$ Julius Fröbel, “Circular”, 1 October 1867. HStAS.E40/72 Bü.442.

${ }^{69}$ Ibid.
} 
this had, after all, been the reason that Drouyn had approached Wendland, and not Wächter, in June 1866. From Fröbel's estimations, Stuttgart and Karlsruhe had merely traded domination by Berlin for domination by Munich. The proposed constitution suggested that Bavaria, with six out of a total of fifteen seats in the (still hypothetical) southern parliament, carried more political clout than the other members.

If anything, however, Bavaria seems to have become convinced that administering a Third German bloc was a far too difficult task for Munich to manage. Such is reflected in the Bavarian leadership. Pfordten, who had been so enthusiastic in pursuit of a Südbund agreement, resigned in December 1866. In his place stepped Prince Chlodwig von Hohenlohe, a moderate liberal-nationalist, whose personable nature was nevertheless far less proactive than that of his predecessor. Where Pfordten had negotiated through Wendland for Bavaria to take the reins in south Germany, Hohenlohe was content to allow his opposite numbers in Stuttgart and Karlsruhe to follow their own paths. Thus, while the relationship between Württemberg and Bavaria strengthened following the war, this was not, as Fröbel feared, at the expense of Stuttgart's autonomy.

Even if Hohenlohe did have aspirations to lead the Südbund, events quickly demonstrated south Germany's shortcomings. French rumblings over the territory of Luxembourg, nestled on the westernmost Prussian border and within an uncomfortably close proximity to the Bavarian Palatinate, compelled both Hohenlohe and Varnbüler to reassess their military policies. On 15 May 1867 Varnbüler wired Hohenlohe a suggestion that Württemberg and Bavaria should formalise a military defence treaty for the "protection of the many powers of the South German States." By the very next day, that treaty had become a reality, and immediately thereafter, Varnbüler contacted Spitzemberg in Berlin to sound out the possibility of Prussian acceptance. ${ }^{70}$ Baden's panicked response

\footnotetext{
70 Varnbüler to Prince Chlodwig von Hohenlohe, Stuttgart, 15 May 1867. HStAS.E40/72 Bü.442. Varnbüler to Baron Karl Hugo von Spitzemberg, Stuttgart, 16 May 1867. HStAS.E40/72 Bü.442.
} 
to fears of yet another French war was even more radical. Not only did Karlsruhe urgently request that their army be "Prussianised" - that is, the command, training and supply structures reformed along Prussian lines, with Berlin's assistance - but the grand duchy also considered leaving the southern bloc to join the North German Confederation. ${ }^{71}$ As with many of the Franco-German war scares of the nineteenth century, the Luxembourg crisis soon passed, but its consequences were considerable. Fröbel clarified the problem: "The recent danger of war between Germany and France, which, thank God, seems to have fortunately run its course, has uncovered for all to see our need for help, and has vividly demonstrated the concerns of an unclear and unfinished relationship between the southern states and the north." 72 The threat was that a war with France would immediately endanger not just Baden, Württemberg and Bavaria, but indeed all of Germany. It was clear to Fröbel, and indeed to Varnbüler and the Badenese and Bavarian governments, that none of the south German states, nor even the southern states standing united, could negate that threat.

In any practical sense the south German project had failed by May 1867. Domestic opposition to the supposed predominance of Bavaria in the proposed Federation of United States of South German States bears some responsibility for this. While some segments of the press and the citizenry were enthusiastic about the advent of Third Germany, others distrusted Munich's intentions. Worse, the practical considerations rapidly showed the Südbund to be an economic minnow in comparison to its much larger and more richlyendowed northern neighbour. Nor could it project the same degree of might and power that the North German Confederation could. Whether they stood on their own or together in a bloc, the Mittelstaaten simply did not have the military force nor geopolitical presence to secure their own existence without the help of a protective patron. In the case of the Luxembourg Crisis, that patron was Bismarck and the North German

\footnotetext{
71 Spitzemberg to Varnbüler, Berlin, 13 May 1867. HStAS.E40/72 Bü.442. Spitzemberg to Varnbüler, Berlin, 18 May 1867. HStAS.E40/72 Bü.442.

${ }^{72}$ Julius Fröbel, “Circular”, 1 October 1867. HStAS.E40/72 Bü.442.
} 
Confederation. The next logical step, given the inevitable failure of the southern experiment, would have been for Württemberg and its neighbours to dissolve their federation before it had actually been formed, and to join the North German Confederation. This possibility had been mooted early on by the Bavarians, who had recognised their state's weakness. The Prussians were certainly not averse to turning their northern alliance into a more general German bloc. A pamphlet written by the Hanoverian diplomat Georg Münster von Derneburg in 1868 put the problem into clear perspective, while at the same time repeating the position Bismarck had taken in 1866: the Federation of the United States of South Germany offered little or nothing to its constituents, Derneburg claimed, and the only objections the south German governments could have to a closer relationship with the north were either based in religion (since the south was largely Catholic, and the north mostly Protestant) or else a hope to create a south German republic similar to that of Switzerland. The people who believed that these were achievable goals were "dreamers, sleepwalkers."73 If southern Germany did not wish to become "the prey of foreigners", Derneburg continued, its only option was to approach and join the North German Confederation of its own free will. ${ }^{4}$

So, at least, goes the reasoning. But Prussia had been an unknown quantity for decades, and to many its intentions were still inscrutable. Third Germany had often been the preferred hypothetical model for German nationhood among the southern Mittelstaaten. It is also true that, at this crucial juncture, Württemberg was gripped by human survival instinct on a state scale. Its hard-won sovereignty was jealously guarded by its political masters, its citizens and its newsmen. As a result, for the next four years the illusion of the Südbund regularly interchanged with the equally spurious illusion of

\footnotetext{
73 Georg Herbert Münster von Derneburg, Der norddeutsche Bund und dessen Übergang zu einem deutschen Reiche (Leipzig: Brockhaus, 1868), 43.

${ }^{74} \mathrm{Ibid}$., 39-40.
} 
independence, but this illusion was continually undermined by the growing closeness of the southern states to Prussia.

It has been suggested that the influence of Prussia on the would-be Südbund in the latter years of the 1860s was an encroachment dictated by Berlin, and much has been made of the so-called Schutz- und Trutzbündnis, a military agreement between Bavaria and Prussia (and, by extension, the other south German powers) of 22 August 1866. To many observers, contemporary or otherwise, this agreement was nothing short of bargaining away the independence of movement of the southern states, tying them into "eternal offensive-defensive treaties" that placed the Mittelstaaten well within Prussia's sphere of influence and made their nominal independence all but moot. ${ }^{75}$ When the alliance was made public in April 1867, a significant proportion of the southern press and populations were outraged. But once more, we should be cautious not to ascribe too much significance to this development. For one, the title of the treaty is somewhat misleading. The German word Trutz can carry a connotation of preemption. Schutz, however, is more correctly indicative of protection, rather than attack; more importantly, the text of the treaty itself mentions nothing of an offensive nature, but rather a guarantee to safeguard the integrity of the southern and northern states in the event of war. ${ }^{76}$

In any case, the supposedly explosive Schutz- und Trutzbündnis represents no significant departure from the state of affairs that had existed between the constituent members of the German Confederation prior to 1866 . Moreover, the treaty itself was a measured and intelligent reaction from the southern governments, given their own lack of

\footnotetext{
75 Paul W. Schroeder contends that the Bündnis ended the military autonomy of the southern states. However, from a purely political standpoint, the states themselves retained their sovereignty. Christopher Clark, Iron Kingdom, 547; Paul W. Schroeder, "The Lost Intermediaries: The Impact of 1870 on the European System", The International History Review 6, 1 (February 1984), 19; Abigail Green, Fatherlands, 59.

76 Schutz- und Trutzbündnisvertrag zwischen Preußen und Bayern, 22 August 1866, in Ludwig Hahn, Der Krieg Deutschlands gegen Frankreich und die Gründung des Deutschen Kaiserreichs. Die Deutsche Politik 1867 bis 1871 (Berlin: Verlag Wilhelm Herz, 1871), xiv ff.; Friedens- und Bündnisvertrag zwischen Preußen und Württemberg, Berlin, 13 August 1866. GStAPK III. HA MdA, I. Nr.4440.
} 
military power and their ever-present fear of foreign aggression. Just how pervasive this fear was can be seen in the various communiques between the diplomats and government figures. As early as 10 May 1867, even before Hohenlohe and Varnbüler sent telegrams to one another over the Luxembourg Crisis, the Bavarian minister-president was discussing the possibilities of a Prussian-Austrian-Bavarian coalition to defend against the seemingly inevitable aggression of France. ${ }^{77}$ By December, Württemberg's ambassador in Vienna sent a series of alarming telegrams to Stuttgart, warning of possible Russian designs on Germany. ${ }^{78}$ At the same time, if the Austro-Prussian War had not clarified that Austria was incapable of acting as the defender of Germany, Varnbüler's agents had delivered him a report indicating that Austria, bankrupted by the war and its own economic stagnation, would spend the next indefinite period of time focusing on internal strife. As a result, Austria would be in no position at all to come to the aid of the southern states against France or Russia, even if Franz Joseph wished to and even if the peace treaty that had ended the Austro-Prussian War had permitted Austrian intervention. ${ }^{79}$ In this instance, it was natural, predictable and arguably vital that the southern states gravitated closer to Prussia, for the circumstances that had almost accidentally delivered the Südbund its very chance of existence had also left it weak and in an unfavourable economic and political position. With Baden independently investigating the option of joining the North German Confederation, it was left to Hohenlohe to clarify the Bavarian and Württemberg position. Both the southern governments, he insisted publicly, were committed to fostering a strong and binding relationship with the North German Confederation..$^{80}$

\footnotetext{
77 Baron Max Pergler von Perglas to Hohenlohe, Paris, 10 May 1867, in Die Rheinpolitik Kaiser Napoleons III., 2.Bd., 387-389.

78 The reason for this concern is unclear, but may be a reflection of the uncertainty and unrest in the political circles of St. Petersburg at the time. Thumb von Neuburg to Varnbüler, Vienna, 20 December 1867. HStAS.E40/72 Bü.442; W. Bruce Lincoln, "Reform and Reaction in Russia: A.V. Golovnin's Critique of the 1860s", Cahiers du Monde russe et soviétique 16, 2 (April - June 1975), 172.

79 Ow to Varnbüler, Vienna, 22 May 1867. HStAS.E40/72 Bü.442.

${ }^{80}$ Norddeutsche Allgemeine Zeitung, 17 October 1867. HStAS.E40/72 Bü.442.
} 
This is not to say that a Württemberg-Prussian rapprochement was initially a popular move. Far from it; the initial public reaction to Prussian approaches to Stuttgart (or viceversa) was one of resentment, fear and hostility. The content of the military treaty with Prussia was innocuous enough, but the perception of it as a dissolution of Württemberg's military sovereignty caused vehement protests once it became public in April 1867. The Württemberg Volkspartei, a großdeutsch-inclined political party, had previously rejected the Südbund on the grounds that it was backed by the French, and therefore could encourage French influence in Germany. ${ }^{81}$ Now, the party organised a petition calling on King Karl and Varnbüler to reject the Bündnis and any attempts to reform the army based on the Prussian model. The efforts of the pollsters garnered some 150,000 signatures, a considerable number that constituted nearly the entirety of the state's electoral suffrage. In January 1868 another petition, organised by the Volkspartei deputy Karl Mayer, collected 27,000 signatures in just a fortnight. ${ }^{82}$ Perhaps even more devastatingly, the Württemberg elections to the Prussian-convened Customs Parliament of 1868 returned no victories for pro-Prussian candidates. On the contrary, it was the Volkspartei that made the most gains, and many of its leading members had been advocating Württemberg's withdrawal from the Zollverein since the beginning of 1867.83

These events, however, should not be taken as a blanket rejection of Prussia, but rather as the response of a confused and fearful public. The Volkspartei petition was not a rally of support for an Austrian-led model of Germany, but a protest against what was seen as a capitulation by an incompetent government to Berlin. In the gloomy afterglow of defeat, it was to be expected that the Württembergers reacted badly to anything pro-

\footnotetext{
${ }^{81}$ Gerlinde Runge, Die Volkspartei in Württemberg, 127.

82 Der Beobachter, Nr.25, 31 January 1868.

83 The argument to withdraw from the Zollverein was not shared by all the Volkspartei members, however. Even for those who strongly believed that the Zollverein offered Württemberg no advantages, such as Moriz Mohl and Carl Deffner, the caveat was always that Württemberg should not act unilaterally. That is to say, Württemberg should withdraw from the Zollverein if (and only if) other states (particularly Bavaria and Baden) also withdrew. Abigail Green, Fatherlands, 59; Gerlinde Runge, Die Volkspartei in Württemberg, 130-140.
} 
Prussian in nature, especially when the policies were to be enacted by the government of the "compromised and opportunistic" state minister. Similarly, the Customs Parliament elections, while stunning insofar that Württemberg was the only state not to return a proPrussian member, were nothing more than a curious anomaly. In the domestic elections to the Landtag of the same year, delegates from the Deutsche Partei (often referred to as the "Prussia Party" by its detractors) enjoyed more favourable results, though the Volkspartei still had a clear majority; by the time the votes were counted, the Volkspartei claimed twenty-three seats, compared to fourteen for the Deutsche Partei. ${ }^{84}$

In spite of its defeat at the polls, the pro-Prussian Deutsche Partei still had a strong showing - far stronger than the elections for the Customs Parliament just two and a half months earlier would have suggested. In part, this was due to the disunited nature of the opposition to Prussia. By and large, it was the politically-inclined Catholics, who had maintained a vested interest in Großdeutschland, who resisted what they saw as the encroachment of Protestant Prussian politics, and particularly the politics of the antiCatholic Bismarck. ${ }^{85}$ But Bismarck was resisted by Catholics even within his own state. Bills put before the Prussian Landtag by the minister-president were routinely voted against by the Catholics of the Centre Party, for instance. However, Catholicism represented only a minority, albeit a sizeable one, within the proportionately Lutheran Kingdom of Württemberg. ${ }^{86}$ In any event, this Catholic resistance was hardly uniform in scope. Bavaria was the state with the largest Catholic population of all, but Hohenlohe, himself a devout Catholic, was not uniformly hostile to Prussian intentions.

The sum total of these experiences was a certain sense of inevitability. The Federation of the United States of South Germany was little more than an optimistic fiction, and there

\footnotetext{
${ }^{84}$ Gerlinde Runge, Die Volkspartei in Württemberg, 148.

85 As Runge points out, in many overwhelmingly Catholic electorates, the Deutsche Partei did not even field a candidate. Ibid., 148-149.

${ }^{86}$ Koppel S. Pinson, Modern Germany: Its History and Civilisation (New York: Macmillan, 1961), 140-141.
} 
is a striking contrast between the editorial desires of the more firebrand press outlets, and the actions of the informed political apparatus of the southern states. Baden's Karlsruher Zeitung decried the possibility of closer relations between south and north as "nothing more than the continuation of the circumstances already created by the extant treaties of alliance with Prussia, which are unsustainable in the long run." 87 Precisely why the treaties with Prussia were unsustainable was not discussed, but given the Karlsruher Zeitung's past overt displays of Badenese and south German particularism, it is safe to assume that the Prussian approaches were dismissed out of hand simply because they did not appeal to the editors' paradigm of Badenese independence. ${ }^{88}$ Württemberg's Beobachter, unfriendly to the Varnbüler ministry at the best of times, was even less grounded in reality. In its own editorial in March 1868, it implored the Volkspartei to fight to "prolong the Südbund [because] the Südbund is for us not simply a guarantee of individual independence from Prussia, but it is also a guarantee of a reunification of Austria and Prussia, into a single Germany that contains them both." ${ }^{\prime} 9$ This reunification of the great powers was by this stage a political impossibility, one that even the Karlsruber Zeitung had dismissed as "questionable"; the Beobachter's increasingly desperate calls to halt the "eternal separation of German Austria from Prussianised Germany” were the last gasps of Württemberg-based Greater Germanism.

While some sectors of the press and the political parties remained friendly to Vienna, in the southern halls of power pro-Austrian sentiment had all but disappeared. Hohenlohe's speech to the Bavarian chamber of deputies in October 1867 made his government's position vis-a-vis Austria and Prussia extremely clear. "We do not want any constitutional

\footnotetext{
${ }^{87}$ Karlsruber Zeitung, 15 October 1867. PAdAA IAAb 92/R662 Nr.11667.

88 The Karlsruher Zeitung had previously, in fact, been very publicly castigated by its chief rival, the Badische Landeszeitung, for its "tender and heartfelt sympathies for the Trias." Badische Landeszeitung, 6 May 1866. HStAS.E70f Bü.164.

${ }^{89}$ Der Beobachter, No.60, 12 March 1868. HStAS.E70f Bü.164.
} 
relationship of the southern states under the leadership of Austria", he declared to the Landtag. At the same time, he sounded the death knell for Third Germany, and preempted the likelihood of unification under Prussian stewardship. Bavaria, he insisted, would not enter the North German Confederation. It would, however, do so in conjunction with its southern neighbours, because autonomous action in this regard could only be damaging to the national cause. "We do not want a south German federal state", he continued; "gentlemen, I do not speak for a unification of Bavaria with the North German Confederation, I speak for a unification of the south German states [with the north.] The national border, which is drawn between us and the North German Confederation, must surround all of the south. Only in this form is [unification] tolerable and achievable." Hohenlohe left his parliament in little doubt of the course of action to follow. "There remains no other path available to the State Government", he said, "but to work towards the reunification of Germany, with recognisance of the existing circumstances."90 Coupled with his earlier insistence that south and north Germany would work closely together, Hohenlohe's speech was effectively a declaration that Bavaria was now willing to guide the Federation states towards a unification with the North German Confederation.

Hohenlohe's appeal for all the south German states to work towards the common good of unification found a receptive audience in the Neues Schloß in Stuttgart, and profound alarm in Paris. A rumour that Württemberg's King Karl had sent a letter "replete with protestations of fidelity and commitment to the Prussian government" had several Parisian periodicals scrambling to assure readers that such a letter did not exist, and that the Württemberg government, which had in the past been at least amicable towards France, would never consider cooperating with Prussia more than was strictly necessary. Writing in La France, however, the noted jurist Paul Pradier-Fodéré was forced to admit that "certainly

90 Hohenlohe, Address to Abgeordnetenkammer, 8 October 1867, in Ludwig Hahn, Der Krieg Deutschlands, 230-235. 
Baron de Vambüler [sic.] [...], in [his] speeches, has not ceased to proclaim his government's fealty [to Prussia]."91 By December, the French press had decided that south Germany had betrayed its Parisian allies. "The Duchy of Baden is Prussian, the Grand Duchy of Hesse is Prussian, and Bavaria, continuing its rapprochement with Prussia while turning its back on France, has advised its young king to find a woman in St. Petersburg, via Berlin”, La Gazette de France complained (and which Wächter obediently reported to Varnbüler). "Württemberg is not to be outdone by its neighbours, in a rivalry that must bring joy to Mr. Bismarck." 92 To the French, deeply concerned by the possibility of a rising German power that would rival their own European position, the southern states were duplicitously falling over themselves in their attempts to please the Prussian puppet-master, Bismarck.

Even this is not altogether fair. As we have seen, the Württemberg attitude towards Prussia had never been uniformly hostile, and there had always been some segments of society that had favoured a Germany captained by Berlin. By the late 1860 s, all other options for German unification had run their course. The Beobachter's ridiculous appeals to the Volkspartei aside, hardly anyone in Germany or even Austria saw Austrian involvement in Germany as a realistic possibility. Third Germany was untenable even before it had become a reality. The Südbund was too weak economically, politically, and militarily to survive without a patron, and with widespread fears of French (and, occasionally, Russian) designs on Germany, that patron could only be the North German Confederation itself. By 1868 Stuttgart had committed itself to a course that could only result in unification under the guidance and leadership of Berlin.

\footnotetext{
91 La France, 14 July 1868. HStAS.E50/12 Bü.143; Le Mémorial Diplomatique, No.29, 16 July 1868. HStAS.E50/12 Bü.143.

${ }^{92}$ La Gazette de France, 31 December 1868. HStAS.E50/12 Bü.143.
} 


\section{Endgame.}

In spite of the inevitability of unification, Württemberg maintained its independence for some years after the question became moot. This was not so much due to a desire to maintain that independence, though Varnbüler would not meekly hand over the reins of the state's autonomy to Bismarck without some assurances and compromises, but rather as a result of negotiating the difficult diplomatic and administrative circumstances. The North German Confederation was as new a geopolitical body as the abortive South German Federation, and administrative minutiae aimed at homogenising north German economic, social and agricultural policies were a key priority for the confederal parliament. Consequently, in the years between 1867 and 1870 a raft of policies were introduced to bring Hanover, Hamburg, Mecklenburg and the other north German states into line with Prussia. These included, but were not limited to, measures aimed at coordinating charitable housing, creating a system of weights and measures, and combatting cattle plague. ${ }^{93}$

While these bureaucratic reforms took root in the north, similar preparations were gradually enacted in the south. South German consulates in foreign cities, which had heretofore been operated independently as consulates of Württemberg, Bavaria or Baden, slowly began to merge. By January 1869, two pan-German consulates operated in the United States, while Württemberg maintained some eight further consular offices in conjunction with one or more of its neighbours. ${ }^{94}$ Stuttgart had made it abundantly clear that it wished to cooperate intimately with the North German Confederation for the foreseeable future as early as July 1867 , when it had ratified a treaty tying its economic

\footnotetext{
${ }^{93}$ See BArch.R101/2904/31776.

94 "German" consulates could be found in Baltimore and St. Louis. Württemberg, Baden and Bavaria ran joint consulates in Lyon, Cincinnati, Louisville and Milwaukee, while Württemberg and Baden jointly had consulates in Ostende, Le Havre, Mulhouse and Geneva. Baden and the North German Confederation shared a single consul in Trieste, and Baden and Bavaria cooperated in Liverpool, Philadelphia and New Orleans. Karlsruher Zeitung, 15 January 1869. BArch.R1401/1567.
} 
future to that of the reconstituted Zollverein. ${ }^{95}$ The next year, Varnbüler indicated to Prussia's envoys that Württemberg and its south German companions were keen to further collaborate with Prussia on military matters and foreign affairs. ${ }^{96}$ "The great preoccupation of southern Germany", the French paper La France scoffed, "is to send all their kings and grand dukes to Berlin [where they] stand single-file to show reverence to King Wilhelm."97

Thus, the efforts to closely integrate Württemberg, Bavaria and Baden with the North German Confederation were already well underway by the time a series of domestic outrages in France sparked yet another war scare in 1870. An attempt on Napoleon III's life using "a certain quantity of explosive powder" may not have overly concerned Varnbüler, but Wächter's reports of growing discontent in the French army noticeably increased the frequency of the state minister's negotiations with Bismarck. Perhaps remembering the numerous occasions in which a rebellion in France had sparked violence and revolt in Germany, Varnbüler could not help but fear the increasing number of dispatches reaching him from Paris: public appeals to "our brothers in the army" to resist the emperor, an address to "the radicals and the army" calling for military insurrection, and, most chillingly, an editorial in the periodical La Marseillaise, issuing the old cry of the Revolution: liberté, egalité, fraternité, ou la mort.98

Under these circumstances, less credence should be placed on Varnbüler's insistence the previous year that "Württemberg wants to remain Württemberg as long as it has the power" than his response to a French query in 1870 over which side Württemberg would choose in the event of a war between France and Prussia. Given what appeared to be the

\footnotetext{
95 Report of the United Representatives for Customs and Taxes and for Trade and Transport, Bundesrath Session No.12, BArch.R1401/1567.

${ }^{6}$ August Heinrich Hermann von Dönhoff to Bismarck, No.41, Stuttgart, 10 June 1868. PAdAA IAAb 92/R663 Nr.11673.

${ }^{97}$ La France, 30 April 1870. HStAS.E50/12 Bü.147.

${ }^{9}$ La Presse, 1 May 1870. HStAS.E50/12 Bü.147; Le Peuple Français, 2 May 1870. HStAS.E50/12 Bü.147; La Marseillaise, No.133, 2 May 1870. HStAS.E50/12 Bü.147.
} 
radical destabilisation of the French political scene, and now this suggestion of war, Varnbüler answered in the only way he could. Württemberg would act in accordance with national interests. 99

Württemberg's siding with the North German Confederation was not a question of maintaining the Schutz-und Trutzbündnis, nor of keeping the state in Prussia's good offices, but was, to Varnbüler, a national duty. Therefore, by 1870 , even before the Ems Despatch escalated the sabre-rattling between Berlin and Paris, and well before the first actions of the Franco-Prussian War, Stuttgart had acknowledged that the nation of Germany existed in everything but a binding legal sense. This unification, according to contemporary sources as distinct from one another as the British Foreign Office and the popular American newsmedia, had effectively been completed before war broke out between Germany and France. ${ }^{100}$ That reality was clearly indicated by the words and deeds of the Württemberg state minister.

These acts may have been in the realm of high politics. But, as we have seen, Württemberg politics rarely diverged from the public will. The decision to join in united Germany had already been made by December 1870 ; nevertheless, it was this, and the public enthusiasm for it, that became a decisive issue in the Landtag election campaigns of that month. The Deutsche Partei, which had been denigrated by French observers and by those skeptical of Prussia as the "Prussia Party", demonstrated how important the German Question was, by topping its pamphlets and advertisements with the simple question: "Are you in favour of joining the North German Confederation?" The reaction from the Württemberg voting public was a resounding yes. When the ballots were counted, the

\footnotetext{
99 Geoffrey Wawro, The Franco-Prussian War, 24; Eberhard Naujoks, "Württemberg im diplomatischen Kräftespiel der Reichsgrüngungszeit (1866/70). Zur Problematik der deutschen Politik des Freiherrn von Varnbüler", ZWLG 30 (1971), 234.

100 See, for example, Granville Leveson-Gower, Earl Granville, to Count Albrecht von Bernsdorff, London, 21 October 1870. HStAS.E40/18 Bü.409; C.A. Eggert, “The True Causes of the French-Prussian War”, Putnam's Monthly Magazine of American Literature, Science and Art 16, 34 (October 1870), 451.
} 
Deutsche Partei suddenly found itself in the majority. Meanwhile, the Volkspartei, in spite of the best efforts of its newspaper benefactor, the Beobachter, saw its parliamentary majority shrink to a definite minority; Volkspartei and political Greater Germanists in the Landtag now found themselves with just seventeen seats. ${ }^{101}$ One month later, on 18 January 1871 , King Wilhelm of Prussia was crowned German emperor in a ceremony in the Hall of Mirrors in Versailles - a coronation that met with the conspicuous approval not just of the powerbrokers in Stuttgart, but also the Württemberg population as a whole.

101 Alon Confino, The Nation as a Local Metaphor: Württemberg, Imperial Germany, and National Memory, 1871-1918 (Chapel Hill: University of North Carolina Press, 1997), 21. 


\section{CONCLUSION}

THROUGHOUT THE PRECEDING pages, we have analysed the role that Württemberg played in German unification, and the role German unification played in Württemberg. But what is the significance? We should not lose sight of the fact that this thesis focuses not on the origins of the unification itself, but rather on Württemberg's development and agency during the events of the unification. Nevertheless, perhaps, by looking at the mechanics of the Reichsgründung itself, we can also determine the implications for Württemberg. The prevailing trends and orthodoxy of German historiography have already been identified; if there is a popular explanation for the formation of Germany in 1871 , it is that Prussia used its military strength and the threat of force to coerce the other German states into subjugation. The leadership of the Mittel-and Kleinstaaten was irrelevant to the question, since no state - not Bavaria, not Saxony, not Württemberg - had the political strength to resist. As for the public attitude, while it is possible (or even likely) that many Germans supported some form of unification, their will was also largely irrelevant. This was, as Taylor tells us, conquest rather than unity.

This story, as popular as it is, is wrong. It presumes that the smaller states were entirely impotent (they were not), that Prussia was bent only on conquest within the German hinterland (it was not), that German unification could not be achieved by largely peaceful means (it was), and that Prussian conquest was the only means by which German unification could be achieved (it was not). Bismarck and Moltke were not machiavellian schemers whose chief aim was to sweep through Germany. If they were, and if it was, they would not have stopped at the Main in 1866, when the southern states were ripe for the picking. And, while the Prussia of the 1860s had at its command overwhelming force, it never threatened Bavaria, Baden, and Württemberg, for the simple fact that it never had to. The decision-makers in Munich, Karlsruhe, and Stuttgart may have toyed with other 
options between 1866 and 1871, but in the end they all chose to follow Berlin's lead, and while it may be true that circumstances had made this the only reasonable option left available to them, 'prudence' and 'duress' are two entirely different things.

A key failing of the existing narrative is its reliance on 1866 as the one, significant moment of rupture. Yet, as we have seen, the concept of German unification had been popular well before Prussia settled its grievances with Austria. Indeed, those who had originally agitated for unification in the region, as early as the days of the Napoleonic Wars, were from neither Prussia, nor Austria, but instead hailed from the smaller states.

Of these states, one of the most prominent was Württemberg, by dint of the state's complex relationship with its population and territories. In the immediate aftermath of the wars, Württemberg found itself with a significantly larger population, made up of new subjects whose ties to Stuttgart were weak at best, given their previous affiliations with now-defunct states and imperial enclaves. As a result of this, the nature of Württemberg identity was confused and, due to the reign of an unpopular and authoritarian king, many agitated for a wider, supranational identity, to which all Germans could belong. Upon the death of King Friedrich, and the ascension to the throne of his son Wilhelm, the relationship between subject peoples and the crown quickly stabilised. While Friedrich had been a despot - or, in the words of the Prussian diplomat Stein, a "tyrant or sultan" Wilhelm was a more reform-minded and constitutionally-inclined monarch, who rapidly gained the trust and loyalty of his people. However, this merely increased the drive for unification with the other German states. Wilhelm and his ministers were keenly aware of Württemberg's deficiencies, particularly in the fields of modern, mechanised industry. Their attempts to modernise the country initially failed due to the inertia of the Württemberg Stände, whose interests lay in the continued emphasis on agriculture, rather than mechanisation. Furthermore, since Württemberg lacked the resources vital to industrialisation - particularly coal, but also base metals - even if the Stände had approved a 
massive expenditure on state-driven economic reform, it is unlikely that Württemberg could have achieved much by itself. This placed Württemberg at both a financial and military disadvantage compared to neighbouring countries which were capable of industrialisation, since these competitors could outstrip Württemberg's output of salable goods, could invest in rapid, modern means of transport (such as steam railways), and could manufacture armaments (such as the Dreyse needle-gun) at a vastly superior pace. Wilhelm's response was to look further afield, to cooperate with neighbouring states in order to safeguard his borders and trade on friendly terms to narrow the financial gap. In essence, Wilhelm saw foreign investment and collaboration as the only rational way forward.

These efforts achieved mixed results. Württemberg's championing of a regional customs union solidified its relationship with Bavaria, the largest of the Mittelstaaten; this relationship would prove a fruitful one in later years. But the union itself was a failure, due to the conflicting, particularist interests of the Mittelstaaten, and the inability to come to mutually beneficial agreements. In the military sphere, Württemberg began its own, slow rearmament, but had to rely on a series of negotiated treaties with other, larger powers. This did not sit well with Wilhelm, who did not trust his counterparts (particularly in Vienna or Paris) to recognise and respect Württemberg's sovereignty in the event of war.

These attempts at cooperation continued for much of the first half of the nineteenth century, with varying degrees of success. However, the growth of a nascent, popular, liberalnationalist revolutionary sentiment, particularly in the southern states, fundamentally changed the course of Württemberg's German policy. Even before revolts spontaneously broke out in the German interior in March 1848, Wilhelm had already noted the rise of more radical popular nationalism, and had warned his fellow monarchs, as well as the Austrian general Radetzky, that Germany's salvation from violence and bloodshed lay in unification. Wilhelm's solution seems to have gone well beyond the boundaries of the 
policy of cooperation that he had previously followed; here, he was suggesting close, even federal collaboration between the states. When this did not happen, as he predicted, revolutions broke out in all of the major German centres, including Vienna, Berlin, and Dresden. But it was Stuttgart's willingness to adapt to the popular mood, and the ability of Wilhelm to countenance the founding of a government led by a republican liberal, Friedrich Römer, which spared the Württemberg capital from the same unrest that struck other states.

The revolutionary years, and the abortive experiment of the Frankfurt Parliament, were fatal to the liberal-nationalist character of German unification, but not to the cause of German unity itself. In Württemberg, the unification project took on a new urgency, especially after Württemberg troops were forced by Austria (against the will of the king) to intervene in the Hesse-Kassel emergency. Increasingly in concert with Bavaria, Württemberg strove to unite the Mittelstaaten, arguing once more that the German great powers could not be trusted to act in the best interests of all the German states. This, however, was no longer to be accomplished through merely cooperative measures, as had been largely the intention of the pre-1848 years. Instead, what was being championed by the Württemberg crown was a binding, intimate Bund, a logical progression of Wilhelm's early realisation that Württemberg could no longer be expected to stand alone, coupled with the experience of the revolutions. In a series of diplomatic manoeuvres, Stuttgart attempted to position itself and its fellow southern states, so as to take advantage of confusion amongst the German great powers, and so assert themselves. This initiative was frequently frustrated, though, by disagreements between these potentially constituent states, as well as the short duration of any Austrian or Prussian distractions. After Wilhelm died, the opportunity again presented itself, in the form of the Austro-Prussian War, and this time, through a combination of decisive Bavarian-Württemberg leadership and Prussia’s unwillingness to extend its will further than the Main, the Südbund finally stood on the 
cusp of creation. The very idea of the Bund, however, had been built on a pragmatic foundation of economic and military survival, and in the post-1866 realities, Stuttgart and Munich quickly discovered that their long-awaited federation was no longer viable in either sense. Consequently, through its own initiative, Württemberg approached the Prussian-led North German Confederation, with the aim of joining it. In January 1871, this was accomplished.

Nothing in this suggests that Württemberg was a state that did not control its own fate. On the contrary, Württemberg was often the originator of many of the mooted unification projects throughout the nineteenth century. The state never bargained away its independence because, in the minds of its leaders, the wellbeing of the state was assured by its partnership with its neighbours. It was Württemberg's king who enacted a constitution that subverted Austria's attempts to muzzle German liberal-nationalism. It was Württemberg, in conjunction with Bavaria, that made the first efforts to form a panGerman customs league. In the early 1820 s, King Wilhelm tried to band the southern German states together in order to protect them from Austria's particularist interests; he would take an active role in other attempts to do the same in 1830 and 1831, and in 1847 he took the initiative in trying to convince the other states that German unity would neuter the revolts that were beginning to foment. After the revolutions, once it became apparent that Austria was once more ill-disposed towards German unity, it was Württemberg that facilitated the meeting between the French and Russian emperors that would eventually lead to France going to war with Austria. When Austria and Prussia went to war in 1866, Württemberg - and its frequent partner in crime, Bavaria - actively undermined the Austrian war effort in the hope that the wearing down of the two German great powers would result in the emergence of a federation of south German states, with Württemberg playing an important role in its governance. Finally, when the resulting Federation of the United States of South Germany proved to be unviable, Stuttgart opened negotiations with 
Berlin, and when it sided with Prussia as the latter looked to be approaching war with France, it did so cognisant of the consequences. In 1870 and 1871, Württemberg was not forced to become a component of "Greater Prussia." It chose, willingly and with full agency, to become a constituent state of Germany. This was not a powerless state at the tender mercies of its strong neighbours.

Finally, we have seen much of the personality-driven elements of this history. Indeed, it is tempting to define Württemberg's role in German unification in terms of three phases. The first phase, personified by Friedrich, was dominated by delusions of parochial independence. The second - the Wilhelmine era - emphasised cooperation between the states. The third, overseen by Karl von Varnbüler, ushered in the unification. However, this does little justice to the truly public nature of Württemberg's pan-Germanism. Throughout the nineteenth century, a large number of Swabian political figures, journalists, and diarists, all engaged with the idea of unity. As we should expect, not all of these diverse figures agreed on the correct approach to this. Their very involvement, though, shaped the public discourse, and to a great degree the direction of the crown's German policy. It is here, too, that we see the unprecedented dynamism of Württemberg's role in the German drive to unification, for the public engagement of ordinary Württembergers influenced not only their own government and the affairs of their own country, but also those of other states. It is no coincidence that many of the most influential representatives to the Frankfurt Parliament were from Württemberg, nor that Bismarck, long hailed as the architect of unification, held both Wilhelm and State Minister von Varnbüler in the highest esteem.

The Kingdom of Württemberg is not an analogue for the entire non-Prussian, nonAustrian German experience. The state faced similar problems and issues as other states of similar geographical and population size, but its circumstances were unique in many regards. Thus, what occurred in Württemberg between 1815 and 1871 should not be conflated with what occurred in Baden, or Bavaria, or Saxony, during the same time. What 
Württemberg's experience does demonstrate, though, is that the southern states (or, indeed, any of the German states beyond Prussia or Austria) may have played a far more active role in the unification of Germany than has previously been allowed. The lesson of this work goes well beyond the recognition of Württemberg's role; it is a timely reminder that our current historiographical model is flawed and exclusionary, and requires revision to free it from the Borussian school that defines Germany only in terms of Prussia. Time and again, Württemberg sought to shape Germany, and shape its position within whichever Germany would come into being. For the measure in which this development was welcomed by the Württemberg public, we should perhaps look no further than the parochial and staunchly particularist Schwäbischer Merkur newspaper - or, rather, to its editor-in-chief, Otto Elben. By November 1870, with war raging in France, the unification of the German states under Prussian leadership was all but inevitable. Far from despairing, however, Elben was ecstatic. "I am writing this to you as a happy German", he wrote to the prominent liberal, Eduard Lasker. "We are Germans, entering a federation of our brothers."

From all walks of Württemberg political and private life, this unification was a time for celebration, an endgame that was the natural conclusion of the circumstances that had come before it. In this endgame, Württemberg had not played the decisive move. But it had done much to manoeuvre all the pieces into the winning positions. The proclamation in Versailles was nothing more than a formality. Far from Germany being forged reluctantly, through impromptu negotiations as late as November and December 1870, the formation of the German Empire had been completed in all but formal regulations and statutes as

\footnotetext{
${ }^{1}$ Otto Elben to Eduard Lasker, 19 November 1870, in Otto Elben, Lebenserinnerungen, 1823-1899 (Stuttgart: W. Kohlhammer, 1931), 163-164.
} 
early as 1867 and 1868.2 The brief interruption of the Franco-Prussian War had been nothing but an impetus to come to an agreement as quickly as possible. The southern states provided troops far more willingly to the German war against France than they did to the Austrian war against Prussia precisely because this was perceived as a national war of defence. As always, while the groundwork for national unification had been laid by the political machinations of each state government, it was fear of the French - in this case, both a fear of their offensive desires and a fear that they might once more descend into rebellion that spurred Stuttgart, Munich, Karlsruhe and Berlin to put the finishing touches to their somewhat ad hoc national masterpiece.

The enthusiasm for this unification, after nearly six decades of ambivalence, spurned chances and nationalist disappointment, is best reflected in State Minister von Varnbüler himself. In the first days of September 1870, news filtered through to Stuttgart of the most dramatic event of the war. The combined German forces had won a major victory at Sedan. Napoleon III himself had been captured. This was a famous victory, not just for Prussia, but for all the German states. Normally a sober and measured man, Varnbüler seems to have been overcome with excitement at the news. Without notifying King Karl first, the state minister rushed to address the gathered crowds in the centre of Stuttgart, proclaiming the victory at Sedan as a national glory. ${ }^{3}$ His enthusiasm would earn him the ire of Karl, who dismissed him from office almost immediately, but this did little to harm Varnbüler's political career. Indeed, in the afterglow of unification, he became a respected and important member of the Reichstag, and at one stage was even considered for the office of

\footnotetext{
${ }^{2}$ Reflective of the orthodox view of German unification, Geoffrey Wawro notes that negotiations in Versailles between Württemberg, Bavaria, Baden and Prussia in late 1870 were intensive and often heated. However, given the fact that these states had already tied their fortunes to a "national" movement several years prior, these negotiations were not to determine the existence of Germany (which was, by now, a foregone conclusion), but rather the exact form that that Germany would take. Obviously, the amalgamation of these states into a national body did not restrict their governments' desire to reach a deal that would be beneficial to each state. Geoffrey Wawro, The Franco-Prussian War, 302.
}

${ }^{3}$ Abigail Green, Fatherlands, 298. 
chancellor of the German Empire. ${ }^{4}$ Perhaps this episode, more than any other, acts as the metaphor for the entire experience of Württemberg, for just as Varnbüler passionately embraced the national cause, losing his job but gaining greater glories, so too did Württemberg, grasping hungrily for national unification, lose its independent sovereignty but become part of the greater whole. In the final analysis, the proclamation of the German Empire in the Hall of Mirrors was not defeat for Württemberg, but victory.

\footnotetext{
${ }^{4}$ Irmline Veit-Brause, "Local and National Elites in the German Empire: The Case of the Württemberg Varnbülers", German Politics \&̊ Society 19, 3 (Fall 2001), 44-45.
} 



\title{
BIBLIOGRAPHY
}

\author{
I. ARCHIVAL LOCATIONS \\ BERLIN. \\ Bundesarchiv Berlin \\ Berlin-Lichterfelde \\ BArch.R101 - Reichsministerium des Innern \\ BArch.R101/2904/31776 \\ BArch.R1401 - Reichskanzleramt 1867-1879 \\ BArch.R1401/1524 \\ BArch.R1401/1567
}

\section{Geheimes Staatsarchiv Preußischer Kulturbesitz \\ Berlin-Dahlem}

GStAPK III. HA MdA - Ministerium der Auswärtigen Angelegenheiten

GStAPK III. HA MdA, I. Nr.4439 - Okkupation von

Hohenzollern im Namen des Deutschen Bundes durch

Württemberg (Jun. - Nov. 1866)

GStAPK III. HA MdA, I. Nr.4440 - Friedens- und Bündnisvertrag zwischen Preußen und Württemberg, Berlin, 13 August 1866 (Aug. 1866)

Politisches Archiv des Auswärtigen Amts

Berlin-Mitte

PAdAA Aktenserien Deutschland

PAdAA IAAb 88/R641 Nr.11584

PAdAA IAAb 92/R662 Nr.11667

PAdAA IAAb 92/R663 Nr.11673

DARMSTADT.

Hessisches Staatsarchiv Darmstadt

Darmstadt

Hes.StAD G1 - Behörden und Ämter Großherzogtum und Volkstaat Hessen Staatsministerium

Hes.StAD G1/147/7 - Ministerialakten über die Konferenzen zu

Wien, hier: württembergische Protest gegen eine Additional-Akte (1820) 
ESSLINGEN.

Stadtarchiv Esslingen

Esslingen am Neckar

StadtAE. I/2 Bü.3 (1819)

KARLSRUHE.

Generallandesarchiv Baden

Karlsruhe

GlaB 46/7153 - Haus- und Staatsarchiv: I. Personalia (1162-1925)

GlaB 48/2748 - Haus- und Staatsarchiv: III. Staatssachen (1542-1932)

GlaB 48/1463 - Haus- und Staatsarchiv: III. Staatssachen (1542-1932)

LONDON.

National Archives

Kew

FO 82 - Foreign Office: Political and Other Departments: General Correspondence before 1906: Baden and Württemberg

FO 82/25 - Edward Cromwell Disbrowe and Charles H. Hall, Domestic, Count Mandelsloh etc. (1831)

FO 82/26 - Sir Edward Cromwell Disbrowe (1832)

FO 82/36 - Sir George Shee and W. Wellesley, Domestic, Count Mandelsloh and various (1840)

FO 82/42 - Sir G. Shee, Mr. Wellesley, and Mr. Craven (1843)

FO 82/49 - Sir A. Malet (1846)

\section{STUTTGART.}

\section{Hauptstaatsarchiv Stuttgart}

Stuttgart

HStAS.A203 Bü.27 - Geheimer Rat: Landstände (1603-1805)

HStAS.E9 Bü.25 - Königliches Kabinett I: Ministerium der auswärtigen Angelegenheiten (1806-1872)

HStAS.E14 Bü.824 - Preußen: Politische und militärische Verhältnisse, Verfassungsangelegenheiten, württembergische und preußische Gesandtschaft, Verhandlungen, Übereinkünfte, Miszellen (1811-1833)

HStAS.E31/32 Bü.405 - Feudalabgaben im Herzogtum bzw. Königreich Württemberg [old signature] 
HStAS.E40/16 Bü.66 - Herstellung eines gemeinsames Indigenats und Regelung der Freizügigkeit mit dem Norddeutschen Bund (1868-1870)

HStAS.E40/18 Bü.409 - Neutralität Großbritanniens im deutschfranzösischen Krieg 1870 (1870-1871)

HStAS.E40/72 Bü.442 - Verfassung und Organisation des Norddeutschen Bundes, Verhältnis der süddeutschen Staaten, namentlich Württembergs zu Preußen bzw. zum Norddeutschen Bund (5 May - 12 Nov. 1867, 1869)

HStAS.E40/72 Bü.443 - Südbund-Projekt (1866-1870)

HStAS.E50/01 Bü.54 - Berichte des Gesandten von Sternenfels (May 1848 - March 1849)

HStAS.E50/01 Bü.765 - Militärische Maßnahmen in Reaktion auf die Revolution von 1848 (1848-1849)

HStAS.E50/01 Bü.875 - Politische Lage Europas: Krieg um die italienischen Staaten im Vorfeld der Nationalen Einigung (Jan. - Sep. 1859)

HStAS.E50/01 Bü.877 - Verteidigungsmaßnahmen hinsichtlich des Krieges in Italien und verschiedene dadurch bedingte innere Angelegenheiten (Jan. - Nov. 1860)

HStAS.E50/05 Bü.162 - Berichte des Gesandten in München, Ferdinand Christoph Graf von Degenfeld-Schomburg, und des Legationssekretärs Adolph Freiherr von Ow (30 Jan - 21 Dec. 1851)

HStAS.E50/12 Bü.143 - Berichte des Gesandten in Paris Karl August von Wächter sowie seines Stellvertreters Axel von Varnbüler (2 Jul. - 31 Dec. 1868)

HStAS.E50/12 Bü.147 - Berichte des Gesandten in Paris Karl August von Wächter (1 Apr. - 3 Jul. 1870)

HStAS.E65 Bü.106 - Teilnahme des Deutschen Bundes an der Pariser Verhandlungen Frankreichs, Großbritanniens und Russlands zur Aufrechterhaltung des Friedens 1866 (1866)

HStAS.E70a Bü.537 - Berichte des Grafen von Gallatin über Organisation und Stärke des französischen Heeres (1819)

HStAS.E70f Bü.164 - Deutsche Frage (1863-1870)

HStAS.E75 Bü.172 - Schriftwechsel mit dem Außenministerium in Stuttgart (1830) 
HStAS.E221 Bü.2626 - Administration von Weinzehnten [old signature]

HStAS.E271c Bü.803 - Telegramm zur dringenden Absendung einer Brigade nach Frankfurt (16 Jun. 1866)

HStAS.E271c Bü.805 - Dislokation der Truppen unter anderem im Raum Ludwigsburg, am 18. und 28. Juni sowie am 4. Juli 1866 (18 Jun. - 28 Sep. 1866)

HStAS.E271c Bü.848 - Aufruf an die 'Frauen und Jungfrauen' zur Fertigung von schwarzrot-goldenen Armbinden für das VIII. Bundesarmeekorps; Angebote von Firmen; Übersendung der Feldbinden (25 Jun. - 19 Jul. 1866)

HStAS.E271c Bü.915 - Petitionen verschiedener Volksvereine um Untersuchung der Kriegsführung des VIII. Deutschen Bundesarmeekorps, insbesondere der württembergischen Felddivision (6 - 31 Oct. 1866)

HStAS.E271c Bü.916 - Berichte einzelner Militärs zum Feldzug 1866 (18 Oct. 1866 - 6 Jun. 1867) HStAS.P10 Nr.849 - Zeitungsartikel, Protokolle und Auszüge von Reden Varnbülers, Zeitungsartikel über seine Politik (1845-1882)

HStAS.G313 Bü.12 - Krankheitsgeschichte und Tod König Karls (1884-1891, 1953)

HStAS.P10 Bü.722 - Wirken Karl Varnbülers als Mitglied des Engeren Ausschusses der Landwirtschaftlichen Vereine Deutschlands während des Kongresses in Frankfurt/Main am 30. April 1849 (1843, 1847-1849)

HStAS.P10 Bü.731 - Von Bismarck an Karl Varnbüler: Ablehnung von Varnbülers Vorschlag, dänische Überseeische Kolonien zu erwerben (16 August 1864)

HStAS.P10 Bü.847 - Unterredung Karl Varnbülers mit König Wilhelm I. Anfang Juni 1855; Niederschrift über das Familienleben, Vorstellungen und politische Meinung des Königs (25 Jun. 1855) 


\section{PRIMARY SOURCES}

Allgemeine Zeitung. 8 November 1831.

Allgemeine Zeitung. Nr.331. 27 November 1859. HStAS.E50/01 Bü.877.

Arndt, Ernst Moritz. Des Teutschen Vaterland. 1814.

Aufwartung am Neujahrs-Tage 1851. Munich. HStAS.E50/05 Nr.162.

Bacherer, Gustav. Süddeutsche Rufe aus Nord-Deutschland. Alle deutsche Ständeversammlungen und dem deutschen Volke. Nebst einer Antwort für den Fürsten Ludwig von Solms-Lich. Leipzig. Fest. 1839.

Badische Landeszeitung. 6 May 1866. HStAS.E70f Bü.164.

Bayerische Zeitung. Nr.103. 14 April 1866.

Bayerische Zeitung. Nr.155. 6 June 1866.

Beitrag zur Kenntniß der gegenseitigen Verbältnisse der Gewerbe und des Handels in Würtemberg und Preußen. Einer hohen Ständeversammlung gewidmet. Stuttgart. 1833.

Der Beobachter. No.39. 10 April 1848.

Der Beobachter. Nr.30-32. 6-9 February 1859.

Der Beobachter. Nr.76. 4 April 1866.

Der Beobachter. No.66. 20 March 1867. HStAS.E70f Bü.164.

Der Beobachter. Nr.25. 31 January 1868.

Der Beobachter. No.60. 12 March 1868. HStAS.E70f Bü.164.

Berckheim, Karl Christian von, to Grand Duke Leopold von Zähringen. Karlsruhe. 6 March 1831. GlaB 46/7153.

Beust, Count Ferdinand von, to Baron Karl Eugen von Hügel. Nr.57. Dresden. 19 July 1860. HStAS.E50/01 Bü.877.

Bismarck, Count Otto von, to Ludwig von Wildenbruch. Berlin. 25 September 1848. In Barrett-Lennard, C.E. Bismarck's Pen: The Life of Heinrich Abeken. London. George Allen \& Company. 1911.

to Baron Friedrich Karl Gottlob Varnbüler von und zu Hemmingen. Gastein. 16 August 1864. HStAS.P10 Bü.731. 
, to Johanna von Bismarck. Jitschin. 2 July 1866. In Bismarck, Count Otto von. Fürst Bismarcks Briefe an seine Braut und Gattin. Ed. Bismarck, Herbert von. Stuttgart. J.G. Cotta'sche Buchhandlung. 1900.

Blittersdorf, Baron Friedrich Landolin Karl von, to the Badenese Foreign Ministry. Frankfurt am Main. 2 April 1831. GlaB 48/1463.

Bloomfield, Lord John Arthur Douglas, to Lord John Russell. No.163. Vienna. 9 August 1865. In British Envoys to Germany, 1816-1866. Vol.IV: 1851-1866. Eds. Mösslang, Markus, Manias, Chris and Riotte, Torsten. Cambridge. Cambridge University Press. 2010.

, to George Villiers, Earl of Clarendon. No.411. Vienna. 5 July 1866. In British Envoys to Germany, 1816-1866. Vol.IV: 1851-1866. Eds. Mösslang, Markus, Manias, Chris and Riotte, Torsten. Cambridge. Cambridge University Press. 2010.

Blücher, Field Marshal Gebhard Leberecht von, Prince of Wahlstatt, to King Friedrich August von Wettin. Liège. 6 May 1815. In Treitschke, Heinrich von. History of Germany in the 19th Century. Vol.2: The Germanic Federation. London. G. Allen \& Unwin. 1916.

Blumenthal, Robert von, to Count Otto von Bismarck. Sigmaringen. 14 August 1866. GStAPK III. HA I, Nr.4439. , to Count Otto von Bismarck. Sigmaringen. 29 October 1866. GStAPK III. HA I, Nr.4439.

Die Bote aus Westen. 19 February 1832.

Böttigheimer, F., to Württemberg Ministry of War. Stuttgart. 30 June 1866. HStAS.E271c Bü.848.

Briefe von und an Klopstock: Ein Beitrag zur Literaturgeschichte seiner Zeit. Ed. Lappenberg, J.M. Braunschweig. 1867.

British Envoys to Germany, 1816-1866. Vol.I: 1816-1829. Eds. Freitag, Sabine and Wende, Peter. Cambridge. Cambridge University Press. 2000.

British Envoys to Germany, 1816-1866. Vol.II: 1830-1847. Eds. Mösslang, Markus, Freitag, Sabine and Wende, Peter. Cambridge. Cambridge University Press. 2002.

British Envoys to Germany, 1816-1866. Vol.III: 1848-1850. Eds. Mösslang, Markus, Riotte, Torsten and Schulze, Hagen. Cambridge. Cambridge University Press. 2006.

British Envoys to Germany, 1816-1866. Vol.IV: 1851-1866. Eds. Mösslang, Markus, Manias, Chris and Riotte, Torsten. Cambridge. Cambridge University Press. 2010. 
Casanova, Giacomo. The Memoirs of Jacques Casanova de Seingalt. Vol.III: The Eternal Quest. New York. G.P. Putnam’s Sons. 1961.

Castlereagh, Robert Stewart, to Charles W. Stewart. Foreign Office. London. 9 July 1816. In British Envoys to Germany, 1816-1866. Vol.I: 1816-1829. Eds. Freitag, Sabine and Wende, Peter. Cambridge. Cambridge University Press. 2000.

Clausewitz, Carl von. "Agitation." In Clausewitz, Carl von. Historical and Political Writings. Eds. Paret, Peter and Moran, Daniel. Princeton. Princeton University Press. 1992.

. Historical and Political Writings. Eds. Paret, Peter and Moran, Daniel. Princeton. Princeton University Press. 1992.

Constitutionelle Zeitung. Nr.165. 14 June 1859. HStAS.E50/01 Bü.877.

Conversation between King Wilhelm I. von Württemberg and Karl von Varnbüler. HStAS.P10 Nr.847.

Cotta, Johann Friedrich, to Johann Wolfgang von Goethe. 16 November 1808. In Neugebauer-Wölk, Monika. Revolution und Constitution. Die Brüder Cotta: Eine biographische Studie zum Zeitalter der Französischen Revolution und des Vormärz. Berlin. Siedler. 1989.

Derneburg, Georg Herbert Münster von. Der norddeutsche Bund und dessen Übergang zu einem deutschen Reiche. Leipzig. Brockhaus. 1868.

Deutsche Bundesakte. Frankfurt am Main. 8 July 1815.

Dietrich, Gustav and Sybel, Alexander von, to Count Otto von Bismarck. Berlin. 28 February 1868. BArch.R/1401/1524.

Disbrowe, Edward Cromwell, to Viscount Palmerston. No.13. Stuttgart. 24 March 1831. FO $82 / 25$. 1832. FO $82 / 26$.

, to Henry John Temple, Viscount Palmerston. No.1. Stuttgart. 8 January to Henry John Temple, Viscount Palmerston. No.8. Stuttgart. 15 February 1832. FO 82/26.

, to Henry John Temple, Viscount Palmerston. No.49. Stuttgart. 30 September 1832. In British Envoys to Germany, 1816-1866. Vol.II: 1830-1847. Eds. Mösslang, Markus, Freitag, Sabine and Wende, Peter. Cambridge. Cambridge University Press. 2002. 
Dokumente der Deutschen Politik und Geschichte von 1848 bis zur Gegenwart: Ein Quellenwerk für die politische Bildung und staatsbürgerliche Erziehung. Ed. Hohlfeld, Johannes. 1.Bd. Amsterdam. Swets \& Zeitlinger. 1973.

Dönhoff, August Heinrich Hermann von, to Count Otto von Bismarck. No.41. Stuttgart. 10 June 1868. PAdAA IAAb 92/R663 Nr.11673.

Eckermann, Johann Peter. Gespräche mit Goethe in den letzten Jahren seines Lebens. 3.Bd. Leipzig. F.A. Brockhaus. 1885.

Eckert, Heinrich A. Das deutsche Bundesheer. Munich. 1835.

Eggert, C.A. "The True Causes of the French-Prussian War." Putnam's Monthly Magazine of American Literature, Science and Art. 16, 34 (October 1870): 450-457.

Elben, Otto, to Eduard Lasker. 19 November 1870. In Elben, Otto. Lebenserinnerungen, 1823-1899. Stuttgart. W. Kohlhammer. 1931.

- Geschichte des Schwäbischen Merkurs, 1785-1885. Stuttgart. Schwäbischer Merkur. 1885.

. Lebenserinnerungen, 1823-1899. Stuttgart. W. Kohlhammer. 1931.

Fetzer, Dr. Berthold von. "Geschichte der Krankheit der verewigten Königs Karl Majestät." 18 October 1884. HStAS.G313 B.12.

La France. 14 July 1868. HStAS.E50/12 Bü.143.

La France. 30 April 1870. HStAS.E50/12 Bü.147.

Freytag, Gustav. Karl Mathy: Geschichte seines Lebens. Leipzig. S. Hirzel. 1870.

Friedens- und Bündnisvertrag zwischen Preußen und Württemberg. Berlin. 13 August 1866. GStAPK III. HA MdA, I. Nr.4440.

Friedrich, Albert, to Grand Duke Leopold von Zähringen. Stuttgart. 15 February 1831. GlaB 48/2748.

Friedrich Lists gesammelte Schriften. Ed. Häusser, Ludwig. 1.Bd. Stuttgart and Tübingen. J.G. Cotta'sche Verlag. 1850.

Frisch, Carl. "Vortrag von Oberfinanzrat Fritz im Oberfinanzkollegium über die Selbstadministration von Weinzehnten und Weingefällen bei der Kameralverwaltung." Stuttgart. 15 May 1820. HStAS.E221 Nr.2626.

Fröbel, Julius. “Circular.” 1 October 1867. HStAS.E40/72 Bü.442. 
Fürst Bismarcks Briefe an seine Braut und Gattin. Ed. Bismarck, Herbert von. Stuttgart. J.G. Cotta'sche Buchhandlung. 1900.

Gagern, Baron Heinrich von. Deutscher Liberalismus im Vormärz: Briefe und Reden, 1815-1848. Eds. Wentzcke, Paul and Klötzer, Wolfgang. Göttingen. Musterschmidt. 1959.

Garnison Ludwigsburg, Dislokation der Truppen am 18. Juni 1866. HStAS.E271c Bü.805.

Garnison Ludwigsburg, Dislokation der Truppen am 28. Juni 1866. HStAS.E271c Bü.805.

La Gazette de France. 31 December 1868. HStAS.E50/12 Bü.143.

Gesandtschaftsberichte aus München. Abt.II: Die Berichte der österreichischen Gesandten. Ed. Chroust, Anton. 2.Bd. Darmstadt. 2001.

Geschäftsbericht des engern Ausschusses des Congresses der Abgeordneten landwirthschaftlicher Vereine Deutschlands. Frankfurt am Main. 30 April 1849. HStAS.P10 Bü.722.

Goethe, Johann Wolfgang von, and Schiller, Friedrich. Goethe-Schillers Xenien. Aus dem Schillerschen "Musen-Almanach für das Jahr 1797" und dem "Xenien-Manuscript." Ed. Stern, Adolf. Leipzig. Philipp Reclam. 1871.

Goltz, Robert von der, to Count Otto von Bismarck. Paris. 5 July 1866. In Die Rheinpolitik Kaiser Napoleons III. von 1863 bis 1870 und der Ursprung des Krieges von 1870/71. Ed. Oncken, Hermann. 1.Bd.: 1863 bis Juli 1866. Stuttgart. Deutsche VerlagsAnstalt. 1926.

, to Count Otto von Bismarck. Paris. 14 July 1866. In Die Rheinpolitik Kaiser Napoleons III. von 1863 bis 1870 und der Ursprung des Krieges von 1870/71. Ed. Oncken, Hermann. 1.Bd.: 1863 bis Juli 1866. Stuttgart. Deutsche VerlagsAnstalt. 1926.

Gordon, George John Robert, to Lord John Russell. No.65. Stuttgart. 28 May 1861. In British Envoys to Germany, 1816-1866. Vol.IV: 1851-1866. Eds. Mösslang, Markus, Manias, Chris and Riotte, Torsten. Cambridge. Cambridge University Press. 2010.

, to Lord John Russell. No.17. Stuttgart. 11 February 1862. In British Envoys to Germany, 1816-1866. Vol.IV: 1851-1866. Eds. Mösslang, Markus, Manias, Chris and Riotte, Torsten. Cambridge. Cambridge University Press. 2010.

, to Lord John Russell. No.21. Karlsruhe. 16 February 1862. In British Envoys to Germany, 1816-1866. Vol.IV: 1851-1866. Eds. Mösslang, Markus, Manias, Chris and Riotte, Torsten. Cambridge. Cambridge University Press. 2010. 
, to George Villiers, Earl of Clarendon. No.21. Stuttgart. 28 March 1866. In British Envoys to Germany, 1816-1866. Vol.IV: 1851-1866. Eds. Mösslang, Markus, Manias, Chris and Riotte, Torsten. Cambridge. Cambridge University Press. 2010.

, to Lord Edward Henry Stanley. No.8. Stuttgart. 18 July 1866. In British Envoys to Germany, 1816-1866. Vol.IV: 1851-1866. Eds. Mösslang, Markus, Manias, Chris and Riotte, Torsten. Cambridge. Cambridge University Press. 2010.

Grimm, Jacob and Grimm, Wilhelm. Kinder- und Hausmärchen. 3.Bd. Göttingen. Dieterische Buchhandlung. 1843.

Großherzoglich Mecklenburg-Strelischer Offizieller Anzeiger für Gesetzgebung und Staatsverwaltung. No.10. 28 June 1867. PAdAA IAAb 88/R641 Nr.11584.

Habsburg, Kaiser Franz Joseph von, to King Wilhelm I. von Hohenzollern. Vienna. 6 August 1863. In Dokumente der Deutschen Politik und Geschichte von 1848 bis zur Gegenwart: Ein Quellenwerk für die politische Bildung und staatsbürgerliche Erziehung. Ed. Hohlfeld, Johannes. 1.Bd. Amsterdam. Swets \& Zeitlinger. 1973.

Hahn, Ludwig. Der Krieg Deutschlands gegen Frankreich und die Gründung des Deutschen Kaiserreichs. Die Deutsche Politik 1867 bis 1871. Berlin. Verlag Wilhelm Herz. 1871.

Hallische Jabrbücher für deutsche Wissenschaft und Kunst. No.138. 10 June 1839.

Hamilton, Hamilton, to Robert Stewart, Viscount Castlereagh. No.5. Stuttgart. 27 April 1822. In British Envoys to Germany, 1816-1866. Vol.I: 1816-1829. Eds. Freitag, Sabine and Wende, Peter. Cambridge. Cambridge University Press. 2000.

Hartmann, August von, to Holz. Stuttgart. 13 August 1830. HStAS.E75 Nr.172.

Hohenloe-Ingelfingen, Prince Kraft Karl August Eduard Friedrich zu. Auszeichnungen aus meinen Leben. 1.Bd. Berlin. 1897.

Hohenlohe, Prince Chlodwig von. Address to Abgeordnetenkammer. 8 October 1867. In Hahn, Ludwig. Der Krieg Deutschlands gegen Frankreich und die Gründung des Deutschen Kaiserreichs. Die Deutsche Politik 1867 bis 1871. Berlin. Verlag Wilhelm Herz. 1871.

Hohenzollern, King Friedrich II. von. "Idées sur les projets politiques à former au sujet de la mort de l'empereur." In Hohenzollern, King Friedrich II. von. Politische Correspondenzen Friedrichs des Großen. Eds. Droysen, Johann Gustav, Duncker, Max W., and Sybel, Heinrich von. 1.Bd. Berlin. A. Duncker. 1879.

. Politische Correspondenzen Friedrichs des Großen. Eds. Droysen, Johann Gustav, Duncker, Max W., and Sybel, Heinrich von. 1.Bd. Berlin. A. Duncker. 1879. 
Hohenzollern, King Wilhelm I. von, to Kaiser Franz Joseph von Habsburg. Gastein. 7 August 1863. In Dokumente der Deutschen Politik und Geschichte von 1848 bis zur Gegenwart: Ein Quellenwerk für die politische Bildung und staatsbürgerliche Erziehung. Ed. Hohlfeld, Johannes. 1.Bd. Amsterdam. Swets \& Zeitlinger. 1973.

Hölderlin, Friedrich. "An die Freiheit.” In Hölderlin, Friedrich. Sämtliche Gedichte. Ed. Detlev Lüders. 1.Bd. Bad Homburg. Athenäum Verlag. 1970.

Verlag. 1970.

. Sämtliche Gedichte. Ed. Detlev Lüders. 1.Bd. Bad Homburg. Athenäum

Hörnigk, Philip Wilhelm von. Oesterreich über Alles, wenn es nur will. Nürnberg. 1684.

Howard, Henry Francis, to Lord Edward Henry Stanley. No.65. Munich. 21 August 1866. In British Envoys to Germany, 1816-1866. Vol.IV: 1851-1866. Eds. Mösslang, Markus, Manias, Chris and Riotte, Torsten. Cambridge. Cambridge University Press. 2010.

Isny Council to Württemberg Ministry of War. Isny. 4 July 1866. HStAS.E271c Bü.848.

Kallee, Eduard von. "Ueber den Anteil des württembergischen Truppenkorps, der 1ten.

Division des 8ten. Bundesarmeekorps, von dem Kriege gegen Preußen, besonders die Führung betreffend." HStAS.E271c Bü.916.

Karlsruber Anzeiger. No.43. 20 February 1863. HStAS.P10 Bü.849.

Karlsruher Zeitung. 1 January 1866. HStAS.E70f Bü.164.

Karlsruher Zeitung. 3 April 1866. HStAS.E70f Bü.164.

Karlsruber Zeitung, 7 May 1866. HStAS.E70f Bü.164.

Karlsruber Zeitung. 15 October 1867. PAdAA IAAb 92/R662 Nr.11667.

Karlsruher Zeitung. 15 January 1869. BArch.R1401/1567.

Karlsruher Zeitung. No.20.21 January 1871. HStAS.E40/18 Bü.409.

Kleist, Heinrich von. "Katechismus der Deutschen." In Werke und Briefe in vier Bänden. Ed. Siegfried Seller. 3.Bd. Berlin. Aufbau. 1978. Aufbau. 1978.

. Werke und Briefe in vier Bänden. Ed. Siegfried Seller. 3.Bd. Berlin.

Klopstock, Friedrich Gottlieb. “Sie, und nicht wir." In Klopstock, Friedrich Gottlieb. Oden. 2.Bd. Leipzig. 1798.

. Oden. 2.Bd. Leipzig. 1798. 
to Johann Gottfried von Herder. 20 July 1799. In Briefe von und an Klopstock: Ein Beitrag zur Literaturgeschichte seiner Zeit. Ed. Lappenberg, J.M. Braunschweig. 1867.

Kombst, Heinrich Christian Gustaf von. Der deutsche Bundestag gegen Ende des Jahres 1832. Eine politische Skizze. Strasbourg. G.L. Schuler. 1836.

Königlich Württembergische Staats- und Regierungsblatt. 1817.

Kurpfalzbaierische Staats-Zeitung von München. No.CCLIX. 2 November 1805.

Das liberale Deutschland. 3 August 1831.

Leveson-Gower, Granville, Earl Granville, to Count Albrecht von Bernsdorff. London. 21 October 1870. HStAS.E40/18 Bü.409.

Linden, Baron Joseph Franz Peter von. Address to Bundestag. 1 June 1866. HStAS.E65 Bü. 106.

to Baron Friedrich Karl Gottlob Varnbüler von und zu Hemmingen. Augsburg. 11 August 1866. HStAS.E40/72 Bü.443.

Lindner, Friedrich Ludwig. Manuskript aus Süd-Deutschland. London. James Griphi. 1821.

Ueber die gegenwärtige Lage von Europa. Frankfurt a.M. and Leipzig. Friedrich Ludwig Lindner. 1821.

List, Friedrich. Die politisch-ökonomische Nationaleinheit der Deutschen. Aufsätze aus dem Zollvereinsblatt und andere Schriften der Spätzeit. Eds. Lenz, Friedrich and Wiskemann, Erwin. Berlin. R. Hobbing. 1931.

. "Reutlinger Petition" (1821). In Friedrich Lists gesammelte Schriften. Ed. Häusser, Ludwig. 1.Bd. Stuttgart and Tübingen. J.G. Cotta’sche Verlag. 1850.

. The National System of Political Economy. Ed. Lloyd, Sampson S. London. Longmans, Green and Co. 1909.

Loftus, Lord Augustus, to Henry John Temple, Viscount Palmerston. No.6. Stuttgart. 5 May 1847. In British Envoys to Germany, 1816-1866. Vol.II: 1830-1847. Eds. Mösslang, Markus, Freitag, Sabine and Wende, Peter. Cambridge. Cambridge University Press. 2002.

Magenis, Arthur Charles, to Henry John Temple, Viscount Palmerston. No.19. Vienna. 15 June 1848. In British Envoys to Germany, 1816-1866. Vol.III: 1848-1850. Eds. Mösslang, Markus, Riotte, Torsten and Schulze, Hagen. Cambridge. Cambridge University Press. 2006. 
Malet, Sir Alexander, to Henry John Temple, Viscount Palmerston. Stuttgart. 16 October 1846. FO 82/49.

, to Henry John Temple, Viscount Palmerston. No.16. Stuttgart. 10 March 1848. In British Envoys to Germany, 1816-1866. Vol.III: 1848-1850. Eds. Mösslang, Markus, Riotte, Torsten and Schulze, Hagen. Cambridge. Cambridge University Press. 2006.

, to George Villiers, Earl of Clarendon. No.60. Frankfurt. 5 May 1866. In British Envoys to Germany, 1816-1866. Vol.IV: 1851-1866. Eds. Mösslang, Markus, Manias, Chris and Riotte, Torsten. Cambridge. Cambridge University Press. 2010.

, to Baron Alois Kübeck von Kübau, President High Diet. Frankfurt am Main. 27 May 1866. HStAS.E65 Bü.106.

, to Baron Alois Kübeck von Kübau, President High Diet. Frankfurt am Main. 14 June 1866. HStAS.E65 Bü.106.

Manchester Guardian. 30 June 1866.

La Marseillaise, No.133. 2 May 1870. HStAS.E50/12 Bü.147.

Massenbach, Eveline von. Das Tagebuch der Baronin Eveline von Massenbach, Hofdame der Königin Olga von Württemberg. Stuttgart. Kohlhammer. 1987.

Le Mémorial Diplomatique. No.29. 16 July 1868. HStAS.E50/12 Bü.143.

Mensdorff-Pouilly, Count Alexander von, to Prince Richard von Metternich. Vienna. 2 July 1866 (2.30pm). In Die Rheinpolitik Kaiser Napoleons III. von 1863 bis 1870 und der Ursprung des Krieges von 1870/71. Ed. Oncken, Hermann. 1.Bd.: 1863 bis Juli 1866. Stuttgart. Deutsche Verlags-Anstalt. 1926.

, to Prince Richard von Metternich. Vienna. 2 July 1866 (9.50pm). In Die Rheinpolitik Kaiser Napoleons III. von 1863 bis 1870 und der Ursprung des Krieges von 1870/71. Ed. Oncken, Hermann. 1.Bd.: 1863 bis Juli 1866. Stuttgart. Deutsche Verlags-Anstalt. 1926.

Menzel, Wolfgang. Der Deutsche Krieg im Jahr 1866, in seinen Ursachen, seinem Verlauf und seinen nächsten Folgen. 2.Bd. Stuttgart. Adolph Krabbe. 1867.

Metternich, Prince Clemens Lothar Wenzel von, to Joseph von Trauttmansdorff. 18 March 1828. In Baack, Lawrence J. Christian Bernstorff and Prussia: Diplomacy and Reform Conservatism, 1818-1832. New Brunswick. Rutgers University Press. 1980.

, to Count Kaspar Philipp von Spiegel zum Desenberg. 21 April 1831. In Gesandtschaftsberichte aus München. Abt.II: Die Berichte der österreichischen Gesandten. Ed. Chroust, Anton. 2.Bd. Darmstadt. 2001. 
Milbanke, Sir John Ralph, to Lord John Russell. No.63. Munich. 28 May 1861. In British Envoys to Germany, 1816-1866. Vol.IV: 1851-1866. Eds. Mösslang, Markus, Manias, Chris and Riotte, Torsten. Cambridge. Cambridge University Press. 2010.

Militär-Wochenblatt. 8 July 1865.

Mohl, Robert von. "Die Geschichte der württembergischen Verfassung von 1819." Zeitschrift für die gesamte Staatswissenschaft. 6, 1 (1850): 44-121.

Moltke, Helmuth von. "De l'influence des armes perfectionées sur le combat." MilitärWochenblatt. 8 July 1865.

Le Moniteur. 3 May 1859. HStAS.E50/01 Bü.875.

Le Moniteur Universel. No.5a. 21 February 1819. HStAS.E70a Bü.537.

Le Moniteur Universel. 8 July 1868. HStAS.E50/12 Bü.143.

Moser, Friedrich Karl von. Von dem deutschen Nationalgeist. Selb. Notos. 1976.

Mülberger, Arthur. Die Eisenbahnreform in Württemberg. Tübingen. Laupp'schen Buchhandlung. 1896.

Neue Münchner Zeitung. Nr.2. 3 January 1849.

Neues Tagblatt für Stuttgart und Umgegend. No.156. 10 July 1845. HStAS.P10 Bü.849.

Norddeutsche Allgemeine Zeitung. 17 October 1867. HStAS.E40/72 Bü.442.

“Notes on the War, No.1." Manchester Guardian. 30 June 1866.

Oberrheinische Zeitung. No.98. 7 April 1848. HStAS.E50/01 Bü.765.

Österreichische Militärische Zeitschrift. 3 (1865).

Ow, Baron Adolf von, to Baron Karl Eugen von Hügel. Vienna. 12 July 1859. HStAS.E50/01 Bü.875. , to Baron Friedrich Karl Gottlob Varnbüler von und zu Hemmingen. Vienna. 22 May 1867. HStAS.E40/72 Bü.442.

Pahl, Johann Gottfried. Denkwürdigkeiten zur Geschichte von Schwaben während der beyden Feldzüge von 1799 und 1800. Nördlingen. Karl Gottlob Beck.1802.

Perglas, Baron Max Pergler, to Prince Chlodwig von Hohenlohe. Paris. 10 May 1867. In Die Rheinpolitik Kaiser Napoleons III. von 1863 bis 1870 und der Ursprung des Krieges von 1870/71. Ed. Oncken, Hermann. 2.Bd.: Juli 1866 bis Juli 1868. Stuttgart. Deutsche Verlags-Anstalt. 1926. 
Perthes, Jacques Boucher de. Voyage en Danemarck, en Suede, en Norvege, par la Belgique et la Hollande, retour par les villes anséatiques, le Mecklembourg, la Saxe, la Bavière, le Wurtemberg et le Grand-Duché de Bade, séjour à Bade en 1854. Paris. 1858.

Le Peuple Français. 2 May 1870. HStAS.E50/12 Bü.147.

Pfaff, Karl. Geschichte des Militärwesens in Württemberg. Stuttgart. Schweizenbart. 1842.

Pfälzer Zeitung. Nr.233. 6 October 1862.

Pfister, Albert. Aus dem Lager der Verbündeten 1814 und 1815. Stuttgart. Deutsche Verlags-Anstalt. 1897. J.G. Cotta. 1902.

. Deutsche Zwietracht, Erinnerungen aus meiner Leutnantszeit. Stuttgart.

Pfordten, Baron Karl Ludwig von der, to Maximilian II von Wittelsbach. 2 March 1852. In Hanisch, Manfred. Für Fürst und Vaterland. Legitimätsstiftung in Bayern zwischen Revolution 1848 und deutscher Einheit. Munich. Oldenbourg. 1991.

, to King Ludwig II von Wittelsbach. Berlin. 13 August 1866. In Die Rheinpolitik Kaiser Napoleons III. von 1863 bis 1870 und der Ursprung des Krieges von 1870/71. Ed. Oncken, Hermann. 2.Bd.: Juli 1866 bis Juli 1868. Stuttgart. Deutsche Verlags-Anstalt. 1926.

Pönitz, Karl Eduard. Die Eisenbahnen und ibre Benutzung aus militärische Operazionslinien. Adorf. Verlags-Bureau. 1853.

- Die Vertheidigung von Süddeutschland gegen die Franzosen, mit Zuziehung der Eisenbahnen, unter Berücksichtigung der verschiedenen Spurweiten. Tübingen. J.G. Cotta. 1844.

Ponsonby, John, to Henry John Temple, Viscount Palmerston. No.378. Vienna. 18 October 1848. In British Envoys to Germany, 1816-1866. Vol.III: 1848-1850. Eds. Mösslang, Markus, Riotte, Torsten and Schulze, Hagen. Cambridge. Cambridge University Press. 2006.

La Presse. 1 May 1870. HStAS.E50/12 Bü.147.

Preussische Statistik. 8.Bd. Berlin. Preussisches Königliches Statistisches Landesamt. 1865.

Quellen zur deutschen Politik Österreichs 1859-1866. Ed. Srbik, Heinrich Ritter von. 4.Bd.: März 1864 bis August 1865. Oldenburg. Stalling. 1937.

Receipt from Neues Tagblatt to Württemberg Ministry of War. 12 July 1866 . HStAS.E271c Bü.848. 
Report of 4.2.1865. Stuttgart. 4 February 1865. In Quellen zur deutschen Politik Österreichs 1859-1866. Ed. Srbik, Heinrich Ritter von. 4.Bd.: März 1864 bis August 1865. Oldenburg. Stalling. 1937.

Report of the United Representatives for Customs and Taxes and for Trade and Transport. Bundesrath Session No.12. BArch.R1401/1567.

Rhein-Lahn-Zeitung. No.94. 22 June 1859.

Die Rheinpolitik Kaiser Napoleons III. von 1863 bis 1870 und der Ursprung des Krieges von 1870/71. Ed. Oncken, Hermann. 1.Bd.: 1863 bis Juli 1866. Stuttgart. Deutsche Verlags-Anstalt. 1926.

Die Rheinpolitik Kaiser Napoleons III. von 1863 bis 1870 und der Ursprung des Krieges von 1870/71. Ed. Oncken, Hermann. 2.Bd.: Juli 1866 bis Juli 1868. Stuttgart. Deutsche Verlags-Anstalt. 1926.

Riecke, Karl Viktor von. "Zur Vorgeschichte des Deutschen Zollvereins. Auszüge aus Briefen des Freiherrn K.A. v. Wangenheim.” Württembergische Vierteljahrshefte für Landesgeschichte. 2 (1879): 101-111.

Rose, Sir George H., to Robert Stewart, Viscount Castlereagh. No.33. Berlin. 10 April 1819. In British Envoys to Germany, 1816-1866. Vol.I: 1816-1829. Eds. Freitag, Sabine and Wende, Peter. Cambridge. Cambridge University Press. 2000.

, to Robert Stewart, Viscount Castlereagh. No.35. Berlin. 13 April 1819. In British Envoys to Germany, 1816-1866. Vol.I: 1816-1829. Eds. Freitag, Sabine and Wende, Peter. Cambridge. Cambridge University Press. 2000.

, to Robert Stewart, Viscount Castlereagh. No.40. Berlin. 22 April 1819. In British Envoys to Germany, 1816-1866. Vol.I: 1816-1829. Eds. Freitag, Sabine and Wende, Peter. Cambridge. Cambridge University Press. 2000.

, to Robert Stewart, Viscount Castlereagh. No.42. Berlin. 29 April 1819. In British Envoys to Germany, 1816-1866. Vol.I: 1816-1829. Eds. Freitag, Sabine and Wende, Peter. Cambridge. Cambridge University Press. 2000.

, to Robert Stewart, Viscount Castlereagh. No.75. Berlin. 10 July 1819. In British Envoys to Germany, 1816-1866. Vol.I: 1816-1829. Eds. Freitag, Sabine and Wende, Peter. Cambridge. Cambridge University Press. 2000.

, to Robert Stewart, Viscount Castlereagh. No.76. Berlin. 13 July 1819. In British Envoys to Germany, 1816-1866. Vol.I: 1816-1829. Eds. Freitag, Sabine and Wende, Peter. Cambridge. Cambridge University Press. 2000.

, to Robert Stewart, Viscount Castlereagh. No.78. Berlin. 15 July 1819. In British Envoys to Germany, 1816-1866. Vol.I: 1816-1829. Eds. Freitag, Sabine and Wende, Peter. Cambridge. Cambridge University Press. 2000. 
, to Robert Stewart, Viscount Castlereagh. No.79. Berlin. 20 July 1819. In British Envoys to Germany, 1816-1866. Vol.I: 1816-1829. Eds. Freitag, Sabine and Wende, Peter. Cambridge. Cambridge University Press. 2000.

, to Robert Stewart, Viscount Castlereagh. No.81. Berlin. 24 July 1819. In British Envoys to Germany, 1816-1866. Vol.I: 1816-1829. Eds. Freitag, Sabine and Wende, Peter. Cambridge. Cambridge University Press. 2000.

, to Robert Stewart, Viscount Castlereagh. No.83. Berlin. 3 August 1819. In British Envoys to Germany, 1816-1866. Vol.I: 1816-1829. Eds. Freitag, Sabine and Wende, Peter. Cambridge. Cambridge University Press. 2000.

, to Robert Stewart, Viscount Castlereagh. No.100. Berlin. 30 September 1819. In British Envoys to Germany, 1816-1866. Vol.I: 1816-1829. Eds. Freitag, Sabine and Wende, Peter. Cambridge. Cambridge University Press. 2000.

Rüpplin, Baron August von, to Karl Ludwig Friedrich Roser. Stuttgart. 24 July 1848. HStAS.E50/01 Bü.765.

"Die Schiessübungen der k. preussischen Infanterie." Österreichische Militärische Zeitschrift. 3 (1865).

Schiller, Friedrich. Die Räuber. Ein Schauspiel von fünf Akten. Frankfurt am Main. 1787. to Christian Gottfried Körner. Rudolstadt. 15 April 1790. In Schiller, Friedrich von. Schillers Briefwechsel mit Körner von 1784 bis zum Tode Schillers. 1.Bd. Leipzig. Verlag von Veit \& Comp. 1859.

. "Das deutsche Reich" (1797). In Goethe, Johann Wolfgang von, and Schiller, Friedrich. Goethe-Schillers Xenien. Aus dem Schillerschen "Musen-Almanach für das Jahr 1797" und dem "Xenien-Manuscript." Ed. Stern, Adolf. Leipzig. Philipp Reclam. 1871.

. Schillers Briefwechsel mit Körner von 1784 bis zum Tode Schillers. 1.Bd. Leipzig. Verlag von Veit \& Comp. 1859.

Schmoller, Gustav. "Die Resultate der pro 3. Dezember 1861 aufgenommenen Gewerbestatistik." In Württembergische Jahrbücher für vaterländische Geschichte, Geographie, Statistik und Topographie. Stuttgart.Verlag von Karl Aue. 1862.

Schön, Julius. Das gezogene Infanterie-Gewehr: Kurze Darstellung der Waffensysteme der Neuzeit und ihrer Anwendung in den Armeen Europas. Dresden. C. Höckner. 1854.

Schroeder, Paul W. "The Lost Intermediaries: The Impact of 1870 on the European System.” The International History Review. 6, 1 (February 1984): 1-27.

Schubert, Friedrich Wilhelm. Handbuch der allgemeinen Staatskunden von Europa. 1.Bd. 3.Teil: Die Reiche Spanien und Portugal. Königsberg. Gebrüder Bornträger. 1836. 
Schulz, Wilhelm Friedrich. Deutschlands Einheit durch Nationalrepräsentation. Stuttgart. Schweizerbart. 1832.

Schutz- und Trutzbündnisvertrag zwischen Preußen und Bayern. 22 August 1866. In Hahn, Ludwig. Der Krieg Deutschlands gegen Frankreich und die Gründung des Deutschen Kaiserreichs. Die Deutsche Politik 1867 bis 1871. Berlin. Verlag Wilhelm Herz. 1871.

Schwäbische Kronik. 3 October 1841.

Schwäbische Kronik. No.62. 3 March 1848.

Schwäbische Kronik. No.62-78. 3-19 March 1848.

Schwäbische Kronik. No.109. 19 April 1848.

Schwäbischer Merkur. 1 April 1866.

Shee, George, to Viscount Palmerston. No.29. Stuttgart. 9 October 1840. FO 82/36.

Soden, Baron Oskar von, to Baron Friedrich Karl Gottlob Varnbüler von und zu Hemmingen. Karlsruhe. 7 May 1866. HStAS.E70f Bü.164.

Speckle, Ignaz. Das Tagebuch von Ignaz Speckle, Abt von St. Peter im Schwarzwald. 2.Bd. Stuttgart. Kohlhammer. 1966.

Spitzemberg, Hildegard von. Das Tagebuch der Baronin Spitzemberg 1859-1914. Göttingen. Vandenhoeck \& Ruprecht. 1961.

Spitzemberg, Baron Karl Hugo von, to Baron Friedrich Karl Gottlob Varnbüler von und zu Hemmingen. Berlin. 13 May 1867. HStAS.E40/72 Bü.442.

to Baron Friedrich Karl Gottlob Varnbüler von und zu Hemmingen. Berlin. 18 May 1867. HStAS.E40/72 Bü.442.

Staats-Anzeiger für Württemberg. No.40-41. 15-16 February 1850.

Staats-Anzeiger für Württemberg. No.167. 14 July 1850.

Staats-Anzeiger für Württemberg. 18 August 1850.

Staats-Anzeiger für Württemberg. No.296. 14 December 1861.

Staats-Anzeiger für Württemberg. 24 January 1864.

Stein, Baron Heinrich Friedrich Karl vom und zum, to Count Ernst Friedrich Herbert zu Münster. 1 December 1812. In Seeley, John R. Life and Times of Stein, or, Germany and Prussia in the Napoleonic Age. Vol.3. Cambridge. University Press. 1878. 
Sternenfels, Karl von. "Die württembergischen Abgeordneten in den Fraktionen der Nationalversammlung (Oktober 1848).” Frankfurt am Main. 1 November 1848. HStAS.E50/01 Bü.54.

Stewart, Charles W. to Robert Stewart, Viscount Castlereagh. No.51. Vienna. 23 June 1816. In British Envoys to Germany, 1816-1866. Vol.I: 1816-1829. Eds. Freitag, Sabine and Wende, Peter. Cambridge. Cambridge University Press. 2000.

, to Robert Stewart, Viscount Castlereagh. No.1. Vienna. 1 October 1819. In British Envoys to Germany, 1816-1866. Vol.I: 1816-1829. Eds. Freitag, Sabine and Wende, Peter. Cambridge. Cambridge University Press. 2000.

Sturm, Johann Heinrich, to Duke Friedrich Karl von Württemberg. Stuttgart. 3 June 1692. HStAS.A203 Nr.27.

Taube, Countess von, to Württemberg Ministry of War. Stuttgart. 5 July 1866. HStAS.E271c Bü.848.

Taylor, Sir Brook, to Robert Stewart, Viscount Castlereagh. No.24. Stuttgart. 25 October 1819. In British Envoys to Germany, 1816-1866. Vol.I: 1816-1829. Eds. Freitag, Sabine and Wende, Peter. Cambridge. Cambridge University Press. 2000.

, to Robert Stewart, Viscount Castlereagh. No.27. Stuttgart. 21 November 1819. In British Envoys to Germany, 1816-1866. Vol.I: 1816-1829. Eds. Freitag, Sabine and Wende, Peter. Cambridge. Cambridge University Press. 2000.

, to Robert Stewart, Viscount Castlereagh. No.42. Stuttgart. 22 November 1817. In British Envoys to Germany, 1816-1866. Vol.I: 1816-1829. Eds. Freitag, Sabine and Wende, Peter. Cambridge. Cambridge University Press. 2000.

Thil, Baron Karl Wilhelm Heinrich du Bos du, to Foreign Ministry (Hesse-Darmstadt). No.99. Vienna. 27 March 1820, HStAD.G1/147/7.

Thumb von Neuburg to Baron Friedrich Karl Gottlob Varnbüler von und zu Hemmingen. Vienna. 20 December 1867. HStAS.E40/72 Bü.442.

Trollope, Frances. Vienna and the Austrians; with Some Account of a Journey through Swabia, Bavaria, the Tyrol and Salzbourg. London. R. Bentley. 1838.

“Ueber die teutschen Gesellschaften.” Allemannia. 1, 1 (January 1815): 277.

Varnbüler von und zu Hemmingen, Baron Friedrich Karl Gottlob. Ueber die Frage eines deutschen Heimathrechtes. Stuttgart. Verlag von Aug. Schaber. 1864. HStAS.E40/16 Bü.66. 
to Baron Karl August von Wächter. Stuttgart. 10 June 1866. In Die Rheinpolitik Kaiser Napoleons III. von 1863 bis 1870 und der Ursprung des Krieges von 1870/71. Ed. Oncken, Hermann. 1.Bd.: 1863 bis Juli 1866. Stuttgart. Deutsche Verlags-Anstalt. 1926.

, to Prince Chlodwig von Hohenlohe. Stuttgart. 15 May 1867. HStAS.E40/72 Bü.442.

to Baron Karl Hugo von Spitzemberg. Stuttgart. 16 May 1867. HStAS.E40/72 Bü.442.

. Address to the 32nd Sitting of the German Reichstag. 28 April 1877. HStAS.P10 Bü.849.

Verfassung des Bundes der vereinigten Staaten Süddeutschlands. HStAS.E40/72 Bü.443.

Verhandlungen der Württembergischen Kammer der Abgeordneten auf dem Landtag. Ltg. 1862/65. Kammer der Abgeordneten. 83. Sitzung. 5.1.65.

Voltaire (Arouet, François-Marie), to Nicolas Claude Theriot. Chêne-Bourg. 26 October 1757. In Voltaire (Arouet, François-Marie.) Voltaire's Correspondence. Ed. Bestermann, Theodor. Vol.XXXII. Geneva. Institut et Musée Voltaire. 1958.

Oeuvres completes de Voltaire. Vol.XVIII. France. De l'imprimerie de la société littéraire. 1785.

. Voltaire's Correspondence. Ed. Bestermann, Theodor. Vol.XXXII. Geneva. Institut et Musée Voltaire. 1958.

Wächter, Baron August von, to Karl Ludwig Friedrich Roser. Karlsruhe. 8 April 1848. HStAS.E50/01 Bü.765.

to Baron Karl Eugen von Hügel. No.1466. Paris. 12 July 1859. HStAS.E50/01 Bü.875.

to Baron Friedrich Karl Gottlob Varnbüler von und zu Hemmingen. Paris. 15 April 1866. In Die Rheinpolitik Kaiser Napoleons III. von 1863 bis 1870 und der Ursprung des Krieges von 1870/71. Ed. Oncken, Hermann. 1.Bd.: 1863 bis Juli 1866. Stuttgart. Deutsche Verlags-Anstalt. 1926.

Wagner, Colonel, to Ministry of Foreign Affairs. No.638. 16 June 1866. HStAS.E271c Bü. 803.

“Die Wahl zur Ständeversammlung im Jahr 1819 (Oberamt Esslingen).” StadtAE. I/2 Bü.3.

Walter, Jakob. Diary of a Napoleonic Foot Soldier. New York. Penguin. 1993. 
Wangenheim, Karl August von. Die Idee der Staatsvefassung in ibrer Anwendung auf Wirtembergs alte Landesverfassung und den Entwurf zu deren Erneuerung. Frankfurt a.M. Bernard Körner. 1815.

, to Privy Councillor August von Hartmann. Coburg. 23 June 1831. In Riecke, Karl Viktor von. "Zur Vorgeschichte des Deutschen Zollvereins. Auszüge aus Briefen des Freiherrn K.A. v. Wangenheim." Württembergische Vierteljahrshefte für Landesgeschichte. 2 (1879): 101-111.

, to Privy Councillor August von Hartmann. Coburg. 30 August 1833. In Riecke, Karl Viktor von. "Zur Vorgeschichte des Deutschen Zollvereins. Auszüge aus Briefen des Freiherrn K.A. v. Wangenheim.” Württembergische Vierteljahrshefte für Landesgeschichte. 2 (1879): 101-111.

- Die Wabl des Freiherrn von Wangenheim, K. Würtembergischen Staatsministers ausser Dienst, zum Abgeordneten in die Würtembergische Ständeversammlung. Tübingen. Heinrich Laupp. 1832.

Weber, Karl Julius. Reise durch das Königreich Württemberg. Stuttgart. J.F. Steinkopf Verlag. 1978.

Wekherlin, Wilhelm Ludwig. Anselmus Rabiosus Reise durch Oberdeutschland. Salzburg. 1778.

Wellesley, Henry Richard Charles, Baron Cowley, to Henry John Temple, Viscount Palmerston. No.58. Stuttgart. 3 September 1834. In British Envoys to Germany, 1816-1866. Vol.II: 1830-1847. Eds. Mösslang, Markus, Freitag, Sabine and Wende, Peter. Cambridge. Cambridge University Press. 2002.

to George Hamilton-Gordon, Earl of Aberdeen. No.3. Stuttgart. 5 January 1843 . FO 82/42.

, to Henry John Temple, Viscount Palmerston. No.395. Frankfurt a.M. 14 November 1850. In British Envoys to Germany, 1816-1866. Vol.III: 1848-1850. Eds. Mösslang, Markus, Riotte, Torsten and Schulze, Hagen. Cambridge. Cambridge University Press. 2006.

Wendland, Baron August von, to Baron Karl Ludwig von der Pfordten. Paris. 1 July 1866. In Die Rheinpolitik Kaiser Napoleons III. von 1863 bis 1870 und der Ursprung des Krieges von 1870/71. Ed. Oncken, Hermann. 1.Bd.: 1863 bis Juli 1866. Stuttgart. Deutsche Verlags-Anstalt. 1926.

, to King Ludwig II. von Wittelsbach. Paris. 9 July 1866. In Die Rheinpolitik Kaiser Napoleons III. von 1863 bis 1870 und der Ursprung des Krieges von 1870/71. Ed. Oncken, Hermann. 1.Bd.: 1863 bis Juli 1866. Stuttgart. Deutsche Verlags-Anstalt. 1926. 
to King Ludwig II. von Wittelsbach. Paris. 14 July 1866. In Die Rheinpolitik Kaiser Napoleons III. von 1863 bis 1870 und der Ursprung des Krieges von 1870/71. Ed. Oncken, Hermann. 1.Bd.: 1863 bis Juli 1866. Stuttgart. Deutsche Verlags-Anstalt. 1926.

Wieland, Christoph Martin. "Über deutschen Patriotismus. Betrachtungen, Fragen und Zweifel” (originally published in May 1793). In Wieland, Christoph Martin. C.M. Wielands sämmtliche Werke. 31.Bd. Leipzig. Verlag von Georg Joachim Göschen. 1840.

. C.M. Wielands sämmtliche Werke. 31.Bd. Leipzig. Verlag von Georg Joachim Göschen. 1840.

Württemberg, Duke Ulrich von. "Tübinger Vertrag zwischen dem Herzog Ulrich von Württemberg als Landesherrn und den Prälaten und der Landschaft von Württemberg als Vetreter der Landstände.” Tübingen. 8 July 1514.

Württemberg, King Friedrich I. von, to Baron Heinrich Karl Friedrich Levin von Wintzingerode. Ludwigsburg. 10 May 1815. In Pfister, Albert. Aus dem Lager der Verbündeten 1814 und 1815. Stuttgart. Deutsche Verlags-Anstalt. 1897.

Württemberg, King Wilhelm I. von. "I. Edikt, mehrfache Änderungen im Abgabenwesen betreffend." Stuttgart. 18 November 1817. Königlich Württembergische Staats- und Regierungsblatt. 1817.

"Betrachtungen über die politisch-militärische Stellung von Süddeutschland.” November 1830. HStAS.E9 Nr.25.

Württemberg Consulate in Berlin. Disposition zur Manöver den 14. September 1821. Berlin. 14 September 1821. HStAS.E14 Bü.824.

Württemberg Consulate in Paris to King Wilhelm I. von Württemberg. État complet de linfanterie de la ligue française/Organisation de l'artillerie du la Garde Royale. No.2. 23 February 1819. HStAS.E70a Bü.537.

, to King Wilhelm I. von Württemberg. No.2. 23 February 1819. HStAS.E70a Bü.537.

, to King Wilhelm I. von Württemberg. Le Corps du génie ort compore d'un état major general, des trois regiments l'une compagnie d'ouvrier, et l'un escadrille du train du génie and Dernier Tarif pour les Réparations d'armée. 23 February 1819. HStAS.E70a Bü.537.

Württemberg Ministry of the Interior. "Wochenbericht." Stuttgart. 24 November 1851. In Der "Polizeiverein deutscher Staaten: Eine Dokumentation zur Überwachung der Öffentlichkeit nach der Revolution von 1848/49. Ed. Siemann, Wolfram. Tübingen. Max Niemeyer Verlag. 1983. 
Württemberg Ministry of War. "Aufruf an die Frauen und Jungfrauen." Stuttgart. 25 June 1866. HStAS.E271c Bü.848.

HStAS.E271c Bü.848.

Württembergische Jahrbücher für vaterländische Geschichte, Geographie, Statistik und Topographie. Stuttgart.Verlag von Karl Aue. 1862.

Württembergische Zeitung. Nr.30. 12 August 1849.

Wynn, Henry Watkin Williams, to Sir George Canning. No.4. Stuttgart. 3 June 1823. In British Envoys to Germany, 1816-1866. Vol.I: 1816-1829. Eds. Freitag, Sabine and Wende, Peter. Cambridge. Cambridge University Press. 2000.

, to Sir George Canning. No.6. Stuttgart. 9 June 1823. In British Envoys to Germany, 1816-1866. Vol.I: 1816-1829. Eds. Freitag, Sabine and Wende, Peter. Cambridge. Cambridge University Press. 2000.

, to Sir George Canning. No.22. Stuttgart. 18 June 1824. In British Envoys to Germany, 1816-1866. Vol.I: 1816-1829. Eds. Freitag, Sabine and Wende, Peter. Cambridge. Cambridge University Press. 2000.

, to Sir George Canning. No.11. Baden. 17 July 1823. In British Envoys to Germany, 1816-1866. Vol.I: 1816-1829. Eds. Freitag, Sabine and Wende, Peter. Cambridge. Cambridge University Press. 2000.

Zimmermann, Maria Agatha. Tagebuch. 17 November 1813. In Planert, Ute. "From Collaboration to Resistance: Politics, Experience, and Memory of the Revolutionary and Napoleonic Wars in Southern Germany." Central European History. 39, 4 (December 2006): 676-705. 


\section{SECONDARY SOURCES}

Aaslestad, Katherine and Hagemann, Karen. "1806 and its Aftermath: Revisiting the Period of the Napoleonic Wars in German Central European Historiography." Central European History. 39, 4 (December 2006): 547-579.

Anderson, Benedict. Imagined Communities: Reflections on the Origin and Spread of Nationalism. London. Verso. 2006.

Anderson, M.S. War and Society in Europe of the Old Regime, 1618-1789. Avon. Leicester University Press. 1988.

Applegate, Celia and Potter, Pamela. “The Germans as the 'People of Music': Genealogy of an Identity." In Music and German National Identity. Eds. Applegate, Celia and Potter, Pamela. Chicago. University of Chicago Press. 2002.

Aretin, Karl Otmar von. Das alte Reich. 3.Bd.: Das Reich und der österreichisch-preussische Dualismus (1745-1806). Stuttgart. Klett Cotta. 1997.

Austensen, Roy A. “Einheit oder Einigkeit?' Another Look at Metternich's View of the German Dilemma." German Studies Review. 6, 1 (February 1983): 41-57.

Baack, Lawrence J. Christian Bernstorff and Prussia: Diplomacy and Reform Conservatism, 1818-1832. New Brunswick. Rutgers University Press. 1980.

Barrett-Lennard, C.E. Bismarck's Pen: The Life of Heinrich Abeken. London. George Allen \& Company. 1911.

Beck, Marcel and Büttner, Heinrich. Die Bistümer Würzburg und Bamberg in ihrer wissenschaftlichen Bedeutung für die Geschichte des deutschen Osten. Berlin. Weidmannsche Verlagsbuchhandlung. 1937.

Bew, John. Castlereagh. Enlightenment, War and Tyranny, 1769-1822. London. Quereus. 2011.

Biefang, Andreas. Politisches Bürgertum in Deutschland 1857-1868. Nationale Organisationen und Eliten. Düsseldorf. Droste. 1994.

Billinger, Robert D. Jr. "The War Scare of 1831 and Prussian-South German Plans for the End of Austrian Dominance in Germany." Central European History. 9, 3 (September 1976): 203-219.

Blackbourn, David. The Long Nineteenth Century: A History of Germany, 1780-1918. New York. Oxford University Press. 1998.

Blanning, T.C.W. The Culture of Power and the Power of Culture: Old Regime Europe 1660-1789. Oxford. Oxford University Press. 2002. 
Blanning, Tim. The Pursuit of Glory: Europe 1648-1815. London. Penguin. 2008.

Blumberg, Arnold. "Russian Policy and the Franco-Austrian War of 1859." The Journal of Modern History. 26, 2 (June 1954): 137-153.

Boelcke, Willi A. "Wege und Probleme des industriellen Wachstums im Königreich Württemberg." Zeitschrift für Württembergische Landesgeschichte. 32 (1973): 436-520.

Boes, Maria. "Jews in the Criminal-Justice System of Early Modern Germany." The Journal of Interdisciplinary History. 30, 3 (Winter 2000): 407-435.

Böhme, Heinrich. Deutschlands Weg zur Großmacht: Studien zum Verhältnis von Wirtschaft und Staat während der Reichsgründungszeit 1848-1881. Cologne. Kiepenheuer \& Witsch. 1966.

Borden, Morton. "Friedrich Engels on Rifled Cannon." Part 1. Military Affairs. 21, 2 (Summer 1957): 75-78.

. "Friedrich Engels on Rifled Cannon." Part 2. Military Affairs. 21, 4 (Winter 1957): 193-198.

Borst, Otto. Stuttgart: Die Geschichte der Stadt. Stuttgart. Konrad Theiss Verlag. 1973. Verlag. 2004.

. Geschichte Baden-Württembergs: Ein Lesebuch. Stuttgart. Konrad Theiss

Bourgoing, Jean de. Vom Wiener Kongreß. Vienna. Herald. 1964.

Brandt, Harm-Hinrich. "The Revolution of 1848 and the Problem of Central European Nationalities." In Nation-Building in Central Europe. Ed. Schulze, Hagen. Leamington Spa. Berg. 1987.

Brandt, Hartwig. Parlamentarismus in Württemberg, 1819-1870: Anatomie eines deutschen Landtags. Düsseldorf. Droste. 1987.

Bremm, Klaus-Jürgen. Von der Chaussee zur Schiene: Militärstrategie und Eisenbahnen in Preussen von 1833 bis zum Feldzug von 1866. Munich. Oldenbourg Wissenschaftsverlag. 2005.

Breuilly, John. Nationalism and the State. Manchester. Manchester University Press. 1982.

Bringmann, Tobias C. Handbuch der Diplomatie 1815-1953: Auswärtige Missionschefs in Deutschland und deutsche Missionschefs im Ausland von Metternich bis Adenauer. Munich. K.G. Saur. 2001.

Brinkmann, Carl. "The Place of Germany in the Economic History of the Nineteenth Century." The Economic History Review. 4, 2 (April 1933): 129-146. 
Brose, Eric Dorn. German History, 1789-1871: From Holy Roman Empire to Bismarckian Reich. Providence. Berghahn. 1997.

Burg, Peter. Die Deutsche Trias in Idee und Wirklichkeit: vom Alten Reich zum Deutschen Zollverein. Stuttgart. Franz Steiner Verlag. 1989.

Burgdorf, Wolfgang. “'Reichsnationalismus' gegen 'Territorialnationalismus.” In Föderative Nation: Deutschlandkonzepte von der Reformation bis zum Ersten Weltkrieg. Eds. Langewiesche, Dieter and Schmidt, Georg. Munich. R. Oldenbourg Verlag. 2000.

Bußmann, Walter. Das Zeitalter Bismarcks Frankfurt am Main. Akademische Verlagsgesellschaft Athenaion. 1968.

- Zwischen Preußen und Deutschland. Friedrich Wilhelm IV.: eine Biographie. Berlin. Siedler. 1990.

The Campaigns of 1866 in Germany. London. Harrison and Sons. 1907.

Canevali, Ralph C. “The 'False French Alarm': Revolutionary Panic in Baden, 1848." Central European History. 18, 2 (June 1985): 119-142.

Carr, W. Schleswig-Holstein 1815-48: A Study in National Conflict. Manchester. Manchester University Press. 1963.

Chandler, David G. The Campaigns of Napoleon. New York. MacMillan. 1966.

Churchill, Winston S. The Second World War. Vol.V: Closing the Ring. London. Houghton Mifflin Harcourt. 1985.

Clark, Christopher. Iron Kingdom: The Rise and Downfall of Prussia 1600-1947. London. Penguin. 2007.

. "Diener auf dem Thron." In Preussen: Die unbekannte Großmacht. Eds. Burgdorff, Stephan, Pötzl, Norbert F. and Wiegrefe, Klaus. Munich/Hamburg. Deutsche Verlags-Anstalt/Spiegel-Verlag. 2008.

C.L.K. "German Art of the Eighteenth Century." Germanic Museum Bulletin. 1, 2 (March 1936): 8-12.

Confino, Alon. The Nation as a Local Metaphor: Württemberg, Imperial Germany, and National Memory, 1871-1918. Chapel Hill. University of North Carolina Press. 1997.

Corti, Egon Caesar Conte. The Downfall of Three Dynasties. Freeport. Books for Libraries Press. 1970. 
Cusack, Andrew. “'Der schein ist gegen sie': Physiognomy and Honour in Schiller's 'Der Verbrecher aus verlorener Ehre.” The Modern Language Review. 101, 3 (July 2006): $759-773$.

Dahrendorf, Ralf. Society and Democracy in Germany. London. Weidenfeld \& Nicolson. 1968.

Döberl, Michael. Bayern und die deutsche Erbebung wider Napoleon I. Munich. Verlag der Königlich Bayerischen Akademie der Wissenschaft. 1907.

Doering-Manteuffel, Anselm. Die Deutsche Frage und das europäische Staatensystem 1815-1871. Munich. R. Oldenbourg Verlag. 2001.

Dorpalen, Andreas. “The German Struggle against Napoleon: The East German View." The Journal of Modern History. 41, 4 (December 1969): 485-516.

Duggan, Christopher. The Force of Destiny: A History of Italy since 1796. London. Allen Lane. 2007.

Dumas, Samuel. Losses of Life Caused by War. Oxford. Clarendon Press. 1923.

Echternkamp, Jörg. Der Aufstieg des deutschen Nationalismus (1770-1840). Frankfurt a.M. and New York. Campus Verlag. 1998.

Eichner, Barbara. History in Mighty Sounds: Musical Constructions of German National Identity 1848-1914. Woodbridge. Boydell Press. 2012.

Ellis, Geoffrey. "The Revolution of 1848-1849 in France." In The Revolutions in Europe 1848-1849: From Reform to Reaction. Eds. Evans, R.J.W. and Pogge von Strandmann, Hartmut. Oxford. Oxford University Press. 2002.

Elting, John R. Swords around a Throne: Napoleon's Grand Armée. New York. Da Capo. 1997.

Enlightened Absolutism: Reform and Reformers in Later Eighteenth-Century Europe. Ed. Scott, H.M. Houndsmill. Macmillan. 1990.

Ergang, Robert R. "Möser and the Rise of National Thought in Germany." The Journal of Modern History. 5, 2 (June 1933): 172-196.

Ethnicity. Eds. Hutchinson, John and Smith, Anthony D. Oxford. Oxford University Press. 1996.

Evans, Richard J. Death in Hamburg: Society and Politics in the Cholera Years 1830-1910. Oxford. Clarendon Press. 1987. 
- "The 'Dangerous Classes' in Germany from the Middle Ages to the Twentieth Century." In The German Underworld: Deviants and Outcasts in German History. Ed. Evans, Richard J. London. Routledge. 1988.

Evans, R.J.W. "1848-1849 in the Habsburg Monarchy." In The Revolutions in Europe 1848-1849: From Reform to Reaction. Eds. Evans, R.J.W. and Pogge von Strandmann, Hartmut. Oxford. Oxford University Press. 2002.

Evera, Stephen van. "Offense, Defense, and the Causes of War." International Security. 22, 4 (Spring 1988): 5-43.

Eyck, F. Gunther. "The Political Theories and Activities of the German Academic Youth between 1815 and 1819.” The Journal of Modern History. 27, 1 (March 1995): 27-38.

Fisher, H.A.L. A History of Europe. London. Edward Arnold \& Co. 1949.

Flenley, Ralph. Modern German History. London. J.M. Dent \& Sons. 1959.

Flik, Reiner. Die Textilindustrie in Calw und Heidenheim 1750-1870. Stuttgart. Franz Steiner Verlag. 1990.

Flockerzie, Lawrence J. “Saxony, Austria, and the German Question after the Congress of Vienna, 1815-1816.” The International History Review. 12, 4 (November 1990): 661-687.

. "State-Building and Nation-Building in the 'Third Germany': Saxony after the Congress of Vienna." Central European History. 24, 3 (1991): 268-292.

Föderative Nation: Deutschlandkonzepte von der Reformation bis zum Ersten Weltkrieg. Eds. Langewiesche, Dieter and Schmidt, Georg. Munich. R. Oldenbourg Verlag. 2000.

Folliot-Crenneville, Karl. Die österreichische Nordarmee und ihr Führer in Jahre 1866. Vienna. Wilhelm Braumüller. 1906.

Frevert, Ute. A Nation in Barracks: Modern Germany, Military Conscription and Civil Society. Oxford. Berg. 2004.

Friedjung, Heinrich. Der Kampf um die Vorherrschaft in Deutschland. 2.Bd. Stuttgart. J.G. Cotta'sche Buchhandlung. 1917.

Fuchs, Walther Peter. Die deutschen Mittelstaaten und die Bundesreform 1853-1860. Berlin. Ebering. 1934.

Gall, Lothar. Der Liberalismus als regierende Partei. Wiesbaden. F. Steiner. 1968.

. Bismarck. Vol.1. London. Allen \& Unwin. 1986.

Gates, David. The Napoleonic Wars 1803-1815. London. Arnold. 1997. 
Gerber, Hans. "König Wilhelm I. von Württemberg als Bauherr und Regent - Zum 150. Todestag des Hofbaumeisters Giovanni Salucci.” Schwäbische Heimat. 46, 3 (1995): 228-245.

The German Underworld: Deviants and Outcasts in German History. Ed. Evans, Richard J. London. Routledge. 1988.

Gierowski, Józef Andrzej. "Centralisation and Autonomy in the Polish-Saxon Union." Harvard Ukrainian Studies. 3/4 (1979/1980): 271-284.

Ginsborg, Paul. Daniele Manin and the Venetian Revolution of 1848-49. Cambridge. Cambridge University Press. 1979.

Görtemaker, Manfred. Deutschland im 19. Jahrhundert: Entwicklungslinien. Bonn. Leske Verlag + Budrich. 1983.

Gramit, David. Cultivating Music: The Aspirations, Interests, and Limits of German Musical Culture, 1770-1848. Berkeley. University of California Press. 2002.

Graubard, Stephen R. "Castlereagh and the Peace of Europe." The Journal of British Studies. 3, 1 (November 1963): 79-87.

Grauer, Karl Johannes. Wilhelm I., König von Württemberg: Ein Bild seines Lebens und seiner Zeit. Stuttgart. Schwabenverlag. 1960.

Green, Abigail. Fatherlands: State-building and Nationhood in Nineteenth-Century Germany. Cambridge. Cambridge University Press. 2001.

. "The Federal Alternative? A New View of Modern German History." The Historical Journal. 46, 1 (March 2003): 187-202.

. "Representing Germany? The Zollverein at the World Exhibitions, 1851-1862." The Journal of Modern History. 75, 4 (December 2003): 836-863.

Grube, Walter. Der Stuttgarter Landtag 1457-1957. Von den Landständen zum demokratischen Parlament. Stuttgart. Ernst Klett Verlag. 1957.

Gunlicks, Arthur B. "Authoritative Centralisation and Decentralisation in the Making and Remaking of Modern Germany." The Review of Politics. 46, 3 (July 1984), 323-345.

Hahn, Hans-Werner. Wirtschaftliche Integration im 19. Jahrhundert: Die hessischen Staaten und der Deutsche Zollverein. Göttingen. Vandenhoeck \& Ruprecht. 1982.

- Geschichte des Deutschen Zollverein. Göttingen. Vandenhoeck \& Ruprecht. 1984.

Hagel, Jürgen. Stuttgart im Spiegel alter Karten und Pläne. Stuttgart. Katalog der Ausstellung des Hauptstaatsarchivs Stuttgart. 1984. 
Hamerow, Theodore S. The Social Foundations of German Unification, 1858-1871. Vol.I: Ideas and Institutions. Princeton. Princeton University Press. 1969. - The Social Foundations of German Unification, 1858-1871. Vol.II: Struggles and Accomplishments. Princeton. Princeton University Press. 1972.

Handbuch der preussischen Geschichte. Ed. Büsch, Otto. 2.Bd. Berlin. De Gruyter. 1992.

Hanisch, Manfred. Für Fürst und Vaterland. Legitimätsstiftung in Bayern zwischen Revolution 1848 und deutscher Einheit. Munich. Oldenbourg. 1991.

Harder, Hans-Joachim. Militärgeschichtliches Handbuch Baden-Württembergs. Stuttgart. Kohlhammer. 1987.

Hartmann, Julius. Chronik der Stadt Stuttgart: 600 Jahre nach der ersten denkwürdigen Nennung der Stadt (1286). Stuttgart. Greiner \& Pfeiffer. 1886.

Heinzelmann, J.H. "Pope in Germany in the Eighteenth Century." Modern Philology. 10, 3 (January 1913): 317-364.

Hellwag, Fritz. Varnbüler und die deutsche Frage 1864-1866. Stuttgart. Kohlhammer, 1934.

Henderson, W.O. The Zollverein. London. Frank Cass. 1984.

Hentschel, Volker. Wirtschaftsgeschichte der Maschinenfabrik Esslingen AG 1846-1918. Eine historisch-betriebswirtschaftliche Analyse. Stuttgart. Ernst Klett Verlag. 1977.

Hettling, Manfred. Reform ohne Revolution: Bürgertum, Bürokratie und kommunale Selbstverwaltung in Württemberg von 1800 bis 1850. Göttingen. Vandenhoeck \& Ruprecht. 1990.

Hobsbawm, E.J. Nations and Nationalism since 1780: Programme, Myth, Reality. Cambridge. Cambridge University Press. 2004.

Hoffmann, Peter. Die diplomatische Beziehungen zwischen Württemberg und Bayern im Krimkrieg und bis zum Beginn der italienischen Krise 1853-1858. Stuttgart. W. Kohlhammer. 1963.

Holborn, Hajo. A History of Modern Germany 1648-1840. New York. Alfred A. Knopf. 1967.

Hölzle, Erwin. “Das Napoleonische Staatssystem in Deutschland.” Historische Zeitschrift. 148, 2 (1933): 277-293.

Hoover, A.J. The Gospel of Nationalism: German Patriotic Preaching from Napoleon to Versailles, 1806-1918. Stuttgart. Franz Steiner. 1986. 
Hope, Nicholas Martin. The Alternative to German Unification: The Anti-Prussian Party: Frankfurt, Nassau, and the Two Hessen, 1859-1867. Wiesbaden. F. Steiner. 1973.

Horn, D.B. "Saxony in the War of the Austrian Succession." The English Historical Review. 44, 173 (January 1929): 33-47.

Howard, Michael. The Franco-Prussian War: The German Invasion of France, 1870-1871. London. Routledge. 2008.

Hughes, Michael. Nationalism and Society: Germany 1800-1945. London. Edward Arnold. 1991.

Ingrao, Charles. "The Smaller German States." In Enlightened Absolutism: Reform and Reformers in Later Eighteenth-Century Europe. Ed. Scott, H.M. Houndsmill. Macmillan. 1990.

Kann, Robert A. A History of the Habsburg Empire 1526-1918. Berkeley. University of California Press. 1974.

Kershaw, Ian. Popular Opinion and Political Dissent in the Third Reich: Bavaria, 1933-1945. Oxford. Oxford University Press. 2002.

Kiernan, V.G. "Foreign Mercenaries and Absolute Monarchy." Past \& Present. 11 (April 1957): 66-86.

Kiesewetter, Hubert. Industrialisierung und Landwirtschaft: Sachsens Stellung im regionalen Industrialisierungsprozess Deutschlands im 19. Jahrhundert. Cologne. Böhlau. 1988.

Kirsch, Ludwig. Die Zoll- und Reichssteuerverwaltungen im Großherzogthum Baden. Karlsruhe. Braun. 1885.

Kissinger, Henry A. “The Congress of Vienna: A Reappraisal.” World Politics. 8, 2 (January 1956): 264-280.

Kitchen, Martin. “Friedrich Engels' Theory of War." Military Affairs. 41, 3 (October 1977): 119-124.

Kluge, Cora Lee. “Through the Biographical Lens: Schiller and the Ladies.” Monatshefte. 97, 3 (Fall 2005): 450-460.

Koberstädt, Albrecht. "Energieprobleme im Oberamt Heidenheim. Ein Beitrag zur Wirtschafts- und Sozialgeschichte der Region Ostalb." Schwäbisch Hall. Ph.D. diss. 1980.

Köhler, Jutta. Friedrich Römer als Politiker. Stuttgart. W. Kohlhammer. 1929.

Kohn, Hans. "Arndt and the Character of German Nationalism." The American Historical Review, 54, 4 (July 1949): 787-803. 
. "Romanticism and the Rise of German Nationalism." The Review of Politics. 12, 4 (October 1950): 443-472.

. The Mind of Germany: The Education of a Nation. New York. Scribner.

1960.

Kollmer-von Oheimb-Loup, Gert. Innovation und Zollverein. Die Reaktion württembergischer Textilindustrieller auf den Deutschen Zollverein 1834-1874. St. Katharinen. Scripta Mercaturae Verlag. 1996.

Kraehe, Enno E. Metternich's German Policy. Vol.1: The Contest with Napoleon, 1799-1814. Princeton. Princeton University Press. 1963.

Kühlmann, Wilhelm. "Sprachgesellschaften und nationale Utopien." In Föderative Nation: Deutschlandkonzepte von der Reformation bis zum Ersten Weltkrieg. Eds. Langewiesche, Dieter and Schmidt, Georg. Munich. R. Oldenbourg Verlag. 2000.

Langewiesche, Dieter. Liberalismus und Demokratie in Württemberg zwischen Revolution und Reichsgründung. Düsseldorf. Droste-Verlag. 1974.

. Liberalism in Germany. London. Macmillan. 2000.

Lee, Loyd E. "Liberal Constitutionalism as Administrative Reform: The Baden Constitution of 1818." Central European History. 8, 2 (June 1975): 91-112.

"Baden between Revolutions: State-Building and Citizenship, 1800-1848." Central European History. 24, 3 (1991): 248-267.

Lincoln, W. Bruce. "Reform and Reaction in Russia: A.V. Golovnin's Critique of the 1860s." Cahiers du Monde russe et soviétique. 16, 2 (April - June 1975): 167-179.

Lutz, Rolland Ray. “The German Revolutionary Student Movement, 1819-1833.” Central European History. 4, 3 (September 1971): 215-241.

. "'Father' Jahn and his Teacher-Revolutionaries from the German Student Movement." The Journal of Modern History. 48, 2 (June 1976): 1-34.

Macartney, C.A. The Habsburg and Hohenzollern Dynasties in the Seventeenth and Eighteenth Centuries. New York. Harper \& Row. 1970.

Malleson, G.B. The Refounding of the German Empire, 1848-1871. London. Seeley \& Co. 1904.

Mann, Bernhard. Die Württemberger und die deutsche Nationalversammlung 1848/49. Düsseldorf. Droste Verlag. 1975.

. Kleine Geschichte des Königreichs Württemberg 1806-1918. LeinfeldenEchterdingen. DRW-Verlag. 2006. 
Mann, Golo. Deutsche Geschichte des 19. und 20. Jahrhunderts. Frankfurt am Main. Büchergilde Gutenberg. 1958.

Mästle, Theodor. "Württemberg und die Großmächte vom Wiener Kongreß bis zum Tode König Wilhelms I. (1815-1864).” Tübingen. Ph.D diss. 1951.

Medick, Hans. “The So-Called 'Laichingen Hunger Chronicle”. History Workshop Journal. 40 (Autumn 1995): 207-219.

. Weben und Überleben in Laichingen 1650-1900: Lokalgeschichte als Allgemeine Geschichte. Göttingen. Vandenhoeck \& Ruprecht. 1997.

Megerle, Klaus. Württemberg im Industrialisierungsprozeß Deutschlands: Ein Beitrag zur regionalen Differenzierung der Industrialisierung. Stuttgart. Klett-Cotta. 1982.

- "Ökonomische Integration und politische Orientierung deutscher Mittel- und Kleinstaaten im Vorfeld der Reichsgründung." Geschichte und Gesellschaft. Sonderheft. 10, Wirtschaftliche und politische Integration in Europa im 19. und 20. Jahrhundert. (1984): 102-127.

Mehring, Franz. “1813 bis 1819. Von Kalisch nach Karlsbad.” In Mehring, Franz. Aufsätze zur preußischen und deutschen Geschichte. Leipzig. Reclam. 1986. Aufsätze zur preußischen und deutschen Geschichte. Leipzig. Reclam. 1986.

Meinecke, Friedrich. Das Leben des Generalfeldmarchalls Hermann von Boyen. 2.Bd. Stuttgart. J.G. Cotta. 1899.

Menk, Gerhard. Die Hohe Schule Herborn in ihrer Frübzeit, 1584-1660: Ein Beitrag zum Hochschulwesen des deutschen Kalvinismus im Zeitalter der Gegenreformation. Wiesbaden. Historische Kommission für Nassau. 1981.

Mitchell, Allan. The Great Train Race: Railways and the Franco-German Rivalry 1815-1914. New York. Berghahn. 2000.

Mommsen, Wolfgang J. Das Ringen um den nationalen Staat: Die Gründung und der innere Ausbau des Deutschen Reiches unter Otto von Bismarck 1850-1890. Berlin. Propyläen Verlag. 1993.

Murdock, Caitlin E. “Tourist Landscapes and Regional Identities in Saxony, 1878-1938.” Central European History. 40, 4 (December 2007): 589-621.

Music and German National Identity. Eds. Applegate, Celia and Porter, Pamela. Chicago University of Chicago Press. 2002. 
Nanninga, Folkert. 'Zur 'deutschen' Politik des württembergischen Außenministers von Varnbüler in den Jahren 1864 bis 1870." Zeitschrift für Württembergische Landesgeschichte. 32 (1973): 113-149.

Nation-Building in Central Europe. Ed. Schulze, Hagen. Leamington Spa. Berg. 1987.

Naujoks, Eberhard. "Württemberg im diplomatischen Kräftespiel der Reichsgrüngungszeit (1866/70). Zur Problematik der deutschen Politik des Freiherrn von Varnbüler." Zeitschrift für Württembergische Landesgeschichte. 30 (1971): 201-240.

Neugebauer-Wölk, Monika. Revolution und Constitution. Die Brüder Cotta: Eine biographische Studie zum Zeitalter der Französischen Revolution und des Vormärz. Berlin. Siedler. 1989.

Nicholson, J. Shield. "Memoir." In List, Friedrich. The National System of Political Economy. Ed. Lloyd, Sampson S. London. Longmans, Green and Co. 1909.

Nipperdey, Thomas. "Probleme der Modernisierung in Deutschland." Saeculum. 30 (1979): 292-303.

. Deutsche Geschichte 1800-1866. 1.Bd.: Bürgerwelt und starker Staat. Munich. C.H. Beck. 1998.

. Deutsche Geschichte 1866-1918. 1.Bd.: Arbeitswelt und Bürgergeist. Munich. C.H. Beck. 1998.

. Deutsche Geschichte 1866-1918. 2.Bd.: Machtstaat vor der Demokratie. Munich. C.H. Beck. 1998.

Nyhus, Paul L. "The Franciscans in South Germany, 1400-1530: Reform and Revolution.” Transactions of the American Philosophical Society. New Series. 65, 8 (1975): 1-47.

Ohff, Heinz. Preußens Könige. Munich. Piper Verlag. 1999.

The Oxford Handbook of Modern German History. Ed. Smith, Helmut Walser. Oxford. Oxford University Press. 2011.

Ozment, Steven. A Mighty Fortress: A New History of the German People, 100 B.C. to the 21st Century. London. Granta. 2005.

Pflanze, Otto. Bismarck and the Development of Germany. Vol.I: The Period of Unification, 1815-1871. Princeton. Princeton University Press. 1990.

Pierenkemper, Toni, and Tilly, Richard. The German Economy in the Nineteenth Century. New York. Berghahn. 2005.

Pinson, Koppel S. Modern Germany: Its History and Civilisation. New York. Macmillan. 1961. 
Planert, Ute. "From Collaboration to Resistance: Politics, Experience, and Memory of the Revolutionary and Napoleonic Wars in Southern Germany." Central European History. 39, 4 (December 2006): 676-705.

Der Polizeiverein deutscher Staaten: Eine Dokumentation zur Überwachung der Öffentlichkeit nach der Revolution von 1848/49. Ed. Siemann, Wolfram. Tübingen. Max Niemeyer Verlag. 1983.

Poschinger, Heinrich von. Fürst Bismarck und die Parlamentarier. 3.Bd. Breslau. E. Trewendt. 1892.

Preussen: Die unbekannte Großmacht. Eds. Burgdorff, Stephan, Pötzl, Norbert F. and Wiegrefe, Klaus. Munich/Hamburg. Deutsche Verlags-Anstalt/Spiegel-Verlag. 2008.

Rabe, Sigurd. Das Zündnadelgewehr greift ein. Leipzig. Lühe. 1938.

Raberg, Frank. Biographisches Handbuch der württembergischen Landtagsabgeordneten 1815-1933. Stuttgart. W. Kohlhammer Verlag. 2001.

Rapp, Adolf. Die Württemberger und die nationale Frage 1863-1871. Stuttgart. W. Kohlhammer. 1910.

Rapport, Mike. 1848: Year of Revolution. London. Little, Brown. 2008.

Rauch, Moriz von. "Salz- und Weinhandel zwischen Bayern und Württemberg im 18. Jahrhundert." Württembergische Vierteljahrshefte für Landesgeschichte. 33 (1927): 208-250.

Real, Willy. Der Deutsche Reformverein. Großdeutsche Stimmen und Kräfte zwischen Villafranca und Königgrätz. Lübeck. Matthiesen. 1966.

Reiffenstein, Ingo. "Deutsch in Österreich vom 18. bis ins 20. Jahrhundert: Das problematische Verhältnis von Sprache und Nation." In Föderative Nation: Deutschlandkonzepte von der Reformation bis zum Ersten Weltkrieg. Eds. Langewiesche, Dieter and Schmidt, Georg. Munich. R. Oldenbourg Verlag. 2000.

Renzsch, Wolfgang. "German Federalism in Historical Perspective: Federalism as a Substitute for a National State." Publius. 19, 4, Federalism and Intergovernmental Relations in West Germany: A Fortieth Year Appraisal (Autumn 1989): 17-33.

The Revolutions in Europe 1848-1849: From Reform to Reaction. Eds. Evans, R.J.W. and Pogge von Strandmann, Hartmut. Oxford. Oxford University Press. 2002.

Rohr, Donald G. The Origins of Social Liberalism in Germany. Chicago. University of Chicago Press. 1963.

Roscher, Wilhelm. Zur Gründungsgeschichte des Zollvereins. Berlin. Stilke \& van Muyden. 1870. 
Ross, Ronald J. "Heinrich Ritter von Srbik and 'Gesamtdeutsch' History." The Review of Politics. 31, 1 (January 1969): 88-107.

Runge, Gerlinde. Die Volkspartei in Württemberg von 1864 bis 1871. Die Erben der 48er Revolution im Kampf gegen die preussischkleindeutsche Lösung der nationalen Frage. Stuttgart. W. Kohlhammer. 1970.

Sabean, David Warren. Property, Production, and Family in Neckarhausen, 1700-1870. Cambridge. Cambridge University Press. 1990.

Sauer, Paul. "Die Neuorganisation des württembergischen Heerwesens unter Herzog, Kurfürst und König Friedrich (1797-1816)." Zeitschrift für Württembergische Landesgeschichte. 26 (1967): 395-420.

. Baden-Württemberg: Bundesland mit parlamentarischen Traditionen. Stuttgart. Landtag des Bundeslands Baden-Württemberg. 1982.

Der schwäbische Zar: Friedrich, Württembergs erster König. Stuttgart. Deutsche Verlags-Anstalt. 1984.

. “Stuttgart um 1840." In Württemberg um 1840. Beiträge zum 150jährigen Bestehen des Württembergischen Geschichts- und Altertumsvereins. Ed. Maurer, Hans-Martin. Stuttgart. W. Kohlhammer Verlag. 1994.

Reformer auf dem Königsthron: Wilhelm I. von Württemberg. Stuttgart. Deutsche Verlags-Anstalt. 1997.

Regent mit mildem Zepter: König Karl von Württemberg. Stuttgart. Deutsche Verlags-Anstalt. 1999.

Schmitt, Hans A. "Prussia's Last Fling: The Annexation of Hanover, Hesse, Frankfurt, and Nassau, June 15 - October 8, 1866." Central European History. 8, 4 (December 1975): 316-347.

. "Germany without Prussia: A Closer Look at the Confederation of the Rhine.” German Studies Review. 6, 1 (February 1983): 9-39.

Schroeder, Paul W. "An Unnatural 'Natural Alliance': Castlereagh, Metternich, and Aberdeen in 1813." The International History Review. 10, 4 (November 1988): 522-540.

Schulz, Matthias. "A Balancing Act: Domestic Pressures and International Systemic Constraints in the Foreign Policies of the Great Powers, 1848-1851." German History. 21, 3 (July 2003): 319-346.

Schulze, Hagen. "The Revolution of the European Order and the Rise of German Nationalism." In Nation-Building in Central Europe. Ed. Schulze, Hagen. Leamington Spa. Berg. 1987. 
Scirocco, Alfonso. Garibaldi: Citizen of the World. Princeton. Princeton University Press. 2007.

Scott, H.M. "Reform in the Habsburg Monarchy 1740-1790." In Enlightened Absolutism: Reform and Reformers in Later Eighteenth-Century Europe. Ed. Scott, H.M. Houndsmill. Macmillan. 1990.

Seeley, John R. Life and Times of Stein, or, Germany and Prussia in the Napoleonic Age. 3 Vols. Cambridge. University Press. 1878.

Sheehan, James J. German Liberalism in the Nineteenth Century. Chicago. University of Chicago Press. 1978.

- "What is German History? Reflections on the Role of the Nation in German History and Historiography." The Journal of Modern History. 53, 1 (March 1981): 1-23.

. German History 1770-1866. Oxford. Clarendon Press. 1989.

Showalter, Dennis E. "Diplomacy and the Military in France and Prussia, 1870." Central European History. 4, 4 (December 1971): 346-353.

. Railroads and Rifles: Soldiers, Technology and the Unification of Germany. St Petersburg. Hailer. 1975.

Siedentop, Uwe. Die Brenztalbahn. Heidenheim. Verlag Uwe Siedentop. 1984.

Siemann, Wolfram. "Deutschlands Ruhe, Sicherheit und Ordnung": Die Anfänge der politischen Polizei 1806-1866. Tübingen. Max Niemeyer Verlag. 1985.

Simms, Brendan. The Struggle for Mastery in Germany, 1779-1850. London. Palgrave Macmillan. 1998. Lane. 2013.

. Europe: The Struggle for Supremacy 1453 to the Present. London. Allen

Simon, Walter M. "Prince Hardenberg." The Review of Politics. 18, 1 (January 1956): 88-99.

Sked, Alan. The Survival of the Habsburg Empire: Radetzky, the Imperial Army and the Class War, 1848. London. Longman. 1979.

Smith, Anthony D. The Ethnic Origins of Nations. Oxford. Basil Blackwell. 1988.

Smith, Denis Mack. "The Revolutions of 1848-1849 in Italy." In The Revolutions in Europe 1848-1849: From Reform to Reaction. Eds. Evans, R.J.W. and Pogge von Strandmann, Hartmut. Oxford. Oxford University Press. 2002. 
Smith, Helmut Walser. "Authoritarian State, Dynamic Society, Failed Imperialist Power, 1878-1914." In The Oxford Handbook of Modern German History. Ed. Smith, Helmut Walser. Oxford. Oxford University Press. 2011.

Snyder, Louis L. German Nationalism. The Tragedy of a People: Extremism contra Liberalism in Modern German History. Harrisburg. Stackpole. 1952.

1978.

. Roots of German Nationalism. Bloomington. Indiana University Press.

Sofka, James R. "Metternich's Theory of European Order: A Political Agenda for 'Perpetual Peace." The Review of Politics. 60, 1, (Winter 1998): 115-149.

Sondhaus, Lawrence. "Schwarzenberg, Austria, and the German Question, 1848-1851." The International History Review. 13, 1 (February 1991): 1-20.

Sperber, Jonathan. "Echoes of the French Revolution in the Rhineland, 1830-1849." Central European History. 22, 2 (June 1989): 200-217.

Speitkampf, Winfried. "Staat und Bildung in Deutschland unter dem Einfluß der Französischen Revolution.” Historische Zeitschrift. 250, 3 (June 1990): 549-578.

Srbik, Heinrich Ritter von. Deutsche Einheit: Idee und Wirklichkeit vom Heiligen Reich bis Königgrätz. 1.Bd. Munich. 1935.

- Deutsche Einheit: Idee und Wirklichkeit vom Heiligen Reich bis Königgrätz. 2.Bd. Munich. 1935.

- Deutsche Einheit: Idee und Wirklichkeit vom Heiligen Reich bis Königgrätz. 3.Bd. Munich. 1935.

Stamm-Kuhlmann, Thomas. König in Preußens große Zeit: Friedrich Wilhelm III., der Melancholiker auf dem Thron. Berlin. Siedler. 1992.

Steinberg, Jonathan. Bismarck: A Life. Oxford. Oxford University Press. 2011.

Steinberg, S.H. A Short History of Germany. Cambridge. Cambridge University Press. 1945.

Sterne, Margaret. "The End of the Free City of Frankfort." Journal of Modern History. 30, 3 (September 1958): 203-214.

Strauss, Gerald. "The Holy Roman Empire Revisited.” Central European History. 11, 3 (September 1978): 290-301.

Struckmann, Johann Caspar and Henning, Eckart. Preußische Diplomaten im 19. Jahrhundert: Biographien und Stellenbesetzungen der Auslandsposten 1815-1870. Berlin. Trafo. 2003. 
Sybel, Heinrich von. The Founding of the German Empire by William I, Based Chiefly Upon Prussian State Documents. 5 Vols. New York. Thomas Y. Crowell \& Co. 1890-1898.

Taylor, A.J.P. The Course of German History: A Survey of the Development of German History since 1815. London. Routledge. 2008.

Tilly, Richard. "Popular Disorders in Nineteenth-Century Germany: A Preliminary Survey." Journal of Social History. 4, 1 (Autumn 1970): 1-40.

Treitschke, Heinrich von. Historische und Politische Aufsätze. 3 Vols. Leipzig. S. Hirzel. 1886-1897.

. History of Germany in the 19th Century. Vol.2: The Germanic Federation. London. G. Allen \& Unwin. 1916.

. Deutsche Geschichte im neunzehnten Jabrhundert. 1.Bd.: Zusammenbruch und nationale Erhebung. Leipzig. Alfred Kröner Verlag. 1934.

. Deutsche Geschichte im neunzehnten Jahrhundert. 2.Bd.: Staat und Kultur der Friedenszeit. Leipzig. Alfred Kröner Verlag. 1934.

Treue, Wilhelm. Wirtschafts- und Technikgeschichte Preußens. Berlin. Walter de Gruyter. 1984.

Ulbricht, Otto. “Infanticide in Eighteenth Century Germany.” In The German Underworld: Deviants and Outcasts in German History. Ed. Evans, Richard J. London. Routledge. 1988.

Vann, James Allen. The Making of a State: Württemberg 1593-1793. Ithaca. Cornell University Press. 1984.

Veit-Brause, Irmline. "Local and National Elites in the German Empire: The Case of the Württemberg Varnbülers." German Politics \& Society. 19, 3 (Fall 2001): 34-55.

Vick, Brian. "The Origins of the German Volk: Cultural Purity and National Identity in Nineteenth-Century Germany." German Studies Review. 26, 2 (May 2003): 241-256.

Viereck, Peter. "New Views on Metternich." The Review of Politics. 13, 2 (April 1951): 211-228.

Wagner, Adolph. "The National Debt of the German Empire." The North American Review. 174, 547 (June 1902): 845-856.

Watson, Peter. The German Genius: Europe's Third Renaissance, the Second Scientific Revolution, and the Twentieth Century. New York. Harper. 2010. 
Wawro, Geoffrey. "An 'Army of Pigs': The Technical, Social, and Political Bases of Austrian Shock Tactics, 1859-1866." The Journal of Military History. 59, 3 (July 1995): 407-433.

. The Austro-Prussian War: Austria's War with Prussia and Italy in 1866. Cambridge. Cambridge University Press. 2007.

. The Franco-Prussian War: The German Conquest of France in 1870-1871. Cambridge. Cambridge University Press. 2008.

Wehler, Hans-Ulrich. "Nationalismus ohne Nation? Ein anspruchsvoller, aber mißglückter Versuch.” Die Zeit. 9 December 1983.

- Deutsche Gesellschaftsgeschichte. 2.Bd.: Von der Reformära bis zur industriellen und politischen "Deutschen Doppelrevolution", 1815-1845/49. Munich: Verlag C.H. Beck. 1989.

Weidner, Karl. Die Anfänge einer staatlichen Wirtschaftspolitik in Württemberg. Stuttgart. Kohlhammer. 1931.

Weller, Karl. Württembergische Geschichte. Stuttgart. Silberburg-Verlag. 1957.

Whaley, Joachim. Germany and the Holy Roman Empire. Vol.I: Maximilian I to the Peace of Westphalia 1493-1648. Oxford. Oxford University Press. 2013.

. Germany and the Holy Roman Empire. Vol.II: The Peace of Westphalia to the Dissolution of the Reich 1648-1806. Oxford. Oxford University Press. 2013.

Wiegrefe, Klaus. "Ein Staat von Blut und Eisen." In Preussen: Die unbekannte Großmacht. Eds. Burgdorff, Stephan, Pötzl, Norbert F. and Wiegrefe, Klaus. Munich/Hamburg. Deutsche Verlags-Anstalt/Spiegel-Verlag. 2008.

Wilson, Peter H. The Thirty Years War: Europe's Tragedy. Cambridge, Massachusetts. Belknap Press. 2009.

Windell, George G. The Catholics and German Unity, 1866-1871. Minneapolis. University of Minnesota Press. 1954.

Württemberg um 1840. Beiträge zum 150jährigen Bestehen des Württembergischen Geschichts- und Altertumsvereins. Ed. Maurer, Hans-Martin. Stuttgart. W. Kohlhammer Verlag. 1994.

Zamoyski, Adam. Rites of Peace: The Fall of Napoleon and the Congress of Vienna. New York. HarperCollins. 2007. 